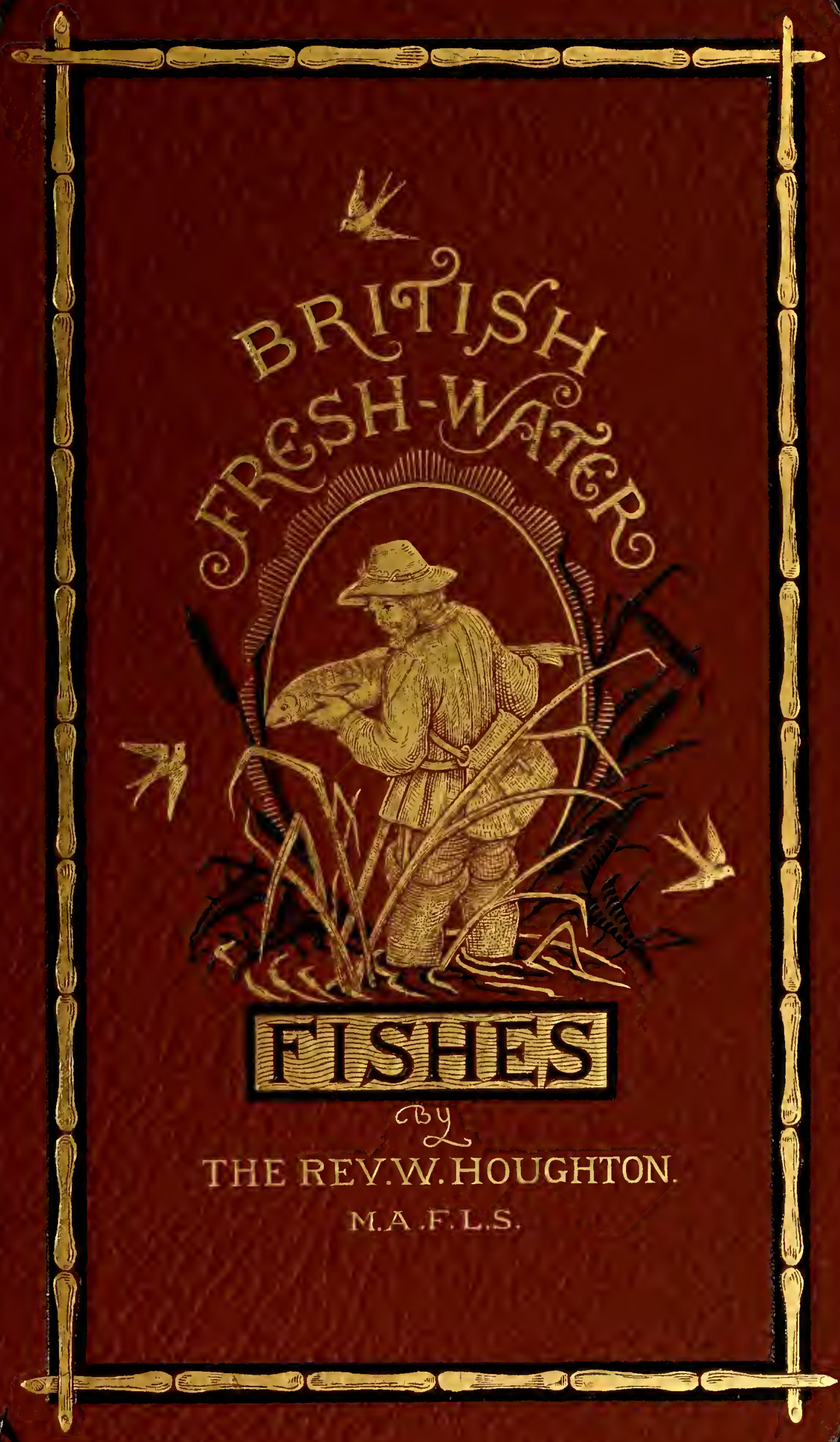




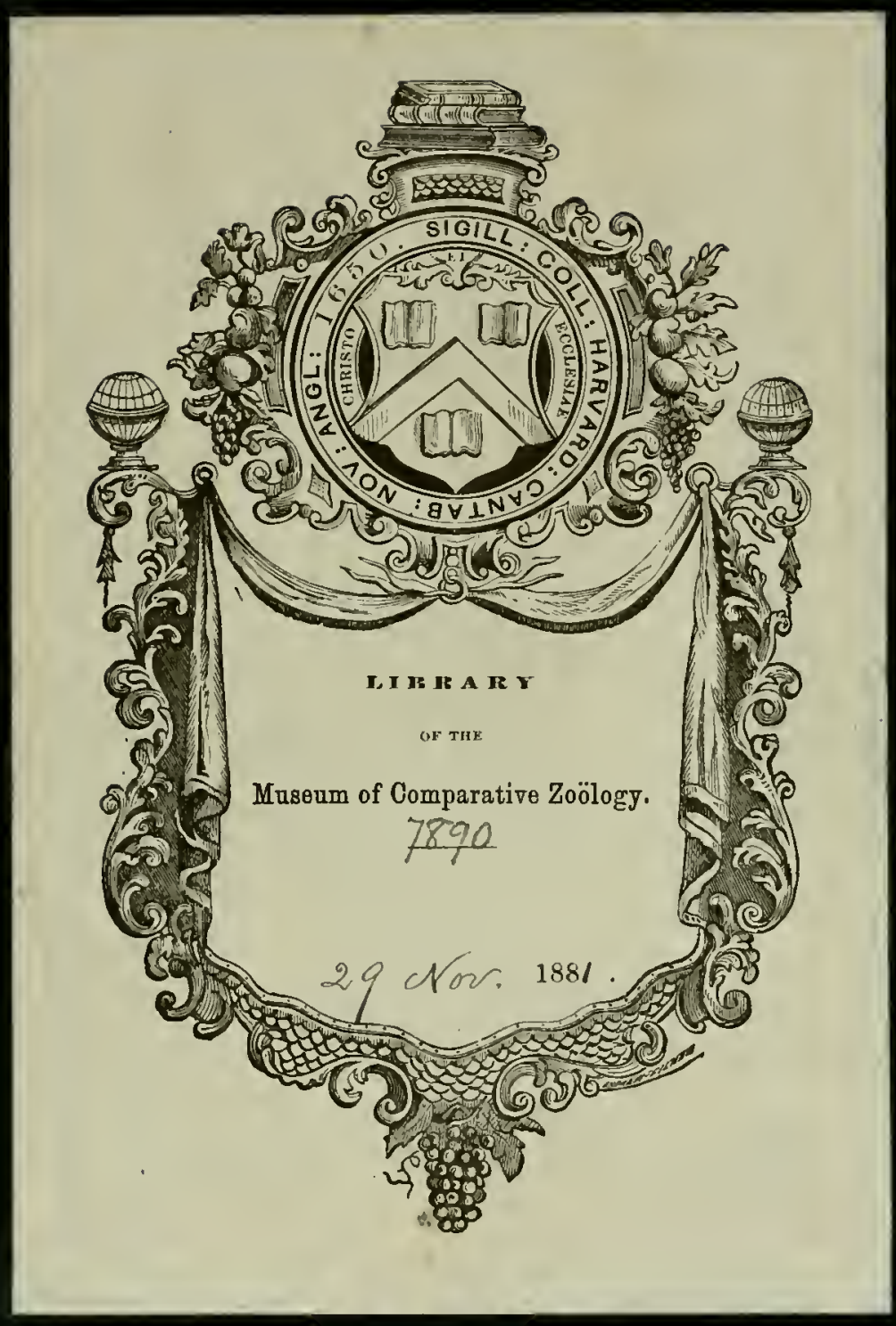






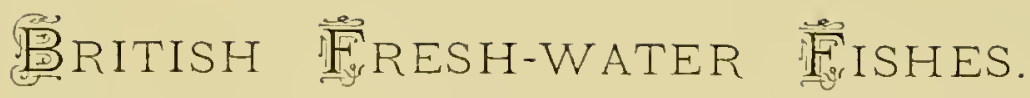






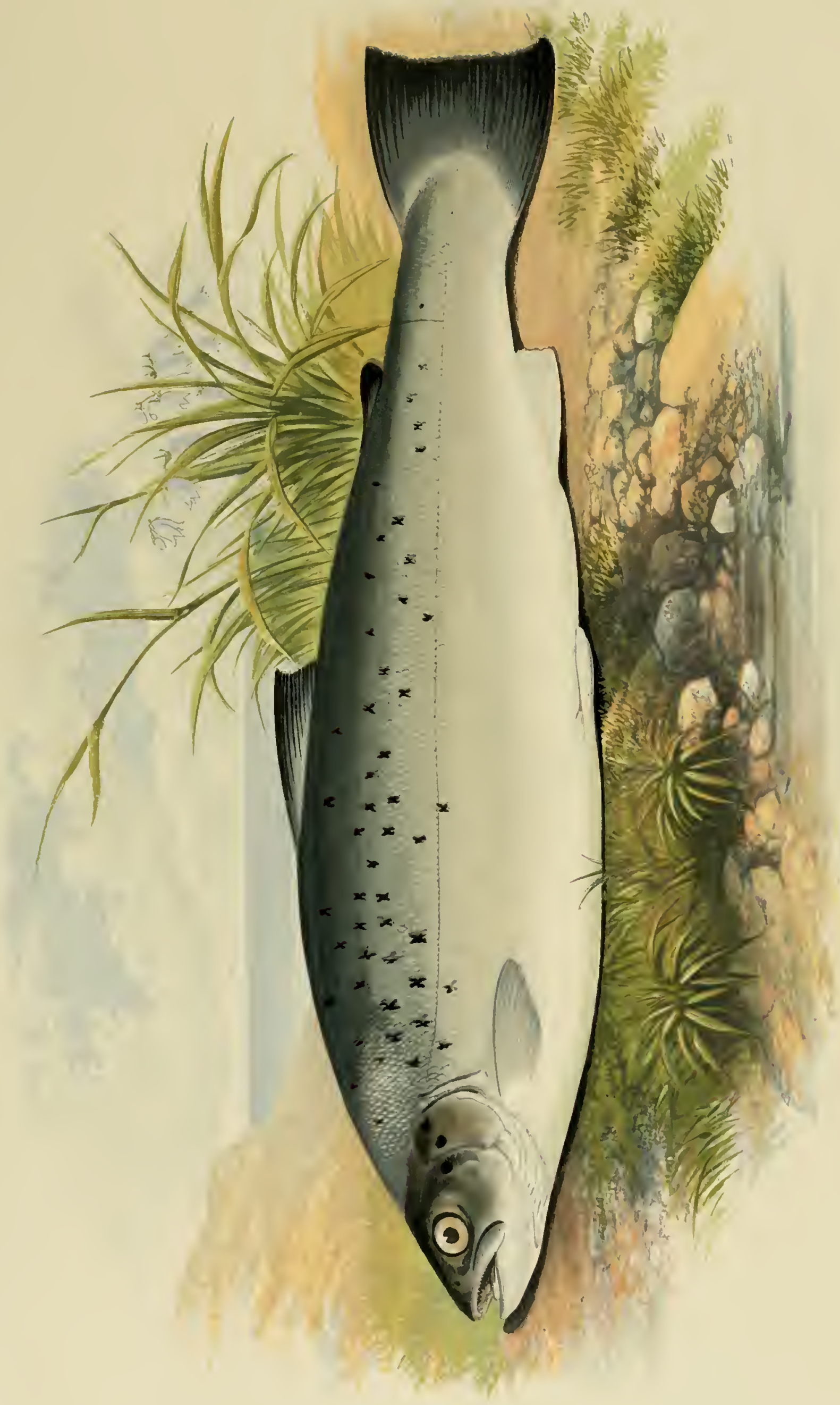




\section{BRITISH}

FRESH-WATER FISHES

H)

THE REV. W. HOUGHTON, M.A.. F.L.S.,

RELTOR OF PREFTOX-ON-THE-WEALD MOORS, SHROPNHIRE.

Author of "Sta-side Walks of a Naturalist," de.

II.I. US TRATED WITH

A COLOUREU FIGURE OF EACH SPECIES DRAWN FROM NATURE BY A. F. LYION, ANI NEMEROES ENGKAVINGS.

U L S S N D ON:

WILIAM MACKENZIE, 69, LUDGATE HILL, E.C EDINBURGH AND DUBLIN 
MCZ LIBRARY

HARVARD UNIVERSITY

CAMBRIDGE. MA USA 


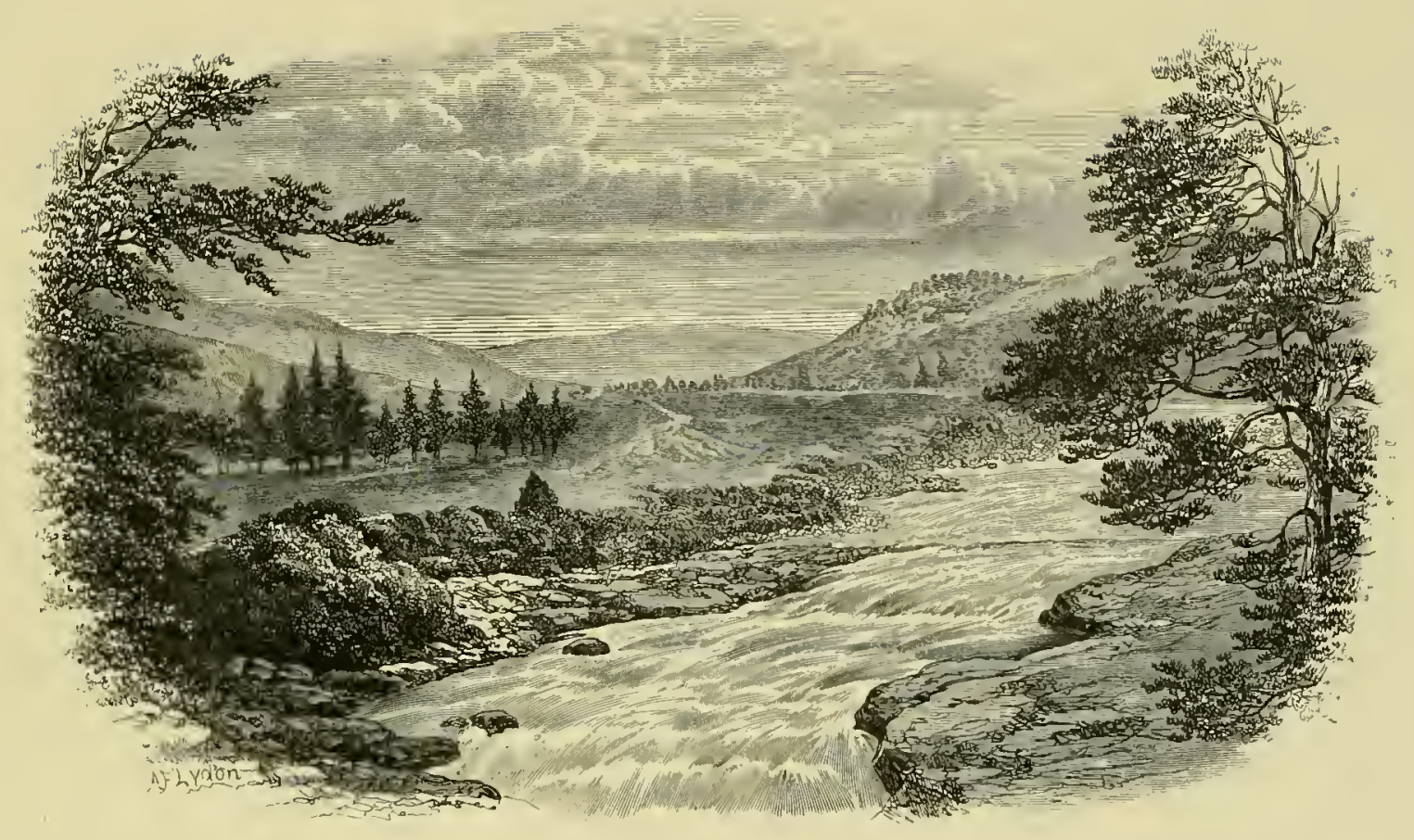

On the pee, Scotland.

Order $I V$.

PHYSOSTOMI.
Family'

SALMONID EE.

Sub-generic Group-SaLmones.

\title{
SALMON 盘ROUT.
}

\author{
(Salmo trutta.)
}

\author{
Trutta salmonata, The Scurf or Bull Trout, \\ White Salmon, \\ Salmo trutta,
}

Trutta trutta,
Willughby, Hist. Pisc. p. 193.

Pennant, Brit. Zool. iii. p. 396 , ed. 1812 .

Fleming, Brit. Anim. p. 180; Jenyns' Man. p. 423;

Yarrell, ii. p. 77; Parnell, Fish. Firth of Forth (Mem.

Wern. Nat. Hist. vii. p. 293); GüNTheR's Cat. vi. p. 22.

SiEbold, Süsserwasserf. p. 314 .

THE Salmon Trout, or, as it is also called, the Sea Trout, is, perhaps, next to the Salmon,

1 the most valuable of all the migratory species. It is most abundant in the rivers of Scotland, but it occurs also in those of Ireland. In England and Wales it would seem that this species is represented by the closely allied, if really distinct species, of the Sewen, or Salmo cambricus. Dr. Günther states that all the British specimens of Salmo trutta which he has examined, with the exception of the Fordwich Trout, were from Scotland, and those obtained from the rivers of Wales and Southern England belonged to Salmo cambricus.

The Fordwich Trout is mentioned by Izaak Walton, who says, "There is also in Kent, 
near to Canterbury, a Trout called there a Fordidge Trout, a Trout that bears the name of the town where it is usually caught, that is accounted the rarest of fish; many of them near the bigness of a Salmon, but known by their different colour; and in their best season they cut very white; and none of these have been known to be caught with an angle, unless it were one that was caught by Sir George Hastings, an excellent angler, and now with GoD; and he hath told me, he thought тHAт Trout bit not for hunger, but wantonness; and it is the rather to be believed, because both he, then, and many others before him, have been curious to search into their bellies, what the food was by which they lived, and have found out nothing by which they might satisfy their curiosity."-(Complete Angler, i. p. 145, ed. Hawkins.) Yarrell says that the ancient right to the fishery at Fordwich was enjoyed jointly by two religious establishments; and that it is now vested in six or seven individuals, who receive a consideration for their several interests. It was formerly the custom to visit the nets at Fordwich every morning to purchase the fish caught during the night. "I have seen," he adds, "specimens of the Salmon Trout from the Sandwich river exposed for sale in the fishmongers' shops at Ramsgate." The specimen in the British Museum from Fordwich is very fine, being a female, nineteen inches long.

There seems to be no doubt that in some localities the term Bull Trout is applied to this species under consideration; Dr. Günther identifies the Salmo eriox of Yarrell and other writers with the Salmon Trout, and thinks that no distinct species is designated by the name of Bull Trout, which is applied to different species at different localities and by different persons. I am inclined to think that the Salmo criox, as described by Yarrell, is a distinct species; it will, however, be considered separately in the course of this work. The White Trout of the angler-the Peal, or Salmon-peal, as it is also called-is the grilse state of this species (S. trutta), as well as that of the Sewen (S. cambricus).

In Scotland the Salmon Trout is equally abundant with the Salmon, and large quantities find their way to the London fish dealers. When I was in Belfast in July, 1878, I saw numbers of these fish in the markets, but it appears to be less widely distributed in Ireland than in Scotland, though said by Thompson to be common round the coast. Sir IVilliam Jardine, in his Illustrations of Salmonida, says that in approaching the entrance of rivers, or in seeking out, as it were, some one they preferred, shoals of this fish may be seen coasting the bays and headlands, leaping and sporting in great numbers, from about one pound to three or four pounds in weight; and in one of the smaller bays the shoal could be traced several times circling it, and apparently feeding. "In these bays," he continues, "they are occasionally taken with a common hang-net, stretched across; and when angled for in the estuaries, with the ordinary flies which are used in the rivers of the south for grilse, rose and took so eagerly that thirty-four were the produce of one rod, engaged for about an hour and a half. They enter every river and rivulet in immense numbers, and when fishing for the Salmon are annoying from their quantity. The food of those taken with the rod in the estuaries appeared very indiscriminate; occasionally the remains of some small fish which were too much digested to be distinguished; sometimes flies, beetles, or other insects, which the wind or tide had carried out; but the most general food seemed to be the Talitrus locusta, ${ }^{*}$ or common sandhopper, with which some of their stomachs were completely crammed. It is scarcely possible to arrive with any certainty at the numbers of this fish. Two hundred are frequently taken at a single draught of the net, and three hundred have occasionally been counted." The rivers most noted for Salmon Trout in Scotland are the Tweed, Spey, Don, and the Tay.

To the fly-fisherman the Salmon Trout affords great sport. Mr. Francis says, "The

* The T. locusta is a terrestrial amphipod, and never roluntarily seeks the water; if this was the species, they must have been carried out by the tide. 


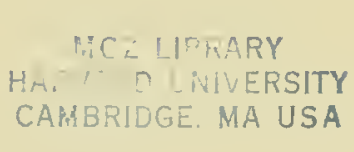




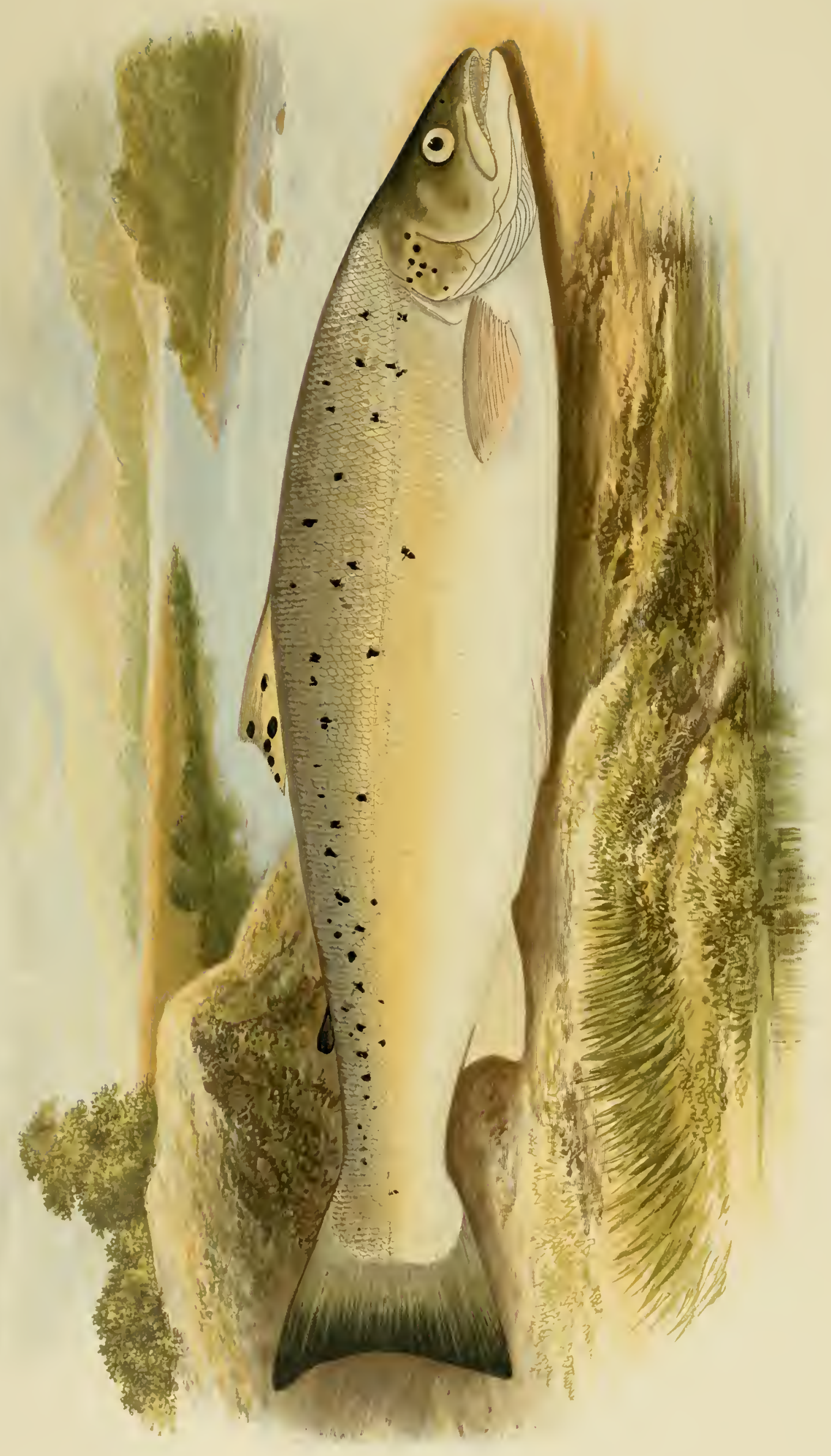


white Trout is one of the gamest fish that swims. Like a champion of the light weights, he is all activity. When hooked, he is here, there, and everywhere, now up, now down, now in the water and now out: indeed an hour or two's White-Trout fishing, when the fish are in the humour, is about as lively and pleasant a sport as the angler can desire; and as Salmon Trout often take the fly well, up to six and seven pounds weight, where they are found of that size, the sport is little inferior to the best grilse fishing. They also take a spinning-bait well while still in salt water, and on the west coast of Scotland it is common to fish for them thus. As to where they are to be sought, that experience alone will determine. They abound in many lakes to profusion, and take nobly in them. I have myself caught a hundredweight of them in a day in a lake in Ireland. They are found in most Salmon rivers, and in smaller streams which are too shallow for Salmon. The smallest mountain beck will often, when in state, give good sport. They also, as I have shown, take in salt water, and are quite as likely to be found in the mouth of the river as they are in the highest pool up amongst the mountains, for they are great and pertinacious travellers. You may catch them in Salmon pools, in dull eddies, and in sharp streams; so I can give no advice which would be of any value on that score. They are at times very false risers, and come very short at the fly when making apparently a capital rise. This is very trying to the temper." Mr. Francis concludes that the White Salmon Trout "is the most sporting and game fish which the angler meets with."-(Book on Angling, p. $331-332$.

As to the colour and quality of the flesh, it is generally of deep pink or red, and of excellent flavour; its price is usually the same as that of a Salmon. The flesh of the Bull Trout of the Coquet is said by some to be invariably very light, with scarcely a tinge of pink about it, and to be inferior in quality. I have, however, been informed by Mr. Christie that sometimes the Salmon Trout of the Beauly is also white, and not very good. According to Günther the Salmo trutta attains to a length of about three feet, and the female is mature when from ten to twelve inches long.

In a specimen I received in May, 1878 , which weighed three pounds and a half, the total length was twenty-one inches, the breadth above the origin of the dorsal fin about five inches; length of head to body as one to four; preoperculum with a distinct lower limb; hind margin of gill-cover obtusely rounded; the suboperculum not projecting or scarcely projecting beyond the end of the operculum. In the Sewen the suboperculum does thus project, but not in all cases; the maxillary is thin and feeble, and extends to below the hind margin of the orbit. In the Sewen the maxillary is strong and solid. Colour of the body above lateral line dark bluish, lighter on the sides; belly silvery white; the black $\mathrm{X}$-shaped spots on this fish are generally very distinct; for the most part they are above the lateral line; but occasionally there are a few below; the gill-cover is usually marked with a few round black spots; adipose fin dark, free from any red tinge; the scales are round and small, and easily detached; tail nearly square.

Sir William Jardine (Illustrations, Ec., pl. x, fig. 2,) has figured a brown or sand-coloured variety of the Salmon Trout, which the fishermen of the Solway call "Sandbacks;" our figure (Salmon Trout var.) was taken from a specimen caught at the mouth of the Tweed: it weighed eight pounds. In a specimen I opened I found no trace of any kind of food; the stomach, pyloric cæca, and intestine were full of tania and some other active entozoon, a species of Ascaris; there was some orange-coloured mucus accompanying these contents.

The fin-ray formula is 
According to Dr. Günther there are fourteen or fifteen scales in a transverse series running from behind the adipose fin obliquely forwards to the lateral line.

The specimen figured is from the Tweed. 



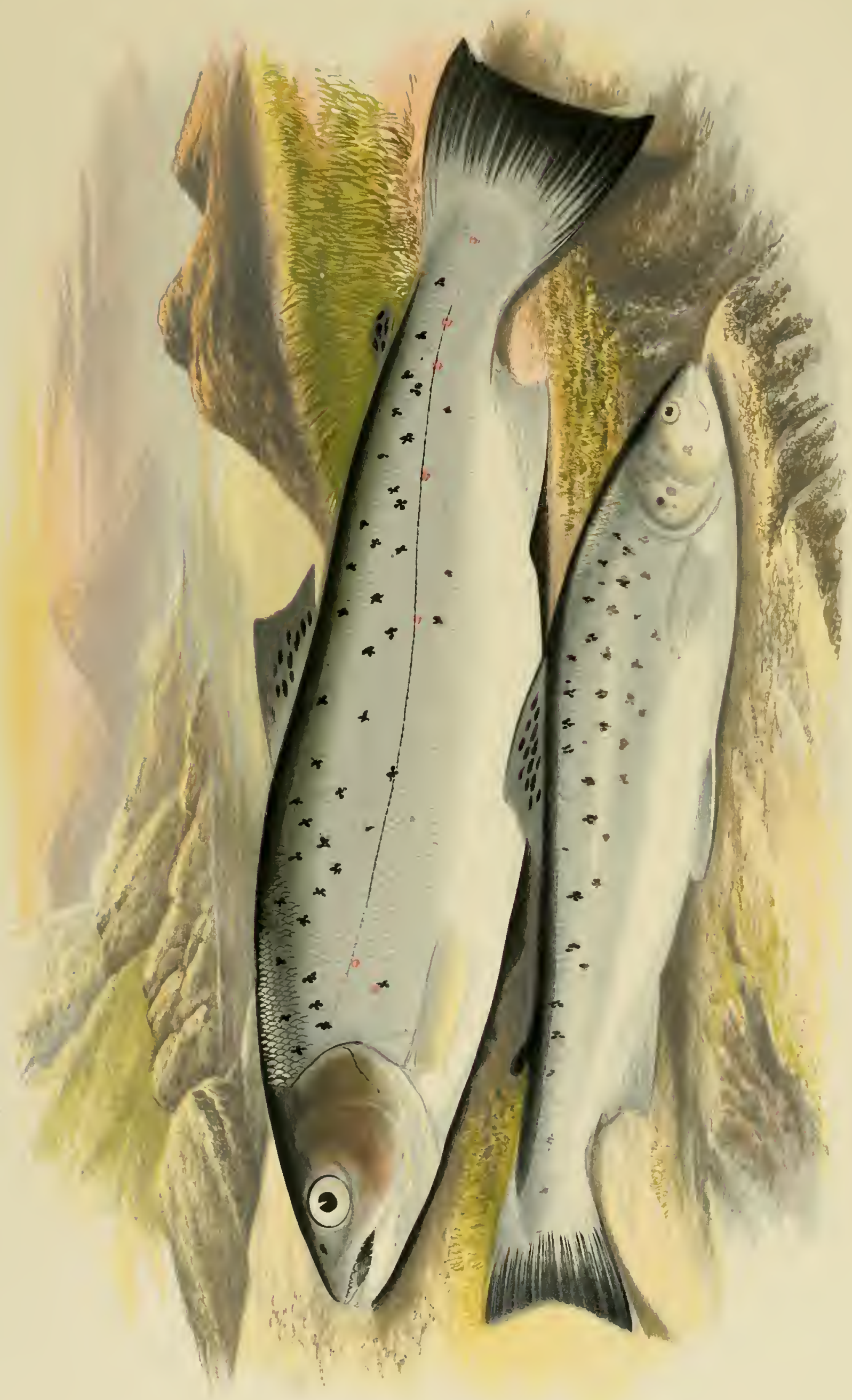

$z$
$z$
3
$z$
0 


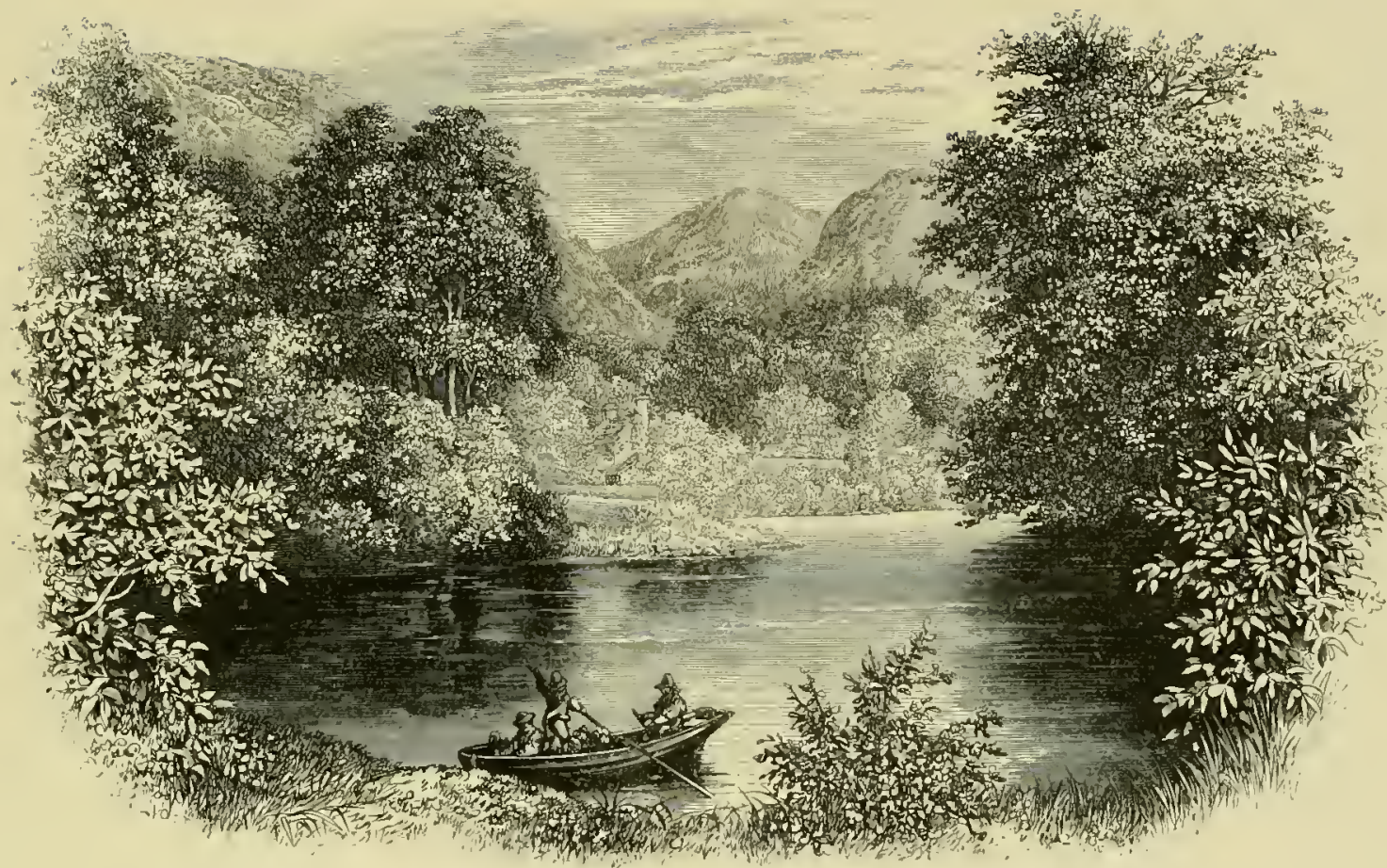

Piver Scene, AbFrglasty

Order $/ I^{r}$

PHISOSTOMI
Family

SALMIONIDAE

Sub-generic Group-SaLmones.

\section{SEWEN}

\section{(Salmo cambricus.)}

Salmo cambricus,

Strein,

Blue Poll (Salmo allus, Flem.).
Donovan's British Fishes, iv. pl. 91; Gínthek's Cat. vi. 1) 3 +. Couch's Fish. Brit. Isl. iv. pl. $213,1 \% 208$ (Grilse state). Couch, iv. p. 2 I 9.

THE Sewen is a species closely allied to the Salmon Trout; it occurs chiefly in WVales, and hence it was named cambricus by Donovan, who has given a tolerable figure of this fish in its grilse state; it is also found in the rivers of the South of England, as in Devonshire and Cornwall, and is said to occur in Ireland. There are continental specimens in the British Museum from Denmark, Norway, and Jutland. In the South of England this fish is known to the angler as the Peal or Salmon-Peal, which terms in Scotland are also applied to the Salmon Trout. Like this last-named species, the Sewen is migratory in its habits, ascending rivers from the sea for the purpose of depositing its spawn. In colouration this fish is subject to considerable variety, more so, I think, than occurs in any other migratory Salmonoid. When taken fresh from the salt water, or from an estuary, or indeed from a river, if it has not long sojourned therein, the colour is a beautiful blue, and greenish on the head 
and shoulders; the X-shaped spots distinct and separate, sometimes occurring only sparingly. After the fish has been some time in the water of a river, the colouration is much more like that of the Common Brown Trout, for which indeed, in this respect, it might be mistaken if hastily examined. Commercially the Sewen is not nearly so important a fish as the Salmon Trout; not, however, because its flesh is a whit inferior in quality, but because it is less abundant than its Scotch relative, and does not find its way much into the markets of our large towns. In South Wales the Sewen is taken by nets in the bays and estuaries early in the year, as in March and April; they are generally from one to four pounds in weight at that time, and are delicious eating. These fish make their way up some of our rivers for a great distance; but, according to some observers, the Sewen is a less muscular fish than the Salmon, and has greater difficulty in ascending the weirs and obstructions. I have seen a large quantity of these fish caught by a net in the Dee, close to the residence of my friend Mr. Bigge, at Min-yr-Afon, near Ruabon, and have had an opportunity of noticing the difference in colour to which I have already alluded.

As a sporting fish the Sewen competes with the Salmon Trout. I am told by the Hon. Henry Butler, an excellent angler, that the best time to fish for Sewen is quite late in the evening, when it is dusk: a small fly and fine gut he recommends as the most successful apparatus. Dr. Günther says that the Salmo cambricus attains to a length of about three feet, and that the female is mature at a length of from twelve to thirteen inches, weighing occasionally as much as sixteen pounds; but such a size and weight is, I suspect, unusual. It seems that the term "Bull Trout" is sometimes applied to specimens of this fish, as it is to the Salmon Trout and perhaps to other species of Salmonide. This will be considered when I come to speak of the Bull Trout of the Coquet.

The following is a description of a specimen of Sewen I procured at Machynlleth in June, I 878:- Total length was sixteen inches and a half; its weight was two pounds; the greatest depth was four inches and a quarter; length of head three inches and a quarter; the maxillary strong, longer than snout, and reaching beyond the posterior orbit of the eye; mandible strong and broad; præoperculum with distinct lower limb, its posterior margin waved; gill-cover with a few round dark spots, sometimes iridescent with pink; suboperculum generally projecting beyond the operculum; dorsal fin smoky, with a few darker spots; adipose fin thick and fleshy, with two or three black spots; pectoral fin white, with dark narrow longitudinal lines; ventral white and immaculate; anal ditto; tail slightly emarginate, light smoke-colour, and dark at extremity; the head and upper parts of the back tinted with olive green; general colour of the body above lateral line bluish, with lighter shades of blue on the sides, spotted with numerous dark X-marks more or less distinct, the spots sometimes confluent; below lateral line there were a ferv indistinct spots; belly silvery white; scales small and rounded.

The number of rays in the fins is

Dorsal 14.

Pectoral 16

Ventral 9 .

Anal II -12 .

The specimen figured was caught in the Dovey near Machynlleth. 



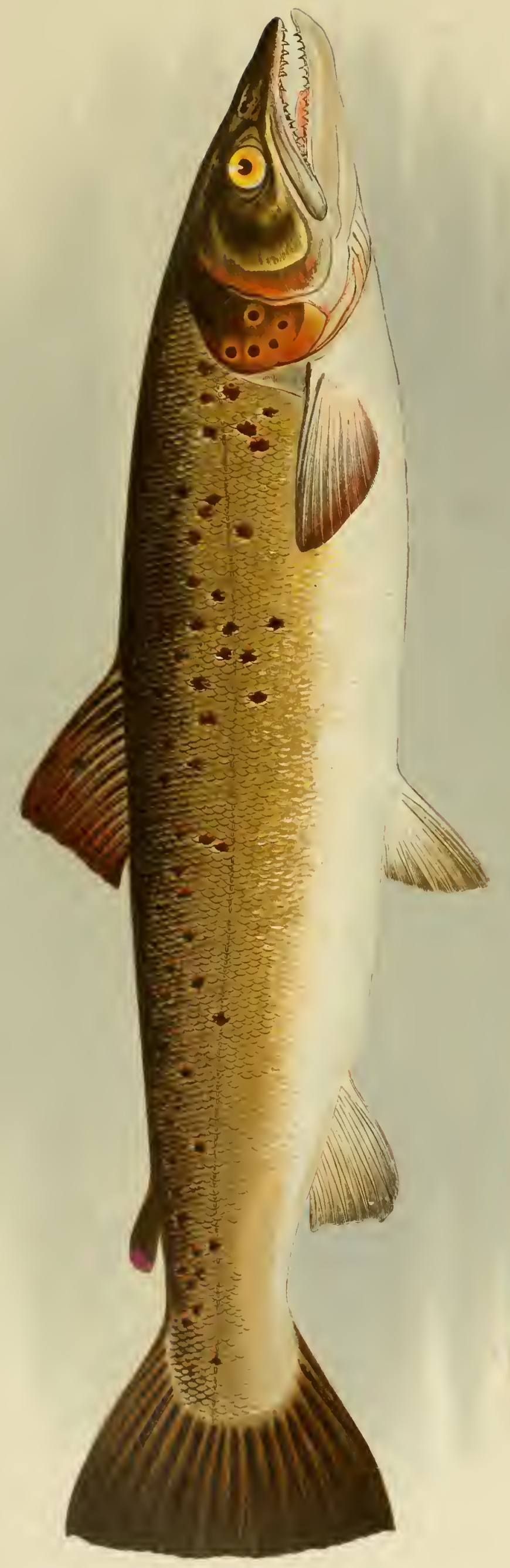




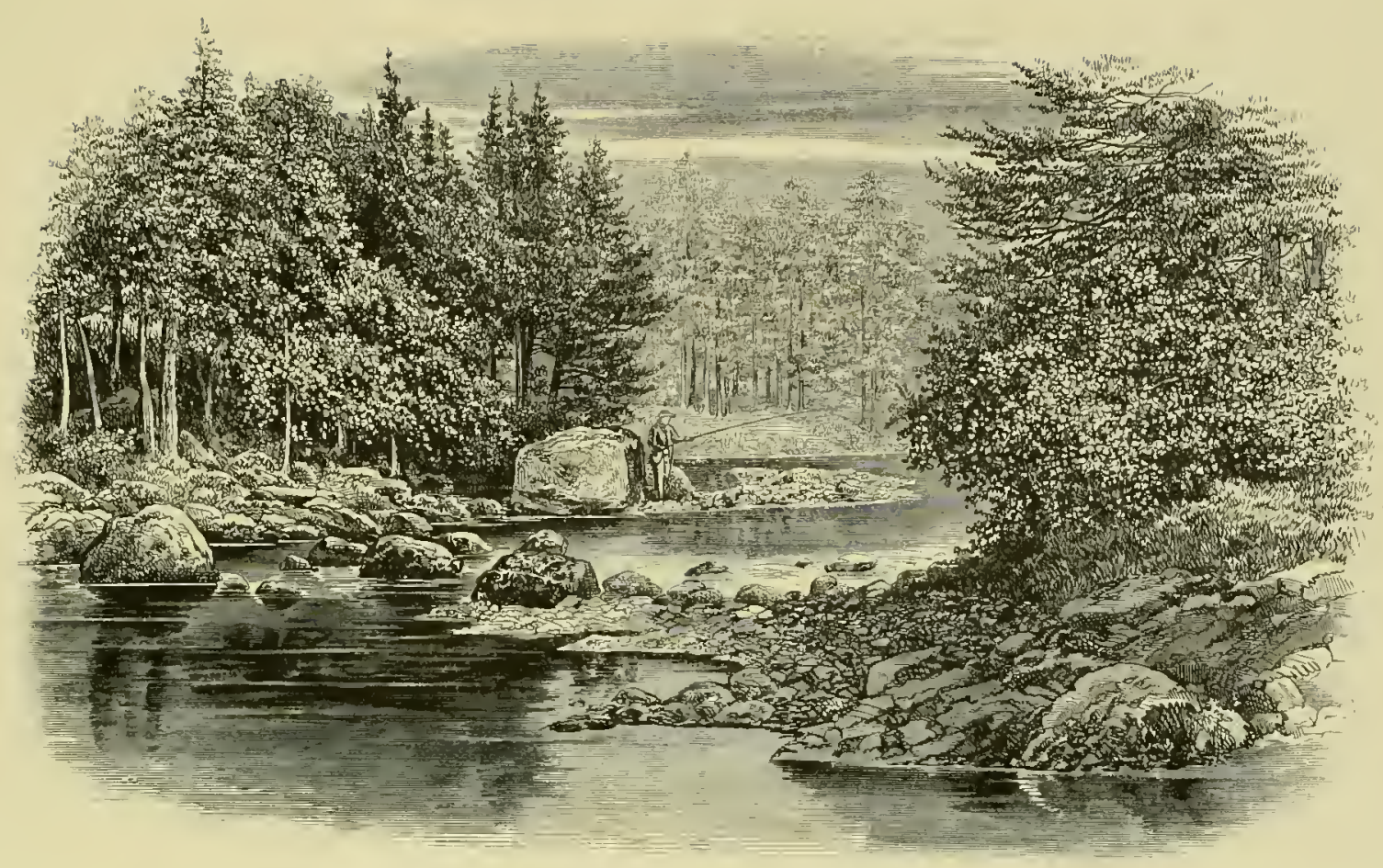

River SCEne, Langdale.

Order 11 .

PHTSOSTOMI.
Family,

SALMONIDE.

Sub-generic Group--SaLmones.

\title{
蛋Ull Trout.
}

\author{
(Salmo eviou.)
}

The Scurf, Trutta salmonata, and Bull Trout, etiam dicta, Salmo eriox, Grey Trout, Roundtail,
IVIllughiy, Hist. Pisc, p. 193.

YARRELL, Brit. Fish. ii. p. 71 .

" NO distinct species," says Dr. Günther, "is designated by this name (Bull Trout); at all events the name is applied to different species at different localities, and by different persons. We have received numerous examples of $S$. trutta under this denomination; I have also seen stuffed examples of 'Bull Trout,' each of them of a peculiar aspect, but without any characters by which the species could be determined. It would appear that many examples somewhat differing in general aspect from S. trutta are named Bull Trout." (Cataloguc, vi. p. 23, note.) In his Addenda (p. 356) the same learned ichthyologist thus writes of a fine male sterile specimen of Salmo salar three feet long, caught in the Beauly at the beginning of April, and presented by Lord Lovat as "Bull Trout:"—“"Whilst this sheet was passing through the press, Lord Lovat's kindness afforded me an opportunity of seeing other specimens of 'Bull Trout,' at the moment when taken out of the water. It is his opinion that at least some of the fish are hybrids between the Salmon and Sea Trout ( $S$. 
trutta), an opinion confirmed by external appearance, and by the varying number of pyloric appendages, which in one specimen was found to be as low as fifty-four; yet the relative size of the scales on the tail is in all these Bull Trout the same as in the Salmon. Captain H. Fraser believes that other specimens of Bull Trout are true Salmon, which, having gone down to the sea as kelts, return to fresh water before having attained to the condition of well mended fish. Thus, as regards the river Beauly at least, fishes named 'Bull Trout' do not constitute a distinct species, but this name would appear to comprise-

1. Hybrids between Salmon and Sea Trout.

2. Specimens of Salmon returning from the sea before being well mended.

3. Sterile specimens-as, for instance, the specimen mentioned above.

The differences between 'Bull Trout' and Salmon are sometimes so slight as to be scarcely perceptible by an inexperienced eye. From what I have seen on the Beauly in the month of August, I should say that the numbers of Salmon, Bull Trout, and Sea Trout are as $30: 3: \mathrm{I}$.

I may also add here that I have seen specimens of Salmo brachypoma in the same river, and that they are named there 'Phinok,' a name used for the grilse state of S. trutta on other rivers."

A gentleman, Mr. R. S. Congreve,-writing from Balmaghie, Castle Douglas, N.B.,-who has considerable experience as a Salmon-fisher, believes the Bull Trout of Scotland to be the Common IVhite Trout (Salmo trutta). He thinks "that at a certain unknown age they cease from breeding, and also that they cease from going down to the sea in the spring, and from coming up into the rivers in the autumn; that they then grow to a large size; in Loch Awe they are frequently caught of a great size, but never are of the silvery white colour characteristic of the Sea or Salmon Trout that ascend and descend the rivers annually; the scales are imbedded in the skin." He adds, "I myself have caught one of sixteen pounds weight, and have known them caught over twenty pounds."

Mr. Gillone, of Tongueland, Kirkcudbrightshire, considers the Bull Trout of the Dee to be simply a diseased Salmon. He says as a rule the flesh is not quite so good for eating as the Salmon; that in seven cases out of ten it will cut white and eat dry; but that exceptional cases occur in which the flesh cuts as red as that of a Salmon.

Thus it is certain that various species of Salmonide are sometimes designated as Bull Trout. Is there, however, no distinct species to which the name should be applied? There is one river in the north of England, the Coquet, where these so-called Bull Trout abound, to the exclusion of other migratory Salmonida. Through the kindness of Sir Walter Riddell, Bart., I have been fortunate enough to procure from Mr. Jacob Douglas, the keeper at Hepple, Rothbury, four fine specimens of these Bull Trout-three males and a spent female. (Nov. I 8-29, 1878.) I have also a few young specimens in their parr state, obligingly given me by Mr. Frank Buckland.

Whether this Coquet fish is really a distinct species I will not take upon myself to determine, but it most decidedly deserves a separate plate and description. Certainly it does fairly well answer to Dr. Günther's description of Salmo trutta; but it is said that there is this remarkable peculiarity about the Coquet Bull Trout-it is almost white in the colour of its flesh, and very inferior as an article of diet. Mr. Dunbar, in a letter he has been good enough to write to me, says that the flesh is "very poor in flavour, and cuts nearly as white as a Cod; in fact they are not half so good as Cod." He adds that there are very few rivers in Scotland where there are not some of these Bull Trout; but of all the other rivers in the kingdom the Coquet may be said to be a pure Bull Trout river, for there are at least one hundred of these fish to every Salmon, and they run up to twenty-five pounds in weight. "I have taken," he say's, "over a ton weight in a morning, and not one Salmon in the lot." Of 
course this question is of great importance, for in the Coquet this inferior Salmonoid has nearly exterminated the Salmon. These fish are stronger than the Salmon, and, as Mr. Buckland says, "arising simultaneously with the Salmon at a weir, both species endeavour to ascend, and if there was no weir, both would equally ascend. The Bull Trout is the stronger animal of the two, and as there happens to be a weir, the chances are in favour of the Bull Trout as against the Salmon. A pair of Salmon and a pair of Bull Trout arrive at a weir at the same time; the Bull Trout by their superior strength get over the weir; the Salmon remain behind. If this operation be repeated time after time, the consequence will be that the Bull Trout arrive first at the best spawning places and deposit their ova, while the Salmon remain miles away down the river, and possibly do not get over the weir at all."-(P. 3Ir.) Mr. Buckland's testimony as to the flesh of this fish coincides with that of Mr. Dunbar,- "the flesh is white and without the pure Salmon flavour, to which it is far inferior."

This fish is more frequently found upon the east coast of England than upon the west. "There are Bull Trout in the Tweed," writes Buckland in 1873 , "the Coquet swarms with them, and the Tyne reports an increase." In order to restore the Salmon, the Home Secretary has given the Duke of Northumberland and the Board of Conservators permission to destroy the Bull Trout when they are running up the river in September, October, November, and December. The Bull Trout thus possesses the very unenviable distinction of being the only Salmonoid which is of inferior quality as food; as to its value as sport opinions differ. Some of the proprietors on the sides of the Coquet, I learn from Mr. Dunbar, of Brawl Castle, Halkirk, consider that the Bull Trout is a good sporting fish, and on this account they wish it to be protected by law. Lord Home, in a communication made to Mr. Yarrell (vol. ii. p. 73) some years ago, writes of this fish as follows:-_"The Bull Trout has increased in numbers prodigiously within these last forty years, and to that increase I attribute, in a great measure, the decrease of Salmon Trout, which formerly abounded when I was a boy.* It is now a rare thing to see a Salmon Trout or Whitling, -for the Whitling in the Tweed is the Salmon Trout, not the young Bull Trout, which now go by the name of Trouts simply. The Bull Trout take the river at two seasons. The first shoal come up about the end of April and May. They are then small, weighing from two to four or five pounds. The second, and by far the more numerous shoal, come late in November. They then come up in thousands, and are not only in fine condition, but of much larger size, weighing from six to twenty pounds. The Bull Trout is an inferior fish, and is exactly what is called at Dalkeith and Edinburgh, Musselburgh Trout. Mr. Yarrell is mistaken when he says that these fish afford good sport to anglers; quite the contrary: a clean Bull Trout in good condition is scarcely ever known to take fly or bait of any description. It is the same in the Esk at Dalkeith. I believe $I$ have killed as many, indeed I may venture to say I have killed more Salmon with the rod than any one man ever did, and yet put them all together I am sure I have not killed twenty clean Bull Trout. Of Bull Trout kelts thousands may be killed. The great shoal of these Bull Trout, not taking the river till after the commencement of close time, are in a great measure lost both to the proprietor and the public." Mr. F. Buckland was informed by Mr. Dunbar that the weight of Bull Trout caught between February and August, I871, was seventeen thousand seven hundred and thirty-seven pounds, and only two Salmon were taken; from the ist. of September to December, 1871, the weight of Bull Trout destroyed was forty-five thousand nine hundred and forty-two pounds, but only thirteen Salmon, and the same number of Salmon grilse.

Bull Trout are, in their grilse state, very destructive of Salmon eggs; but, doubtless, this is more or less true of the Salmonida generally, which are always ready to take ova with

* It appears from this statement that Lord Home regarded the Bull Trout as a distinct species from the Salmon Tront. 
avidity. Sergeant Harbottle, officer of the Tyne Salmon Fishery, Tynemouth, states that as he was taking Salmon for the sake of procuring ova in December, I87I, he caught two Bull Trout, which disgorged Salmon eggs. "By a slight pressure of the hand," he adds, "I squeezed out of their stomachs nearly three wine-glassfulls of Salmon eggs, which would be about two or three thousand in number. These specimens weighed about one pound and a half apiece. It thus becomes a very important question practically to determine in what way the Salmon laws, with regard to this fish, may be altered; because what has happened in the Coquet, where Salmon have been nearly exterminated, and the Bull Trout have increased, may happen in other rivers, and thus a valuable source of food be diminished. It is also important to determine to what species this Bull Trout belongs. If, as Dr. Günther thinks, the Tweed Bull Trout, which I suppose is identical with the Coquet fish, is only the Salmon Trout, or Salmo trutta; then we have this rather curious anomaly, that the same species is both commercially of great value, and at the same time comparatively worthless. No doubt the quality of the flesh of some of the Salmonida varies considerably, even in specimens taken out of the same water; but there is a much greater difference when the fish inhabit different waters. Let us take the Trout, for instance; often in the same river one fish may be white in colour, and inferior in quality; another may be pink and well-flavoured. There is not a finer fish perhaps in the whole world than a good-sized Trout from Lough Neagh, with its red flesh and layers of white curd abundant; but a Trout from another water, where food is scant, is a very poor thing, and its flesh pale and insipid. But what causes should combine to render the Coquet and Tweed fish so very inferior in the quality of, and so different in the colour of its flesh from the ordinary Salmo trutta, it would indeed be difficult to say.

Mr. Buckland says, "It has been supposed by some that the Sea Trout and Bull Trout are identical. I know the Bull Trout very well indeed, and could pick him out among a thousand other kinds of Salmonida. I am certain, therefore, that there is a difference between the ordinary Sea Trout and the Bull Trout."

Mr. Dunbar, in a letter to me, says, "they are certainly a distinct species; they go by themselves, and breed by themselves." Dr. Günther writes, "Yarrell's collection of these fishes was chiefly composed of English and Welsh specimens, and he promiscuously named a part S. truttu, and another S. criox, generally applying the former name to females (with a shorter head), and the latter to males (which have the head more elongate). However he was perfectly right in directing attention to the shape of the gill-cover, which is very characteristic for the two species, at least in most of the individuals. But he was not aware that numerous variations occur, and that there are specimens of S. trutta and S. criox (cambricus) which have the gill-covers of precisely the same shape."-(P. 28.) Dr. Günther, therefore, is of opinion that the S. criox, or Bull Trout of Yarrell, may be either the Salmo trutta or the $S$. cambricus.

I may mention, with regard to the gill-cover, that Yarrell is certainly in error as to its shape in this fish. In all the four specimens before me the line of junction of the operculum and suboperculum is not "nearly parallel with the axis of the body of the fish," as represented in the vignette at page 5, central figure, but oblique; I can see no difference between the gill-cover of the Bull Trout and that of the Salmon Trout, excepting that perhaps the posterior or vertical margin of the præoperculum is more distinctly waved. I think also that the maxillary, which reaches far beyond the posterior orbit of the eye, is longer than in the Salmon Trout. However, leaving the matter as to species, scientifically considered, undecided, I have thought it right to give a prominent place to this fish; for whether it be S. trutta, or, as I was at first inclined to think, a distinct species, the S. criox of Yarrell, for all practical purposes it must be regarded, especially in the quality of its flesh, as different from any other of the Salmonide.**

* This was written before I had received Mr. W. R. Pape's letter, which will be found further on. 
The following is a description of a male Bull Trout received on the 18 th. of November, 1878. For distinction's sake I shall call this fish "The Bull Trout or Pale-fleshed Salmon Trout of the Coquet."

Total length from snout to the end of the tail twenty-eight inches and a half; girth of body twelve inches and a half; length of head seven inches; præoperculum with distinct lower limb; vertical margin sinuous; posterior margin of operculum rounded; sub-operculum not extending beyond operculum; line of union between operculum and sub-operculum oblique; length of maxillary two inches and a half, greatest breadth half an inch; teeth on the maxillaries and mandibles strong; a few only, two or three, on the head of the vomer; body of vomer destitute of teeth; mandible hooked, fitting in a recess in the upper jaw; lateral line distinct, and for nearly all its length straight; dorsal fin greyish pink, with several round black spots; pectoral reddish brown, short, and very broad, margin dark; ventral short and broad; anal purplish grey; tail broad, margin somewhat rounded; adipose fin large and very fleshy, brownish pink with darker spots; the tip of the margin pink; head brownish pink; gill-cover with ten or eleven dark spots; whole colour of the body brownish pink, with a great number of round or obscurely shaped X marks. The whole appearance of this fish is that of a large Trout, being utterly clestitute of the silvery colour of Salmon. This specimen had not parted with all its milt.

Description of a spent female from the Coquet, received November 29th., 1878:-Total length twenty-six inches and a half; girth eleven inches and three quarters; length of head five inches and three fourths; length of maxillary two inches and a quarter; breadth half an inch, reaching beyond orbit of the eye; snout rounded; distance between the end of snout and posterior orbit two inches and five eighths; sub-operculum rounded, and extending beyond the margin of the operculum; tail square; colour of the top of the head olive brown; gillcover lighter; back dark, with bluish tinge and numerous dark spots, not very distinctly $\mathrm{X}$-shaped; fins broad and short; colour below the lateral line silvery grey. The whole appearance of this female fish is more that of a Salmon than a Trout; there is great difference in colour between the male and the female; the head of the female, moreover, is less elongate than that of the male.

In a head of a male fish which measures thirty-two inches, just the size of that described by Yarrell-whose description, with the exception of the form of the gill-cover, already alluded to, is very accurate-the maxillary is narrow but of great length, extending considerably beyond the orbit of the eye; its length is two inches and four fifths; greatest breadth two fifths of an inch; the maxillary of the female is shorter and broader; the operculum and the maxillary in the male resemble those of the Salmo trutta; the same parts in the female are more like those of the Sewen, or Salmo crmbricus.**

Young specimens, obligingly sent to me by Mr. F. Buckland, which were hatched in February, 1878 , attained the length of about three inches in November; but there is difference in this respect, some being less, others more than three inches; the parr marks number about eleven. These little fish are much spotted with brown, and are destitute of any red marks; the dorsal fin is strongly marked with dark brown oblong spots; the other fins are colourless, except the adipose, which is tinged with red.

The evidence with regard to this fish is in some respects most conflicting. Since the above has been in type I have received two more letters, one from Mr. W. R. Pape, of Newcastle, and the other from Mr. Dunbar. Both these gentlemen have had great opportunities of observing the Bull Trout. The former says, "The Coquet Salmon Trout is, I think, identical with all the Scotch Salmon Trout which I have seen. No fish varies so much in colour according to the sea weed and shades of the rocks where they feed; this is easily seen in

* There is difference in the comparative length and breadth of the maxillary; one male in my possession has this organ strong and broad, as in $S$. cambricus. 
varieties the fishermen get from various parts of our coast. The Duke of Northumberland tried to kill out the Trout in the river, from the year 1868 to 1871 , but the attempt gave general dissatisfaction to all classes, and destroyed the fishing on the sea coast so much, that the fishermen had almost to give up the Trout fishing; about seven or eight licences only were taken out; now, I think, there are thirty-five, since the preservation of the Salmon Trout during the last six years. The Duke of Northumberland, for that reason, is now of the general opinion, that we can get no better fish into the river, and that we must increase and preserve the Salmon Trout, and make the best of them as a food supply. The fishermen now kill twenty times the quantity they could a few years ago. When in season, the flesh of this Trout is pink; in June, July, and August, they get a very high deep pink."

Mr. Dunbar on the other hand writes, "The Coquet grilse of the Bull Trout is far from being anything like so good as the grilse, or, as it is called in the north, the finnock of the Sea Trout; the Bull Trout grilse is of a very pale pink, and very dry, with little or no flavour, while the grilse of the pure Sea Trout, Salmo trutta, is of a rich pink red and of excellent flavour, equal to, if not better, than the grilse of Salmo salar. The Bull Trout is decidedly the Salmo eriox, and is distinct from the S. trutta. I know several rivers in Norway, where they are plentiful; they seldom take a fly, though they will take the spinning bait well. It is the same in the Coquet, they seldom take a fly, excepting when they are returning to the sea as kelts."

The opinion of various observers with respect to this Bull Trout is now before the reader. The testimony as to the quality of its flesh, its character as a sporting fish, and its claim to be considered a distinct species, is conflicting. Structurally it is not easy to find any important difference between this fish and the Salmo trutta; and so high an authority as Dr. Günther would lead one to accept his verdict.

The fin-ray formula is

$$
\begin{aligned}
& \text { Dorsal iz. } \\
& \text { Pectoral it. } \\
& \text { Ventral } 9 . \\
& \text { Anal } \mathbf{~} 1 \text {. }
\end{aligned}
$$

The specimen figured was caught in the Coquet near Rothbury, Northumberland. 



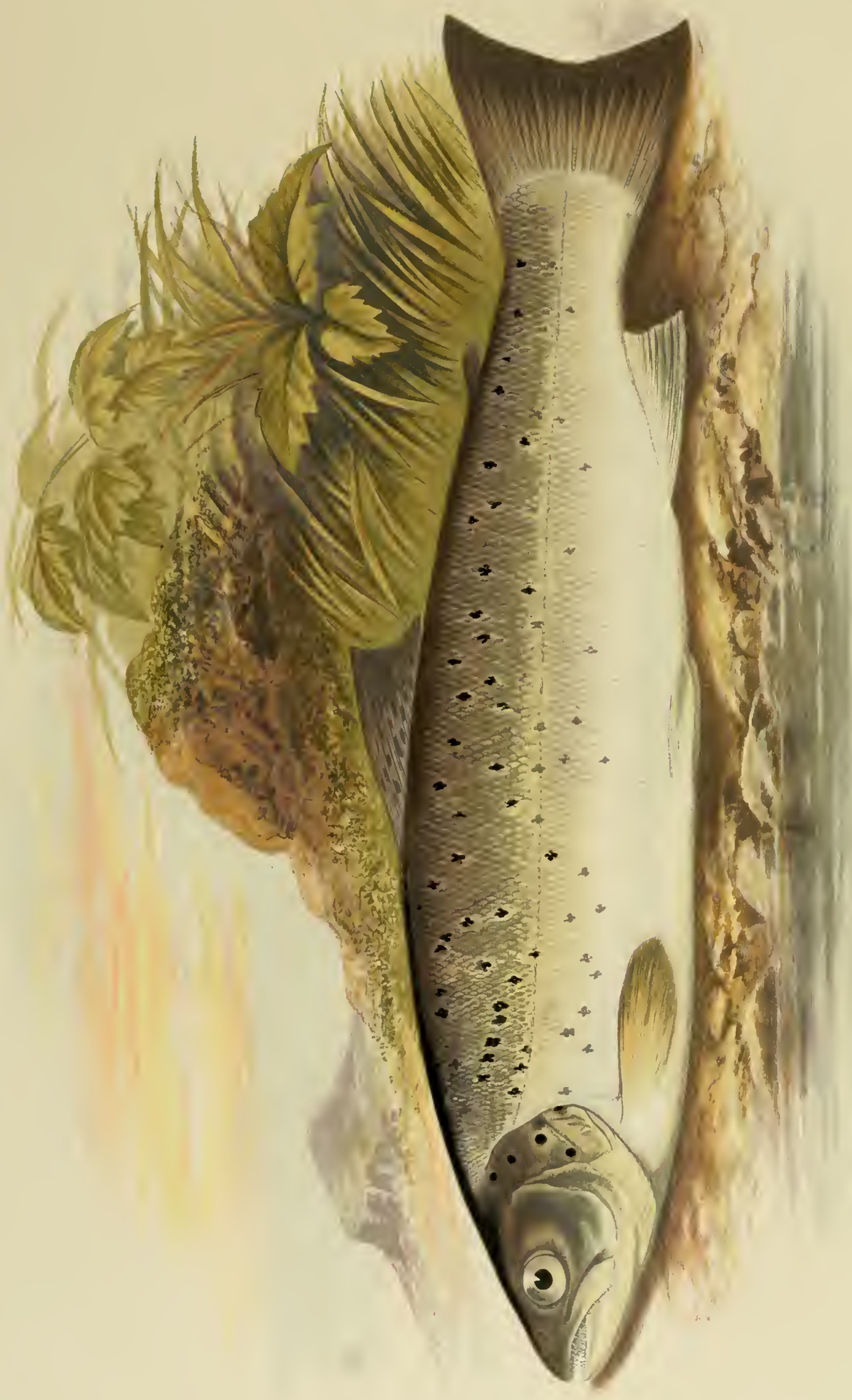




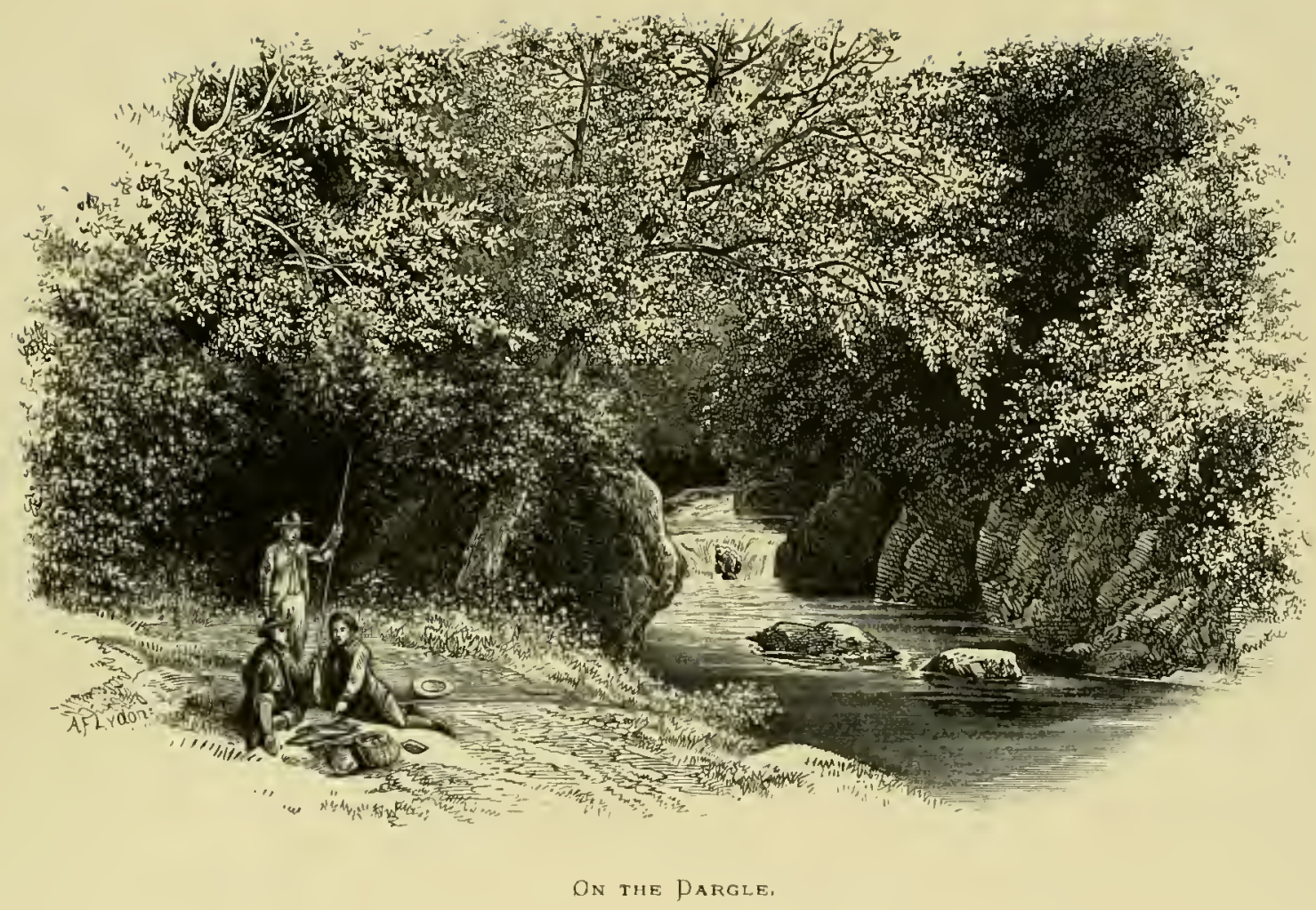

Order II

PHISOSTOMI.

Fimily'

SALITONID.E.

Sub-generic Grouf-SALMONES.

\section{GALWAY SEA TROUT.}

$$
\text { (Sa'mo galliz'cnsis.) }
$$

I AM indebted to Mr. William Haynes, of Patrick Street, Cork, for some specimens of this interesting species of Salmon Trout from Galway. For the knowledge of this species zoological science is indebted to Dr. Günther, who first pointed out its characters. This fish grows to the length of cighteen inches or more; but the specimens so obligingly sent me by Mr. Haynes are about cleven inches in length; others are smolts or parrs with about nine or ten transverse dark markings. As an article of diet it is as good as the ordinary Salmon Trout, from which, indeed, it would not be distinguished by ordinary observers.

The most characteristic peculiarity of this Salmonoid is the small size of the pyloric appendages; in a specimen before me, eleven inches long, these stomachal creca in their greatest length are not much more than half an inch, and about the diameter of a line; as Günther says, "not thicker than the quill of a pigeon." The largest specimen before me 
measures eleven inches and a half; the greatest breadth is not quite three inches; the head is small, more pointed than in S. trutta; the maxillary is feeble, extending slightly beyond the posterior orbit of the eye: in the smolt or parr stage this organ does not extend beyond a line level with the centre of the eye; the preoperculum has a distinct lower limb; the teeth are feeble; the pectorals are long, generally pointed, and streaked with black; the dorsal is spotted; tail more or less forked: in young parrs and smolts this organ is deeply incised; the scales are small and round, those near the tail are very perceptibly larger than the front body scales; general colour above lateral line dark blue with purplish tinge, thickly marked with many $\mathrm{X}$ or $\mathrm{XX}$ dark spots, and silvery below the lateral line; gill-covers with several round black spots.

The fin-ray formula is

$$
\begin{aligned}
& \text { Dorsal I3. } \\
& \text { Pectoral } \mathrm{I} \\
& \text { Ventral } 9 . \\
& \text { Anal } 1 \text { I- } 2 .
\end{aligned}
$$

The specimen figured was procured for me by Mr. William Haynes, as already stated. 



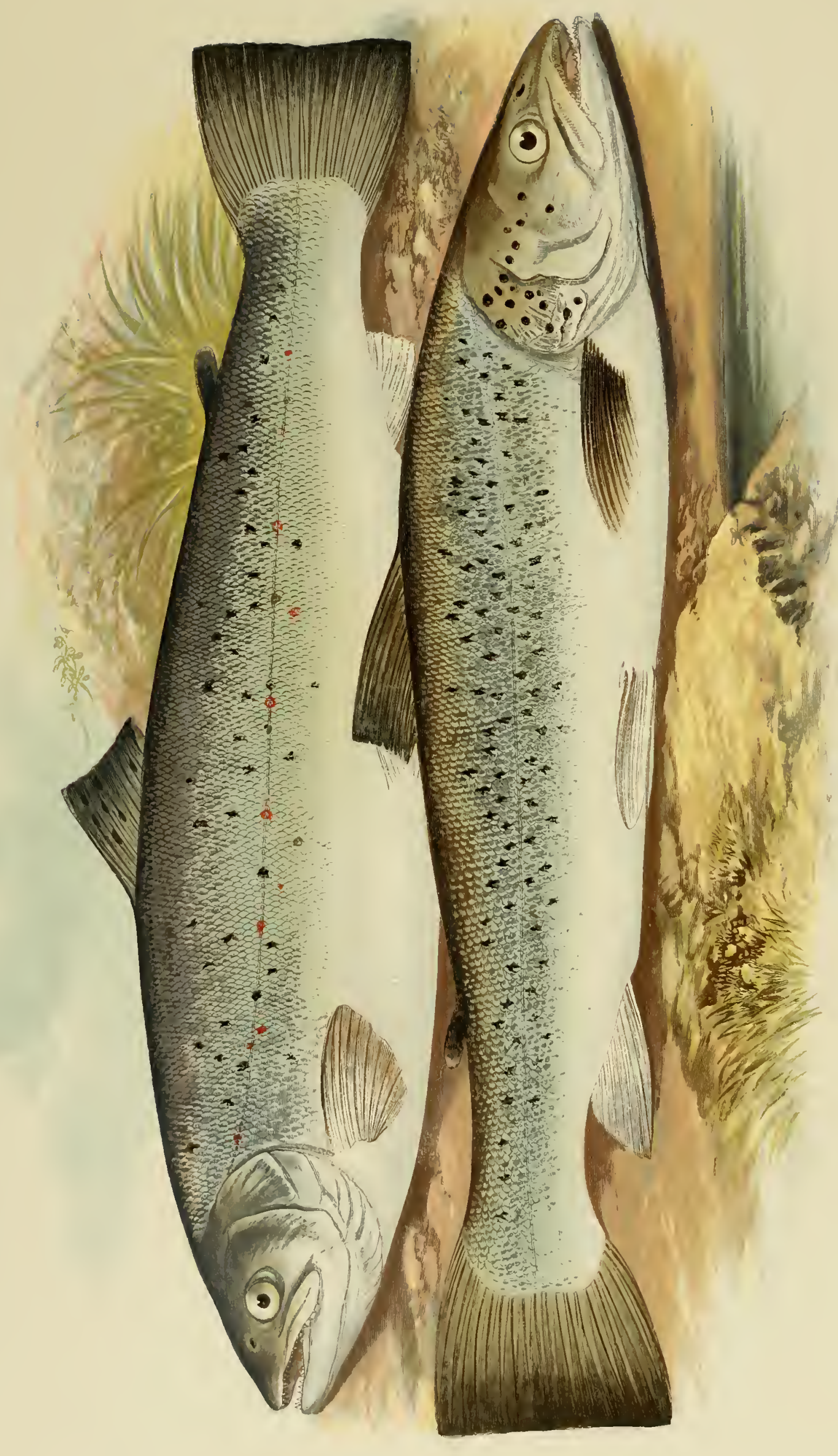

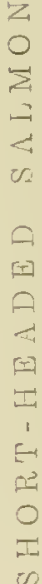




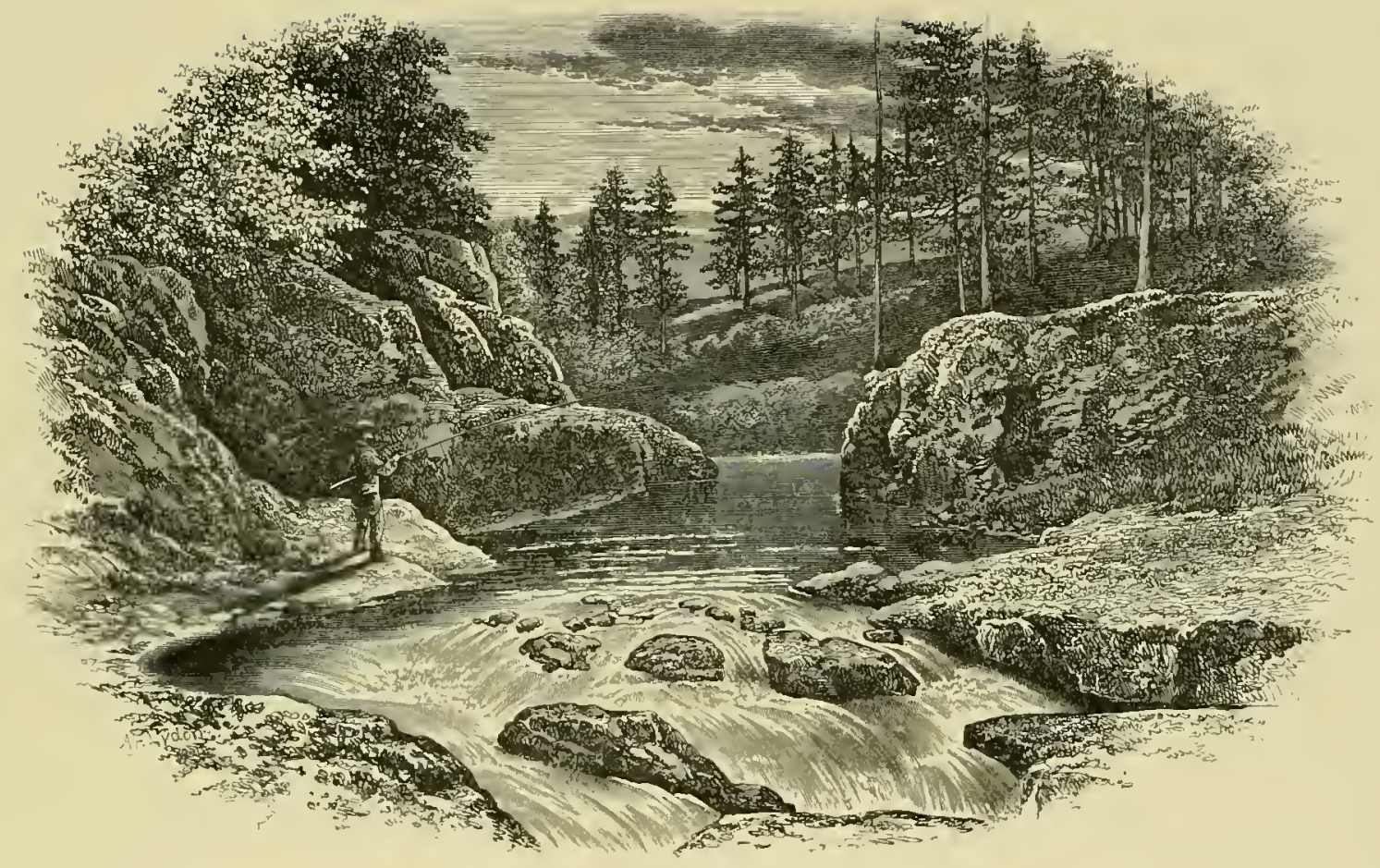

ON THE Devon, Scotland.

Order $I V$.

PHISOSTO.11I.
Family

SALMONIDE.

Sub-generic Group-SALMONES.

\section{Short-headed Salmon.}

(Salm, brachypoma.)

THIS is another well-marked species, for which we are again indebted to Günther. My 1 efforts to procure specimens of this fish, I am sorry to say, failed; I have, however, been able to examine this species, through the kindness of Dr. Günther, in the British Museum. It is a migratory Salmonoid, like the rest which have at present come under our consideration: and is found in the rivers of the Tweed, Forth, and Ouse. "It is one of the best marked species of Salmo; its remarkably short head, and the extremely short preoperculum, (see woodcut on page $8 \mathrm{I}$,) renders it one of the easiest of determination; it is evidently nearly allied to the non-migratory species." - (P. 88, Cat.)

The fins in this Salmon are very short and rounded, the tail is truncate in specimens ten inches long, but never becomes convex; the maxillary is not so strong as in $S$. fario (Trout), and extends a little beyond the posterior orbit of the eye; the sides of the body have 
numerous X-shaped marks or ocellated black spots, with red ones along and below the lateral line; the dorsal fin has round black spots; the teeth are strong.

The term brachypoma from Bpaxv, "short," and $\pi \omega \mu a$, "a lid or cover," has reference to the small size of the gill-cover.

This fish grows to a considerable size, the largest specimen in the British Museum is thirty inches long.

Whether this species is abundant or not I cannot say; nor do I know anything as to the quality of its flesh. I applied to the authorities at the museum in Edinburgh for information as to this species, but nothing apparently was known about it; and there was not a specimen in the collection. I hope to be more successful another year.

The number of rays in the fins is

$$
\begin{aligned}
& \text { Dorsal } 13 . \\
& \text { Pectoral } 14 \text {. } \\
& \text { Ventral } 9 . \\
& \text { Anal } 10-1 \mathrm{I} .
\end{aligned}
$$

The figure is from a specimen twenty-seven inches and a half long, now in the British Museum.

Order 11 : PHISOSTOMI
Family

SALMONID F.

Sub-generic Group-SaLmones.

\section{Silvery SALMON}

\section{(Salmo argenteus.)}

Fario argenteus, La Forelle argentée,

Salmo argenteus,
Cur. and Valenc., Histoire Naturelle des Poissons rol. xxi. p. 294-297, ed. 1828 .

GüNTHER's Cat. vi. p. 86 .

$\mathrm{T}^{\mathrm{n}}$

HIS species is described by Cuvier and Valenciennes as having the form of a Salmon, and being in colour greenish, approaching olive grey on the back; the sides and the belly have a bcautiful silvery brilliancy; the size of the specimens shown in the Paris markets is sometimes as much as two feet and a half, and it is not uncommon to see specimens two feet long. The Silvery Salmon is a migratory species of the Atlantic rivers of France, occasionally occurring on the coast of England. There is a specimen of a female twenty-six inches long now in the British Museum; it came from the river Rhymney, in Montgomeryshire, and had been kept for a short time in a fresh-water pond. It is a well-marked species, having a remarkably long head, being a fourth of the total length, without caudal; the preoperculum has a distinct lower limb, and its posterior margin waved; the maxillary is very broad and strong, and extends beyond the orbit of the eye; the fins are well developed; the pectorals are very broad and strong, and somewhat pointed at the 
extremity; the tail is truncate in specimens above twenty inches in length; the teeth are of moderate strength; there are conspicuous radiating strice on the lower and posterior margin of the operculum, which has some round black spots more or less numerous; the sides are marked with dark X-shaped spots, and both the sides and the belly are brilliantly silvery.

The fin-ray formula is

$$
\begin{aligned}
& \text { Dorsal } 14 . \\
& \text { Pectoral } 15 . \\
& \text { Ventral } 10 . \\
& \text { Anal } 11 .
\end{aligned}
$$

The drawing was made from a specimen in the British Museum. 




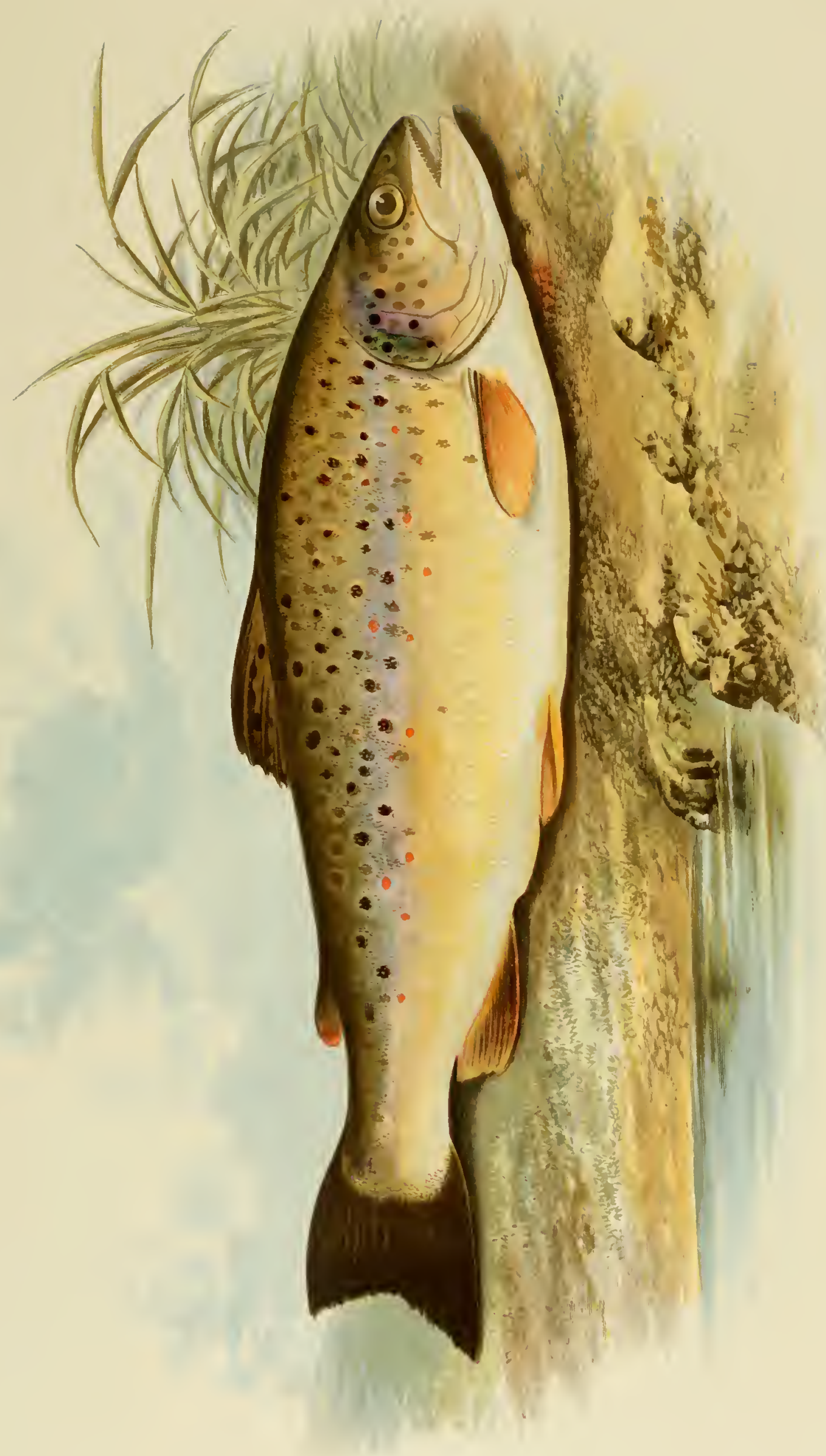




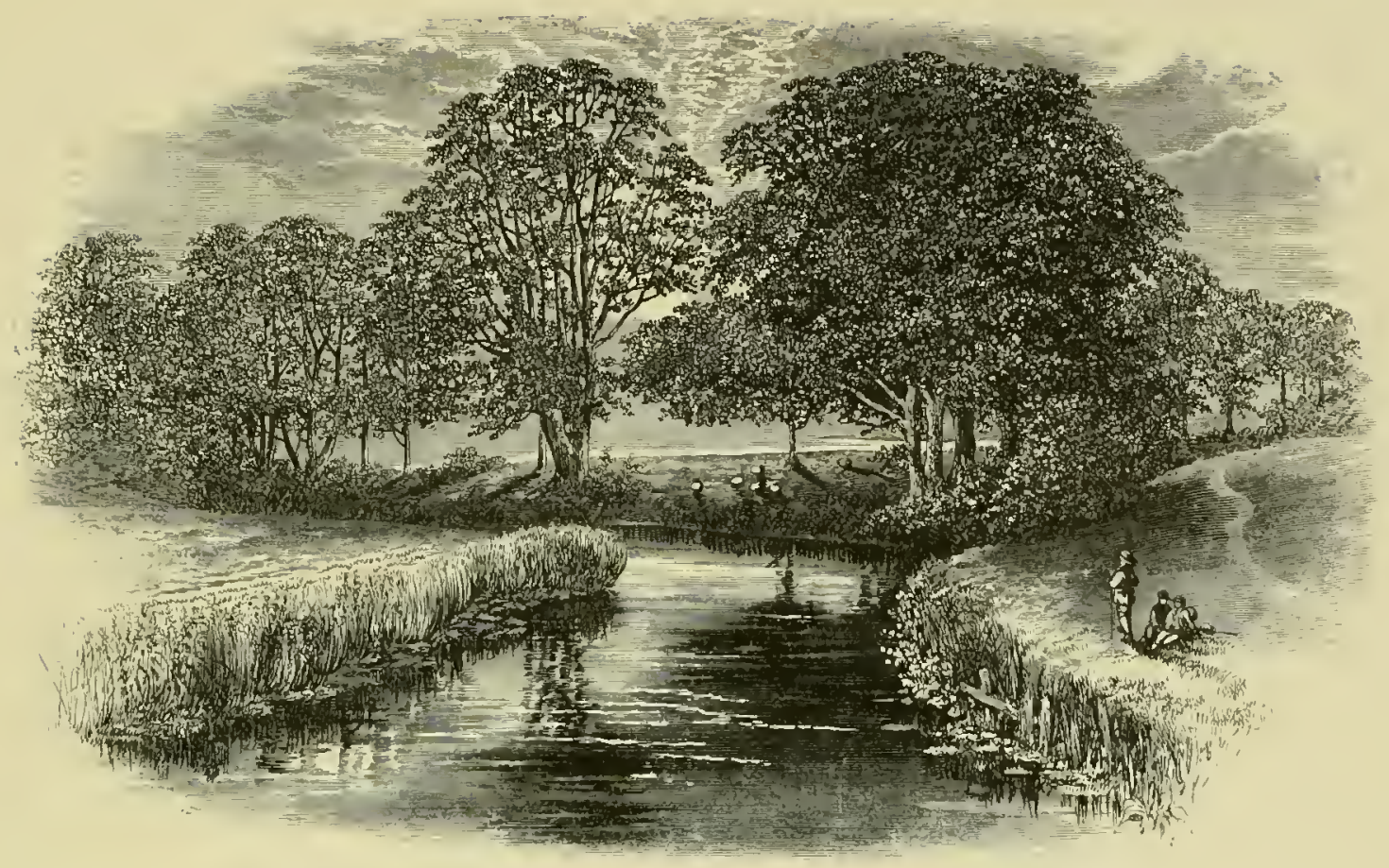

On the Trout Stream, Priffield.

Order $I V$

PHISOSTOMI.

Fimily'

SALMONID X:

Sub-generic group-SALMONES.

\title{
EOMMON 䨖ROUT.
}

\author{
(Salmo fario.)
}

Salar,

Trutta fluviatilis,

salmo, maxilla inferiore paulo longiore, maculis rubris, Sialmo fario,

River Trout Salmon,

Common Trout

Trutta fario,
Ausonius, Id. x. 1.88

Gesner; Rondeletics; Belion; Willughry, p. 199.

Artedi, Spec. Pisc. p. $23, \mathrm{No} 3$.

Lin., Sy's. Nat. p. 509; Donor., Brit. Fish. iv. pl. 85; Flem., Brit. Anim. p. 181; Jenyss' Man. 1\%. +24; Yarrell, ii. 1) 85 ; GüNTHER's Cat. ri. p. 59.

Pennant, Brit. Zool. iii. p. 408 , ed. $18 \mathrm{Iz}$.

Couch, Fish. Brit. Isl. iv. 1) 225.

Siebold's Süsserwasserf. p. 319 .

" T $\mathrm{T}$ is a matter of surprise," says Pennant, "that this common fish has escaped the notice 1 of all the ancients, excepting Ausonius; it is also singular that so delicate a species should be neglected at a time when the folly of the table was as its height, and that the epicures should overlook a fish which is found in such quantities in the lakes of their neighbourhood, when they ransacked the universe for dainties. The milts of Murcuc were brought 
from o:xe place; the livers of Sari from another, and oysters, even from so remote a spot as our Sandwich; but there was, and is, a fashion in the article of good living. The Romans seem to have despised the Trout, the Piper, and the Doree; and we believe Mr. Quin himself, would have resigned the rich paps of a pregnant sow, the heels of camels, and the tongues of flamingoes, though dressed by Heliogabalus' cooks, for a good jowl of Salmon with lobster sauce."-(P. 399-400, ed. 18 г 2.)

Ausonius is very brief in his notice of the Trout; he merely mentions its beauty, and makes no allusion to the quality of its flesh as an article of food-

\footnotetext{
"Purpureisque Salar stellatus tergore guttis."

"With purple spots the Salar's back is starred."
}

Ausonius makes use of the term Fario, but it is not easy to determine what species he intended-

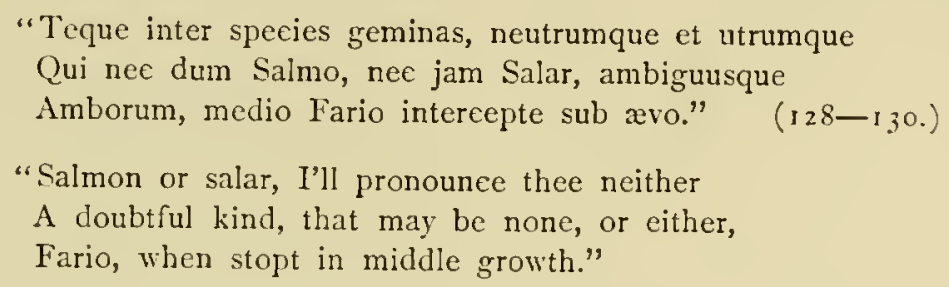

Under the name of Fario, Ausonius may be referring to the grilse state of the Salmo trutta, but it is not possible to speak with any degree of certainty.

If the Salmon be rightly called the King of Fresh-water Fish, the Common Trout may, I think, fairly claim the second place of dignity; for whether we regard the Trout in respect of form and beauty of colouring, or in that of affording most excellent sport, or as a most nourishing and delicious fish for the breakfast or dinner table; in all respects the Trout is eminently good.

The earliest notice of the art of fly-fishing occurs in the writings of Elian, who lived about the middle of the third century of the Christian era. In his chapter De pculiari quodam piscatu in Maccdonia, he gives the following account, which I will translate from the Greek version of Jacobs' edition of the Natura Animalium. I think the fish he mentions are Trout.

"There is a river called Astraus, flowing midway between Berea and Thessalonica, in which

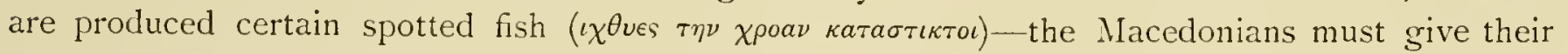
name-whose food consists of insects which fly about the river. These insects are dissimilar to all other kinds found elsewhere; they are not like wasps, nor would one naturally compare them with the flies called cphomira, nor do they resemble bees, but they possess characters common to all these creatures; for they are as impudent as flies, as large as the anthidon, of the same colour as wasps, and they buzz like bees. The natives call this insect the hifpurus. As these flies float on the top of the water in pursuit of their food, they attract the notice of the fish, which swim upon them. When a fish spies one of these insects on the top of the water, it swims quietly underneath it, taking care not to agitate the surface, lest it should scare away the prey; so approaching it, as it were under its shadow, it opens its mouth and gulps it down, just as a wolf seizes a sheep from the flock, or an eagle a goose from the yard; and having done this it swims away beneath the ripple. The fishermen are aware of all this; but they do not use these flies for bait, because handling would destroy their natural colour, injure the wings, and spoil them as a lure. On this account the natural insect is in ill repute with the fishermen, who cannot make use of it. They manage to circumvent the fish, however, by the following clever piscatorial device: they cover a hook with red wool, and upon this they fasten two feathers of a waxy appearance, which grow under a cock's 


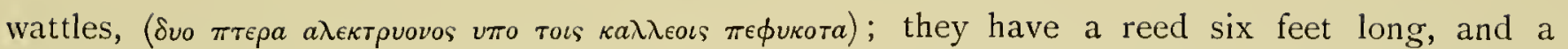
fishing line about the same length; they drop this lure upon the water, and the fish being

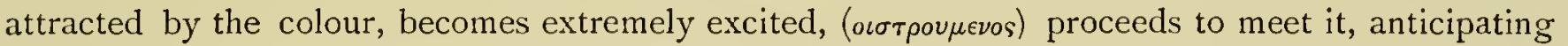
from its beautiful appearance a most delicious repast; but, as with extended mouth it seizes the lure, it is held fast by the hook, and being captured meets with a very sorry entertainment."

"The practice of fishing with a fly," says Couch, "has been thought almost peculiarly English, and of ancient date in this country, and Duhamel in France copies all that he has got to say of it from Walton and Cotton; but in both these particulars there is reason for doubt. The Book of St. Albans gives some directions for what it terms 'dubbing, a practice referred to by Izaak Walton, and which in some distant degree bears a likeness to the modern method of fly-fishing. But neither does this dubbing with a fly obtain a principal place in this old treatise, the very title of which appears to limit it to 'fysshynge with an angle' or earthworm; nor was the patriarch of the art, Izaak Walton, much better versed in it; for it is to his friend Charles Cotton we are chiefly indebted for what afterwards grew to be a new phase in the art."

"The Common Trout," as Yarrell says, "is too widely diffused and too generally known to make any enumeration of particular localities necessary." This is no doubt generally true, nevertheless Trout are subject to great variety, especially in colouration, and some localities are infinitely superior to others as Trout-feeding waters. The Thames Trout are rightly justly celebrated; those of Lough Neagh are not to be surpassed by any fish in the world; the flesh is firm and brick-red, the layers of curd abundant, and I do not think any one can have a good idea of what a Trout is, unless he has handled and eaten the speckled beauties from Lough Neagh. Of the Thames Trout Mr. Manley shall speak:- "I hold," he says, "that a well-conditioned fish of this class is one of the most beautiful objects in animated nature. His symmetry and his colour are unexceptional. He is more beautiful both in form and colour than the most beautiful Salmon that ever ran up fresh from the sea, and when contemplated by his captor immediately on being 'banked,' is a richer feast for the eyes than the prettiest Salmo salar that Hampshire Avon, Severn, Tay, Tyne, Thurso, or Shannon ever produced. Salmo fario of the Thames $\%$. Salmo salar all the world over; the latter charmingly symmetrical and silvery as you will, and beyond compare more beautiful than all silvery fishes; but the former resplendent with all the hues of the rainbow, and others to boot; yet not a mere gaudy creature, like the brilliant fish of the Mediterranean, but with a harmony of bright colours which subdue but do not extinguish one another, and such as no artist could have conceived and few can imitate."-(Notes on Fish and Fishing, p. 13i.)

What Mr. Manley thus enthusiasticaliy but rightly says of the Thames Trout, is every whit true of the Lough Neagh fish of Ireland.

The Trout, though a bold and voracious fish, is at the same time excessively shy, cautious, and cunning; hence great skill and patience are required to insure success on the part of the angler.

The River Trout is, as I have already said, subject to much variation as to colour as well as to small structural differences. Two forms deserve particular attention. One form, with fifty-seven or fifty-eight vertebræ, is found in Central Europe and the southern parts of England; the other, which has fifty-nine or sixty vertebræ, occurs in the northern parts of Europe, some parts of Scandinavia, Scotland, and Ireland. Now these two forms, the one more decidedly northern, the other southern, are thus distinguished by Dr. Günther as Salmo fario gaimardi, and Salmo fario ansonii. $\dagger$ In Cumberland, however, as Dr. Günther tells us, at least

* From the name of a writer, P. Gaimard, author of a work entitled Voyages de la Commission scientifique du Nord pendant les Années 1835-6, $1838-40$.

f From the Latin writer Ausonius, who would be acquainted with the southern form. 
in some of the rivers, as the Caldew and Eden, the southern form occurs, whilst the northern one is found in the river Liddel. "However, the latter extends as far southwards as Shropshire, where both forms are met with. Both are subject to the same amount of variation; but the northern form appears to remain within smaller dimensions. The coincidence of the difference in the number of vertebra with the geographical distribution appears to be remarkable enough to distinguish the two forms; but whether they be regarded as species or varieties is a matter of minor importance."-(P. 59.)

The S. fario gaimardi is thus described by Günther:- "Sides with numerous round or X-shaped markings; the upper surface and sides of the head, the dorsal, adipose and caudal fins generally with crowded round black spots; dorsal, anal, and ventral with a black and white outer edge." This form is the one generally met with in Iceland, Scandinavia, North Britain, Ireland, and Scotland. The Trout of the Clyde is said to form a very well-marked variety, being distinguished by a short body, very short snout, broad maxillary, strong vomerine teeth, small anal fin, and numerous fine $\mathrm{X}$-shaped markings on the body; the spots on the dorsal fin are small, ovate, and numerous.

S. fario ausonii has the "body, head, and dorsal fin with numerous red and black spots; a part of the latter have generally a light edge; the black spots are either round or more irregular in shape, composed of X-shaped marks. The anterior margin of the dorsal and anal, and the outer one of the ventrals generally yellowish. This form inhabits the numerous fresh waters of Central Europe, Sweden, and England, and the rivers of the Maritime Alps."

In Shropshire we certainly meet with both these forms, as well as forms intermediate between them; the margins of the fins being sometimes white and sometimes yellowish.

Trout are inhabitants of fresh water, brackish water, and salt water; as Dr. Günther says, "the water has a marked influence on the colours. Trout with intense ocellated spots are generally found in clear rapid rivers and in small open alpine streams; in the large lakes with pebbly bottom the fish are bright silvery, and the ocellated spots are mixed with or replaced by $\mathrm{X}$-shaped black spots. The brackish or salt water has the effect of giving them a bright silvery coat, without or with comparatively few spots, none of which are ocellated. Now some of the species, like S. fario, inhabit all the different waters indicated, even brackish water, and therefore we find an immense variation of colour in one and the same species."

There seems to be no doubt that the Common Brown Trout, though normally a nonmigratory species, is frequently migratory in its habits, and descends to the sea, where the ordinary brown spots and trout colouration are exchanged for X-spots and a silvery hue. This leads me to notice a Trout, which I think is merely a variety of the S. fario, the Slob Trout, or Tidal Trout, occurring in some localities. I have not had an opportunity of examining these Slob Trout, and have only seen specimens of heads. Mr. Haynes, of Patrick Street. Cork, who knows them well, has sent me a short account of them, which I shall here transcribe.

"With regard to the habits of the "Tidal' or 'Slob' Trout, of which numbers are to be had on the estuary of the Lee and Bandon rivers, I have for very many years been in habit of killing lots of them, and during that time I have never seen, or heard of one being taken above where the tide ebbs and flows. The best, and indeed almost the only time they are to be killed, is from the month of January to that of May; they will not rise readily to the fly, and are very seldom lilled except at night; and then they are taken in good numbers. The best baits known for these fish is the Eel-fry or Elvers, as they are more generally called, also live shrimps, and best of all slob-worms commonly called 'rag-ivorm;' the best places to fish for the Slob Trout are off the bridges in the city of Cork, just under the gaslights, where they can be seen rising at the elvers, which always run on the surface of the water in great numbers, all night long, during the months of January, February, March, and April. When you catch one of these Trout, you could squecze a handful of these young Eels out 
of him, the stomach being distended with them to an unnatural size. The Slob Trout is in its primest condition in January and February, and is then more the shape of a Roach than an ordinary Trout, having a singularly small head, and suddenly swelling out at its base; in fact, a two-pound Slob Trout, in grood condition, seems just as if the head of a half-pound fish had been fixed to it, so unnaturally small does it look. My impression is, that this Trout is a species in itself, and not a cross breed between the White and the Brown Trout; if it were a cross breed, I feel certain it would partake of the migratory habits of both these fish. The colour of the Slob Trout is quite different from that of the Brown Trout; it is a sort of opaque or dirty cream-colour, and a very handsome fish to look at, being spotted with large black and red spots, very much larger than those of the Brown Trout. Where they migrate to in the summer I do not know, for neither are they taken in the nets nor with rod and line. The flesh of the fish may be either a delicate pink or pure white colour, but in either case it is equally well-flavoured, and far superior to either Brown or Sea Trout, or even to the primest Salmon. They give wonderfully hard play when hooked, and consequently very frequently get away from the angler, for it is absolutely necessary to use nothing but the finest tackle even when you are fishing on a pitchy dark night. Their weight varies from half a pound up to four pounds."

I am much obliged to Mr. Haynes for this extremely interesting account, and hope that I may be yet able to get hold of a few specimens, through the kindness of Mr. Haynes, who will, I know, do his best for me, and I trust I may be able to insert a short notice before this work is entirely printed off. I am inclined to think this Slob Trout is a variety, but a well marked one, of $S$. fario; for it is well known that the common river Trout is an inhabitant of brackish water, and also of sea water. Couch has rightly said that the Trouts of our own streams have been noticed many times in the month of May to be quitting the river for the deep Atlantic. "To satisfy myself of this," Mr. Couch adds, "I have procured an opportunity of having them taken in the salt water with a net; and a wellgrown Trout has been brought to me that was caught at a considerable distance from a river or fresh water. Under such circumstances a material alteration takes place in the colour of the fish, which becomes of a rich dark brown, with an aggravation of the other characteristic tints. It is believed that these migratory examples in no long time return to their native river; at which season again their appearance is so changed that they have been judged a distinct species; and we believe that they are the same which Dr. Knox has denominated the Estuary Trout."-(Fish. Brit. Isl. iv. p. 230-23I.)

Where difference in the colouration alone of the Common Trout is concerned, one would have considerable hesitation in accepting such differences as indicating specific distinction. Sir William Jardine has figured some of these varieties in his large work, Illustrations of Scotch Salmonida, where the reader may sez differences in colouration; he draws attention to the fact that a variety of distinct colouring or spotting is confined sometimes to only a single loch of moderate size, while in others it ranges through a series of lochs adjoining each other. "In waters of greater extent again, the varieties in different parts of the same loch are very remarkable. Sometimes, almost every bay has its kind of Trout, and the opposite sides of an island, a few acres in extent, oftentimes afford Trout very different in markings and in quality." It is clear, however, that in some cases, Sir IVilliam Jardine has regarded the S. nigripinnis as a mere variety; a Trout which has, besides a very marked difference in colouration, certain structural peculiarities, which have been justly regarded by Dr. Günther as pointing to a distinction in the species. The figure No. I, from Loch Awe, for instance, plate ii., is, I think, S. nigripinnis, and Sir William's description agrees well with that species.

The culture of Trout, by the artificial impregnation of the ova, and by the preservation of the young fish in small reservoirs of pure water, is now quite an institution in this country, and is most successfully carried on by many private individuals, as well as professional dealers. 
Who was the first to institute the artificial breeding of Trout and other Salmonida, I know not; but it was successfully pursued by a German gentleman of the name of Jacobi sometime about the year 1763 , as may be seen on reference to a translation of that gentleman's paper, which has been given in full by Yarrell, (vol. ii., p. 87-96.) His plan was a very simple one, and in its main features it is in use at the present time. Jacobi had some long wooden boxes constructed with fine gratings at the top and ends; these were partially filled with gravel, and having procured the ripe ova from a female Trout, and impregnated them by mixing them up with the milt of the male, he placed them in the gravel; the box was then put in pure running water, and nature performed the task of incubation. For many years nothing more was heard of Jacobi's piscicultural art, and it was not till the years 1848 and 185 I that the art was revived. In 1848 Gottlieb Boccius wrote "A Treatise on the Production and Management of Fish in Fresh-water by Artificial Spawning, Breeding and Rearing; shewing also the Cause of the Depletion of all Rivers and Streams," (Van Voorst). A short time after this date there appeared a paper in the foumal des Traz'aux de l'Academie nationale, (Paris, i 851), entitled Fécondation artificiclle des Poissons, by two French fishermen, M.M. Géhin and Remy. The matter was shortly afterwards taken up by M. Coste, Member of the Institute, and Professor in the College of France, whose valuable work, Voyage a" Exploration sur le Littoral de la France et de l' Italic, (Paris, I861), is in my own library and before me as I write. This work was published by order of the Emperor, and treats of pisciculture, oyster culture, and other kindred subjects. The result of the whole was that the government granted the sum of several thousand francs, and the establishment at Huningue arose. I need do no more than merely mention a few of the names of persons who have published treatises on the artificial rearing of fish, both on the Continent, in America, and in this country, such as Filippi, Fry, Haxo, Millet, Quatrefages, Sivard de Beaulieu, Marquis de Vibrage, Karl Vogt, W. Wright, Francis Francis, and though last, certainly not least, the indefatigable inspector of our English and Welsh Salmon Fisheries, Mr. Frank Buckland. As a practical breeder of Trout, I know no one more successful than my father-in-law, Mr. Masefield, of Ellerton Hall, Shropshire, who annually rears several thousands of fry, and, with his characteristic generosity, distributes to those requiring them.

The development of the ova is greatly influenced by the temperature; Mr. Bartlett, of the Zoological Gardens, hatched Salmon ova in the short space of thirty days after impregnation, the eggs usually taking from one hundred and fifteen to one hundred and forty days, according to the temperature of the water. The proper temperature of the water should range from $40^{\circ}$ to $45^{\circ}$; Trout eggs at such a temperature would take about sixty days to develope into young fry ready to burst the membranes. Mr. Buckland says, "Lay it down for an axiom that the higher the temperature for the egg, the weaker the fish produced from that egg; everything above $50^{\circ}$ is weakening." -(Fish Hatching, p. I02, London, 1863.)

Trout spawn, as a rule, in November and December, but the spawning time varies, both according to season and locality. Trout eggs have been taken from the fish as late as February; and the lateness in spawning must be taken into account in estimating the age of young fish at a certain time of the year. It appears that Trout do not always mature their ova; that they may miss a year or so. Sterile examples are known to occur, and have frequently been taken. In such cases the Trout are in season in January and February, being excellent food.

It is not easy to ascertain the age to which a Trout may attain. Daniel, in the supplement to his Rural Sforts, mentions a case in which a Trout lived in a well at Dumbarton Castle for twenty-eight years, having been a pound in weight when placed there, and never having increased in size the whole time. As a rule, Trout in such confined places do not grow; but the following narrative, also given by Daniel, shows that a moderate degree of confinement will not limit the growth of a Trout. A certain gentleman had made a stew, in 
which he fed many Trout, one of which, weighing three pounds and a half, had been caught in a river not far distinct; its size and strength soon enabled it to become the master of all the other fish that were in the stew before him. "In about a year this fish, which had received the name of Fuller, and was an object of particular attention, had grown to about nine pounds, five of which had been added to his weight between March and October, at which date its length was twenty-seven inches. Its appetite was great, as was its activity; and the body was beautifully spotted. The food, which was not always abundantly bestowed, was worms, minnows, or the entrails of a calf, finely chopped; but unless much pressed by hunger, it neglected them by day. It is an hour before dark that it begins to move about, and then Fuller begins to exercise his tyranny over the rest. He chooses to feed alone on the food thrown to him, and not at all in haste; but when he looks round all the smaller Trout dart off into their hiding places, at which time he sails round to see that they have all withdrawn, and he repeats the circuit at every little interval of his feeding. About one hundred and twenty-five minnows formed the complement of a meal, and in devouring these, woe be to any one of the smaller tribe that ventured to intrude, except, indeed, a single favourite, which he appeared to have selected for a companion. It was only when the feast was ended that others were permitted to scramble for what was left. The greatest amount of activity was when the wind was brisk. Fuller's fate was at last unfortunate, in being stolen from the stew."

The Common Trout sometimes attains a large size. Thames fish have been caught which weighed fifteen to sixteen pounds, and more. Weybridge, Sunbury, Narlow Weir, and Richmond are mentioned as some of the best localities for Thames Trout. I have alluded before to the Lough Neagh fish; having been caught in the deep waters of the lake in nets, they are brought during the season in great quantities, in boats, to Toome Bridge, County Antrim, and thence are despatched, packed with ice in large boxes, by the railways and steamboats to London, Liverpool, Manchester, and many other large towns. Trout of twelve, eighteen, and twenty pounds are not unfrequently taken.

What produces the beautiful pink or red flesh of a Trout in good condition is at present a matter of conjecture. "Chemistry," as Dr. Günther says, "lias not supplied us yet with an analysis of the substance which gives the pink colour to the flesh of many Salmonoids; but there is little doubt that it is identical with, and produced by, the red pigments of many salt- and fresh-water crustacea, which form a favourite food for these fishes."-(P. 3.) I confess I do not myself feel at all certain on this point.

Monstrosities in Trout sometimes occur. IVe meet with young fish with two heads, with humped backs, with their bodies twisted round their umbilical vesicle; Siamese-twin fish, with one tail, and one umbilical bag between them, etc. Generally these "monstrosities" live but a short time. The deformed Trout, however, whose figure-head is given by Yarrell, sometimes grow to half a pound in weight. The head is short and round, and the upper jaw is apparently absent; the lower jaw projects considerably beyond the truncated upper, causing the fish to have a very unsightly appearance. Mr. Yarrell's specimen was from Loch Dow; I learn from Mr. Haynes, of Cork, that similar deformed Trouts have been killed by him in County Cork and County Clare; he has sent me an ink sketch, which exactly resembles Yarrell's woodcut, only the upper jaw is still more elongated; Mr. Haynes has seen three specimens of these fish.

The two forms of Salmo fario have already been mentioned.

The fin-ray formula is, according to Günther,-

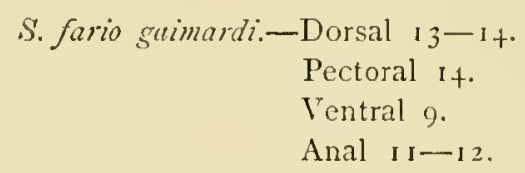

The pyloric cxca are $33-46$. Verlebra $59-60$. 
S. fario ausonii.-Dorsal $13(-14$.

Pectoral 13.

Ventral 9.

Anal I0-II.

The pyloric cxca are $38-47(-51$.$) Vertebræ 57$, counting the last rudimentary caudal, 58 .

The specimen which afforded the illustration was taken in the Trout streams at Driffield. 



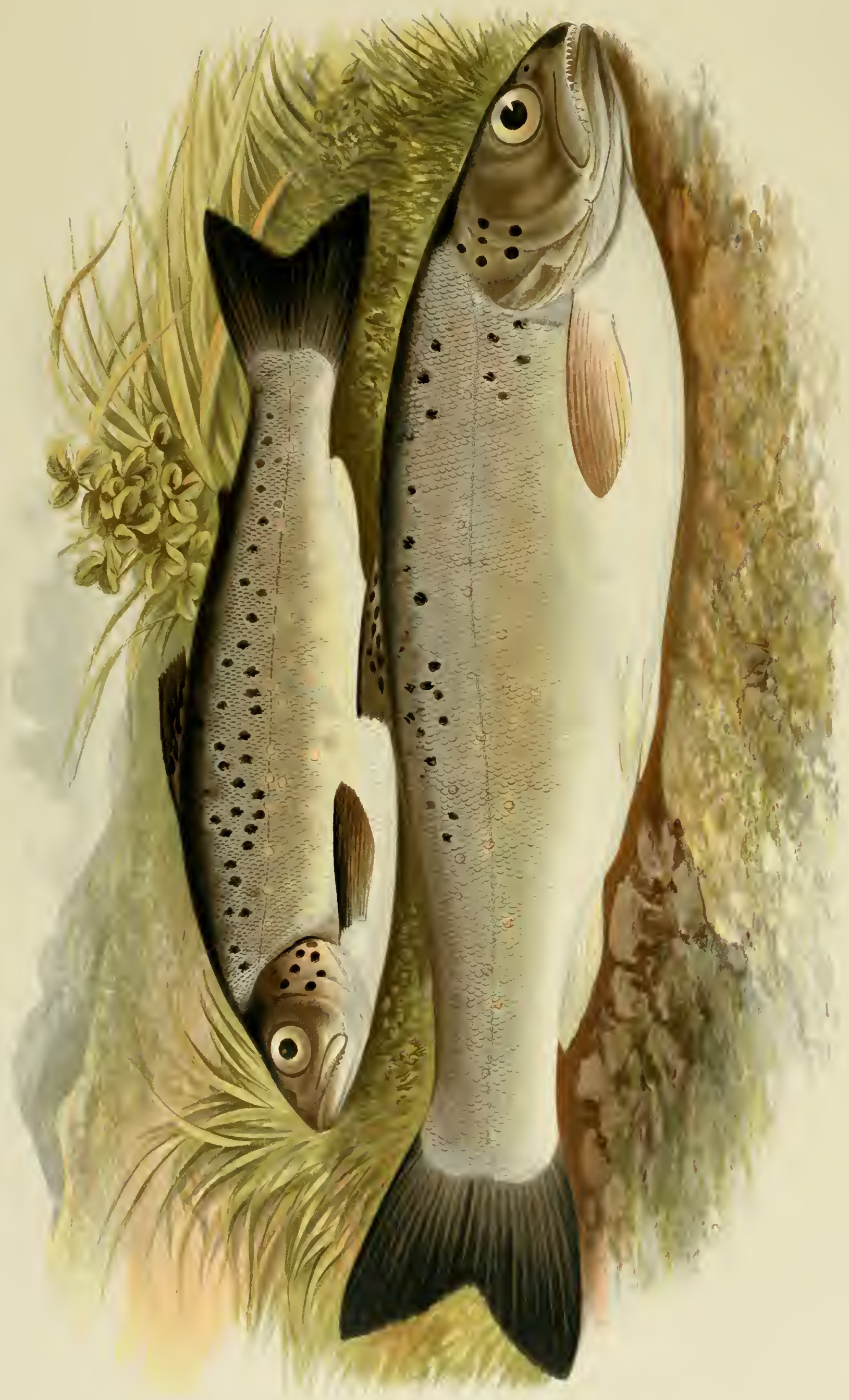




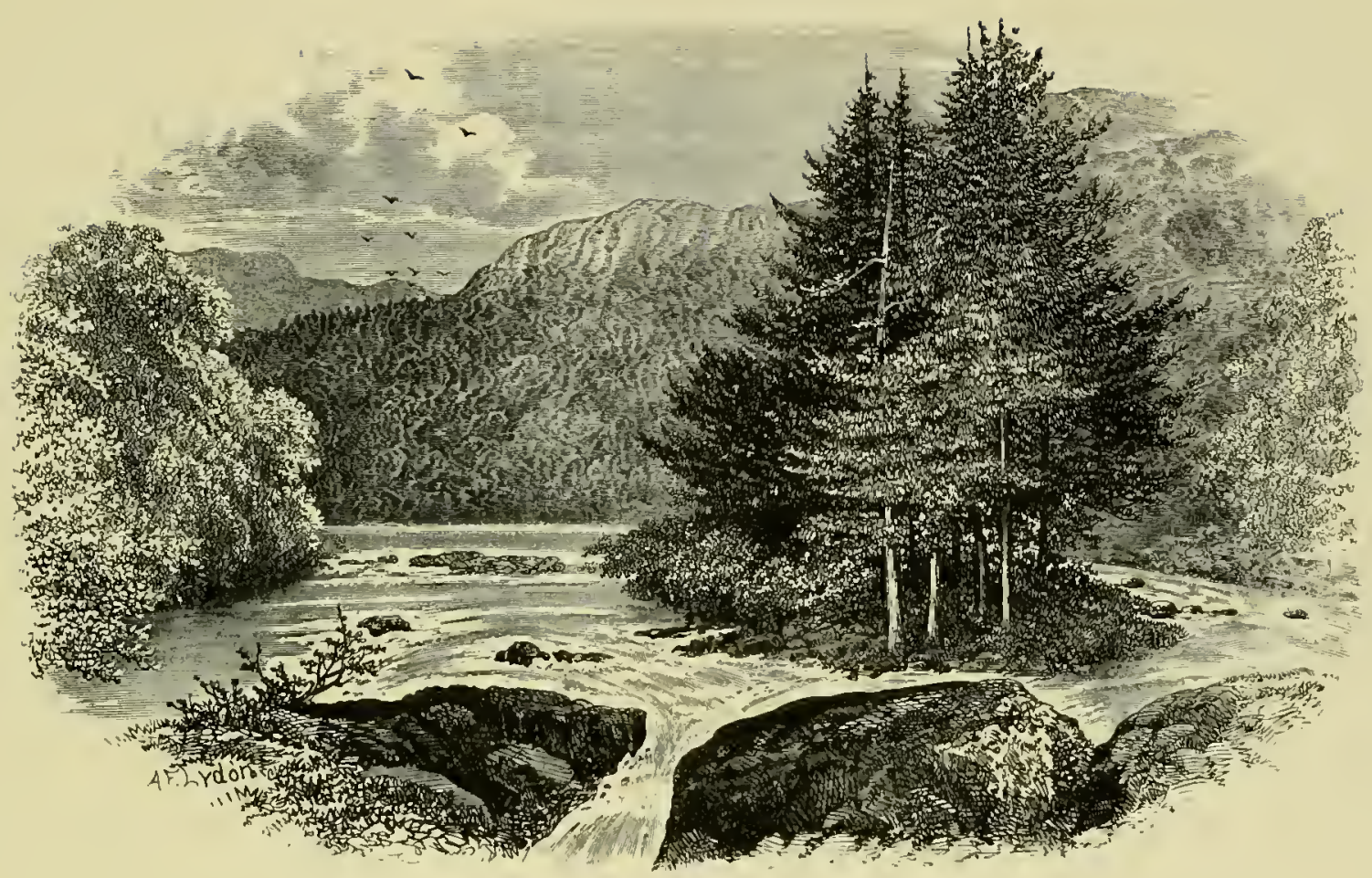

On the Llugwr, North Wales.

Order $I F$.

PIIISOSTOMII.
Fiamily

SALMONIDA.

Subl-generic Group-Salmones.

\section{贯LACK-FINNED 露ROUT.}

\section{(Salmo nigritinnis.)}

Salmu nigrifinnis,

CÜNTHER's Cat. vi. p. 96.

THIS well-marked species of non-migratory Salmomide appears to have escaped the obser1 vation of naturalists, as being specifically distinct from the Common Brown Trout (S. fario), until Dr. Günther brought it into notice. It is clearly distinct from fario in some important structural points; the maxillary in the Black-Fin is feeble, that of the Common Trout is strong; the vomerine teeth are in a single series, in the Trout they are biserial; the pectorals are very long and pointed, the tail is forked or more deeply incised than in specimens of fario of the same size. In colour, moreover, there is great difference between the Black-Fin and the Common Brown Trout; the pectorals, especially in specimens of about seven or eight inches long, are very black, as is also the caudal fin.

1 first made my acquaintance with this very interesting and beautiful species on my visit to Lough Melvin in July, 1878 . The Black-Fin is the ordinary Trout of the Lake, where it 
occurs in greater numbers than the Common Trout; at least my brother-in-law, LieutenantColonel Masefield, and myself caught a great many more Black-Fins than Brown Trout, during our week's visit at Garrison. It was quite easy to fill our baskets with these fish, though a great number were rather small, about eight inches in length. They rise most freely at the fly, are very plucky, and fight strongly to get free; are beautiful in shape and colour; have deep pink flesh, and are unsurpassed as an article of diet for the breakfast or dinner table. I would advise any one who cares more for numbers than size to visit Garrison, where he will be well attended to, in every respect, by Mr. Scott, of the Hotel, and have opportunities of excellent sport with this lively little Salmonoid. The Black-fin occasionally grows to the length of fifteen or sixteen inches, but we seldom took a specimen above ten or eleven inches in length. This species is also found in the mountain pools of Wales, and I have in my possession specimens caught with the artificial fly from a river near Bala Lake, Merionethshire. Dr. Günther mentions the following additional localities for the Black-Fin:-Llyn Beguilin, Merionethshire, Llyn Gadr, Cader Idris, and probably the River Towey, from whence some sterile specimens had been transferred to a fresh-water pond.

The following is a description of a specimen caught by myself in Lough Melvin, Fermanagh, on the I6th. of July, I878. The length was eight inches and a half, the greatest breadth two inches; the length of head was nearly two inches; length of maxillary seven eighths of an inch, breadth a little more than one eighth of an inch; eye large, three eighths of an inch in diameter; irides white; the præoperculum with a rounded indistinct lower limb; maxillary reaching to the hind margin of the orbit of the eye; in larger specimens the maxillary reaches beyond that orbit; teeth sharp, but not so strong as in fario; the teeth of the vomer, as seen in the mouth, appear to be arranged in a double series, but on dissection this apparently biserial arrangement is seen to be owing to the zig-zag disposition of a single series. The pectorals are long and pointed, the outer and inner margins dark; in young specimens, when taken immediately out of the water, they are always almost entirely black. The tail is largely developed and deeply forked, the lobes pointed, and smoky black; adipose fin finely tinged with pink; the dorsal has numerous large oval black spots. Colour of the head on the sides golden yellowish or olive, with several round dark spots on the gill-cover, which sometimes has an elongated silvery blotch: in some specimens these silvery marks are very indistinct or quite absent. The whole length of the back dark with purplish hue; spots large, dark, and reticulated; there are small red spots, sometimes faint in colour, on the lateral line, and a few above and below that line; the scales are small and round, margined with black, silvery in the centre; body full and thick, belly with a yellowish tinge, or white; some specimens have the colour of the body more golden than others. The length of the pectoral is always considerably more than half the distance of its base from that of the ventral; in $S$. fario the length of pectoral is not more than half that distance.

The fin-ray formula is

$$
\begin{aligned}
& \text { Dorsal 12-r3. } \\
& \text { Pectoral 13. } \\
& \text { Ventral } 9 . \\
& \text { Anal I } 12 \text {-12. }
\end{aligned}
$$

I think this species is the one described by Sir William Jardine in his Illustrations; he says that when hooked these fish are very strong and lively, and frequently spring out of the water, that the flesh when dressed is pink and highly flavoured. (See pl. ii. fig. r.) He gives Loch Awe as a locality. I am not sure, however, about this; but in my note-book I have this memorandum made when Sir IVilliam's figure was before me, "surely this is nigripinnis." I am unable to refer again to the Illustrations while writing these remarks. 


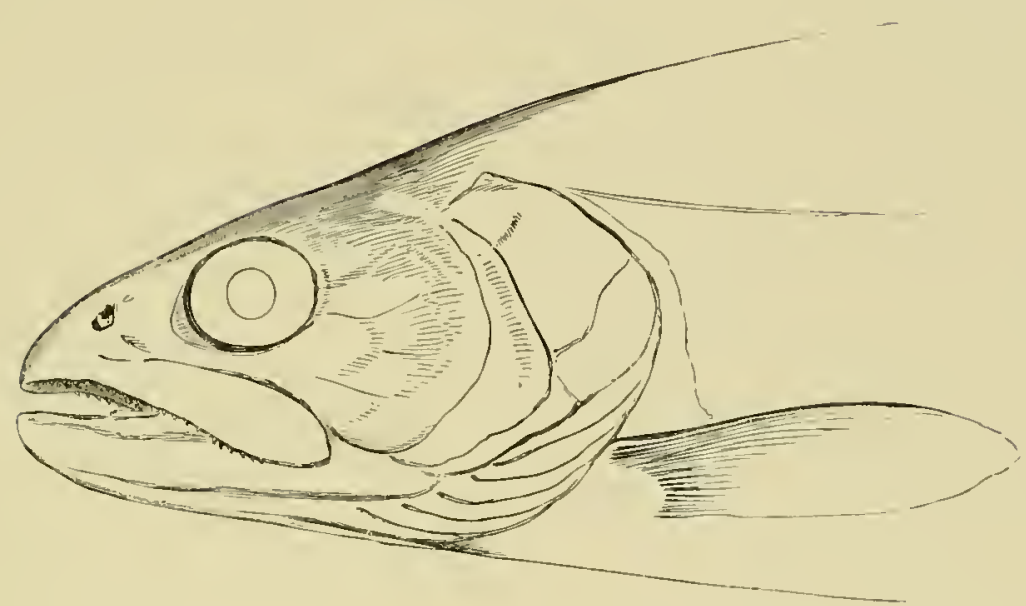

Ortir II:

PHYSOSTOMI.
Family

SALMONTDE.

sub-generic Group-SALMONES.

\section{[ech STENAS ROUT.}

(Salmo creadensis.)

Salmo orcadensis,

Günthlik's Cat. vi. p. 91.

$\mathrm{T}$

HIS species is said to be very similar to S. nigrifinnis, "but distinguished from it by a

broader and stronger maxillary, larger scales on the tail, and a greater number of pyloric appendages." It is thus described by Günther:- "Head well proportioned in its shape, and rather short when compared with the body; body rather slender......Præoperculum with the lower limb very indistinct; snout short, conical. Maxillary as broad and as strong as in $S$. fario; in specimens nine inches long it does not extend to below the posterior margin of the orbit. Teeth moderately strong; those of the vomer form a single series, and are persistent. Fins well developed: pectoral somewhat rounded, its length being more than one half of its distance from the ventral. The caudal fin is distinctly emarginate in specimens nine inches long, but nearly perfectly truncate in specimens twelve inches long: it has the lobes pointed. Scales on the hinder half of the tail considerably larger than on the sides of the trunk: there are about thirteen in a transverse series descending from behind the adipose fin obliquely forwards to the lateral line. Sides with more or less numerous black reticulated spots, between which a few red ones are interspersed. Dorsal with black spots.

Probably a non-migratory species, from Loch Stennis, in the Orkney Islands."

The fin-ray formula is

Dorsal 13.

Pectoral $\mathbf{1} 4$.

Anal 11.

The woodcut is from a specimen in the British Museum. 

"CZ LIBRARY

IA
CAH U UNIVERSITY 


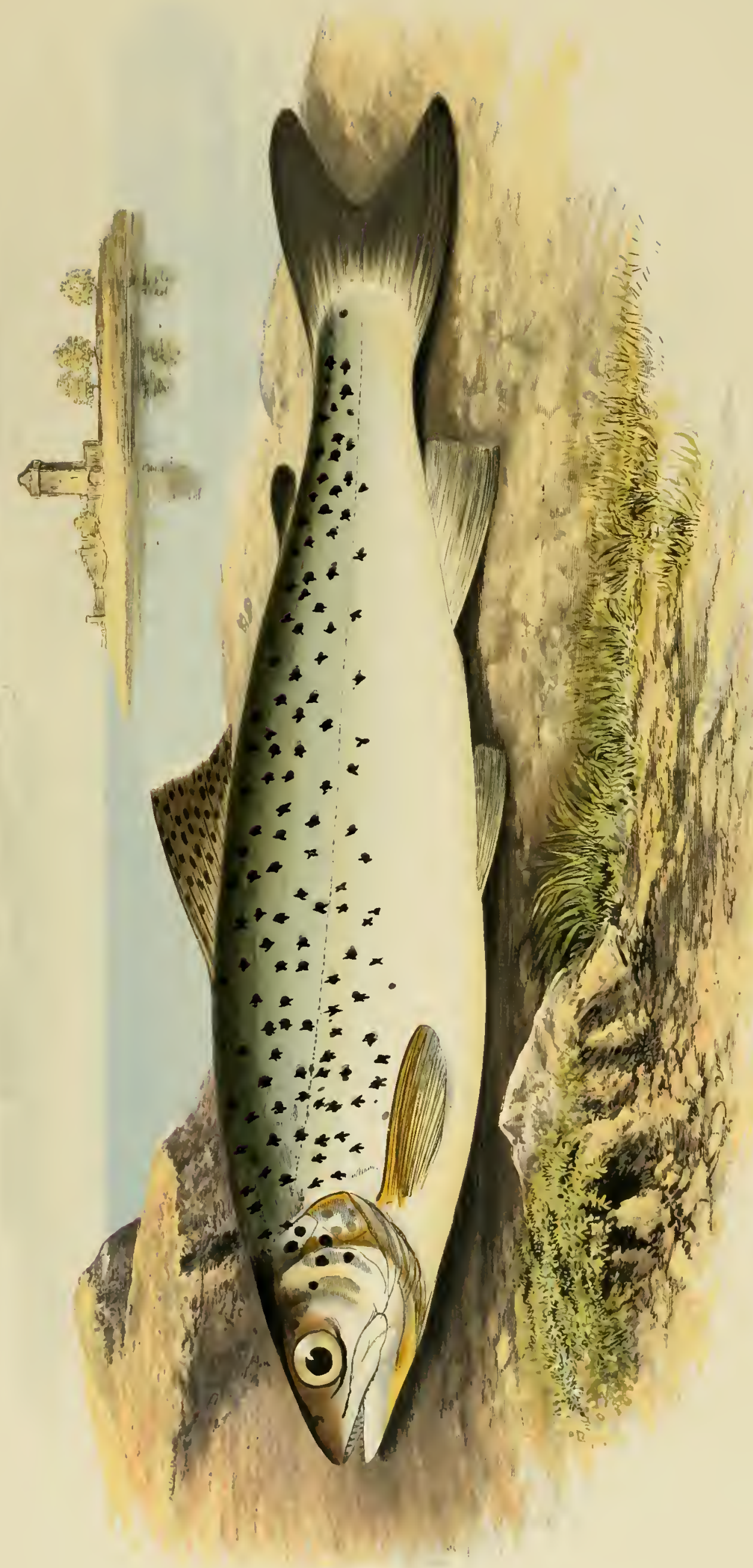




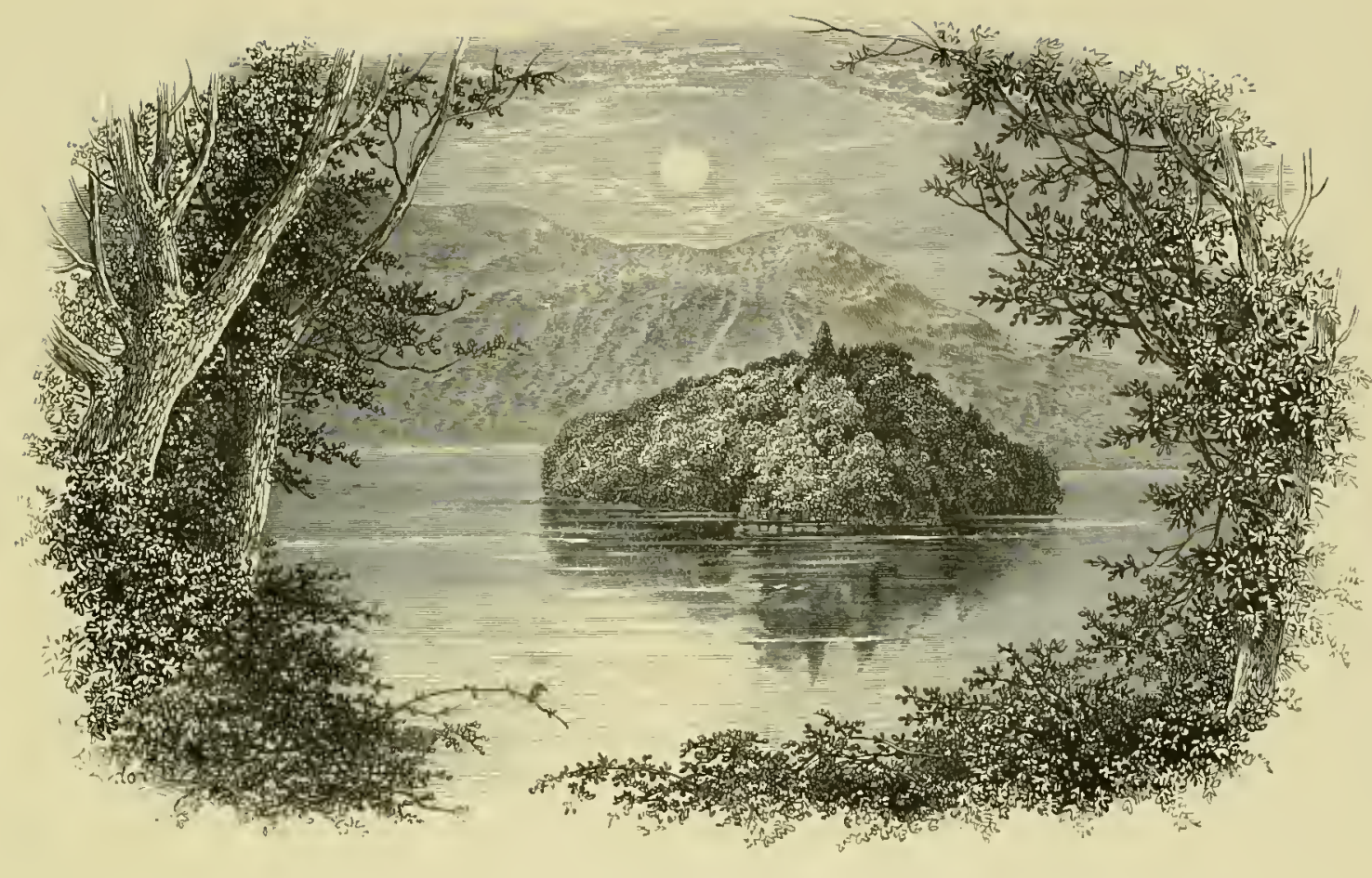

Loch Katrine., Fllen's Jsle.

Order I $\mathrm{IV}$.

PHINOOSOMI.
Family

SALMIONIDA:

Sub-generic Group-SaLMoNES.

\section{霆OCHLEVEN TOUT.}

(Salmo levoninsis.)

Salmo levenensis,

Sulmo cacifer,

Lochleven Trout,
Walker, Wern. Nem. i P. 541; Yarrell, ii. 1' I 17; Günther's Cat. vi. p. ror.

Parnell, Fish. Firth of Forth, Wern. Mem. vii. p. 306.

Richardson, Faun. Bor.-Amer. Pisc. 1) 143: Yarreil, ii. p. 117 : Couch, Fish. Brit. Isl. iv. P. 243 , pl. 220.

THE Lochleven Trout takes its name from the lake, on which stands the ruined castle in which the unfortunate Mary Queen of Scots was imprisoned; but, though this lake is the one most noted for this fish, the Lochleven Trout occurs also in Loch Scone, the river Forth, and a branch of Loch Lomond; the Lake of Windermere and the Rothay river are also mentioned as localities by Dr. Günther. "It has been supposed," says Couch, "that this is one of the many varieties in which the Common Trout is prone to appear, as influenced by differences in water and food; but observers who have been well qualified to form an opinion, such as Dr. Parnell, Mr. Yarrell, and Sir John Richardson," (to which names I may add that of Günther), "have confidently decided that it is a distinct species. From several particulars 
which they have brought forward in support of this conclusion, we feel no hesitation in adopting their decision; and so much the rather as it is shown that there are abundance of the ordinary Trout in the same waters, exposed to the same influences, but from which the species above mentioned is readily to be distinguished."

The Lochleven Trout, so long justly celebrated, are stated by Dr. Parnell to have fallen off in their general flavour and condition, owing, it is said, to the partial draining of the loch having destroyed their best feeding ground, by exposing the beds of fresh-water shells, which form the greater portion of their food. Parnell's prize essay was published in 1837 ; so his remarks may not be applicable now as to the condition of the Trout. Some years ago Lochleven Trout occasionally found their way into the markets and fish-shops of our large towns; but this is not the case now. Accounts of the results of fly-fishing in Lochleven frequently appear in the pages of The Field and Land and Watcr, the well-known weekly periodicals, and it appears that considerable numbers of Trout are taken with the fly; but as the Common Trout is also found in this lake, one cannot learn what proportion the Lochleven species forms of these captures. The Trout-fishing on this loch is, I believe, now reserved for anglers, and netting is not allowed; consequently none of these fish find their way into the English markets.

According to Dr. Parnell they spawn in January, February, and March. The flesh is said to be of a deep red in colour, and so far as I remember they are excellent in flavour; but I have not tasted a Lochleven Trout for many years. I believe it is a lively fish, and gives excellent sport.

The following are the principal points in which this species differs from $S$. fario:-The cæcal appendages are more numerous, varying from sixty to eighty in number; the body is much less stout than in fario, and the hinder part of the body is more tapering; the maxillary is much narrower and more feeble than in the Common Trout (see woodcut on page 81); the pectoral fins are more pointed; the caudal is more deeply incised, and has the lobes more pointed than in specimens of the same size of fario. There is difference in colour: in levenensis the upper parts are generally olive-green, and the sides, both above and below the lateral line, are marked with a great number of dark spots, some of which are round, and many $\mathrm{X}$ or $\mathrm{XX}$-shaped; there are no red spots, which in fario are general and numerous; the adipose fin has a few brown spots, and is never tipped with red: according to my observations, in the Common Trout this red tip is universal. Mr. Francis Day, who, as is well known, is engaged on an important work on the Fishes of India, has kindly sent me a reprint from the Limnean Society's foumal (vol. xii.) of his paper on "The Introduction of Trout and Tench into India." He says that it may be assumed that the S. levincusis and the Tench have bred in the rivers and tanks on the Neilgherry Hills, in the Presidency of Madras, and thinks that this may eventually prove a success. Specimens of Lochleven Trout, received from Mr. H. S. Thomas, of the Madras Civil Service, by Mr. Day, showed bright red spots on the body. Mr. Day remarks very truly "that the colour of the water, and the soil through which streams flow, exercise great influence on the colours of fishes. The spots alluded to are now black; this is probably due to the fish having been bred in a clear mountain stream, but the result in this instance is most interesting."

This is a non-migratory species, inhabiting Lochleven and other Scottish lakes; also occurring in Windermere, and possibly in other north of England lakes.

The fin rays are

$$
\begin{aligned}
& \text { Dorsal I } 2-13 . \\
& \text { Pectoral } 14 . \\
& \text { Ventral } 9 . \\
& \text { Anal II. }
\end{aligned}
$$

Specimens sometimes attain to the length of twenty inches. 



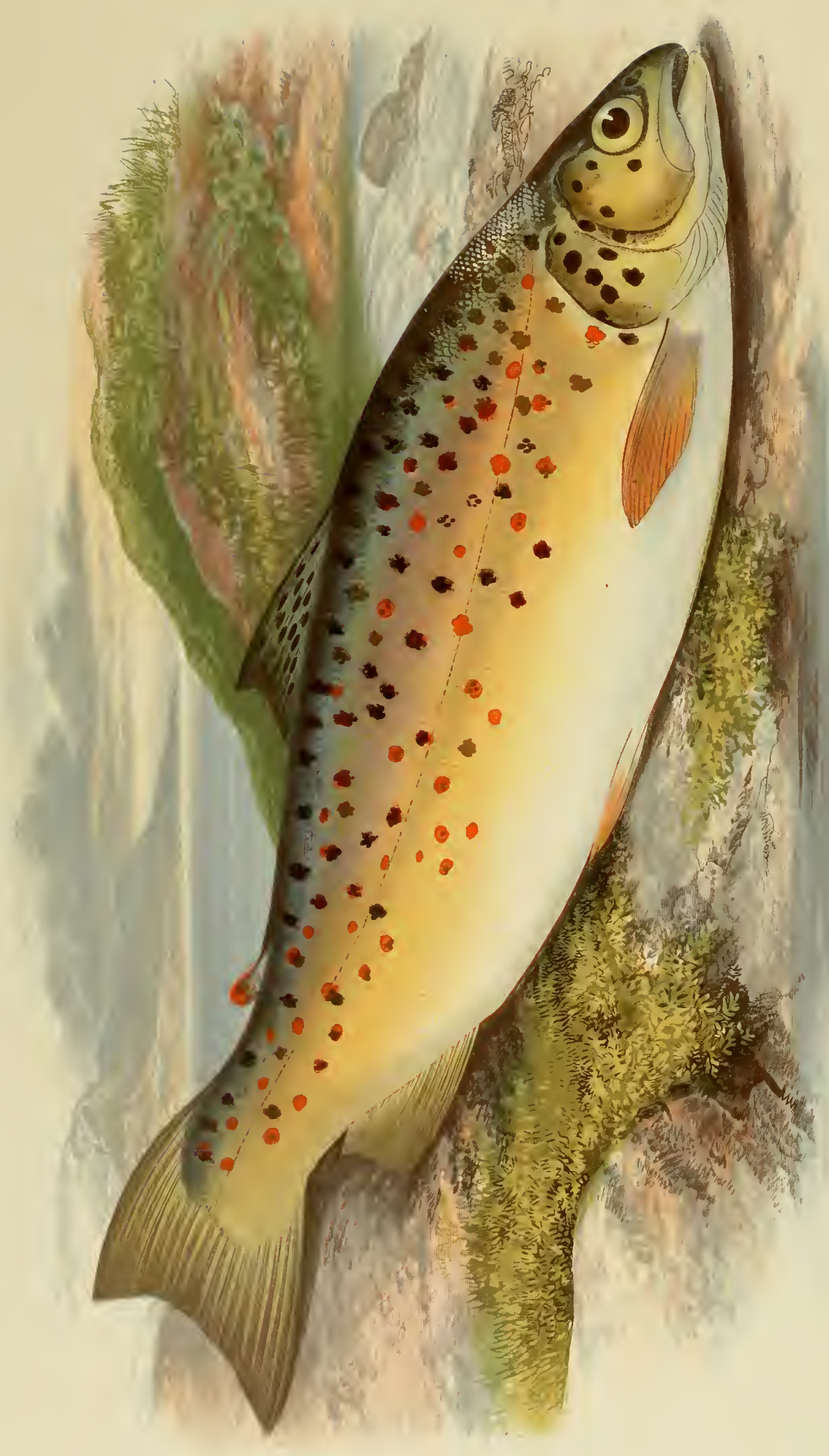





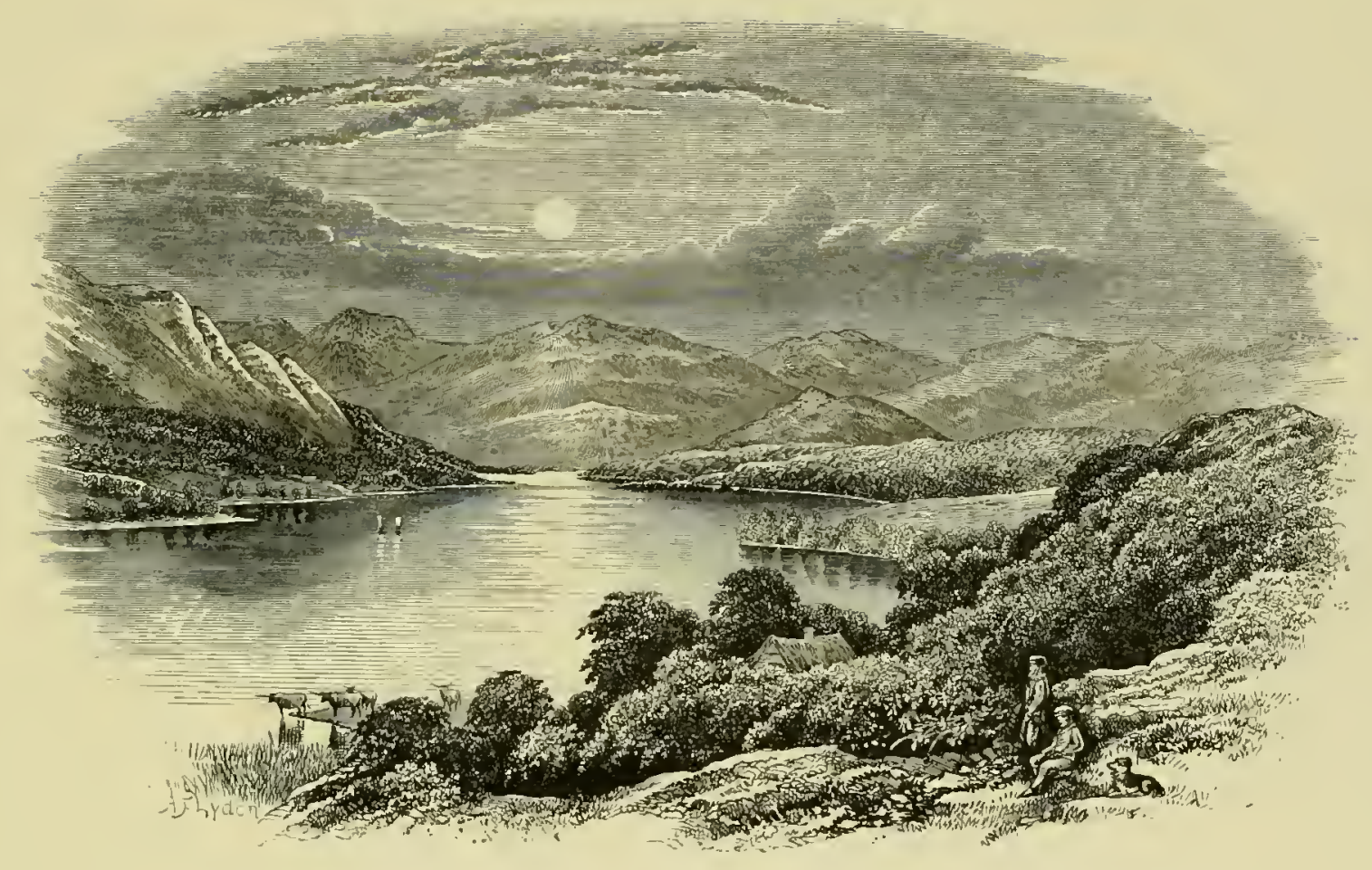

LOCH AWE.

Order $I V$. PHISOSTOMI.

\section{Gillaroo 霞out.}

(Salm, stomaclicus.)
Fimily

SALWOWID E.

Sub-gencric group-SALMONES.

\section{The Gillaroo,}

Salmo stomachicus,
Bikringion, Philosoph. Trans. I 77t, rol. lxiv. p. 1 I6; Watson, Ibid, p. 12 I ; Htnter, Ibid, p. 310 ; Owen, Cat. Phys. Ser. Coll. Surg. i. p. 141; Anat. of Vertebrites i. P. 418; Thompson, Nat. Hist. Ireland iv. p. 154-156; Coucu, Fish. Brit. Isl. iv. p. 240, pl. 249.

GËNTHER's Cat. vi. p. 95 .

TTHE Gillaroo Trout is an extremely interesting species of the non-migratory Salmonida, 1 and beyond all doubt is distinct from the Common Brown Trout, or Salmo fario, in some important particulars. This fish occurs in some of the Irish lakes, as in Lough Neagh, Lough Melvin, Lough Corrib, and Lough Mask, also in the Shannon and the Galway lakes, according to the testimony of Thompson in his work on the Natural History of Ireland. Outside of the Green Island I believe there is no record of its occurrence. I believe the first notice of this Trout occurs in the Philosophical Transactions for 1774.

The thick muscular stomach—on which account Günther has very appropriately bestowed the specific name of stomachicus upon this fish-has been commented upon by that eminent 
physiologist, John Hnnter. The muscular walls of the Gillaroo are so strong that they have been supposed to perform to a certain extent the function of a gizzard. Though such a function was denied by Watson and by Hunter, I think that this organ, with its thickened membrane is, to a small extent, a quasi-gizzard, analogous to that of birds; this is rendered probable from the fact that, in another genus of fishes (Mugil) there exists a modification of the stomach which seems to give it the true character of a gizzard. The essential characters of a gizzard are mainly these two: first, a power and motion fit for trituration, and secondly a cuticular horny lining. Now, Professor Owen has shown that in the Mullets (Mucil) this latter structure does exist in the stomach of the Mullet, as a distinct layer of rough and separable cuticle. "The modification which gives the stomach the true character of a gizzard, is best seen," writes Professor Owen, "in the Mullets, (Mugil). The cardiac portion here forms a long cul-de-sac; the pyloric part is continued from the cardiac end of this at right angles, and is of a conical figure externally; but the cavity within is reduced almost to a linear fissure by the great development of the muscular parieties, which are an inch thick at the base of the cone, and this part is lined by a thick horny epithelium."-(.4nat. of Verteb. vol. i. p. 4 I 8.) With regard to the first essential point-triturating power and motion-there seems to be no doubt that such does exist in the stomachs of some, probably most, fishes. I here quote our great anatomist again. "The muscular action of a fish's stomach consists of vermicular contractions, creeping slowly in continuous succession from the cardia to the pylorus, and impressing a twofold gyratory motion on the contents; so that, while some portions are proceeding to the pylorus, other portions are returning towards the cardia. More direct constrictive and dilative movements occur, with intervals of repose, at both the orifices, the vital contraction being antagonized by pressure from within. The pylorus has the power, very evidently, of controlling that pressure, and only portions of completely comminuted and digested food (chyme) are permitted to pass into the intestine."-(P. 4 I9.) The food of the Gillaroo Trout consists for the most part of various molluscs, which it picks off the rocks and stones in the lakes inhabited by these fish, and there can be little if any doubt, that the strong muscular parieties of the stomach act in breaking up the shells of some of the molluscs on which they feed; and although the inner cavity of the stomach of the Gillaroo is destitute of a thick horny epithelium as seen in the Nullet-for the whole cavity is lined with a fine villous coat-still I doubt not that this organ does possess some power of yrinding.

I have caught in company with Lieutenant Colonel Masefield, several of these fish in Lough Melvin, in July, I878; they are a very plucky fish, and when hooked fight hard to get away. The beautiful bright peach and light orange colour of their sides reveals the species, as it approaches to seize the fly. The Gillaroo proceeds more leisurely and apparently more cautiously than either the Common Trout or the Black-Fin; it seems at first to hesitate at the fly, but turning itself on its side, and at length being satisfied all is right, it rises vigorously, and generally gets well hooked; and if the angler has a good fish, of two pounds or so, on his line, I can assure him, a Gillaroo will give most excellent sport, and where there are weeds, such as the potamogetons with their tough stems, unless the tackle be good, the chances are the fish will succeed eventually in avoiding the landing-net.

The boatmen at Lough Melvin say that the Gillaroo spawns on the shallower parts of the lake, and does not ascend the rivers for that purpose. As to size, the Gillaroo in the Irish lakes often weighs three, four, or five pounds. Thompson was informed that specimens weighing twelve pounds are sometimes taken at Lough Neagh, and Couch states that they have been known to attain the size of nearly thirty inches, with a weight of about twenty pounds. The largest I succeeded in taking did not weigh more than two pounds, but a fish of even a pound weight is quite an angler's prize, owing to the sport which it is able to afford. In memoranda of Mr. Walsh, F.R.S., (Philosoph. Transact., quoted above, p. I 19), dated Killaloe, Oct. Ist., 1773, "Innkeeper's account," it is stated that "the gizzard of a Gillaroo Trout is 
of the size of a large chicken, that it is white and excellent eating, is vastly broader than a Trout of the same length, and that some of the fish are three feet long; some from twelve to eighteen (inches) long; that the Trout itself is bad eating."

The stomach is often much distended with the quantity of molluscous food therein contained, and one can feel the shells within grating against each other, on pressure with the fingers. Besides molluscs, its favourite diet, the Gillaroo will feed on flies of various kinds, such as the Ephimcrida and Phryganida, etc., in their perfect or imago state, and also the larve of various aquatic insects of these and other families of insects. Sometimes the stomach is full of only one species of shell-fish. In the stomachal contents before me, taken from a two-pound Lough Melvin fish, caught by myself with a fly, there is only one species of mollusc in any appreciable quantity, and that is the Limneus pereger, with young specimens of which the stomach was absolutely crammed; in other fish I have found a variety, as Bythimia tcntaculata, Ancyclus fluzintilis, Limncus percger, two or three species of Planorbis, and the curved sand-cases of some of the Trichoptira (the Mystacida and Scricostoma of Pictet).*

The flesh of the Gillaroo is as pink as a Trout in good condition, but neither Lieutenant Colonel Masefield nor myself considered them as nice eating as the Common Trout or the Black-Fin. We thought there was a decidedly molluscous flavour about the flesh; and certainly the examination of a Gillaroo's stomach is, as I know from experience, by no means an agreeable task, owing to the very strong odour exhaled from the swallowed and partly digested shell-fish. "Very hot, Sir," was the remark elicited from one of the boatmen, on my mentioning this fact to him. Thompson, too, says that the fishermen consider the Gillaroo inferior to the other Satmonide for the table. Barrington says that the stomachs of these fish were in his time sometimes served up at table in Ireland under the name of gizzards; I do not know whether such a dish is ever now served up in any part of Ireland.

The following is the description of a specimen caught by Lieutenant Colonel Masefield on July 17th., 1878:- Total length ten inches and a half; length of head two inches and one eighth; greatest breadth of body two inches and five eighths; snout short and convex; maxillary longer than snout, broad and flat, extending a little below the posterior orbit: in smaller specimens it does not extend beyond the middle of the eye; præoperculum with lower limb rounded off; dorsal fin with large oval dark spots, occasionally mixed with a few red ones; pectoral pointed, its length being about one half the distance of its base from that of ventral; caudal fin emarginate: in young specimens this fin is more deeply incised; adipose fin tipped with red; head rather small; gill-cover with numerous round black spots, and with a yellowish tinge; back glossy bluish black; sides of a beautiful apricot above lateral line, shading into a delicate yellow below that line; body covered with numerous large clear black and vermilion reticulated spots; belly white; colour of pectoral and ventral fins deep vivid pink; eye large, irides white. The teeth are feeble: those on the vomer are arranged in a double series, and are persistent through life. The whole body of the fish is full and deep; the hinder part of the tail is also deep.

The fin-ray formula is

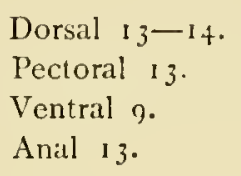

The specimen figured was caught by Lieutenant Colonel Masefield on July 17th., 1878, in Lough Melvin.

* Molluses are frequently found in the stomachs of other species of Salmonida without this peculiarity of that organ; but there is this difference, that in the Gillaroo shell-fish is the usual diet, in other species it is an occasional one. 




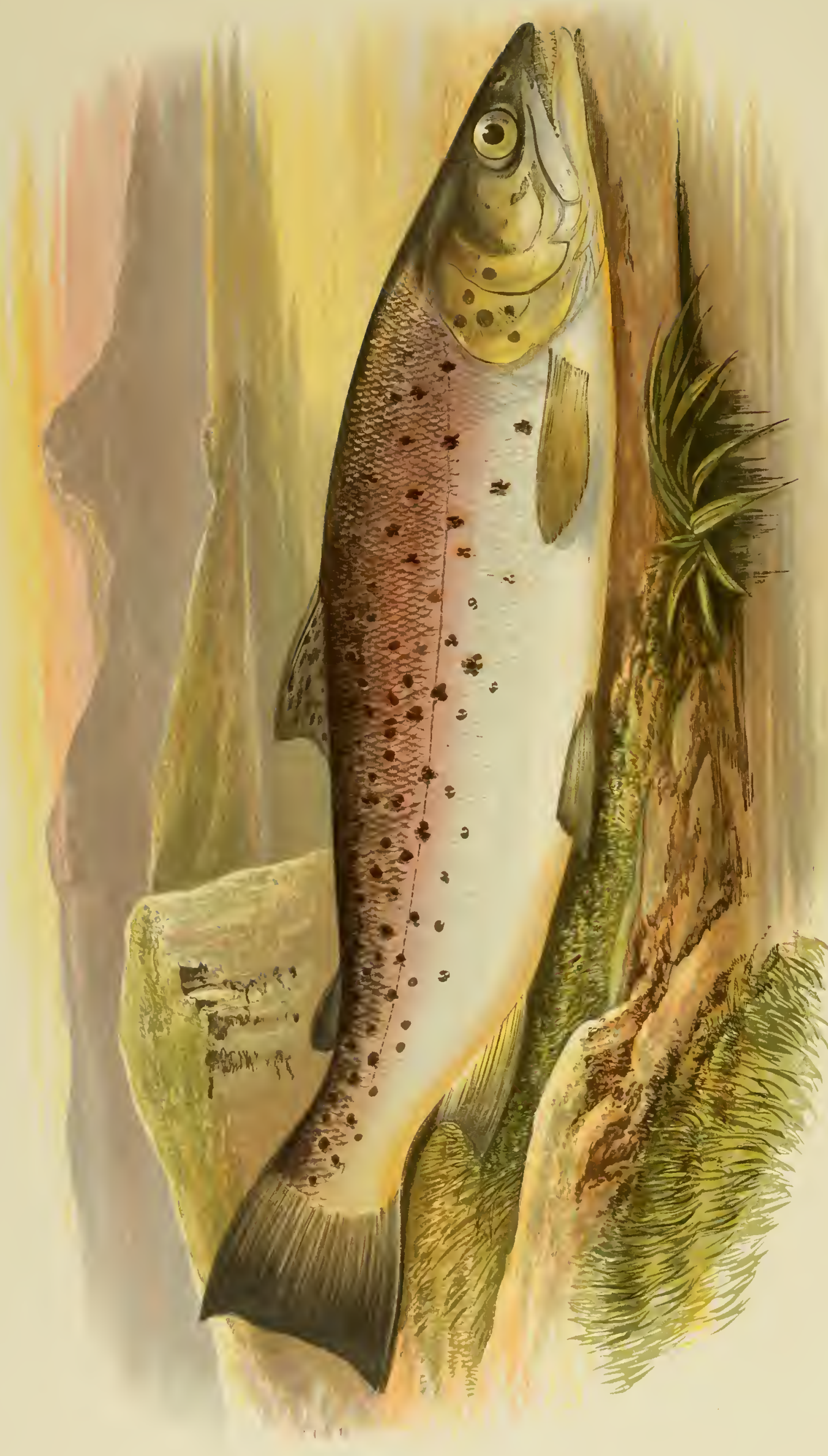

$E$
0
0
$E$ 


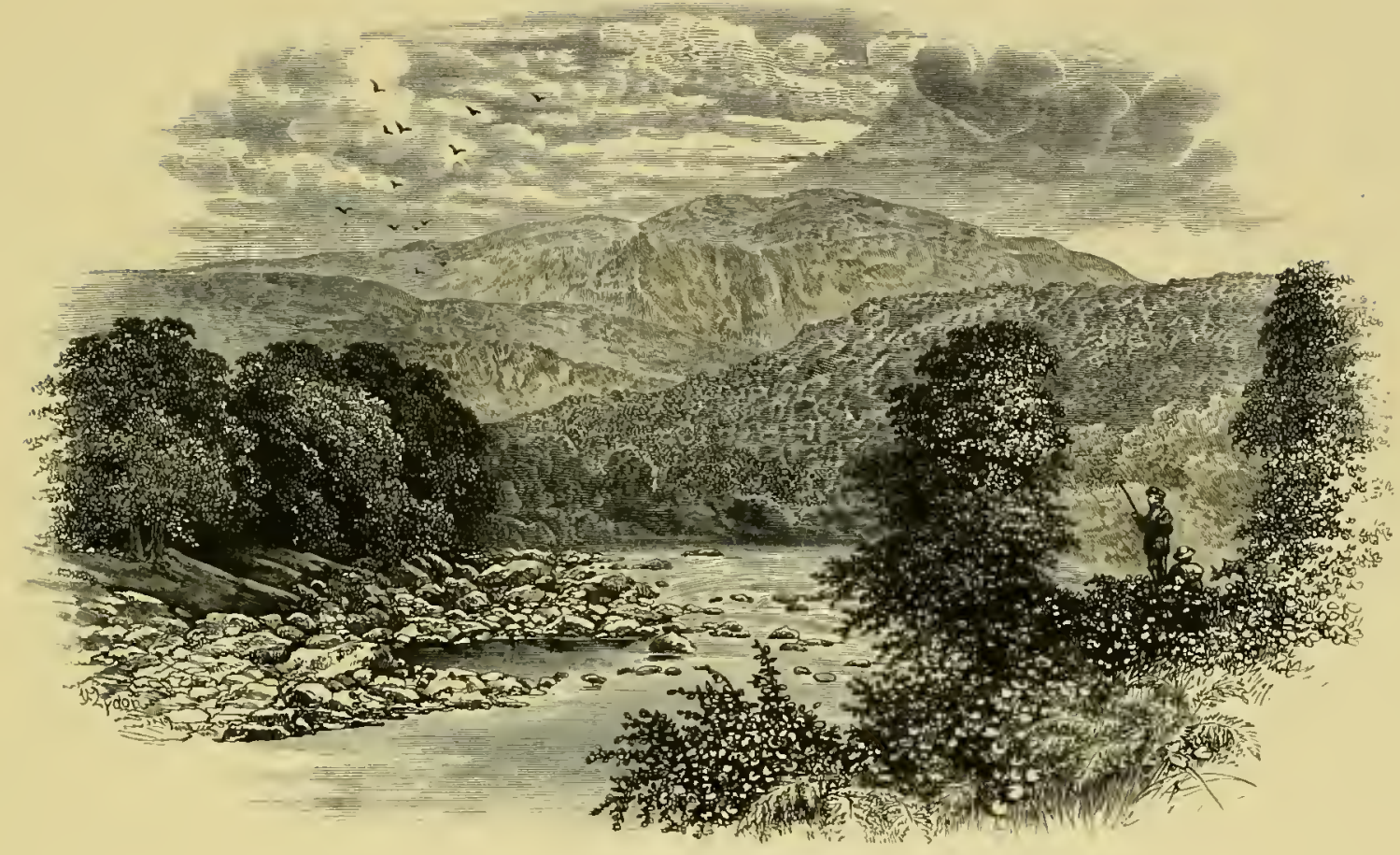

Pass of LENY, TROSSACKs.

Order $I V$.

PHYSOSTOMI.

\author{
Family \\ SALAIONIDAE. \\ Sub-generic Group-SALMONES.
}

\title{
尊REAT 第AKE 需ROUT.
}

\author{
(Salmo firox.)
}

Salmo lacustris,

Salmo ferox,

The Greal Lake Troul,

Lake Trout,

Salar ferox:
Berkenhout, Synopsis of the Natural History of Great Britain and Ireland, 1789 , vol. i. 1. 79 .

Jardine and Selby, Edinb. New Philosoph. Journal, 1835, xviii. p. 55;

JARDine's Illustrations of Scotch Salmonidæ pl. iv.; YARReLl, ii. p. iro;

Richardson, Faun. Bor.-Amer. Fish. p. I 4 ; Günther's Cat. vi. p. 92.

Jenyns' Man. p. 425 ; 'Thompson's Nat. Hist. of Ireland iv. p. 156; Günther's Cat. vi. p. 92.

Couch's Fish. Brit. Isl. iv. p. 222, pl. 217.

Cuv. and Valenc., xxi. p. 338 .

QNE of the first observers to draw attention to the Great Lake Trout appears to have been John Birkenhout, who gave to it the name of Salmo lacustris, as may be seen in his Synopsis, (quoted above); but his description is very brief. He simply writes, (p. 79), Salmo No. 3, "Lacustris, Lake Trout. Sometimes fifty or sixty pounds weight (?). Probably a distinct species. In the North." If this is our Great Lake Trout, then his specific name has the claim of priority; but as the term lacustris is applied to other Salmonida by conti- 
nental writers, it is well to retain the name of ferox, as proposed by Jardine and Selby. "The large Trout," writes Sir W. Jardine, "to" which the above specific designation (forox) was applied by myself and Mr. Selby, had been long previously known and incidentally mentioned by various writers, but it was at the same time confounded with the large Trouts of the lakes of Central Europe, and the distinguishing characters between it and S. fario had not been pointed out. In Scotland it occurs in many of the large lochs, but at the same time it is rather local in its haunts."

The Great Lake Trout is a non-migratory species inhabiting the lochs of the north of Scotland, as Loch Shin and Loch Awe, Loch Laggan, Lochs Loyal and Assynt; it is found also in some of the Irish lakes, as in Lough Neagh, Lough Melvin, Lough Eske, and Lough Erne; in Wales it occurs in the Lake of Llanberris; it is found also in Derwentwater, U1lswater, and perhaps other lakes of the north of England.

This fish is essentially a deep-water species, and only ascends the rivers in connection with the lakes for a short distance for the purpose of spawning, which takes place late in September and in October. The efforts of my brother-in-law and myself, when at Garrison, to obtain a specimen of ferox were fruitless, though we trolled through many miles of water, using a young trout as the bait. It may be that we did not allow the bait to sink deep enough; I am rather confirmed in this opinion by what I have, since my visit to Ireland, read in Mr. Cholmondeley Pennell's work, The Angler Naturalist. As I think his remarks may be useful, I will here quote what he says.

"The only way of taking the larger fish is by spinning with a small parr or other glittering bait towed behind a boat, for which purpose very powerful tackle is required, as the fish is of immense strength, and its teeth as sharp as those of a Pike. As a rule, however, not much success attends the troller for the Great Lake Trout-a circumstance which may possibly be in some measure attributable to the general ignorance of all its habits, and of the manner in which it is to be fished for.

The secret of success lies in four points-time, depth, speed, and place.

Time. As a rule, begin fishing at the time when other people are leaving off-that is, about six o'clock p.m. Up to this hour the fish are rarely in a position from which they can by any accident see your bait. From six o'clock until midnight Lake Trout may be caught. These fish are essentially night feeders. During the day they lie hid under rocks and in holes, in the deepest part of the extensive lakes which they generally inhabit, and only venture into fishable water at the approach of evening.

Dipth. Instead of weighing your tackle to spin at from three to four feet from the surface, lead it so as to sink within about the same distance from the bottom, be the depth what it may.

Specd. Let your boat be rowed slowly, rather than at a brisk lively pace, as a large Lake Trout will seldom trouble himself to follow a bait that is moving fast away from him; consequently your bait must possess the speciality of spinning at all events moderately well, or it will not spin at all.

Place. The place to spin over is where the bank shelves rapidly into deep water, say at a depth of from fifteen to thirty or forty feet, according to the nature of the basin; a much greater or much less depth is useless. This a rather important point, as thereupon it depends whether your bait is ever seen by the fish you wish to catch. The food of the Lake Trout consists of small fish. These are not to be found in any great depths of water, but on the contrary on the sloping shores of the lake, up which, therefore, the Trout comes in search of them, stopping short of the shallows." - (P. 335-336.)

I feel sure that the whole of this advice is most admirable, and I shall certainly put it in practice when I next visit Ireland.

The Salmo forox will occasionally take a fly, and must therefore sometimes swim not very 
far from the surface; a specimen which weighed six pounds and a half was killed on the 2rst. of September, 187t, in Lough Eske, on a fly by Mr. Arthur Wallan; its length was twenty-two inches and a half. Mr. Arthur R. Wallace took last season (1878) on a fly a young Salmo forox, one pound and a half in weight, in Lough Eske. In the landing-net he ejected from his stomach a small Trout five or six inches in length, partially digested. It was a large fish for its captor to swallow, and had been doubled up in the stomach, for which it was evidently too long. Young fish, from one to two pounds in weight, are said to rise more freely to the usual Trout flies; but neither my brother-in-law nor myself succeeded in catching even a young Lake, or as it is called at Garrison, a Black Lough Trout; and I do not think we ever rose one.

When I was at Lough Melvin, the boatmen were particularly desirous that I should secure a Salmo ferox, knowing that I had come not simply for sport, but chiefly for specimens. After many hours' fruitless trolling, at last the line from the reel ran out briskly, and I had "great expectations" that the fish would turn out to be the Great Lake Trout. "Shure, Sir," said one of the boatmen, "it is a Black Loch," on the fish being landed and seen by him. It was really nothing but the Common Brown Trout of about two pounds in weight. "The wish was father to the thought," and I suspect that fish are often taken in Lough Melvin which the non-scientific angler is led to believe to be Salmo forox by the sympathetic boatmen. This feature in the character of the Irish fishermen, for whom I have the greatest respect for their sterling worth, honesty, and good nature, is well illustrated by Charles Kingsley, in his book The Water Babies.

"You must not believe all that Dennis tells you, mind, for if you ask him,

" "Is there a Salmon here do you think, Dennis?"

" 'Is it Salmon, thin, your honour manes? Salmon? Cartloads it is of thim, thin, an' ridgmens, shouldthering ache out of water, an' ye'd but the luck to see thim.'

"Then you fish the pool over, and never get a rise.

" "But there can't be a Salmon here, Dennis! and if you'll but think, if one had come up last tide, he'd be gone to the higher pools by now.'

"'Shure, thin, and your honour's the thrue fisherman, and understands it all like a book. Why, ye spake as if ye'd known the wather a thousand years. As I said, how could there be a fish here at all, just now?'

"'But you said just now they were shouldering each other out of water.'

"And then Dennis will look up at you with his handsome, sly, soft, sleepy, goodnatured, untrustable, Irish grey eye, and answer with the prettiest smile:

"'Shure, and didn't I think your honour would like a pleasant answer." -(P. I30.)

Salmo forox, as its name implies, is a most formidable fish, both from the size to which it attains, as well as from the very formidable armature of its mouth: next to the Pike it is perhaps the most ferocious of the fresh-water inhabitants of our lakes and rivers. Mr. Couch mentions that the Earl of Enniskillen has taken Lake Trout of the weight of twenty-eight and even thirty pounds in Lough Eske. Thompson was informed by a fish vendor that he had frequently in his possession for sale specimens that weighed thirty pounds. In a note Thompson says, "In Sampson's Londondery, the Great Trout of Lough Neagh is said to reach fifty pounds." The fish of this last named lake, I have little doubt, feed extensively on the Pollan, or Fresh-water Herring, so abundantly occurring theie. The largest Common Trout ever caught in Lough Neagh, was taken with a night-line, and a Pollan as a bait; if I remember right, it weighed thirty-three pounds. In Loch Lomond there is a Trout which the people call Powan-eater; - the Scotch Powan is the same as the Irish Pollan (Coregonus follan)-this Powan-eater is probably S. forox. In Ireland the term Buddagh is sometimes applied to this fish. Swift, in $A$ Dialogue in Hibcrnian Style betwecn $A$ and $B$, makes $A$ inquire, "What kind of a man is your neighbour Squire Dolt? B. Why, a mere Buddagh! 
He sometimes coshers with me; and once a month I take a pipe with him, and we shot it about for an hour together." The word Buddagh is said to mean a "big fat fellow." (See Thompson's Natural History of Ireland, iv. p. 158.)

I have never had an opportunity of tasting the flesh of $S$. ferox, and can give, therefore, no opinion as to its quality. The colour is said to be orange-yellow, and the flavour to be coarse and indifferent.

Like some other Salmonida the colour of this fish is found to vary; I do not think, however, that there is a great difference in this respect in the case of individuals inhabiting the same large lake; but where they have been transferred from their natural habitations to small and circumscribed ponds, then there is a marked difference in colouration. A specimen obligingly sent to me by Mr. A. Scott, of Garrison, caught in Lough Melvin, was a handsomely marked fish, as may be seen by the accompanying illustration, while another specimen, which I saw and handled alive in October, 1878, taken out of a small stew in the occupation of Mr. John Parnaby, of Troutdale, Keswick, was quite free from any purplish tint: the back and body were yellowish brown with darker brown round spots, and the belly yellow with a slight tinge of gold. This specimen had been caught in Derwentwater, and had been two years in this little pond, in which weeds grew abundantly; it was occasionally fed with chopped horse-flesh, and was thin and in bad condition; it was twenty-one inches in length.

The following is a description of a young male fish I received from Lough Melvin in October, 1878:- - Total length sixteen inches; greatest depth three inches and five eighths; length of head four inches; the maxillary one inch and five eighths, narrow, and extending beyond the posterior orbit; the preoperculum is crescent-shaped, the descending portion rounding itself off, with scarcely a trace of a lower limb. The pectoral fins in this specimen are long and somewhat pointed, the length is two inches and three eighths, and is more than the half of the distance of its base from that of the ventral; the tail is emarginate; the snout is long; eye long; the whole aspect of the head giving the fish a fierce expression. The colour of the back is dark purplish brown, becoming lighter purple on the sides above lateral line, below this line the sides are silvery, the sides marked with numerous black and brown reticulated spots; there are spots on the gill-cover and on the dorsal fin, the gill-cover slightly tinged with pale yellow; the teeth are strong and sharp; vomerine teeth in a single series, and arranged in a zig-zag form; these teeth are persistent, for in the specimen of a head belonging to a fish which weighed twenty pounds, these vomerine teeth are well seen.

The number of rays in the fins are

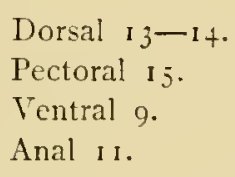

Mr. Alexander Scott, of the Hotel, Garrison, Belleek, Ireland, supplied the specimen from which the drawing was made. 


\section{HARR.}

Characters of the Sub-generic Group SaLvelini.- "Teeth on the head of the vomer only from the earliest age of the individuals."-GÜNTHER.

$7 \mathrm{HE}$ British fresh-water species of fishes which belong to this sub-generic group, comprise

the Charrs, the Smelt, the Pollan, Gwyniad, Vendace (Coregonus), and the Grayling. The three species of the genus Coregonus, however, are destitute of teeth on the vomer, and indeed of any teeth at all. Commercially, this sub-generic group is, comparatively speaking, of little importance; for the Charr are very local, and being inhabitants of deep water, excepting at the spawning season, when they approach the shores of the lakes inhabited by them-at which time they are now protected by the Salmon Fisheries Laws-they are difficult to capture; the Pollan is caught in considerable numbers in Lough Neagh during the spring and summer months, and sent to the markets of Liverpool and other large towns. The Gwyniad and Vendace are known only to a few, and the Grayling is food only for the angler. The Smelt, however, is an exception, and large quantities of this delicate and delicious fish find their way into the markets of all our towns.

Of this group, the Charrs come nearest, both in form and habits, to the non-migratory Salmones. Often beautiful in colouration, and always elegant in shape, the Charrs at once attract the attention and admiration of the beholder.

Much obscurity has hung over the history of these fish, and little was known of either their habits or of the different species which occur in the lakes of Great Britain and Ireland, until Dr. Günther set himself to work out the problem. In a series of valuable papers published in the years 1862, I863, and 1865, in the Procedings of the Zoological Socicty of London, Dr. Günther has contributed a great deal to our knowledge of the British Charrs. From his investigations it appears that there are at least six different species found in the lakes of this country. All these species I have been fortunate enough either to examine or to get possession of. I have also had the pleasure of seeing many living specimens of the Charr of WVindermere, swimming about in the large tanks, belonging to Mr. John Parnaby, at Troutdale, near Keswick, and the opportunity of handling and taking notes of these fish. I have received specimens, in a beautiful condition and perfectly fresh state, of the two Irish species, the Salmo colii from Lough Eske-thanks to the kindness of Mr. T. Brooke, Mr. Arthur R. Wallace, and Mr. Alex. Scott-and the S. grayi from Lough Melvin.

From the secluded habits of the Charr, which frequent the deepest parts of the waters inhabited by them, it is no wonder, perhaps, that little was for a long time known of them Willughby is the first naturalist who has given an account of Charr. The Llanberris Charr, 
which he mentions under the name of Torgoch, "red-belly," he identifies with the Windermere species; from which, however, it is clearly distinct. But Willughby also mentions a fish, which he calls the Gilt Charr, as occurring in Windermere; and says that this fish is very different from the Red Charr, both in colour and in the vomerine teeth; for the Gilt Charr has a white belly. What this Gilt Charr may be I know not, but I think it probable it may be the fish which has occasionally been supplied to Mr. Parnaby, under the name of Silver Charr, which is said to be found in Lake Windermere. Pennant, Donovan, Thompson, Yarrell, and others, have given us notices of Charr, but, as I said before, scarcely anything was definitely known, until Dr. Günther turned his attention to these interesting fish. I will now proceed to a consideration of the different species. 



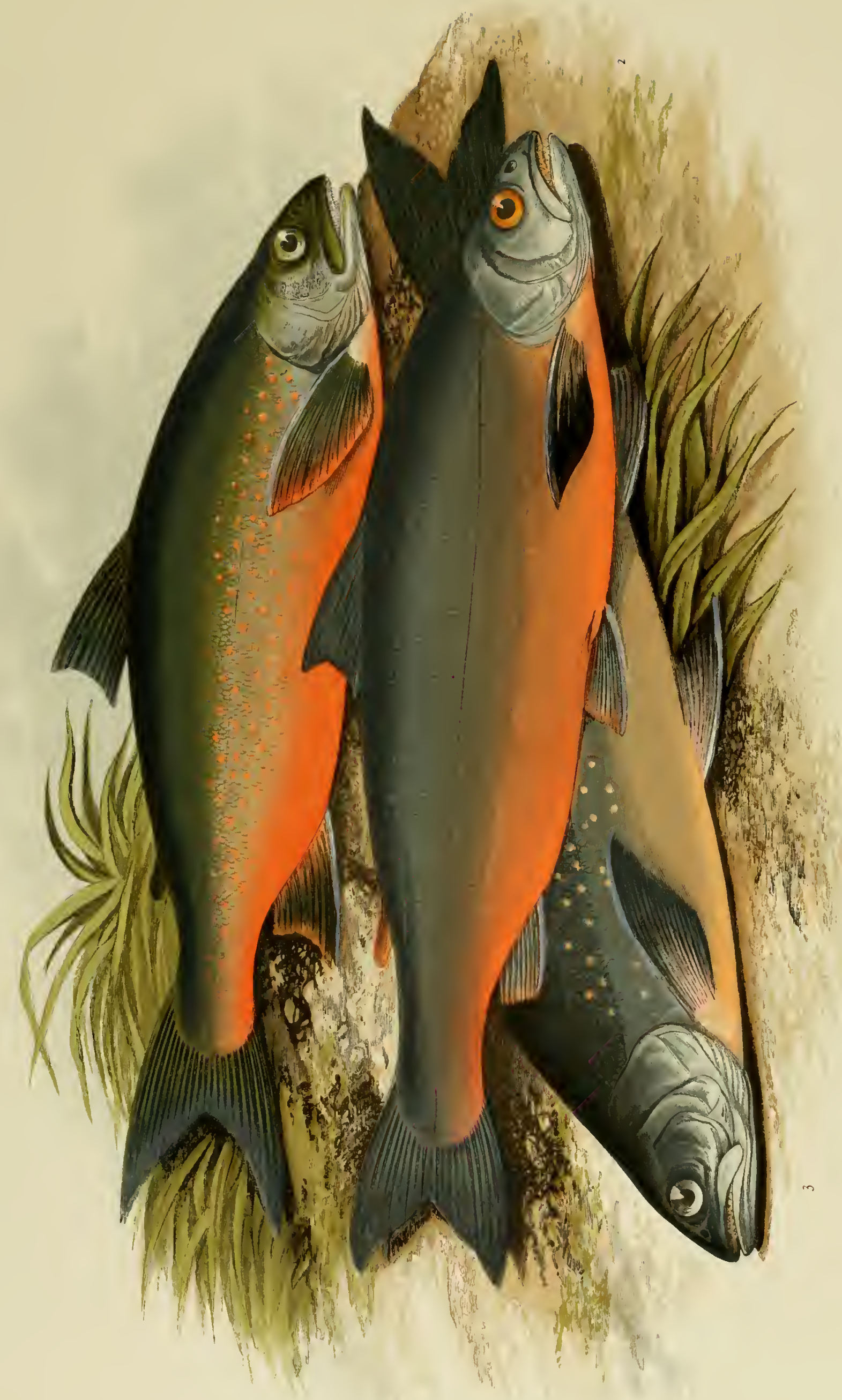




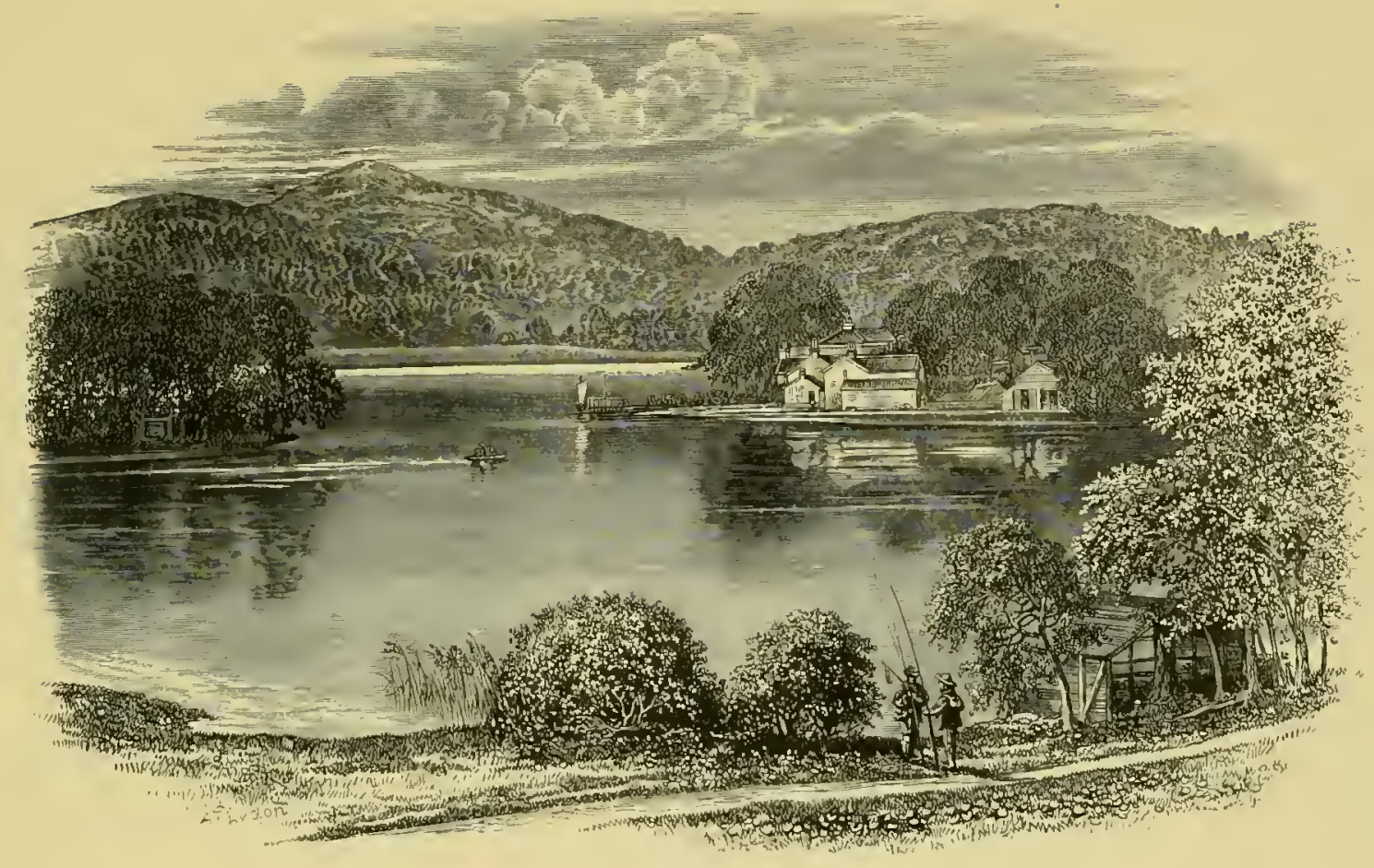

WINDERMERE,

Order $I V$.

PHISOSTOMI.
Family

SALMONIDE.

Sub-generic Group-SaLVELINI.

\section{INDERMERE 畄HARR.}

(Salmo willughbii.)

Torgoch Wallis, Westmorlandis, The Red Charre, lacus Winandermere, Charr.

Willoughby's Charr,

Salmo alpinus,

Salmo umbla,

Salmo Willughbii,
Willughby, Hist. Pisc. p. 196.

Pennant, Brit. Zool. iii. p. 407, (confused with other species); YARRELL, ii. p. I I (similarly confused). Covch, Fish. Brit. Isl. iv. p. 262, pl. 222 (good). Donovan, Brit. Fish. iii. pl. Ixi.

Thompson, Ann. and Mag. Nat. Hist. 1840, vi. p. 439 , (confused with other species,) or Nat. Hist. of Ireland, iv. p. $160-167$.

GÜNTHer, Proc. Zool. Soc. 1862, p. 46 , pl. v. and $186_{3}$, p. I I; Cat. vi. P. 13 I.

$7 \mathrm{HE}$ Charr of the lake of Windermere is the species which is most generally known. It 1 is mentioned by Willughby, Pennant, Donovan, and other writers, as being caught in nets-"retia Trammels Anglice dicta," says the first named authority,-as, being much esteemed for the table, and very delicate when potted. Although Windermere is the lake where this species appears to have its head-quarters, it is found also in other north of England lakes. 
Mr. Parnaby tells me that during the season Charr are taken in Buttermere, Ennerdale, Coniston IVater, and Wast Water; but he does not say definitely whether this Charr is the Windermere species. The same species, or one very closely allied to it, is found in Loch Bruiach in the north of Scotland, as mentioned by Günther. Mr. Parnaby tells me that there are two species of Charr in Windermere, called by the fishermen the Red Charr and the Silver Charr; that they spawn at different times, and under different circumstances. It is possible that this Silver Charr may be the "Gilt Charr" which Willughby says is found in Windermere; but I have been unable to see a specimen of this fish.

Before the application of the Fishery Laws to the capture of Charr, these fish used to be taken in considerable quantities in nets, in the months of October and November, when the Charr seek the shallower portions of the lake for spawning. A few are taken in the summer months by anglers; a writer in Land and Water, a few years ago, speaks thus of the Windermere Charr:- "Though the Charr exists in other lakes of Westmoreland, Windermere is doubtless its head-quarters. The largest Charr I have ever seen exceeded two pounds in weight. Half a pound may be set as about its average full-grown size, though a fish of three ounces will often take the bait. They are bold biters at either the artificial fly or spinning minnow, or the spinning spoon. Though this implies a habit of feeding on the surface, the conjecture that they feed chiefly at the bottom of the water is not thereby refuted, for a practice has lately been introduced oi trailing a revolving bait from a plummet sunk deep in the water, the revolution being kept up in the depths, as on the surface, by the motion of the boat. This fishing for Charr by bait, though the best during spring, is carried on successfully through the whole of the summer. The favourite fishing places are the deepest parts of the lake; an odd fish or two may be occasionally picked up elsewhere, but the knowing hands confine themselves to constantly passing and repassing over the shoal. The Charr come into shallow water to spawn during the autumn, and being then within reach of the nets are destroyed sacrilegiously. They also run up into the rivers to spawn; or, as it would be more correct to say, into a river-for though two rivers fall into Windermere at its head, forming a junction half a mile above the lake, the Charr never go up the Rothay, though myriads turn off at the fork into the Brathay.* Any cause for this preference has hitherto been sought in vain. The rivers run through two neighbouring valleys, the geological formation of which is the same-the ordinary slate-stone of the country. The course of the rivers is of about the same length, and lakes are to a certain extent the feeders of both."

The flesh of Charr, when fried like a Trout, is pink, and I should not know the difference in flavour between Trout and Charr. Potted Charr at Windermere has been an institution for a very long time; the writer in Land and Water, just quoted, says on this subject:"As for any resemblance between the Charr and Trout, the nearest I know of is in the taste, and the public would probably be of the same opinion, if they knew which they are eating under the denomination of potted Charr. The flesh of the Trout may be of as pink a colour as that of the Charr. Both may be alike in season, and of equal flavour, without showing any of that colour. And the red external colour, which the belly of the Charr assumes at the breeding season--the only time at which they are sold for potting-has no colouring influence whatever upon the flesh. The only perceptible difference between their respective flavours must be that imparted by the silver or the gold which they have cost."

Charr, when in perfect condition, and when taken fresh out of the water, are splendid fish, but a correct idea of their beautiful colour can only be formed when seen just out of water. Moreover these fish, when kept in confinement, lose much of their colour. The specimens which Mr. Parnaby has in his tariks at Troutdale, though fine healthy-looking fish, are almost destitute of the brilliant red, characteristic of the fish in their natural habits,

* The same is the case at Ullswater, as I am informed by Professor Busk; Charr invariably ascend one river and invariably avoid the other. 
and when in best condition. The plan adopted by Mr. Parnaby at his fish-breeding establishment, is to place the ova after impregnation, not with gravel in boxes, but between the spaces of slips of glass fitted into an oblong framework, as below, the whole being in a trough,

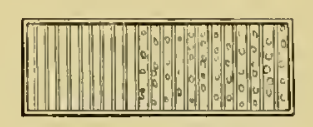

through which fresh water constantly but quietly flows. The advantages of this method are: (1) facility in counting the eggs; (2) easy detection and ready expulsion of blind or unfertilized eggs; (3) the rough edges of the glass enable the young fish to extricate themselves more readily from the egg membrane. In this way Mr. Parnaby succeeds in rearing many thousand young Charr every season; as well as large numbers of that lovely American Charr, Salmo fontinalis, one of the most beautiful of all the species, and one which highly deserves cultivation in our own country.

The Windermere Charr is thus described by Dr. Günther-the two most important points in which this species differs structurally from the allied Welsh species I print in italics. - "Body compressed, slightly elevated, its greatest depth being one fourth of the distance of the snout from the end of the middle caudal rays. Head compressed, interorbital space convex, its width being less than twice the diameter of the eye. Jaws of the male of equal length anteriorly; teeth of moderate strength, four in each intermaxillary, twenty in each maxillary. Length of the pectoral less than that of the head, much more than half the distance between its root and that of the ventral; the base of the fectoral is entirely free, and not ovcrlapped by the gillcover apparatus; the nostrils are situated immediately before the eye; the posterior is the wider, and the cutancous bridge between the two is not developed into a flap. The scales are thin and small, those on the back rudimentary and hidden in the skin. The colour on the sides of the back is a dark sea-green, passing into blackish on the back, on the greater part of the dorsal and caudal. Sides with a slight silvery shade, passing into a beautiful deep red on the belly. Pectoral greenish, passing into reddish posteriorly, the upper margin being white; ventral red, with white outer margin, and with a blackish shade within the margin; anal reddish, with a blackish shade over the whole of the middle, and with white anterior margin; sides of the head silvery, lower parts minutely dotted with black." I may remark that the white margins of the pectoral, anal, and ventral fins are very conspicuous in living specimens of these Charr as seen when swimming in the water.

I am indebted to my friend Mr. T. J. Moore, Curator of the Museum, Liverpool, for a female specimen, eleven and a half inches long; and to Mr. John Parnaby for a male specimen of the same length. Perhaps this s about the ordinary size, but I have seen specimens in Mr. Parnaby's tanks which measured as much as seventeen inches in length. One specimen of about this size had been in confinement eight years; it seemed in good health, but was blind.

Charr love cold water; which, for their successful breeding, should not exceed a temperature of $37^{\circ}$ Fahr.

The fin-ray formula is

Dorsal I 2-1 3 .

Pectoral 13-14.

Ventral 9-10.

Anal 12. 
Order $I V$.

PHISOSTOMI.

\author{
Family \\ SALATONIDA. \\ Sub-generic Group-SALVELIN1.
}

\title{
¿OLE'S EHARR.
}

\author{
(Salmo colii.)
}

Salmo colii, Charr of Lough Eske, Cole's Charr, Enniskillin Charr,
Günther, Proc. Zool. Soc. $186_{3}$, p. 12 , pl. 11 ; Cat. p. 138. Covch, Fish. Brit. Isl. iv. p. 269, pl. 225.

$T_{\mathrm{M}}^{\mathrm{HIS}}$ IIS is one of the smallest, if not the smallest of the British Charrs. I am indebted to Mr. Thomas Brooke, of the Castle, Lough Eske, as well as to Mr. Arthur R. Wallace, of Dublin, for several specimens of this fish, received in November, 1878. Mr. Wallace tells me that he has occasionally taken this Charr with the artificial fly, as when they come from the deep water towards the shore as the spawning season approaches they show in small shoals on the top of the water, somewhat like Mackerel. This species is mature when about five or six inches in length; none of the specimens so obligingly sent to me from Lough Eske exceeded eight inches, and according to inquiries made by the Earl of Enniskillin it never attains to a greater size.

The only known localities for this Charr are the lakes of Eske and Dan. "Lough Eske (Eske or Yesk meaning Fish)," writes Mr. Brooke, whose family have resided near the lake for more than two centuries, "was the crater of an extinct volcano, as suggested by Dr. Wilde, of Dublin; a high mountain range runs close to the north-east shores. In the season Salmon, White Trout (S. trutta), and the Common Lake Trout are in abundance. The Commissioners of Fisheries have decided that the Charr of Lough Eske are the Salmo alpinus, thus placing them in the same Act as Salmon; so that, except for scientific purposes, we are not permitted to take them after August. Formerly, in the months of October and November, the fish were taken in large quantities by the country people, without any apparent diminution of their number. Now, at the permitted season of fishing, they remain in such deep waters that the people have not nets sufficiently large to take them."-(Proc. Zool. Soc. 1865, p. 14.) The Salmon Acts are now applicable to all the species of Charr, which, so long as they continue in force as at present, can never furnish food supply to the people. The extension of the Salmon Acts to Charr is, I think, a great mistake. The only time-and that time is of short duration-when Charr can be taken in any numbers, is in October and November, when they leave their deep-water haunts for the shallower parts of the lakes. The destructive agency of man, limited as it was to one or two month's duration. could have but little effect in causing a diminution of the species, in the extensive depths of our great lakes, which for five sixths of the year provicle safe and unassailable harbour.

The trivial name assigned to this species is intended as a mark of respect to the Earl of Enniskillin, whose family name is Cole, to whom zoological science is considerably indebted for many interesting specimens of natural history which may now be seen in the British Museum. I have to thank the same nobleman for writing me a letter containing information which proved of value to me on my visit to Ireland in July, 1878 . It is much to be regretted that the Earl has now become so blind that he is quite unable to procure speci- 
mens of fish as he once was able to do, both for Dr. Günther and Mr. Couch, in times gone by.

The only localities for this species given by Günther are Lough Eske, County Donegal, and Lough Dan in the county of Wicklow.

The following is a description of a male specimen I received on the 30 th. of October, 1878:- Total length, from end of snout to bifurcation of the caudal fin, eight inches and a half; greatest depth one inch and seven eighths; length of head one inch seven eighths; maxillary rather feeble, extending to the posterior orbit; pectoral fin free from the operculum, acutely pointed, inner margin streaked with vermilion, length one inch and a quarter, considerably shorter than the head; ventral fin red, with distinct outer white margin; anal reddish, with outer white margin; adipose slightly tinged with red; tail deeply incised, lobes pointed and of a reddish tinge; eye large; scales small. Colour of the head deep olive black; back dark, with several small inconspicuous round Salmon-coloured spots above the lateral line; spots below lateral line more distinct; sides brownish pink, or deep roseate hue over silver; under part of jaws whitish; gill-covers somewhat silvery; belly a delicate pink; scales small, but conspicuous. In this specimen the dark parr marks characteristic of the young of the Salmonidæ were visible.

The fin-ray formula is

$$
\begin{aligned}
& \text { Dorsal } 14 \cdot \\
& \text { Pectoral } 13 \\
& \text { Ventral } 9 . \\
& \text { Anal } 12 .
\end{aligned}
$$

Salmo colii is readily distinguishable from $S$. grayi by the comparative shortness of the pectoral fin.

Order II:
PHISOSTONIT.

\section{Family}

$\therefore 4$ LIIONIDE.

Sub-generic Group-Salvelini.

\title{
GRAY'S @HARR.
}

\author{
(Salmo grayi.)
}

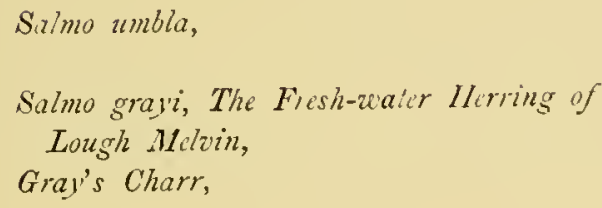

Sizmo zumbla,

Salmo grayi, The Fiesh-water Ilerring of Lough Mclvin,

Gray's Charr.

\author{
Thompson, An. and Mag. Nat. Hist. I840, vol. vi. p. 439 \\ Nat. Hist. of lreland, iv. p. 160. \\ Günther. Proc. Zool. Soc. 1862, p. 51 ; Cat. vi. p. 136 \\ Couch, Fisl. Brit. Isls. iv. p. 267 , pl. 224.
}

I AM indebted to Mr. Alexander Scott, of Garrison, Lough Melvin, for several excellent specimens, both male and female, of this beautiful Charr. They were caught in the month of November; the males had not parted with all their milt, and in the ovaries of the females a few eggs still remained. Little is known of the life history of this species; it appears that the female matures early, and when only five inches long has fully developed eggs of the 
size of a pea. These fish were known to Thompson, who referred the species to the Salmo umbla, Linnæus, and S. salvelinus of Donovan. Dr. Günther, however, has clearly shown that the species is distinct, and he named it after the late kind-hearted Dr. Gray, of the British Museum. When Günther. published his account of this species in the Zoological Society's Proceedings, the female fish was known only by a short notice of Mr. Thompson. I received six female specimens nearly all with a few ova within them, on the 29 th. of November, 1878 , from Mr. Scott; the ova I examined were two lines in diameter. On the 19th. of November, I received from the same source, five specimens which proved to be all males. Of the young of this species I believe nothing is known. Like the other kinds of Charr, the Melvin species is an inhabitant of the deep parts of the lake; a few are now and then caught with a fly in the summer months, but little is seen of them until their spawning instincts lead them to seek the shallower parts of the lake, at which time they have been taken in cartloads. Mr. Scott had considerable difficulty in procuring me the specimens; he had to send to a man at the other end of the lake, who, owing to the storms, had great trouble in setting his nets.

The following is a description of a male specimen received by me from Lough Melvin on the igth. of November. Total length ten inches and three quarters; greatest depth two inches and three quarters; length of head two inches and a quarter; pectoral fin two inches and a quarter, not covered by the operculum; greatest height of dorsal one inch and seven eighths; length of ventral and anal one and five eighths; length of the pointed lobes of the caudal fin two inches and one eighth, shortest caudal ray one inch. Maxillary feeble, extending to the posterior orbit; teeth small. In colour the head is brown; shoulders and back glossy purplish brown down to the lateral line, which rises from the top of the gill-cover, slightly descending, then straight to the middle of the caudal fin, towards which the brown changes to silvery; belly delicate roseate. Above the lateral line there are a number of very small round pink spots, very indistinct. Below lateral line these Salmon-coloured spots are larger and more distinct. Eye large; irides white; prooperculum crescent shaped, rounding off into a lower limb; suboperculum extending beyond operculum; dorsal fin brown; inner base of pectoral tinged with red; ventral reddish brown, inner rays red; anal brown; tail brown, with tinge of olive. Adipose fin membranous, brown; pectoral acutely pointed, a little longer than the head in some examples, and extending as far as, or even slightly beyond the origin of the dorsal fin. I can discover no difference externally in the female from the male of the same size, and caught about the same time. This is a beautiful fish, both in delicacy of colouring and in symmetry of form; the scales are more conspicuous than in other species of Charr. Though somewhat similar, both in form and colour, to Cole's Charr, the species last described, it is readily distinguished from it by the excessive length of the pointed pectoral fin, which in Cole's fish does not nearly equal the length of the head; there is another important difference in the form of the pyloric cæca: in Gray's Charr, the specimen before me, these appendages measure about three eighths of an inch; in Cole's they are about one eighth of an inch, some of them being merely small cylindrical capsules.

The fin-ray formula is

$$
\begin{aligned}
& \text { Dorsal } 13 . \\
& \text { Pectoral } 13 . \\
& \text { Ventral } 9 . \\
& \text { Anal } 12 .
\end{aligned}
$$





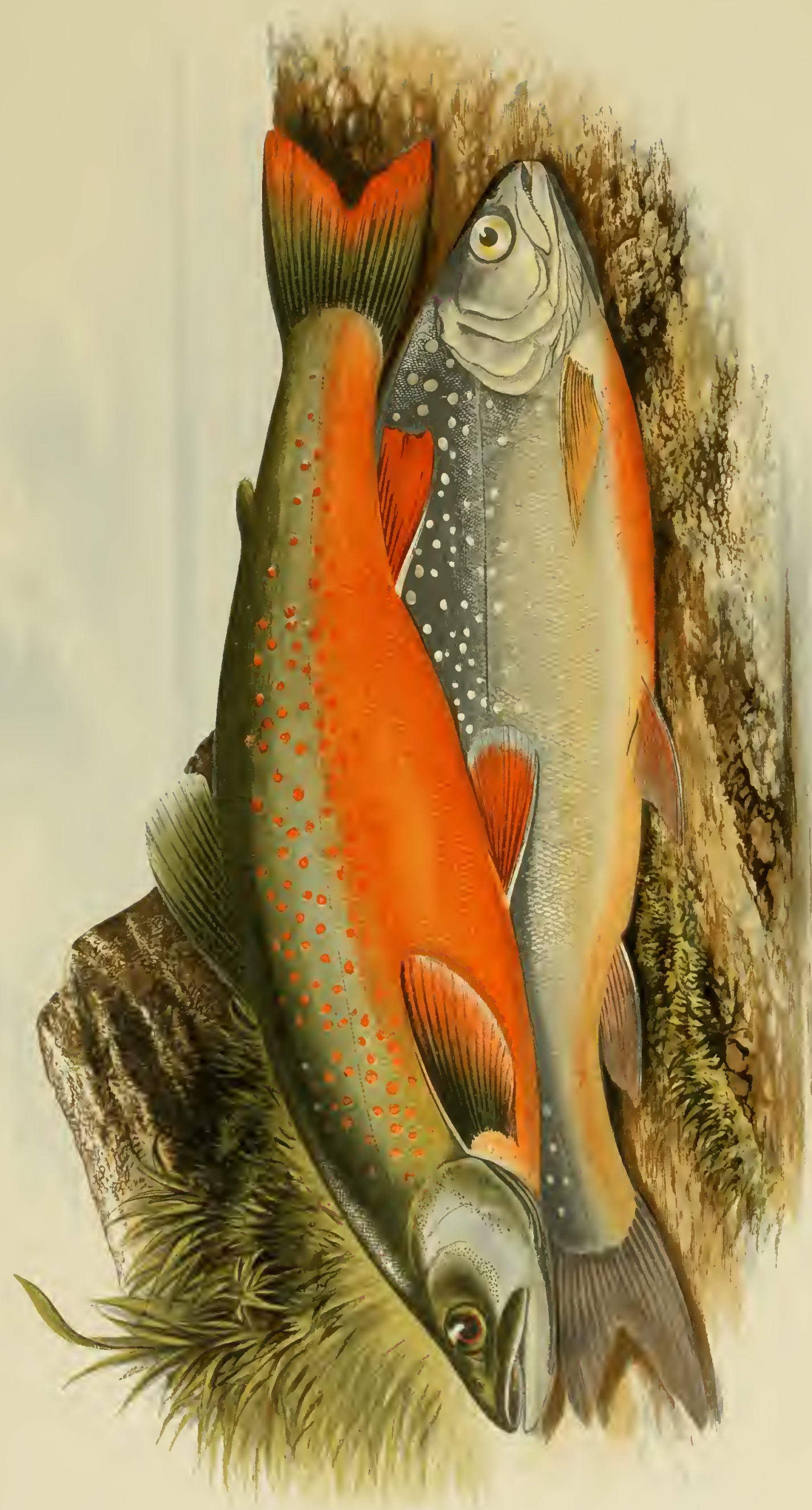




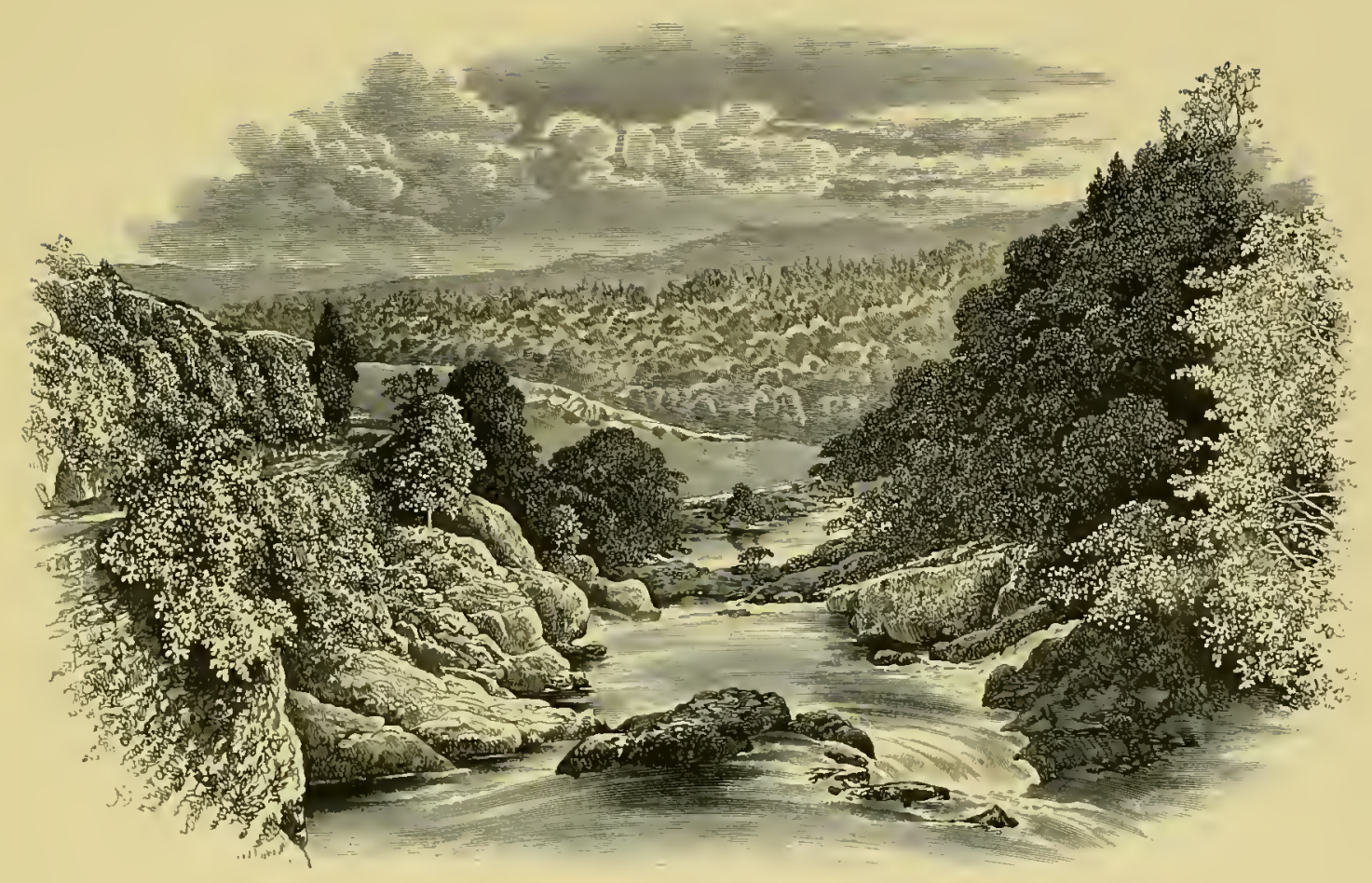

River Scene a's Pont-y-Cyffing.

Order $I V$.

PHYSOSTOMI

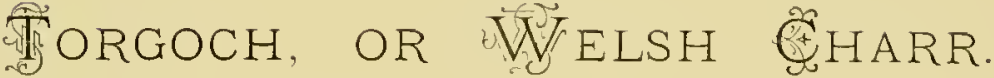

(Salmo perisii.)

Torgoch Wallis, Westmorlandis, The Red Charre lacus Winandermere,

Salmo salvclinus,

The Charr,

Salmo cambricus,

Salmo perisit,

Torgoch of Lianberris,
Family.

SALMIONID AE

Sub-generic Group-SaLvelini.

THE Welsh word Torgoch, from tor, "a belly," and coch, "red," not unaptly describes 1 this fish, which, as we have seen, has been described by IVillughby (born 1635) in his Historia Piscium. That naturalist thought that this species of Charr is identical with the Charr of Windermere; but Günther has demonstrated that the two species are distinct. Donovan, who was acquainted with this fish, says it differs from the Charr of Wynandermere, "and can be no other than the true Salmo salvclinus," a continental species, from which, however, 
it is distinct. According to Donovan, the Torgoch, at one time an inhabitant of Llanberris Lake, had disappeared entirely, on account, it was said, of the noxious waters of a neighbouring copper mine flowing into the lake and destroying the brood; in his day this Charr was confined to the waters of Llyn Quellyn, on the west side of Snowdon. "Llyn Quellyn (Cwellyn) is a vast lake of unknown depth, sheltered on one side by an abrupt mountain, which rises immediately out of the water; and in the deep recesses at the base of which the Torgoch is supposed to pass the milder seasons of the year in perfect security." Whatever may have happened about the time of Donovan, the Torgoch is now and has for some time been an inhabitant of the lake of Llanberris. Dr. Günther originally applied the specific name of cambricus to this Charr, but on his discovering that the Samo cambricus had already been used by Donovan to denote the Serven, he changed the name to perisii.

Donovan speaks with enthusiasm of the beauty of the Torgoch. It is "of an elegant and somewhat slender shape, the head long and rather pointed, and its colour splendid beyond all example among the indigenous fishes of this country. Nothing can exceed the fervid aspect of its colours when first taken; the scarlet of the belly may be truly said to emulate the glowing redness of the fiery element. The upper part of the head and back is of a deep purplish blue, blending into silvery in approaching the lateral line, beneath which the sides are tinged with yellow, passing into orange, and the orange into fine scarlet as it descends towards the belly; the whole of the back and sides are spotted in a most beautiful manner with fine red; the lower fins are also red, except the first ray of the ventral and anal which are white." Donovan's description on the whole is good, and much better than the figure he gives of this fish.

The Torgoch is a smaller species than that found in Windermere and other North of England lakes, seldom exceeding twelve or thirteen inches in length; though its size may be very probably influenced by food and water, and depends, moreover, on the constitutional vigour of the individual fish. Mr. Mascall, writing in 1835, in The Magasine of Natural History for April, says that the males of the Charr of Ennerdale Lake, in Cumberland, are superior in colour to the females. The fish from Ennerdale which I have seen and handled belong not to the Welsh Charr but to the IVindermere species; but these Ennerdale individuals appear to grow to a larger size than is attained by the same species in Windermere. If I have not made a mistake, one of these Ennerdale Charr, which I measured on the 25th. of October, I878, at Troutdale, which had been three years and a half in confinement in a tank, measured as much as twenty-two inches in length. These Charr are said to rise more freely at the fly than the same fish in Windermere. Mr. Parnaby feeds his fish on chopped pieces of horse-flesh, or other procurable food; it is likely that an abundant supply of nutritious food influences their size to a considerable extent.

The Torgoch is found in Llanberris and some other lakes of North Wales; it is not known to occur in the North of England, or in Scotland or Ireland. I give Günther's description, and mark by italics those points in which the Torgoch chiefly differs specifically from its Windermere relative:- "Body slightly compressed and elongate; the length of the head is considerably more than one half of the distance between the snout and the vertical from the origin of the dorsal. Head rather depressed; interorbital space flat, its width being less than twice the diameter of the eye; males with the lower jaw longest; teeth of moderate strength; gill-cover overlapping the root of the pectoral. Length of the pectoral less than that of the head, much more than one half of the distance between its root and that of the ventral. The nostrils are situated midway between eyeball and end of snout; the anterior is round, open, surrounded by a membrane, which posteriorly is developed into a small flap entirely covcring the smaller oblong postcrior nostril. By this character alone the Torgoch may be distinguished from the Charr (S. willughbii), and the Fresh-water Herring (S. gray'i). The back is sea green, which colour becomes lighter on the sides, assuming a yellowish shade, and 
gradually passing into the bright red of the lower parts; sides with numerous reddish orangecoloured dots. Pectoral greenish, passing into reddish posteriorly, the upper margin being white; ventral and anal red, with white anterior margin; dorsal and caudal blackish, with broad lighter margins. Cheeks and operculum with numerous black dots."

The number of the rays in the fins are

Dorsal 13

Pectoral 12.

Ventral 9.

Anal 12.

Order $I V$.

PIIYSOSTOMI.

\author{
Family \\ SALMONIDAE. \\ Sub-generic group-SALVELINI.
}

\section{消LPINE 采HARR}

(Salmo alpinus.)

Salmo alpinus,

Salmo umbla, Alpine Charr,
Lin., Faun. Suec. p. 117, No. 310 ; Syst. Nat. i. p. 510 ; Nitss., Skand. Faun. Fisk. p. 426; Günther, Proc. Zool. Soc. $186_{3}$, p. 8 ; Cat. vi. 1. 127. PARnell, Fish. Firth of Forth, Mem. Wern. Soc., vii. p. 308 . Couch, Fish. Brit. Isl. iv. p. 272 , pl. 226.

I KNOW nothing whatever of this species beyond having seen specimens in the British

1 Museum. It is an inhabitant of the Scandinavian peninsula and some waters of Scotland. The British Museum Scotch specimens are from Sutherlandshire and Invernesshire, and from Lake Helier in Hoy, Orkneys. Parnell says it is found in many of the lakes of England, Wales, and Scotland, but in all probability he is confusing this species with others. Couch has given a figure and description, as he says, "from undoubted examples of this fish, which he obtained through the kindness of Robert Embleton, Esq., from Loch Grannoch, where or in which neighbourhood alone it has hitherto been found in the United Kingdom." But this is clearly an erroneous statement. Mr. Cholmondeley Pennell mentions his having taken with a fly during a violent snowstorm in July, I862, from Loch Roy, Invernesshire, a small specimen of a very beautiful Charr, which he thought would prove to be the young of the Northern Charr. This is doubtless the specimen now in the British Museum, presented by Mr. Pennell, who thus proved himself correct in his opinion as to the species. The Scotch specimens are said by Dr. Günther to differ from those of Lapland in some respects. They are considerably smaller in size at the period of its first maturity; the largest British Museum specimen is a mature male eleven inches long; it has a more elongate body than the males from Lapland. "The operculum is as high as long; the pectoral fin terminates at a considerable distance from the vertical from the origin of the dorsal, equals the length of the 
head without snout, and is contained once and a quarter in the distance between its root and that of the ventral. The females do not differ from the males. The immature specimens have the same short pectorals which are found in the young Lap Charr, but the operculum is much less elongate." With regard to the colouration this species is said not to differ from S. willughbii; but immature specimens have the sides silvery, and the red of the lower parts is replaced by a slight tinge of orange-colour.

The fin-ray formula is stated to be

Dorsal 13 .

Pectoral 13.

Ventral 10.

Anal 9. 



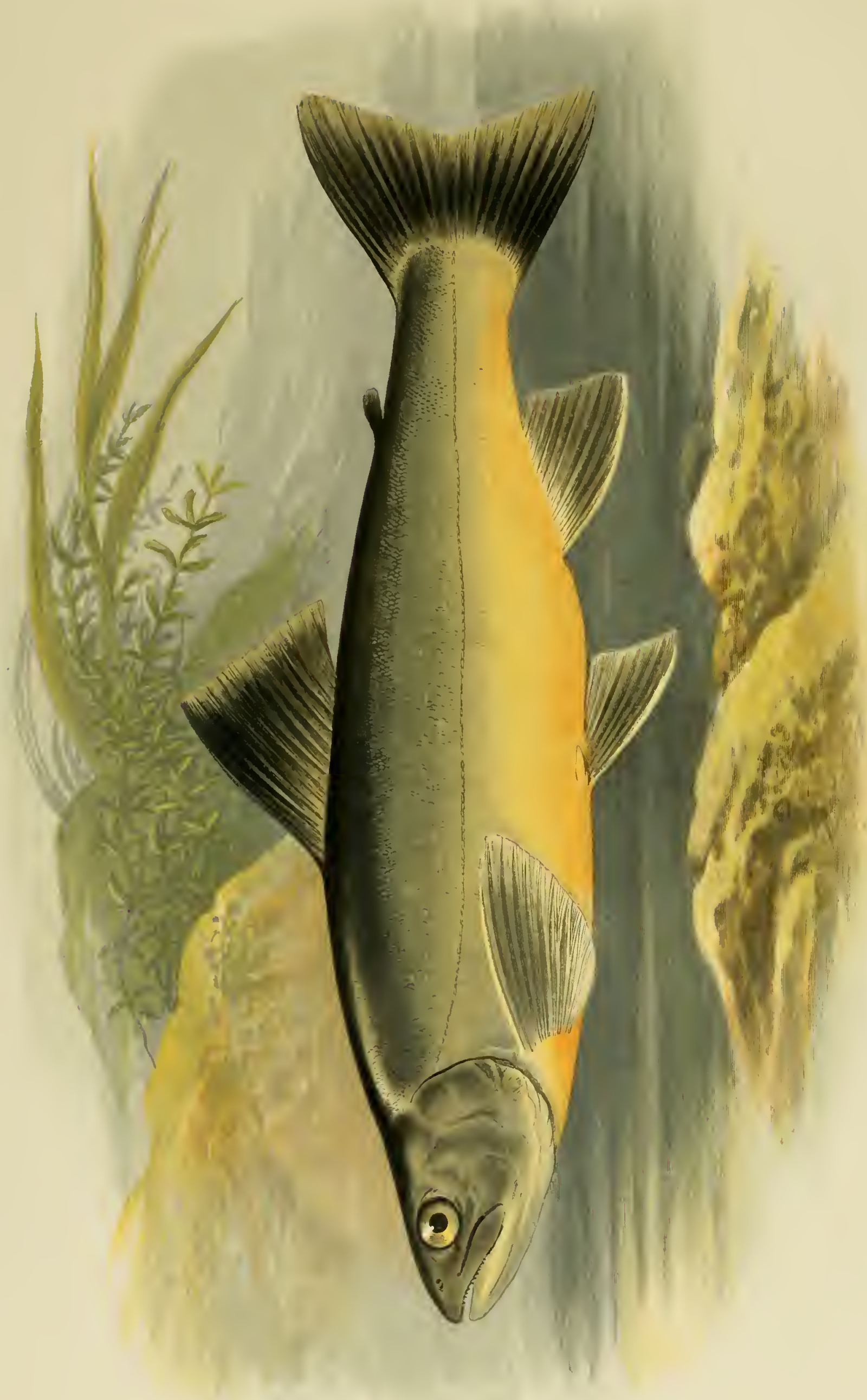

0
2
0
0
$z$
$\vdots$
$\vdots$
$\vdots$
$=$
0
0
0 


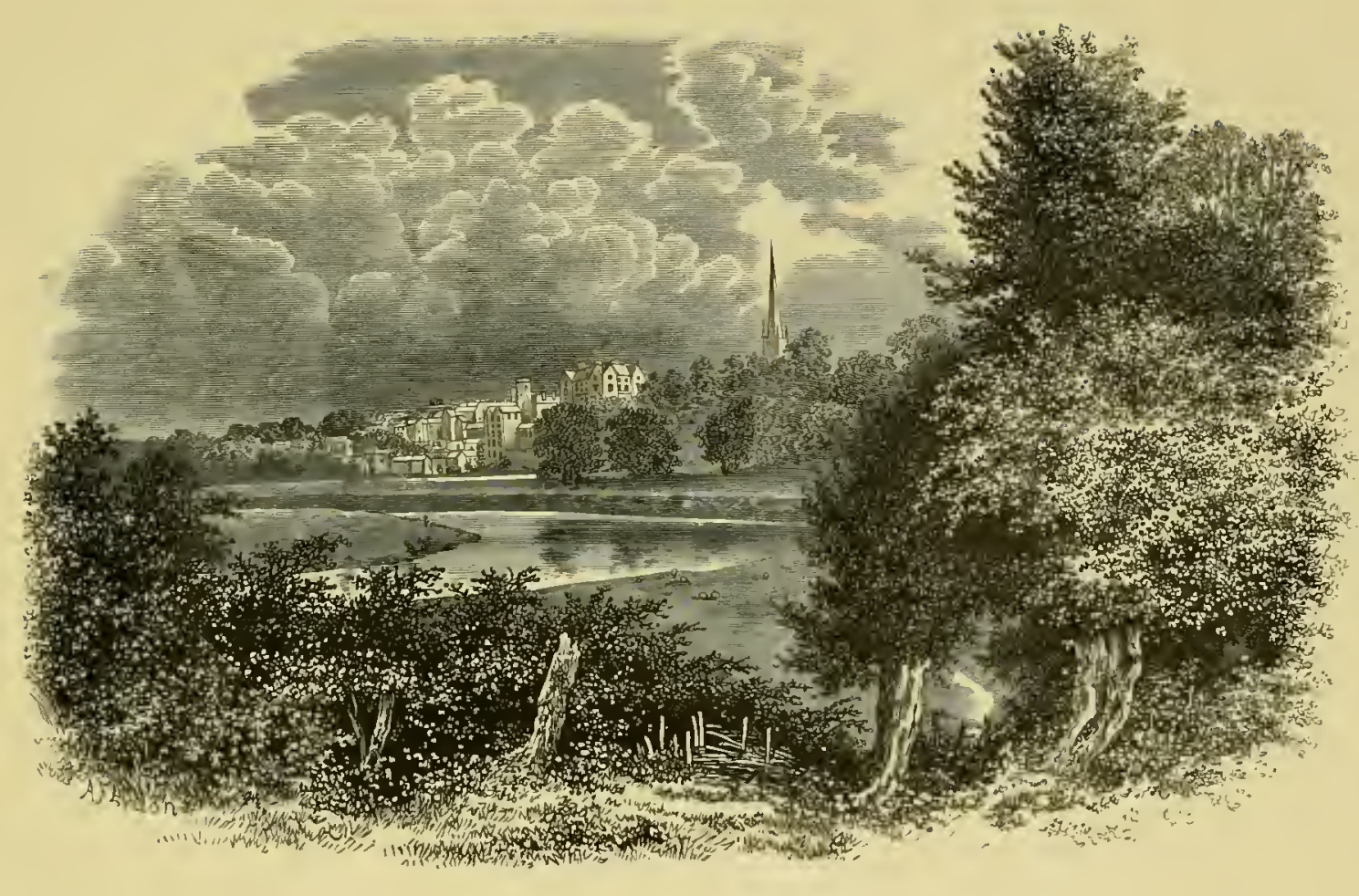

ON THE WYE,

Order $I V$.

PHYSOSTOMI
Family

SALMONIDE.

Sub-generic Group-SalveLINI.

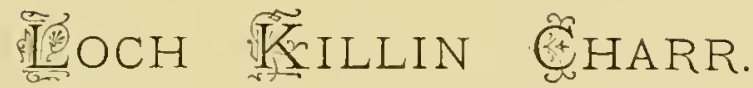

(Salmo killincnsis.)

Salmo killinensis,

GüNıHer, Proc. Zool. Soc. 1865 , p. 698, pl. ıг; Cat. vi. p. I30.

THIS is a very well characterized species of Charr, first noticed by Thompson in his work 1 on the Natural History of Ircland (iv. p. I64), and described by Dr. Günther, who has also given a good figure of this fish in the Procecdings of the Zoological Society of London, as quoted above. Thompson writes thus of this fish, "About fifteen miles from Loch Corr is Loch Killin, situated in the pastoral vale of Loch Stratherrick. Three specimens of Charr have thence been brought me. They are remarkably different from the Loch Corr example, are of a clumsy form, have very large fins like the Welsh fish, and are very dull in colour; of a blackish leaden hue throughout the greater part of the sides, the lower portion of which is of a dull yellow, no red appearing anywhere. So different indeed is this fish from the Charr of the neighbouring localities, that it is believed by the people resident about Loch Killin to be a species peculiar to their lake, and hence bears another name- 'Haddy' being strangely 
enough bestowed upon it. This fish is only taken when spawning, but then in great quantities, either with nets or a number of fish-hools tied together, with their points directed different ways. Those, unbaited, are drawn through the water where the fish are congregated in such numbers that they are brought up impaled on the hooks. The largest of my specimens is sixteen inches in length, and others of similar size were brought to my friend at the same time-on the 26 th. or 27 th. of September, when about a cart-load of them was taken. The flesh of some was white and soft. They contained ova the size of peas. On dissection my specimens were found to be male and female. Externally the sex could not have been told with certainty. Their stomach and intestines were empty. This fish bears a resemblance to the Lough Melvin Charr, but differs from it in some characters."

Dr. Günther speaks of this Charr as one of most remarkable form, which in the excessive development of its fins, differs from all the other species known to him from Great Britain and the continent of Europe. "Only Salmo grayi from Ireland, and S. nivalis from Iceland approach it in the length of the pectorals; but the former cannot well be confounded with it, having much larger scales, and the body compressed and rather elevated; from the latter it differs in several points of minor importance, and especially in the increased number of pyloric appendages, which besides are extremely narrow and slender. For specimens of this Charr I am indebted to Mr. Gould, to whom they were sent by Mr. Hanbury Barclay, and who informs me that they inhabit a very retired loch in Invernesshire, Loch Killin, about two thousand feet above the level of the sea. They are caught only in September and October, when they approach the edge of the lake to spawn."-(Proc. Zool. Soc., 1865, p. 698.)

The only specimens of this interesting Charr that I have seen are those in the British Nuseum; and through the kindness of Dr. Günther I have had an opportunity of examining them. It would be impossible to confuse this well marked fish with any other known species. Günther thus describes it:- "Head and body thick, but slightly compressed; the greatest depth of the body equals the length of the head, and is two ninths of the total length (to the extremity of the central caudal rays). The length of the head is little more than one half of the distance between the snout and the vertical from the origin of the dorsal fin. The lower jaw is rather shorter than the upper; and the maxillary extends scarcely beyond the hind margin of the orbit in adult males. Teeth very small. Snout obtuse; eye of moderate size, much shorter than the snout, and about half the width of the interorbital space. Suboperculum very short and high. Fins excessively developed; pectoral not much shorter than the head; dorsal long and high, the longest ray being nearly as long as the head (without snout), or shorter than the pectoral fin. The ventral fin extends nearly to the vent; caudal very broad, slightly emarginate. Head, upper parts and fins brownish black; lower with an orange-coloured tinge in the male; sides with very small light inconspicuous spots. Anterior margins of the lower fins white or light orange coloured." The specimens are from ten to fifteen inches long.

The fin-ray formula is

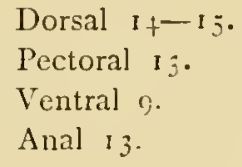

The illustration was taken from a specimen in the British Museum which was nearly fourteen inches long. 
Dr. Günther sums up the results of his investigations with respect to the British Charrs as follows. He shows that

1. Three very distinct species of Charrs are found in Great Britain, namely:-S. willughbii in the Lake of Windermere and in Loch Bruiach; S. perisii in Wales; and S. alpinus in certain parts of Scotland.

2. That those three species differ by most constant characters from the $S$. umbla and $S$. salvelinus of the Continent; but that $S$. alpinus of Scotland is closely related to the $S$. alpinus of Lapland, differing merely by its smaller size when first attaining to maturity, and by the number of vertebræ, there being sixty-two in the Scandinavian variety and fifty-nine in the Scottish.

3. That Iceland is inhabited by a distinct species (S. nivalis).

4. That the Charrs of Ireland form a separate group by themselves, distinguished by the feeble development of their dentition: and that the Charr of Lough Melvin (S. grayi) is a distinct species from that of Lough Eske and Lough Dan (S. colii).

The following synopsis of the species, showing a few of the principal characters by which the mature individuals of the different species are distinguished, will be found useful.

\section{Faw well dcveloped; tceth of moderate size.}

A. The length of the pectoral fin in the mature fish less than one half of the distance between the roots of the pectoral and ventral fins.

1. Thirteen dorsal rays. Intermaxillary teeth much stronger than those of the maxillary. L. lat. 185. Lower parts silvery. S. unzla.

2. Fourteen dorsal rays. Intermaxillary and maxillary teeth equal in strength. L. lat. 190. Lower parts red. S. salvelinus.

B. The length of the pectoral fin in the mnture fish, more than, or equal to, one half of the distance between the roots of the pectoral and ventral fins.

1. The height of the body one fifth or one sixth of the total length; the height of the clorsal fin three fifths or one half of the length of the heal. L. lat. 195-200. S. alpinus.

2. The height of the body one fifth of the total length; the height of the dorsal fin equals the length of the head, without snout. L. lat. 190. The gill-cover not overlapping the root of the pectoral. S. nivalis.

3. The height of the body one fifth or one sixth of the total length; the height of the dorsal fin two thirds of the length of the head. L. lat. 170. The gill-cover overlapping the root of the pectoral. S. perisii.

4. The height of the body one fourth of the total kength; the height of the ciorsal fin equals the length of the head, without snout. L. lat. 165. The gill-corer not overlapping the root of the pectoral. S. reillughbii.

\section{Lower jaw very fecble; tecth minutc.}

1. The pectoral extending to or beyond the origin of the dorsal fin. S. sravi.

2. The pectoral terminating at a consiclerable distance from the origin of the dorsal fin. $S$. coliz.

Of course it is possible that other and hitherto undescribed species of Charr, besides the species already known, may be found to inhabit the lakes of this country, but it is to be feared that the operation of the Salmon Acts will greatly diminish the chances of further discoveries in this line. 




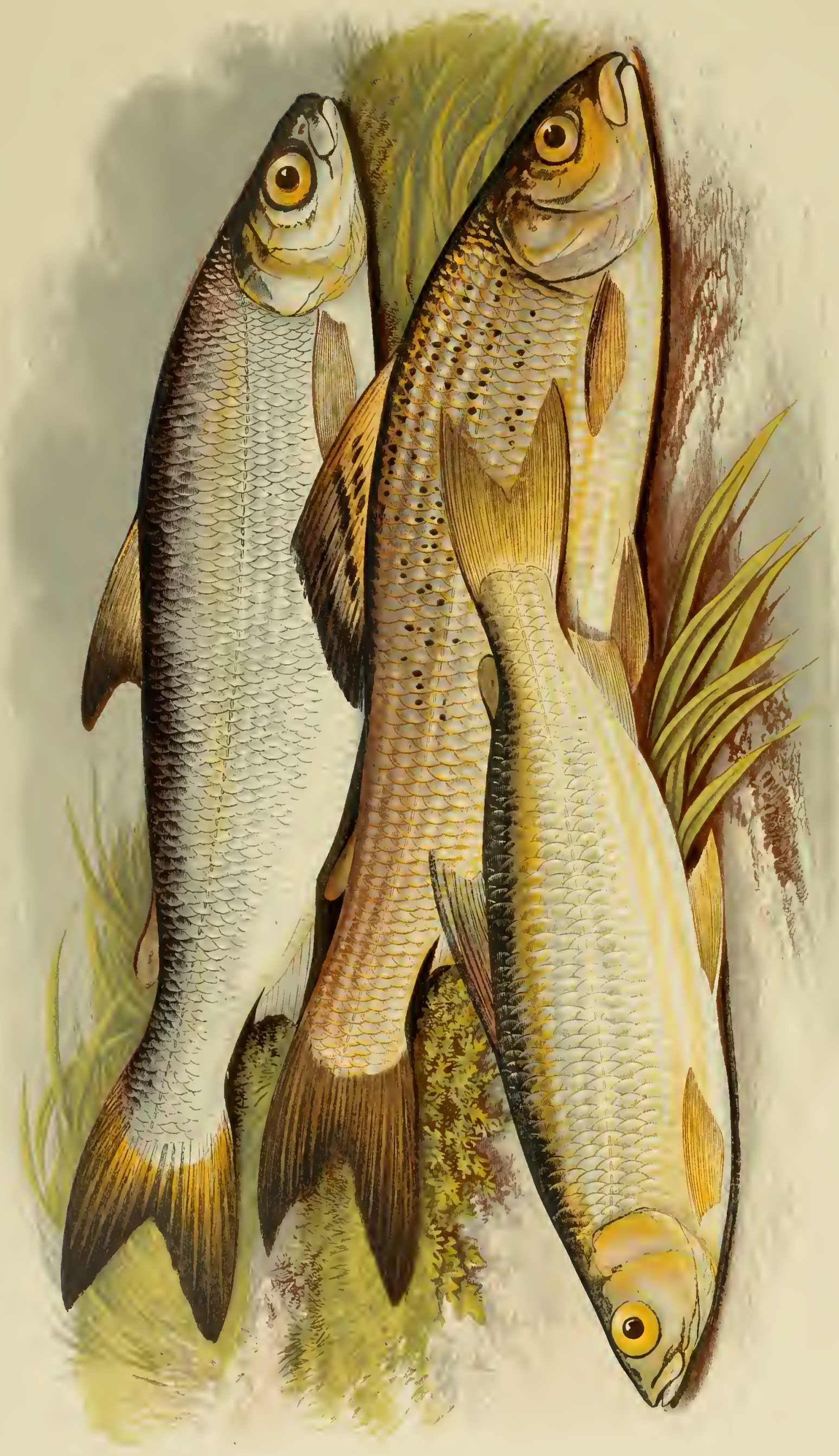




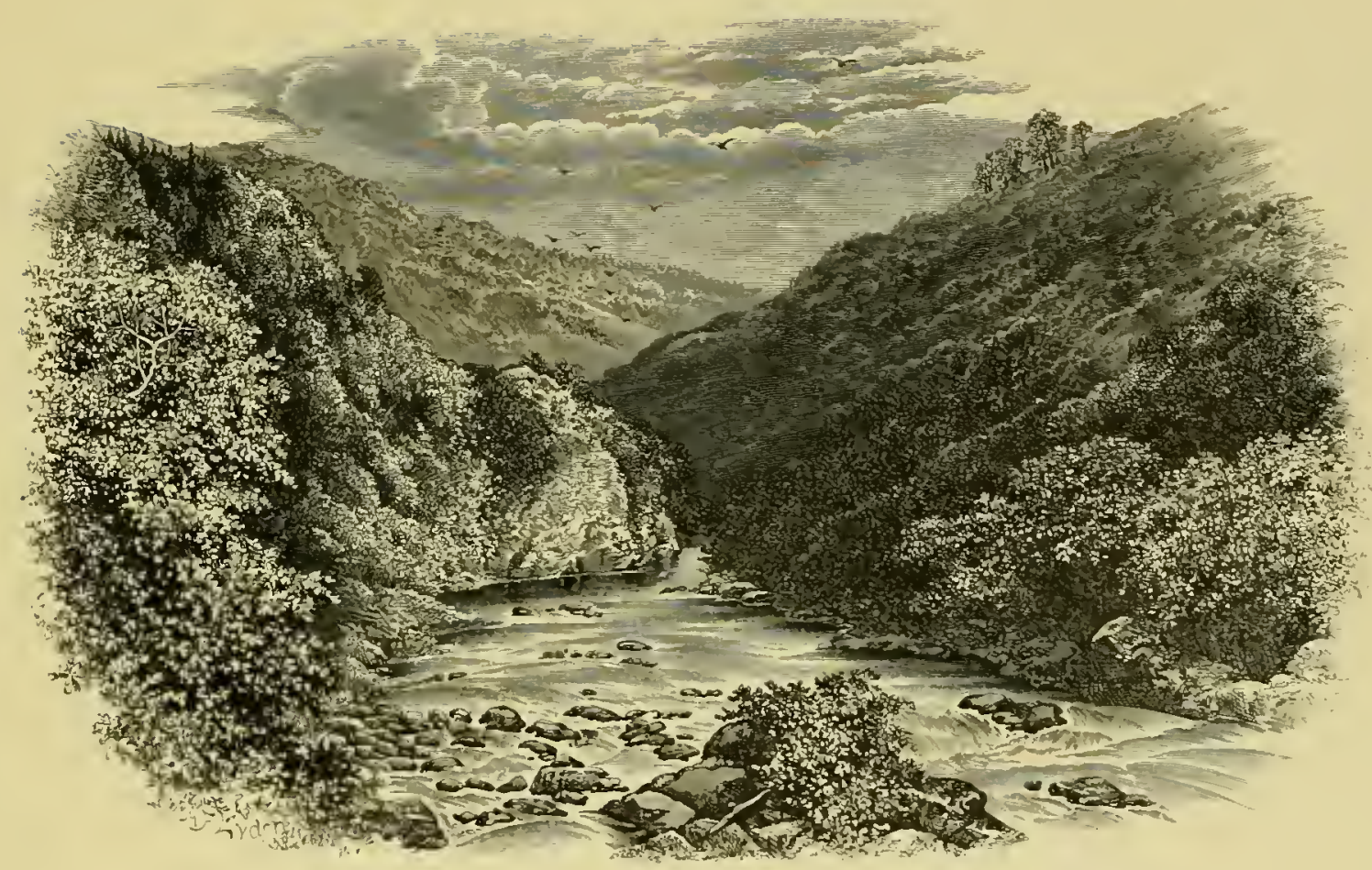

ON the part, Lover's Leap.

Order $1 \mathrm{~V}$.

PHYSOSTO.II.

\section{Thymallos,}

Thymallus seu Thy'mus,

Coregonus maxilla superiore longiore,

Salmo thymallus,

Coregonus thy'mallus,

Thymallus vulgaris,

Grayling Salmon,

Grayling or L'mber, family

SALMONID AE.

Sub-generic group-SALVELINI.

\section{GRAYLING. \\ (Thymallus vulgaris.)}

Ailian, Nat. Anim. xiv. c. 22, ed. Jacobs.

Gesner, de Aquat. p. 978; Willughby, Hist. Pisc. p. I87.

Artedi, Spec. Pisc. p. 20, No. 3 .

Lin., Sys. Nat. i. p. 512 ; Donovan, Brit. Fish. iv. pl. $8 S$.

LACÉP., v. p. 254 ; Flear., Brit. An. p. I $\$ 1$.

Yarrell, ii. p. 136 ; Jenyns, Nan. p. 430 ; Siebold, Süsserwasserf. p. 267; GÜNTHER's Cat. vi. p. 200.

Pennant, Brit. Zool. iii. p. 414 , ed. 1812.

Walton, Compl. Angl.; Sir Humphry Dary, Salmonia; Сouch, Fish. Brit. Isl. iv. p. 280, pl. 228.

Characters of the Genus THYMaldus.- "Body corered with scales of moderate size. Cleft of the mouth small: maxillary short, broad, scarcely extending beyond the front margin of the orbit. Small teeth in the jaw bones, on the head of the vomer and the palatines; none on the tongue. Dorsal fin long, many rayed; caudal forked. Pseudobranchiæ well developed; air-bladder very large. Stomach horse-shoe-shaped, pyloric appendages rather numerous. Temperate parts of the Northern Hemisphere."-GÜntHer. 
THE only classical authors who have mentioned the Grayling are Ælian, to whom this fish was known under the name of Thumallus, and Ausonius, who appears to allude to this fish in his tenth Idyll, under the name of Umbra.

“Efugiensque oculos celeri levis Umbra natatu." (90.)

Elian gives the following account of the Grayling:- "The river Ticinus, in Italy, produces the fish called Thymallus; it is about a cubit in length; in appearance it partly resembles the labrax (Sea Perch) and the cephalus (Grey Mullet). When captured it has a remarkable odour-not that other kinds are destitute of a fishy smell-so that you would say you had in your hands a freshly-gathered piece of thyme. In fact if you did not see the fish you would imagine you had the plant, which is the chief food of bees-whence the fish takes its name-in your hands, so fragrant is the smell. It is taken easily in a net, but not with a bait and hook, whether the bait be the fat of a pig, or a serphus (some two-winged fly), or a shell-fish $(X \eta \mu \eta)$, or the entrail of another fish, or the neck of a strombus. It is taken only by a small gnat, the troublesome little beast, which day and night is a nuisance to men on account of its biting and buzzing: with this, which is the only food of which it is fond, is the Thymallus captured."

The association of the odour of thyme with the Grayling, noticed by Elian, has been kept up ever since his time. It is referred to by Izaak Walton, who says, "Some think that he feeds on water-thyme, and smells of it at his first taking out of the water; and they may think so with as good reason as we do that our Smelts smell like violets at their first being caught, whịch I think is a truth." Walton also refers to the opinion of St. Ambrose- "Much more might be said of this fish's taste and smell; but I shall only tell you that St. Ambrose, the glorious Bishop of Milan, who lived when the Church kept fasting days, calls him the flower-fish, or flower of fishes, and that he was so far in love with him, that he would not let him pass without the honour of a long discourse." Willughby thinks that more modern writers are simply following in the wake of the ancients; he says Salvianus could detect no thyme flavour about the Grayling, but thinks the Grayling has a sweeter odour about it than fish in general. Pennant speaks of the "imaginary scent" like thyme, but he never could perceive any particular smell about the Grayling. Mr. Cholmondeley Pennell thinks that the odour rather resembles that of a cucumber than of thyme. Mr. Francis Francis writes, "he has a peculiar and strong fragrance when handled, which is said to be like thyme, and is so to some little extent." I must place myself among the number of persons who, as Mr. Manley says, "utterly fail to distinguish this thymy fragrance" about the Grayling; but I will not deny that to the olfactory nerves of some people, the association of the odour of this plant with the Grayling may be suficiently striking.

The Grayling is found in the fresh waters of Central and Northern Europe, but though abundant in some streams, it is a local fish, much more so than the Common Trout. As to English localities, I cannot quote a better authority than Mr. Francis Francis, who justly has a very high opinion of the Grayling. "If the Trout," he say's, "be the gentleman of the streams, the Grayling is certainly the lady." The rivers mentioned by Mr. Francis as containing these fish, are the Teme, the Lugg, and the Wye, with their tributaries wherever they are found to suit them; the Ure and the Swale, in Yorkshire. Of the Derbyshire streams, the IVye, Derwent, and the Dove. The Grayling is found in the Hampshire rivers, the Avon, Itchin, and Test, where it runs to a large size; Mr. Francis has taken Grayling, both in the Itchin and Test, up to four pounds weight. This fish has been brought into the Clyde, where it has thriven well; it is said to be increasing rapidly in the Tweed. "But there are very many other rivers-the tributaries of the Thames-where it could be naturalized; the 
two Colnes, the Windrush, parts of the Mole, the Darent, the Wey, the Brent, and others - for it is not every river which will suit the Grayling; whereas almost any river, if not already overrun with coarse fish, will suit the Trout, if there are any shallows at all for it to spawn on. Grayling love deep eddies and quiet reaches, but they also like sharp and rapid shallows-a weedy shallow which ends in a deep safe eddy, with a gravelly bottom, and loamy hollowed-out banks, being the especial abiding-place of Grayling; and where these alternate with sharp bends full of nooks and corners of refuge, the stream will suit Grayling to admiration."-(Book on Angling, p. 299-300.)

The spawning season of the Grayling is different from that of the Salmonida generally: for it occurs in April and May; so that the Grayling is in the best condition about the time when the Trout is in its worst, that is in October and November. Mr. Francis says the Grayling should not be taken till August. At spawning time, and, for long after, "the fish is scarcely eatable, and until August is not worth a rush. Cut a Grayling in June and cut one in November, and the difference is most remarkable. Although in June he may be a handsome shaped and bright-looking fish, his play is unusually dull, and his flesh like that of an indifferent roach, soft, spongy, and flavourless. In November he has a blue bloom on him like a rich plum...... his black spots contrast brilliantly with the dazzling silver of his belly; and as for his flesh, it is as hard, firm, and flaky, as a Trout's when in the best condition." Mr. Francis is amusingly angry with any angler who would take Grayling in the early summer months. "Throw him in again, then, brother fisherman, till at least the middle of July be turned. Whereas, if you do take him in May or June, listen to my solemn anathema, and let it lie heavy on your soul. May your rod-top smash at the ferrule, and the brazing stick in tight, at the commencement of your 'crack day of the season,' and may you be unable to beg, buy, borrow, or steal another rod within twenty miles. Nay you travel hundreds of miles into a strange country, find the river in splendid ply, and then discover that you have left your reel at home....... And now go and catch your Grayling in May and June, and much good may they do you. I hope you'll eat 'em,-all of them-that's all; and that your wife will have locked up the brandy, and gone out for a day or two; and please send for Dr. Francis to administer consolation. Ha! ho! I hate a fisherman who slaughters kelts and illconditioned fish, more than any other species of poacher going." - (P. 298.)

The Grayling passes its time entirely in fresh water, and I cannot understand how Donovan, whose figure, bad as it is, shows itself to be this fish, says it is migratory, "passing the winter season in the open sea, and the summer in fresh water."

The food of the Grayling consists of insects and their larvæ, small shell-fish (molluscs), crustacea, etc. In a specimen I examined I found the stomach full of the Ancychus fluviatilis. I notice that Sir Humphry Davy states that its stomach "is very thick, not unlite that of a Charr or Gillaroo Trout, and contains flies, gravel, and larvæ with their cases."-(Salmonia, p. I83, Murray, I869.) This is contrary to my experience; for in the Charr and Grayling the walls of the stomach are not abnormally thick.

The Grayling of the Teme, near Ludlow, have the reputation of being the finest in England. The scenery at Downton Castle, where Sir Humphry Davy wrote his charming Salmonia, and where the river Teme flows, is remarkably beautiful. My own associations here, however, are connected, not with the Grayling of that picturesque stream, but with the various beautiful and curious, and some rare, funguses, found in the neighbourhood. Downton is a favourite "meet" for the Woolhope Natural History Field Club, and many a pleasant day I have had with the members of it. As I have gazed into the Teme, on these fungus expeditions, in October, I have often thought how I should enjoy a day's fly-fishing, and handle the Teme Grayling, in a month in which they are in the primest condition. "Just taken out of the water," says Mr. Pennell, "the Grayling is certainly one of the most beautiful fish that can be imagined. At this time, the back is of a deep purple colour, with small 
dark irregular spots on the sides; the stomach is brilliantly white, with a fringe or lacing of gold; and the tail, pectoral, and ventral fins, are of a rich purplish tint. The dorsal fin is very large-almost disproportionally so-and is covered with scarlet spots and wavy lines, upon a dark ground of reddish brown. The little velvet back fin, near the tail, is also dark brown or purple, and the whole body is shot with violet, copper, and blue reflections, when seen in different lights. Properly to appreciate this colouring, the fish should be laid horizontally upon the hand, to be looked at, in which position its varied tinting is seen to the greatest advantage." -(Anglcr Naturalist, p. 357.)

Grayling are taken like Trout with the artificial fly, but having tender mouths they often break away, so that a light hand is very necessary, if you would be successful. Mr. Francis says that "the most slaughtering way of fishing for Grayling is with the grasshopper. The grasshopper, so called, is not a grasshopper at all, and though actually an artificial bait, in no wise resembles a grasshopper; why it should have been called a grasshopper, any more than a gooseberry, which it much more resembles, I cannot conceive. No matter: this is the grasshopper. Take a No. 5 or 6 Trout-hook; lap round the shank some lead, enough to sink it pretty quickly; over this wind Berlin wool of various colours, chiefly green, with a few turns of yellow or red, or both. The method in which this curious lure is employed at Leintwardine, which is perhaps the head-quarters of it, and where I have killed many fine Grayling with it, is as follows:- -Having saved as long into the winter as possible, a good store of gentles or maggots, you stick on the hook which protrudes from the green monstrosity, a good bunch of gentles, six or seven perhaps. Then dropping the bait into the stream to be fished, in order to see the depth, you fix, as if it was a float on the line, a bit of sliding quill. This is simply used to let you know how deep your bait is down, and when it touches the bottom; without it you could form no idea. Then coming to the pool, stream, or eddy, you cast in just clear of the heavy stream, letting the bait go to the bottom, and as soon as it touches, jerking it up and letting drop again in short jumps, and drawing it hither and thither while doing so, so as to search the entire water thoroughly, or all such parts of it as are likely to hold fish. You strike at every touch, tap, or nibble, that you may feel; and as the tackle is strong and hook big, you do not lose many fish when once fairly hooked. It is, indeed, a most destructive method, and kills all the largest and best fish; and it ought only to be tolerated when the Grayling get so far ahead as to want thinning down pretty freely, as is the case oftentimes at Leintwardine. To give some idea of the deadly nature of this bait on some streams, I have known instances where by the use of it large twenty-five or thirty pounds' baskets have been filled and emptied three times over, in one day's fishing, by a single rod. Its use is confined chiefly to the Worcester and Shropshire streams, - the tributaries of the Severn in fact."-(Book on Angling, p. 295-296.)

Unlike Trout, the Grayling never jumps out of the water, is unable to surmount obstructions or stem very rapid torrents, and is more prone to descend than to ascend the stream. Grayling rarely exceed three pounds in weight, though they are saic to have been caught weighing four or even five pounds. In this country these fish are non-migratory, being permanent residents of fresh water all the year round; but in colder latitudes, as in Scandinavia, the Grayling is found in the North Sea, Cattegat, and Baltic, according to Nilsson; in Lapland they are taken in the high fell lakes, and are said to weigh as much as eight or nine pounds. Some of the Swedish fish remain all the year in fresh water, and some are found in the Baltic at all seasons. Sir H. Davy found that in this country Grayling will not live in brackish water, but he allows that in many successive generations animals may be fitted to bear changes which would have destroyed their progenitors. The northern species, the Salmo thymallus of Linnæus and Bloch, the Thymallus vulgaris of Nilsson, appears to be identical with our British species.

Grayling are said to grow rapidly, and to attain to the size of four or five inches in a 
few months' time. Sir Humphry Davy (Salmonia, p. 188) goes so far as to believe that Grayling hatched in May and June become in September or October of the same year nine or ten inches long, and to weigh from five ounces to half a pound. This I feel sure is a mistake. Such fish would surely be quite a year old. Grayling ova as well as fry may, I believe, be had from Mr. Parnaby, of Troutdale Fishery, Keswick, in the season.

The fin-ray formula in the Grayling is

$$
\begin{aligned}
& \text { Dorsal } 20-23 . \\
& \text { Pectoral } 10 . \\
& \text { Ventral } 10-11 . \\
& \text { Anal } 13-10 .
\end{aligned}
$$

The specimen which supplied the illustration was caught by myself with a fly in the Severn; it is a male fish.

\section{Order $I T$.}

PHISOSTOMII.
Family

S.A LMONIDAE

Sub-generic Group-Salvelins.

\title{
GWYNIAD.
}

\author{
(Corcgonus clupcoides.)
}

\author{
Guiniad Mallis, piscis lucus Bulusis, \\ Gicyniad Salmon, \\ Coregonus clupeoides, \\ Coregonus lacepedii. \\ Coregonus laziartus, \\ Groyniad, Schelly' (Ullsziater), \\ Guiniad,
}

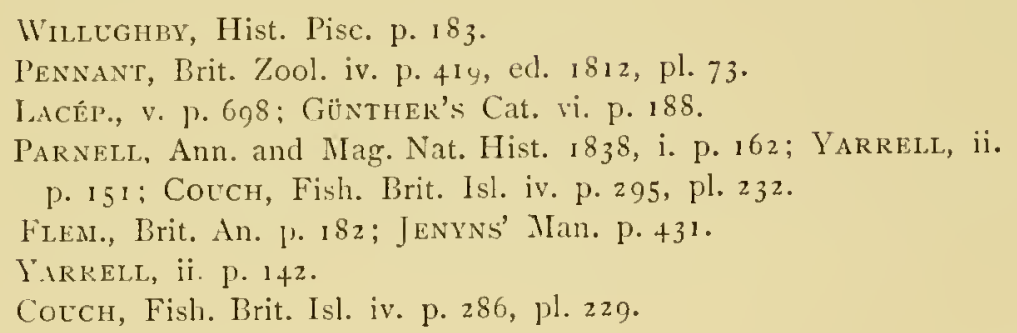

Characters of the Genus Coregonus.-"Body covered with scales of moderate size. Cleft of the mouth small; maxillary broad, short or of moderate length, not extending behind the orbit. Teeth, if present, extremely minute, and deciduous. Dorsal fin of moderate length: caudal deeply forked. Psendobranchiæ well developed; air-bladder very large. Stomach horse-shoe-shạıed; pyloric appendages extremely numerous. Ora small."-GünTHER.

$\mathrm{T}^{\mathrm{T}}$ HE fishes belonging to the genus Corgonus are inhabitants of the northern parts of temperate Europe, Asia, and North America. The three British species are found only in lakes, but there are many foreign kinds which periodically ascend from the sea, especially from the Arctic Ocean.

According to Dr. Günther the species of this genus are not less numerous than those of Salmo, some having a very extended geographical range, whilst others are confined to very limited localities. They are less subject to variation than the Trout, and therefore more easily characterized and distinguished. "Hence we find that naturalists who look with distrust on the different species of Salmo are quite ready to admit those of Coregonus. The characters 
which are the most reliable are the shape of the snout, the development of the maxillary, the form of the supplemental bone of the maxillary, the length of the mandible, the height of the body and tail, the position of the dorsal, and the number of scales and vertebra."

The Gwyniad, which in Welsh denotes "making white," "a white fish," from grvyn, "white," is a good name for this bright silvery fish. It is mentioned by Willughby, who seems to have thought that it is identical with S. fera (Cuvier and Valenc.) of the great lakes of Switzerland, the Tyrol, etc., a larger species than any of our British species. Villughby noticed the great number of cæcal appendages in the Gwyniad, its gregarious habits, and its whiteness. As to locality he says, "Invenitur in lacu Pimblemeer dicto, proprie oppidum Bala, in comitatu Merionethensi Wallice, non autem in fluvio Dea qui eum perfluit." -(P. I 84.) He is correct in identifying this fish with the Schelly of Cumberland, "qui in lacu Hulswater non procul ab oppido Percth (Penrith) invenitur." Willughby mentions its similarity in form to a Herring, which is also true of the Irish species, the Pollan.

I owe much to the kindness of Sir Watkin Williams Wynn, Bart., who, with his wellknown willingness to be of service, placed his pretty little steam-launch (which, by the way, bears the name of "Gwyniad,") at my disposal on the 28th. of September, i878, for the express purpose of procuring me specimens of this Bala fish. I also have to thank Mr. Owen Wynne and Mr. Bigge for their kindness in accompanying me, and for the enjoyment of a very pleasant day with the nets on that beautiful lake. It is true that we succeeded in capturing only one Gwyniad, though we worked for a great part of the day;* nevertheless, it was an interesting sight to behold this brilliantly shining specimen, iridescent with the most delicate colours, as it lay on the grass just after it was taken out of the water. As these fish swim in shoals, there is often great uncertainty as to their falling within the parts of the lake swept by the net.

This fish, under the name of Schclly (from the scales), occurs, as has been said, in Ullswater, and in Haweswater. In Scotland it is found in Loch Lomond, where it is called a Powen. I believe the Gwyniad is still numerous in Ullswater. Pennant writes that he was informed, that during one day in the summer as many as seven or eight thousand were caught at one draught of the net. The Grvyniad is a delicate fish, and dies soon after it is taken out of the water. The flesh is said to be rather dry and insipid; but the poorer classes, who consider them as Fresh-water Herrings, preserve them with salt, and thus use them as food; indeed they are very bad-keeping fish, like the salt-water Herring, properly so called. The spawning time is towards the end of the year; the ordinary size is from ten to twelve inches in length. Little is known with respect to the habits of this fish; I believe it is not known what places they select for spawning, nor is there any publisheci account of that proceeding. They do not run up the rivers out of the lakes for this purpose, but probably approach the shores, but whether the ova are deposited in the gravel or on water-weeds I do not know. Bala Lake is or was known by the names of Pemble-Mere, and the IVelsh Llyn Tegid, meaning "fair lake,"-and rightly is it so called. "It has long ago been observed in Camden," says Pennant, (Brit. Zool. iv. p. 421, ed. 1812,) "that these fish (Gwyniad) never wander into the Dee, or the Salmon ever ventures into the Lake; this must be allowed to be generally the case, but by accident the first have been known to stray as far as Llandrillo, six miles down the river, and a Salmon has now and then been found trespassing in the Lake." $\dagger$

The specimen I procured from Bala is small, being six inches and a half in length, without the tail; depth of body one inch and five eighths; length of the head one inch and three eighths; snout truncated; upper jaw slightly longer than lower; the maxillary is broad

* We secured, however, some Pike in glorious condition, quite pictures to behold.

† That Salmon sometimes enter Bala Lake from the Dee is certain. On my visit on the 28 th. of September, one splendid female Salmon in spawning colours was taken out of the lake. 
and flat to about the anterior margin of the eye; pectoral pointed, its length is more than half the distance between its base and that of the ventral fin. The colour above lateral line a beautiful glossy brown, slightly tinged with delicate pink; iridescent and silvery below lateral line; belly pure white; gill-cover bright silvery; eye large, irides white; tail deeply incised.

The fin-ray formula in this species-

Dorsal $14-15$.

Anal 3 3 6 . 6 .

Order $I V$.

PHYSOSTOMI.

\author{
Family \\ SALMIONIDAE. \\ Sub-generic Group-SaLvelini.
}

\section{VENDACE.}

(Corcgonus vandesius.)

\author{
Vandesus et Gevandesius, \\ Vangis and Juvangis of Loch Maben, \\ Vendace, \\ Coregonus marcenula: \\ Coregonus woillughili, \\ Coregonus vandesius,
}

Sibrald, Scotia Illustrata p. 26.

Pennant, Brit. Zool. iii. p. 420 , ed. i 812.

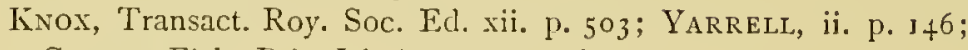
Covch, Fish. Brit. Isl. iv. p. 289 , pl. 230.

Jenyns' Man. p. 432 .

Jardine's Illust. Scot. Salm. pl. 6; TARrell, ii. p. 146.

Richardson, Faun. Bor-Amer. iii. p. 2 I3; Günther's Cat. vi. p. 194.

$\mathrm{T}$

HE only recorded locality for the Vendace is, I believe, Loch Maben, in Dumfriesshire, and the neighbouring waters. Sir William Jardine was the first to recognise this fish as a distinct species. His account of it I shall transcribe, as I know nothing of this fish excepting from specimens in the British Museum and in that at Liverpool. "The Vendace is well known to almost every person in the neighbourhood; and if among the lower classes fish should at any time form the subject of conversation, the Vendace is immediately mentioned, and the loch regarded with pride, as possessing something of great curiosity to visitors, and which is thought not to exist elsewhere. The story that it was introduced into these lochs by the unfortunate Mary Queen of Scots, as mentioned by Pennant in his description of the Gwyniad, and it is likely that his information was derived from this vicinity, is still in circulation. That the fish was introduced from some continental lake, I have little doubt;* but would rather attribute the circumstance to some of the religious establishments, which at one time prevailed in the neighbourhood, and which were well known to pay considerable attention both to the table and the cellar. Nary would scarcely prefer a lake so far from even her temporary residence, for the preservation of a luxury of troublesome introduction, and leave her other fishponds destitute of such a delicacy. An idea prevails that this fish, if once taken from the water, will die, and that an immediate return will be of no avail; and it is also believed that it will not exist in any other water except that of the Castle Loch. These are, of course, opinions which have gradually, from different circumstances, gained weight, and have at last there.

* This species is not, I believe, known to occur anywhere on the Continent; but one cannot say it does not exist 
been received as facts. The fish is of extreme delicacy: a circumstance which may have given rise to the first notion; and the introduction of it must have taken place by means of the spawn, the fish themselves, I am confident, could not be transported alive even a few miles. As to the second opinion, they are not confined to the Castle Loch, but are found in several others, some of which have no communication with that where they are thought to be peculiar.

In general habits the Vendace nearly resemble the Gwyniad, and indeed most of the allied species of the genus. They swim in large shoals; and during warm and clear weather retire to the depth of the lakes, apparently sensible of the increased temperature. They are only taken with nets, a proper bait not being yet discovered; and the fact that little excrement is found in their intestines has given rise to another tradition, that they are able to subsist without food. They are most successfully taken during a dull day and sharp breeze, approaching near to the edges of the loch, and swimming in a direction contrary to the wind. They spawn about the commencement of November, and at this time congregate in large shoals, frequently rising to the surface of the water, in the manner of the Common Herring, and making a similar noise by their rise and fall to and from the surface. The sound may be distinctly heard, and the direction of the shoal perceived, during a calm and clear evening. They are very productive. The lochs abound with Pike, of which they are a favourite food; but their quantity seems in no degree to be diminished, notwithstanding that immense numbers must be destroyed. They are considered a great delicacy, resembling the Smelt a good deal in flavour; and though certainly very palatable, the relish may be somewhat heightened by the difficulty of always procuring a supply. During the summer fishing parties are frequent, introducing some stranger friend to the Loch Maben Whitebait; and a club, consisting of between twenty and thirty of the neighbouring gentry, possessing a private net, etc., meet annually in July to enjoy the sport of fishing and feasting upon this luxury." Mr. Yarrell tells us that in the autumn of 1840 , when he was staying with Sir William Jardine, he saw some Vendace caught, and partook of some at dinner. He considered "the fish quite entitled to all their character for excellence."

The principal food of the Vendace appears to be the minute crustacea, as the Entomostraca, "for feeding on which," Sir William Jardine says, "the structure of the mouth is beautifully adapted." According to Dr. Knox, the females of the Vendace are more numerous as well as larger than the males, often measuring more than eight inches in length, the males being seldom more than seven inches.

To judge from the figure (pl. vi.) which Sir William Jardine has given, the Vendace, when fresh out of the water, must be a most beautiful fish. The specimen he has figured is thus coloured:- The back is olive, a little. darker towards the shoulders; dorsal fin olive with pink tinge at the base; adipose fin olive, caudal lighter olive, brownish at base, and much forked. Near the lateral line are some pinkish specks; below lateral line the body is slightly yellowish for a short depth, then white iridescent violet reflections; gill-covers violet and pink; upper part of the pectoral fin tinged with yellow. Anal white, with violet tinge at the base; gill-cover with a violet patch gradually fading away. This species is said to be but little variable in colour. In the Vendace the under jaw is the longest; mouth small; maxillary short, but broad and flat, reaching half way to the eye, and bent. Scales of moderate size, easily detached; the eye is large and prominent.

The fin-ray formula is stated by Dr. Günther to be

Dorsal 11 .

Anal 13 .

Ventral i1.

I do not know whether the young of the genus Corrgonus are barred like those of the genera Salmo and Thymallus. 



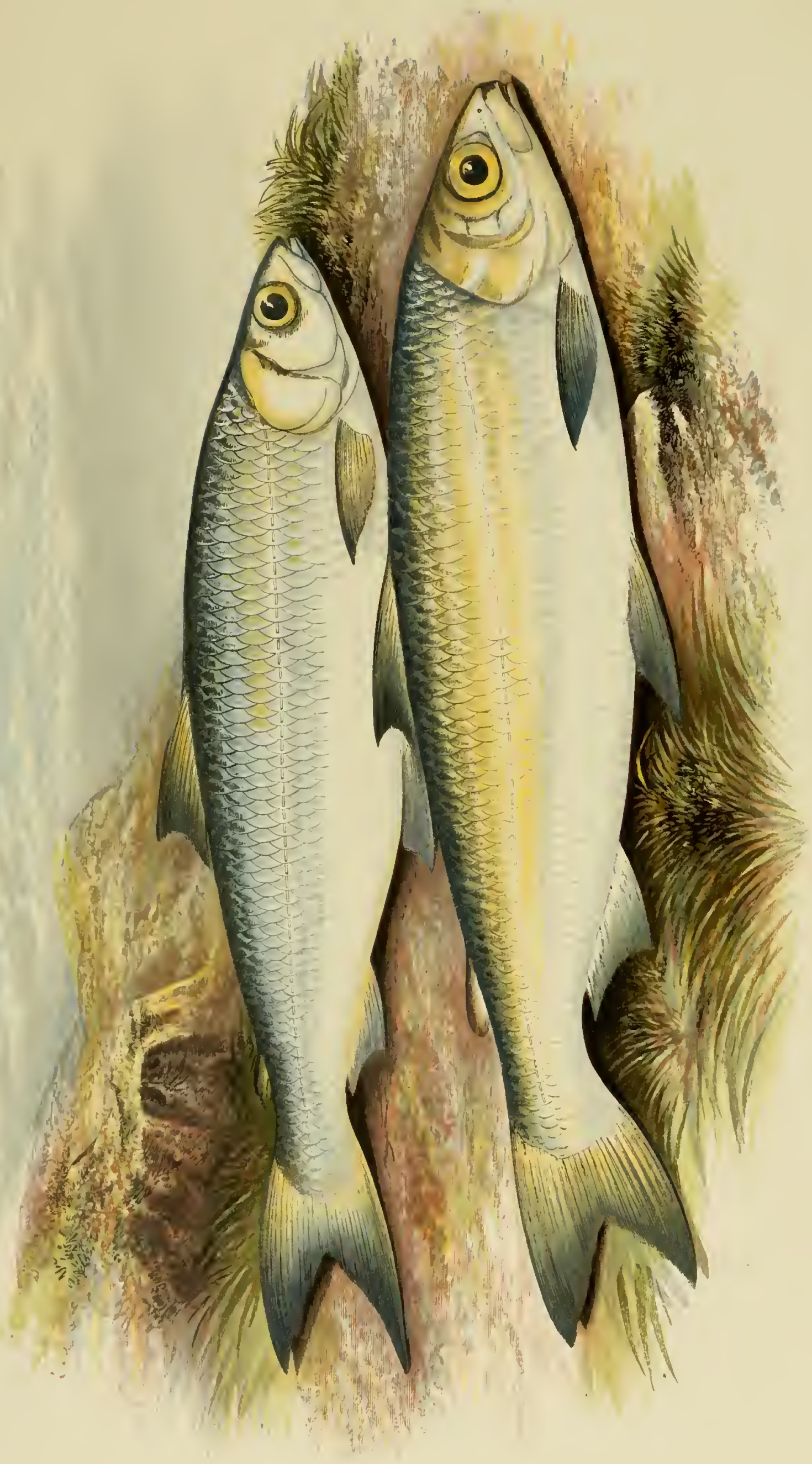





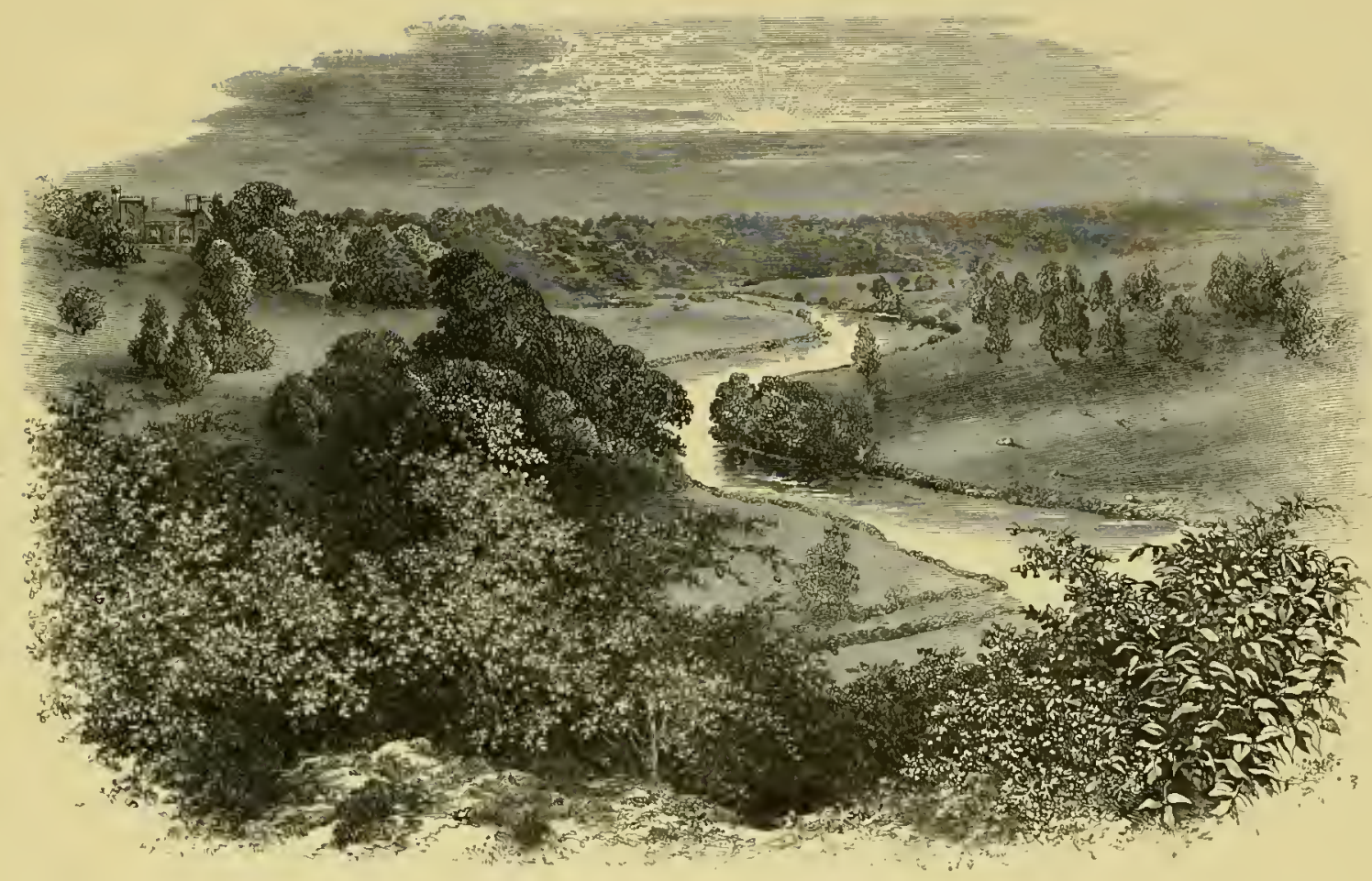

THE Wye, From GoOdrich Castle.

Order $I V$.

PHISOSTOMI.
Family

SALMONIDE.

Sub-generic Group-Satvelini.

\section{埅OLLAN.}

(Corcgonus pollan.)

Coregonus pollan,

Thompson, Proc. Zool. Soc. for 1835, 1) 77; Nat. Hist. of Ireland iv. p. 168; Jenyns' IIan. p. 432; Yarrell, ii. p. 156; Colch, Fish. I3rit. Isl. iv. p. 292. 1.l. 23 I; Günther's Cat. vi. p. 194.

F the three British species of Corconuls, the Pollan of Ireland is the only one that may be said to have any commercial value. This species was first described by Thompson in the Procecdings of the Zoological Socicty, 1835, and the description reprinted in his Natural History of Ircland. "The earliest notice of this species," writes Mr. Thompson, "that I have seen is in Harris' History of the County of Down, published in the year 1744, as well as in the statistical surveys of the counties of Armagh and Antrim; it has subsequently been introduced as one of the fishes of Lough Neagh, under the name of Pollan; but as may be expected in works of this nature, little more than its mere existence is mentioned." Large quantities of Pollan are caught during the season by the fishermen in the vicinity of Lough Neagh, but they are not taken in such numbers as formerly, owing, it was told me when at Toome 
Bridge, to the enormous destruction of the fry of these fish, which a few years ago were caught in nets of small mesh. This, I believe, has been very properly stopped. The fishermen catch the Pollan in different parts of the great Irish lake, and pack them in boxes; they are then brought to Toome Bridge, and conveyed by rail to the coast, whence they find their way to Liverpool, Manchester, and other towns. Thompson mentions the greatest take of these fish he ever remembers as having occurred in September, 1834: it was at the bar mouth, where the river Six-mile Water enters the lake. "At either'three or four draughts of the net one hundred and forty hundred (one hundred and twenty-three individuals to the hundred) or seventeen thousand two hundred and twenty fish were taken; at one draught more were captured than the boat could with safety hold, and they had consequently to be emptied on the neighbouring pier. They altogether filled five one-horse carts, and were sold at the spot at the rate of 3s. 4d. a hundred, producing $£ 236 \mathrm{~s}$. $8 \mathrm{~d}$. They are brought in quantities to Belfast, and when the supply is good the cry of "fresh Pollan" prevails even to a greater extent than that of "fresh Herring," though both fishes are in season at the same period of the year."

The Pollan is said to deposit its spawn where the lake presents a hard rocky bottom; this occurs in December. The stomachs of those fish I examined last July contained the remains of the larvæ of insects and some small crustacea. Those which Mr. Thompson examined in June, 1836 , were full of the larvæ of various aquatic insects, but chiefly of mature individuals of Gammarus aquaticus (fresh-water shrimp); some shells of the genus Pisidium, and one of the fry of the Three-spined Stickleback also were found. Besides inhabiting Lough Neagh, the Pollan occurs in Lough Derg, an expansion of the Shannon. Yarrell was supplied with a jar full of Pollan from Lough Erne, in County Fermanagh, by the Earl of Enniskillen; those specimens are said to be deeper in proportion to the length than those from Lough Neagh.

The following is a description of a female specimen I examined on July I Ith., I878:Total length ten inches and a half; depth two inches and five eighths; length of head two inches; the maxillary, reaching to the middle of the eye, rather broad, but thin and short; præoperculum with distinct lower limb; snout short and obtuse; lateral line distinct, beginning from above the gill-cover, descending for about six scales, then going in a straight line to the middle of the caudal fin, which is deeply incised. Dorsal fin light, tinged with smoke colour, as also the tail; the anal, ventral, and pectoral fins white and immaculate. Colour of head and back bluish brown, the rest of the body bright silvery; pyloric cæca very numerous, densely crowded, covered with fat; the ovaries consisted of two lobes, four inches and five eighths long, of bright orange colour; and the contained ova were about the size of dust-shot. Air-bladder very large; teeth none, or extremely rudimentary. The whole fish was thick and fat, though the intestines were full of tania.

The people at Toome and in the neighbourhood ascribe a soporific property to the flesh of the Pollan. "You must move about, Sir," a boatman said to me, "soon after eating them, or they may send you to sleep." Lieutenant-Colonel Masefield and myself had a dish of Pollan fried, and we thought them very fair food; we both thought they resembled in flavour and texture of flesh very good Dace. Neither of us felt inclined to go to sleep after eating them, but then the Colonel is more wide awake than most men.

The size of full-grown adult specimens is about ten to twelve inches long, and I do not think they often attain to a greater length.

The fin-ray formula of the Pollan is

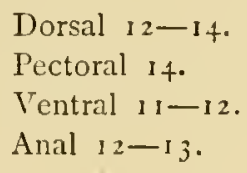

The specimen figured was taken in a net at Lough Neagh. 


\section{POWNAN.}

TWHE fish of Loch Lomond which, under the name of Powen, or Powan, has been thought

1 by some to be a species of Coregonus distinct from $C$. clupeoides, or the Givyniad, appears to be identical with it. Parnell, considering it to be a distinct species, named it after the French naturalist, Lacépède, and this is retained by Yarrell in his second edition. "These fish," says. Parnell, "are found in Loch Lomond in great numbers. They are caught from the month of March until September with large drag nets, and occasional instances have occurred in which a few have been taken with a small artificial fly; a minnow or bait they have never been known to touch. Early in the morning and late in the evening large shoals of them are observed approaching the shore in search of food, and rippling the surface of the water with their fins as they proceed. In this respect they resemble in their habits the Vendace of Loch Maben and the salt-water Herring. They are never seen under any circumstances in the middle of the day. From the estimation these fish are held in by the neighbouring inhabitants, they are seldom sent far before they meet with a ready sale, and are entirely unknown in the markets of Glasgow. In the months of August and September they are in the best condition for the table, when they are considered well-flavoured, wholesome, and delicate food. They shed their spawn in October to December, and remain out of condition till March."

There seems to be no doubt that the Powan is merely the Scotch representative of the Welsh Gwyniad. The Coregonus microcephalus of Parnell is also to be referred to the Gwyniad.

The food of the Gwyniad, and of the other British species of Corcronus, consists principally of insect larva, both those which swim in the water, as the Ephemerida, and those which are attached to stones, as some of the Trichoptera. 



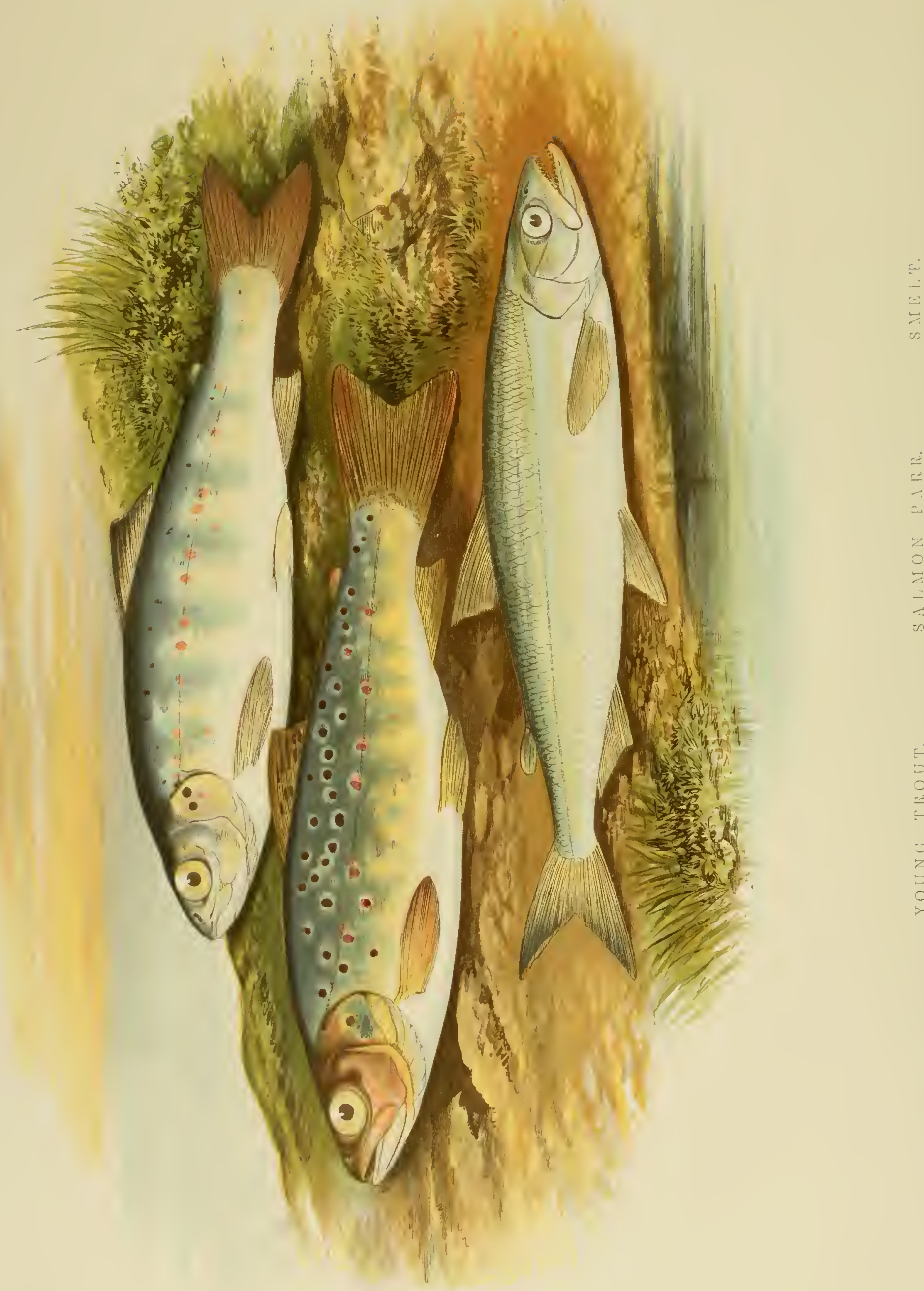


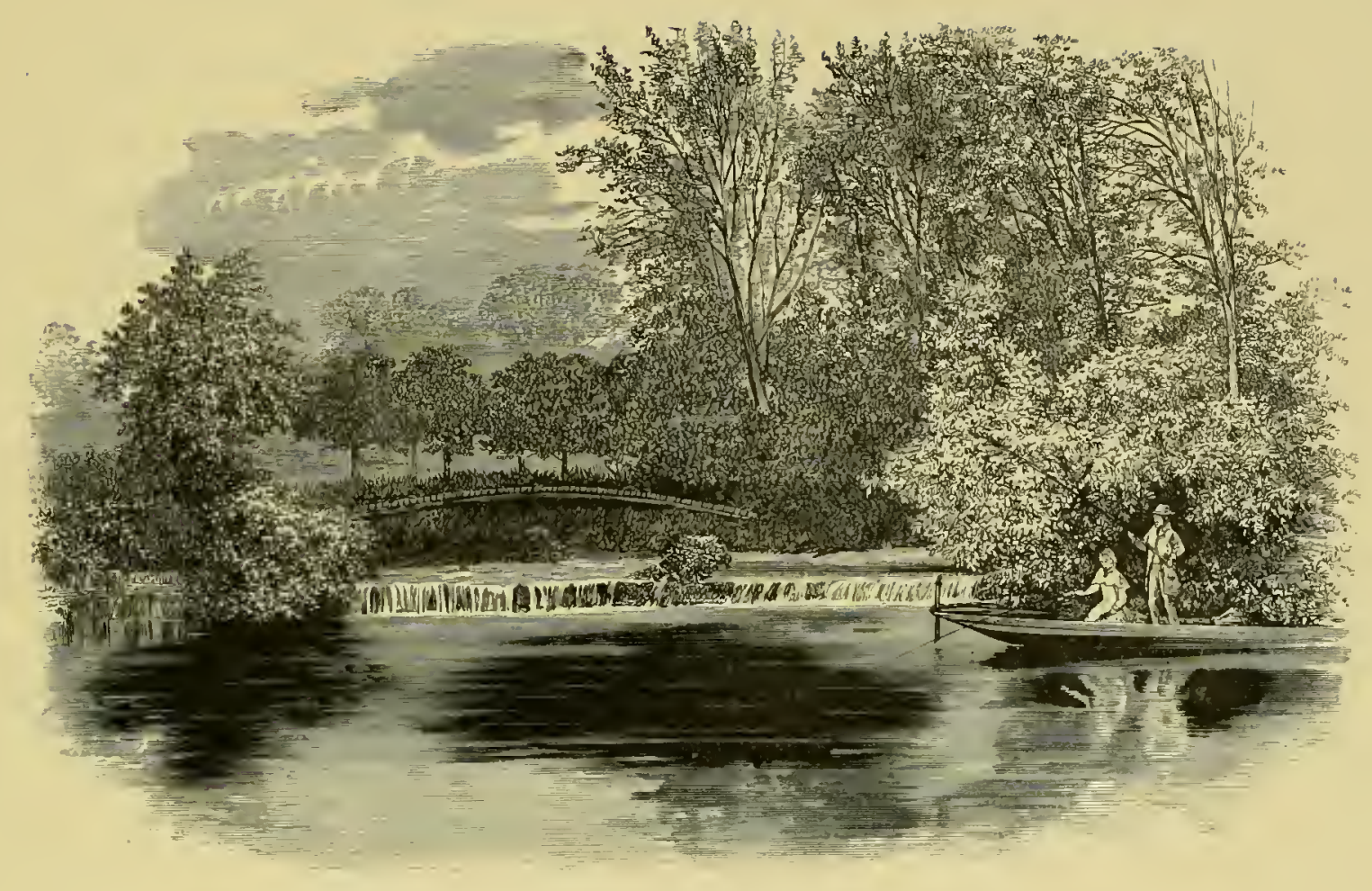

At Cleeve, on the Thames.

Order $I V$.

PHYSOSTOMI
Family

SALMONIDA.

Sub-generic group-SaLvelivi.

\section{SMELT, SPARLING.}

\section{(Osminus cperlanus.)}

\author{
Eperlanus, \\ Osmerus, \\ Salmo eperlanus, \\ Smelt Salmon, \\ Smelt, Spirling and Sparting, (Sintland), \\ Osmerus epirlanus,
}

Epirlanus anlgaris,
Wiliughby, Hist. Pisc. p. 202.

Artedi, Syn. Nom. Pisc. p. +5 ; Spec. Pisc. p. 21 , No. 1.

Lin., Sys. Nat. i. p. 51 ; Donovan, Brit. Fish. ii. pl. +8 .

Pennant, Brit. Zool. iii. p. +16 , ed. 18 Iz.

YARRell, ii. p. 129; Couch, Fish. Brit. Isl. iv. p. 276, pl. 227 .

LACÉP., v. p. 229 ; FleMr., Brit. Anim. p. 181 ; JenYns' Man. p. 429.

Parneli, Fish. Firth of Forth, Mem. Wern. Nat. Hist. Soc. vii. p. 312 ; Yarreld, ii. p. 129; Siebold, Süsserwasserf. p. 271 ; GǗnther's

Cat. vi. p. 166

Gaimard, Voy. Isl. et Grœnl. pl. 18, fig. 2.

Characters of the Gemes Osmekus.- "Body covered with scales of moderate size. Cleft of the mouth wide; maxillary long, extending to, or nearly to, the hind margin of the orbit. Dentition strong; intermaxillary and maxillary teeth small, much smaller than those of the mandible. Vomer with a transverse series of teeth, several of which are large, fang-like; a series of conical teeth along the pralatine and pterygoid bones. Tongue with very strong fang-like teeth 
anteriorly, and with several longitudinal series of smaller ones posteriorly. Pectoral fins moderately developed. Pseudobranchix present, but rudimentary. Blind sac of the stomach of moderate length. Pyloric appendages very short, in small number; ova small. Atlantic coasts of the temperate parts of Europe and North America; periodically ascending rivers, and frequently permanent residents of fresh waters."-GüNTHER.

TTHE Smelt or Sparling is, perhaps, one of the most delicate in flavour of all fish that swim, whether in salt or fresh water. It is one of the few fishes which possess any strong peculiar and decided flavour. Willughby's opinion is expressed in these words,- "Carne est molle et friabile, sapore delicato, gratissimum violæ odorem spirante."

The Smelt is an inhabitant of fresh water from August to May. They spawn in March and April, and about this time descend to the sea. Pennant, speaking of the peculiar odour, - which some compare to the cucumber, others to violets,-says, "They have a very particular scent, from whence is derived one of their English names, Smelt, i.e. smell it. That of Sparling, which is used in Wales and the north of England, is taken from the French Eperlan. There is a wonderful disagreement in the opinion of people in respect to the scent of this fish; some assert it flavours of the violet; the Germans, for a very different reason, distinguish it by the elegant title of Stinkfisch." "The derivation of the word Smelt is referred by Johnston to the smelting of metals, in allusion to the transparency and delicacy of this fish; this is obviously wrong, for the name of the genus Osmerus, as first used by Artedi, has

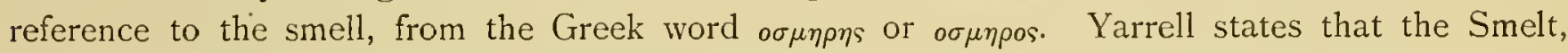
as a British fish, appears to be almost exclusively confined to the eastern and western coasts of Great Britain. The Smelt is abundant in Scotland, not so common in Ireland, where it is local; Couch says that no Smelts have been recognised along the shores of England from the Thames westward to the Land's End. They formerly abounded in the Thames, from Wandsworth to Putney Bridge, and from thence to the Suspension Bridge at Hammersmith from thirty to forty fishing-boats might have been seen working together many years ago. Below Woolwich, where it is said they now alone appear in the Thames, the angler would scarcely be inclined to go and try his luck among Smelt.

Though the Smelt is a pearly and fragile-looking fish, it appears to be voracious in its habits. A writer in Land and Watcr found shrimps and small fish in quantities in their stomachs.

Dr. Günther states that Smelts are frequently permanent residents of fresh waters. Experiments have been occasionally made in this country to retain it in ponds, one of which, as recorded by Yarrell, was attended with complete success. "Colonel Meynell, of Yarm, in Yorkshire, kept Smelts for four years in a fresh-water pond, having no communication with the sea: they continued to thrive, and propagated abundantly. They were not affected by freezing, as the whole pond, which covered about three acres, was so frozen as to admit of skating. When the pond was drawn, the fishermen of the Tees considered that they had never seen a finer lot of Smelts. There was no loss of flavour or quality."--(ii. p. 131). I do not know what further experiments have been made in this way, but I have often thought that modern pisciculturists might profitably turn their attention to the cultivation of a fish of such a peculiar and delicate flavour as the Smelt or Sparling.

In some parts of Sweden, as we are informed by Nilsson, Smelts are found in lakes with a sandy bottom all the year round. In the spring they leave the deep water and pass in thousands to the shallower shores of the rivers, where they are caught in numbers.

The finest Smelts I ever see come from the Conway, where they grow to the length of ten or even twelve inches; but the specimens usually exposed for sale in the fish-shops are much smaller. The Smelt is found in the Tay, the Frith of. Forth, and the Ure on the

* Pennant in a note says, "And not without reason, if we may depend on Linnæus, who says there are two varieties in the Baltic; the one which is called Nors, fotidissimus, stercoris instar, which in the early spring, when the peasants come to buy it, fills all the streets of Upsal with the smell. He adds that at this season agues reign there." 
Yorkshire coast. Large quantities are taken by nets in the Humber, in the Yare of Norfolk, where they grow to a large size, the estuary of the Thames, and the Medway. On the western coasts they are found in the Solway Frith, the Mersey, Dee, the Conway, and Dublin Bay.

I have no specimen before me as I write; I shall therefore give Dr. Günther's description: - "The height of the body is much less than the length of the head, which is one fourth or two ninths of the total (without caudal). Snout produced, much longer than the diameter of the eye; young examples have the eye comparatively larger. Vomerine teeth and anterior lingual teeth large, fang-like; posterior mandibulary teeth larger than the anterior ones, which form a double series, the inner series containing stronger teeth than the outer one. The maxillary extends to, or nearly to, the vertical from the hind margin of the orbit. Back transparent greenish, sides silvery."

The Smelt, which is the only British species belonging to this small genus, is found on the coasts and fresh waters of North and Central Europe.

The number of rays in the fins is

Dorsal is.

Pectoral 11 .

Ventral $s$.

Anal ${ }_{3-10}$. 




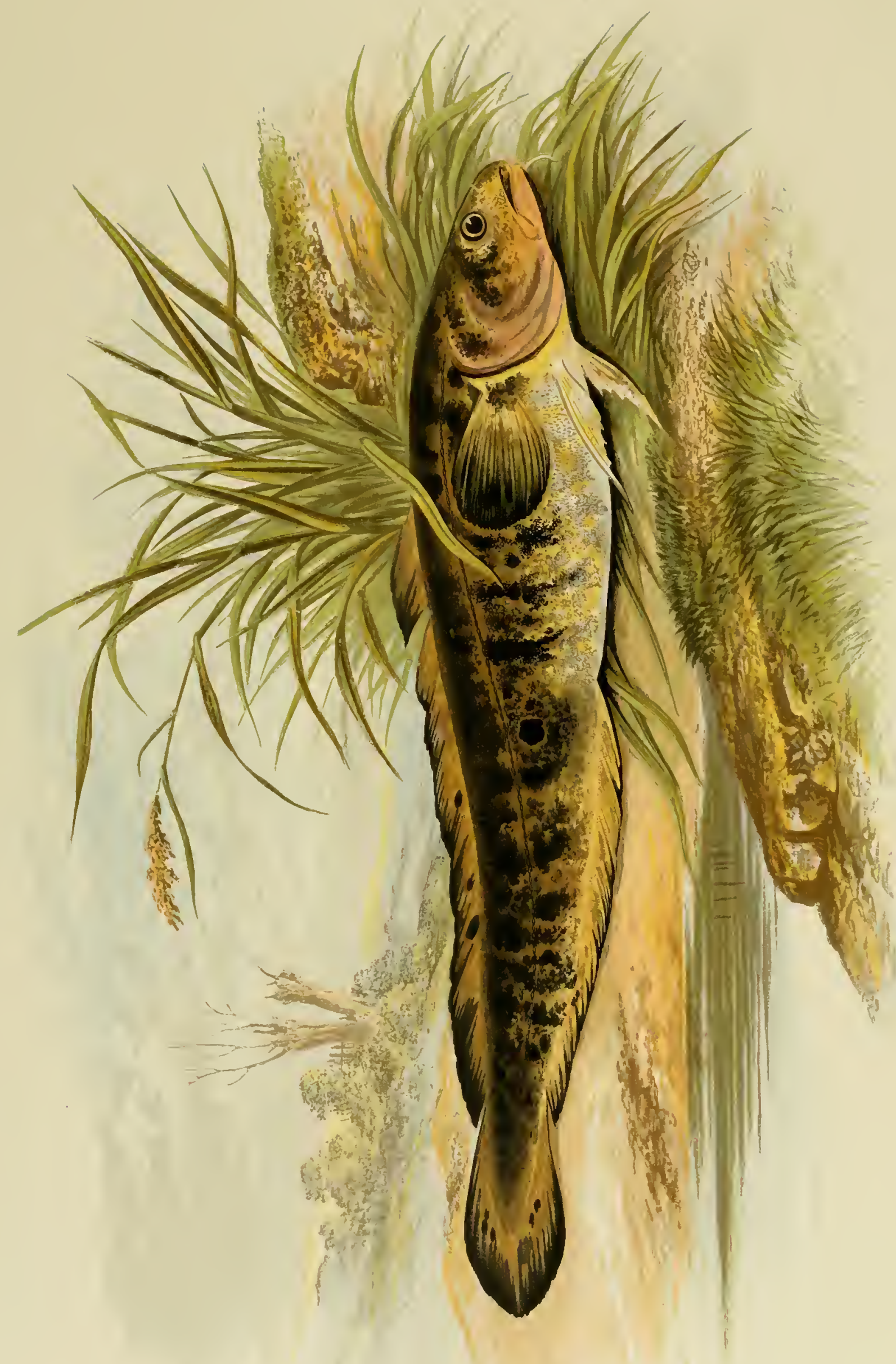




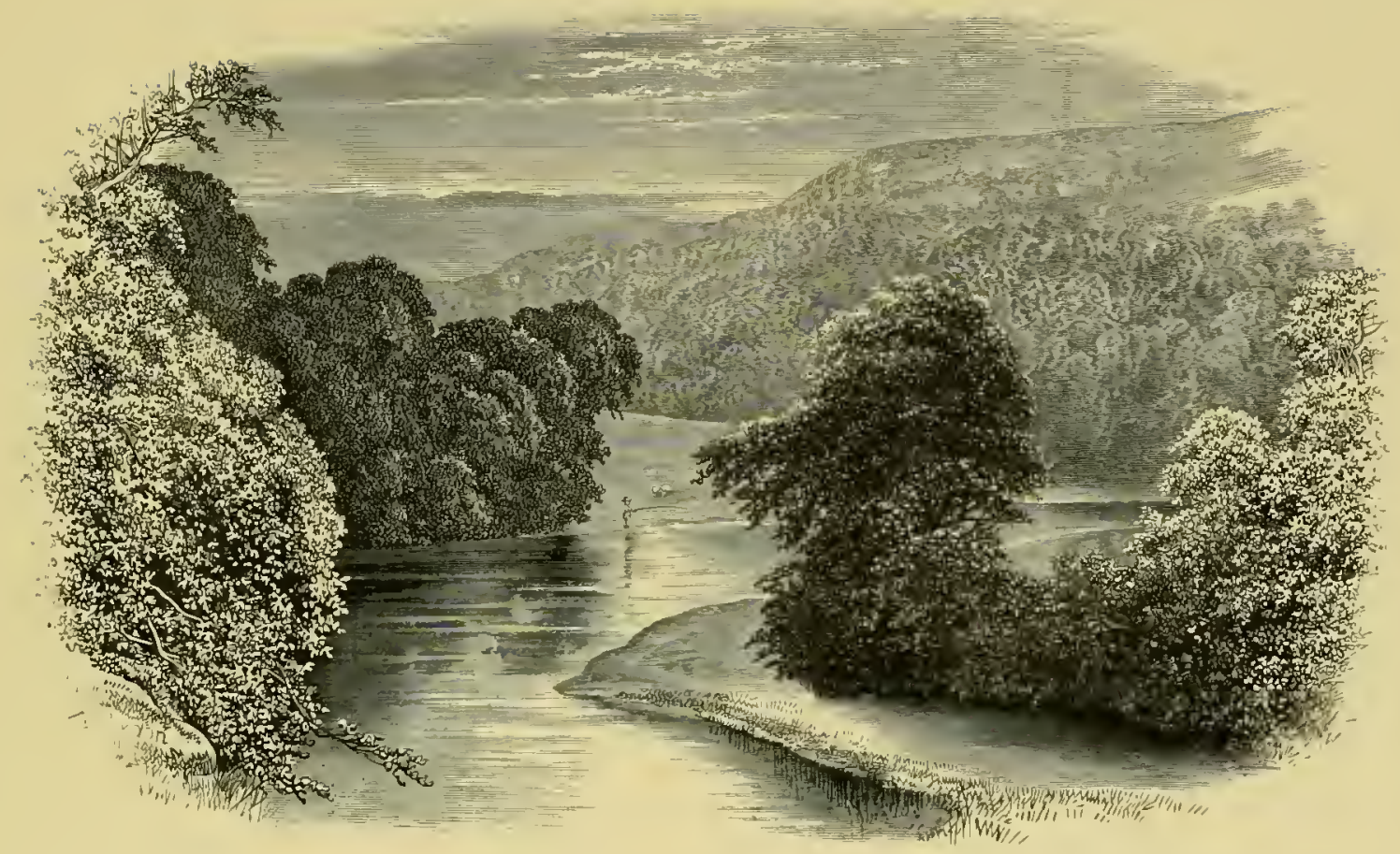

DN THE WHARFE.

Order $I I I$.

ANACANTHINI.

A. Anacanthini Gadoidei.
Family.

GADIDAE:

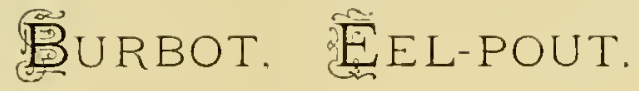

\section{(Lota vulgaris.)}

\author{
Mustcla, \\ Lota, \\ Wustela fluviatilis, nostratibus, Ecl-fout \\ nomine a Belgis mutuato, and Burlot \\ Gallico vocabulo dicta, \\ Gadus dorso triptrigio, on cirralu. \\ matillis coqualibus,
}

Gudus lota,

Burbol,

Lota rulgeris,

Burbolt, Burbot, Eil-pout,

Molza lota, Eil-pout, Coner-fish, Bird-Bull,
Pliny, Nat. Hist. ix. cap. I7.

Gesner, De Aquatil. p. 590.

Willegher, Hist. Pisc. 1'. 12, tal,. H. 3. fig. 4 .

Artedi, Spec. Pisc. p. $38, \mathrm{Nu}_{13}$.

Lin., Sy̆st. Nat. i. p. 440 ; LAcép., ii. 1) +35: Doxor., Brit. Fish. pli. 92. Pennant, Brit. Zool iii. P. 265.

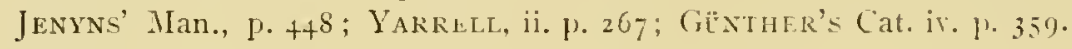
Couch, Fish. Brit. Isl. iii. p. 93, pl. $1+6$.

FLEAI., Brit. An., 1. I 22.

Characters of the Guns LorA.- "Lody elongate, covered with very small scales. A scparate caulal; two lorsal fins and one anal; ventrals narrow, composed of six rays. Villiform teeth of equal size in the jaws and on the romer; none on the palatines. The first dorsal with ten to thirteen well-developed rays. Chin with a barbel. Brancliostegals seven or eight. Fresh-water fishes of the temperate regions of the Northern Hemisphere."-Cit.vinek. 
THE Burbolt, Burbot, or Eel-pout is the only British species of the family of Gadide that 1 has its abode permanently in fresh water. This curious fish appears to have been known to, or at least to be mentioned by Pliny under the name of mustela, or "weasel-fish." He says, "The fish next (to the scarus) best for the table are the mustela, which, strange to say, the lake of Brigantia, in Rhætia, amongst the Alps, produces, rivalling the fish of the sea." According to some editions this fish was valued only for its liver; the Brigantine lake is the present Boden See, or Lake of Constance. In some parts of France it is said still to be called by the name of motclle, which I suppose is a corruption of mustela. The Lake of Constance still produces Burbots, and there are specimens now in the British Museum from that piece of water; there are also specimens from the Gotha River. Sweden, the river Elbe, Switzerland, and the south of Europe. American representatives of this fish are found in Canada and the adjoining parts of the United States. In our own country the Burbolt is rather a local fish. I have obtained, through the kindness of Mr. William Shelton, of the Grange, WVergs, Wolverhampton, specimens from the Penk, a tributary of the Trent, which river also produces it. According to Yarrell, the Nottingham market was, in his time, occasionally supplied with examples for sale. It is found in the rivers of Yorkshire and Durham, Norfolk, Lincolnshire, and Cambridgeshire. A good many years ago, Mrr. Masefield, of Ellerton Hall, had numbers of these fish in the fishponds on his estate; he used to prize them highly for the table, for the flesh is rich and delicious. I believe that a long and hard frost was the means of killing a number; at any rate the Burbot has ceased to exist in the Ellerton waters. Mr. Masefield is desirous to introduce them again into his ponds; and being hardy fish, there would be no difficulty about the matter, excepting that as they are generally caught with hooks on night-lines, the specimens are usually too much injured to survive long after being taken:

The Burbot does not occur in Scotland, nor is it included by Mr. Thompson among the fishes of Ireland. It prefers slowly-running rivers, but will thrive in still waters. Like the Eel--to which it bears some resemblance, hence, doubtless, its name Eel-pout*-the habits of this fish are to conceal itself under stones and deep banks, and on this account it has been called the Coney or Rabbit Fish, from its lurking nature. May the name of mustcla, mentioned by Pliny, refer to the same habits, associated in his day with those of the weasel? The spawning time is in March and April; but little, if anything, is known, I believe, of the young fry, or of the time required for the development of the ova. Bloch states that the spawning time is in December and January.

Pennant calls it a very delicate fish for the table, though of disgusting appearance when alive; says that it is very voracious, and preys on the fry and lesser fishes; that it will not often take a bait, but is generally caught in weels. Certainly the Burbot is a curious-looking fish, but Pennant was too much given to detect what he called the disgusting in nature.

In this country these fish seldom grow to a greater size than three or four pounds in weight; a more common size is about two pounds. According to Pennant, the largest British specimen he ever heard of was taken in the Trent by Sir Jervase Clifton, which weighed eight pounds; a fish of very unusual size. Lloyd is quoted by Couch as mentioning a Scandinavian specimen weighing twenty pounds.

The Burbot was known to Plot, who has some very quaint remarks about it. Of the fishes of this "inland county (Staffordshire) I could hear but of one," he says, "amongst them all that I think undescribed, and that one of the smooth sort without scales, and for its solitary way of living, of the $\sigma \pi$ opasıo,$\dagger$ there having not above four of them been catch't, that I

* Pout, I think, refers to a fuiler form of the belly than is seen in the Ecl, which to some extent reminds one of the belly of the Codfish, to which fish, indeed, it is related.

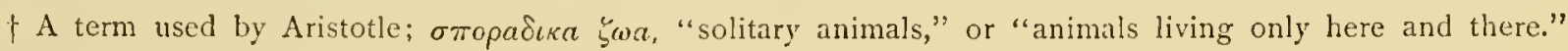


could hear of, within memory, and these all single and without any company, no, not so much as of their own kind." Plot's figure is as quaint as his language, but no doubt it is intended for the Burbot. He says, "However we may allow it to be a Mustela fluviatilis, though in Staffordshire, by some it is call'd a Burbot, or Bird-bolt, perhaps from that sort of Arrow, rounded at head, somewhat like these fishes; by others, from the oddness of the shape, and rarity of meeting them, the Non-such; there having never but four (that I could hear of) been found within memory." - (Natural History of Staffordshirc, by Robert Plot, ed. Oxford, I686.)

This fish is very deserving of cultivation, and I hope that pisciculturists will soon turn their attention to the Burbot.

I have no specimens before me as I write,-my own I presented to the Liverpool Museum, -I therefore take Yarrell's description, which I remember to be accurate. "The head depressed, smooth; jaws equal; chin with one barbule; the gape large, with small teeth above and below; eyes of moderate size; gill-opening large; the length of the head compared to that of the body as one to four; the form of the body cylindrical, compressed posteriorly. The first dorsal fin is small and rounded; the second elongated, reaching nearly to the tail; both dorsal fins nearly uniform in height; ventral fins placed very forward, narrow and pointed; the pectoral fins large and rounded: the anal fin begins on a line behind the commencement of the second dorsal fin, but ends very nearly on the same plane; the tail oval and slightly pointed.

The fin rays in number are

\author{
Dorsals 14.68 . \\ Pectoral 20. \\ Ventral 6. \\ Anal 67 .
}

The colour of the body is yellowish brown, clouded and spotted with darker brown, and covered with a mucous secretion; the under parts lighter; scales small; the fins partaling of the part of the body from which they emanate, those of the lower surface being much the lighteșt."

The word Burbot, probably, is to be referred to barba and barbatus, "beard," "bearded," in allusion to the barbule with which the under jaw is furnished. Continental names of this fish are Die Quappe, Aalraupe, Treische, La Lottc, etc.

The specimen which supplied the illustration was caught in the neighbourhood of Driffield. 




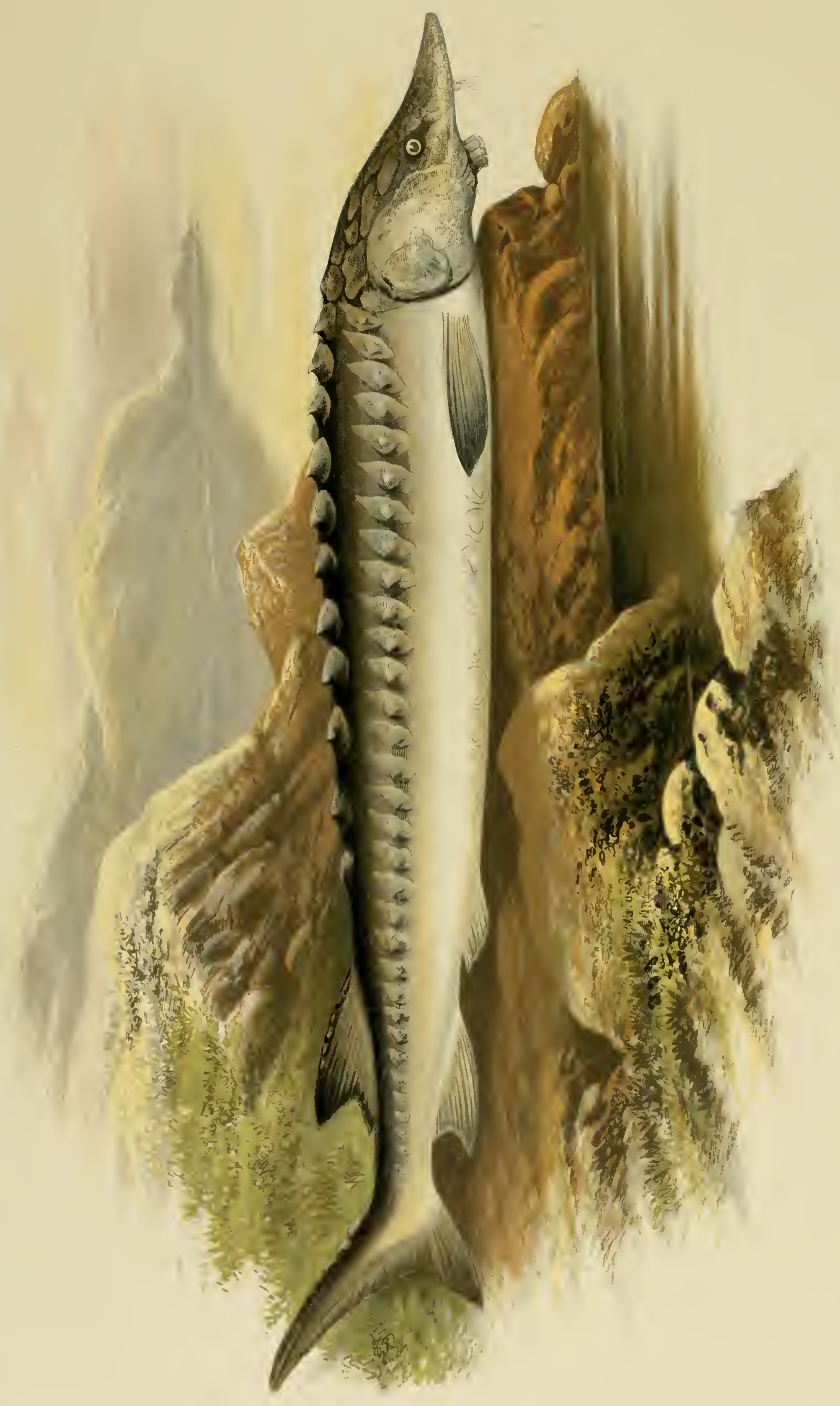




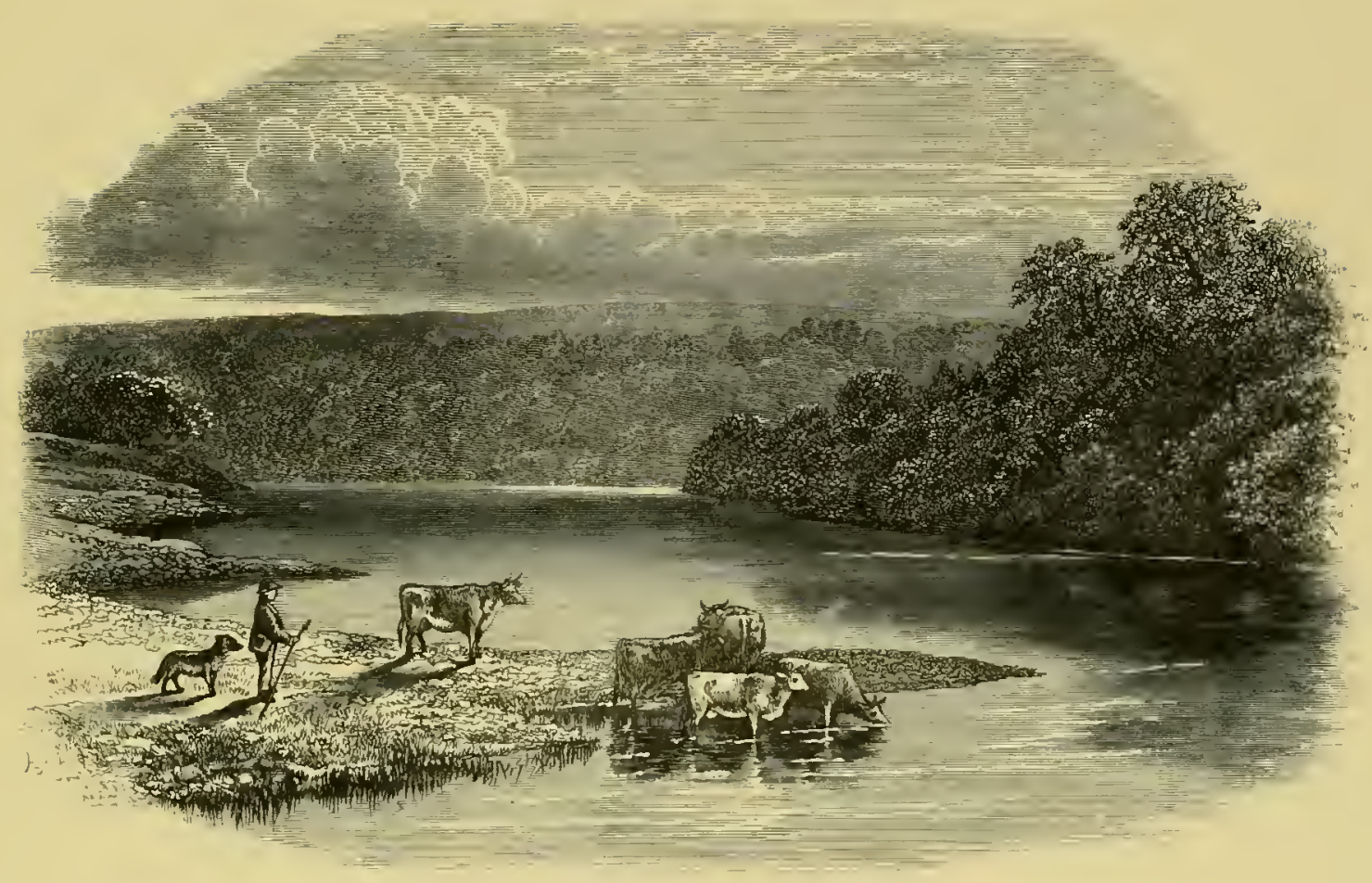

ON THE PEE.

Sub-class-GaNOIDEI.

Order II.

CHONDROSTEI.
Family

ACIPENSERIDA.

\section{STURGEON.}

\section{(Acipenser sturio.)}

Attilus,

Sturio,

Acipenser corpore

Acipenser sturio,

Sturgeon,

Acipenser latirostris,
Gesner, De Aquatil. p. 109; Willughby, Hist. Pisc. P. $24 \mathrm{I}$, tab. P. 7, fig. 3 .

Gesner, De Aquatil. p. 931; Willughby, Hist. Pisc. p. 239. Artedi, Spec. Pisc. p. 9I, No. I.

Lin., Sys. Nat., i. p. 103: Lacerp., i. p. +1 ; Donovan, Brit. Fish. pl. 65; PARneld, Mem. Wern. Soc. vii. p. 403; Jenyns' Man. p. 493; Fleming, Hist. Anim. p. I73; Yarrell, ii. p. +75 ; Siebold, Süsserwasserf. p. $36_{3}$; GüntheR's Cat. viii. p. $3+^{2}$.

Pennant, Brit. Zool. iii. p. 164, ed. 1812 ; Couch, Fish. Brit. Isl. i. p. 157 , pl. 35 .

I'ARNeld, MIem. Wern. Soc. vii. p. to5; Y'arkell, ii. p. 479 .

Characters of the Genus ACipenser.- "The rows of osseus scutes not confluent on the tail. Spiracles present. Caudal rays surrounding the extremity of the tail. Inhabitants of the temperate and arctic regions of the northern hemisphere, periodically entering rivers. Some species entirely confined to fresh water. The geographical distribution of the Sturgeons is nearly identical with that of Salmo."-Günther. 
AL the British fresh-water species, which up to this place have occupied our attention,

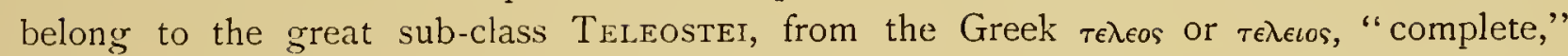
and oбтєov, "a bone," since all the individuals belonging to it possess an ossified skeleton, and completely separated vertebræ.

The Sturgeon comes under the sub-class Ganorder, in which the fishes have a skeleton more or less ossified. In this sub-class there are two orders-

I. Hotostci, in which the body is covered with scales, and the skeleton bony, and

II. Chondrostei, in which the skin is naked, or with bony bucklers.

In the first order there are no British species of fish. To the second the Sturgeon family (Acipenserida) belongs; it is thus characterized by Dr. Günther:- "Body elongate, subcylindrical, with five rows of osseous bucklers. Snout produced, subspatulate, or conical, with the mouth at its lower surface, small, transverse, protractile, toothless. Nostrils double in front of the eye. Four barbels in a transverse series on the lower side of the snout. Vertical fins with a single series of fulcra in front. Dorsal and anal fins approximate to the caudal, which is heterocercal. Gill membranes confluent at the throat, and attached to the isthmus. Branchiostegals none; gills four; two accessory gills. Air-bladder large, simple, communicating with the dorsal wall of the osophagus. Stomach without blind sac. Pancreas divided into pyloric appendages. Rectum with a spiral valve."-(Catalogue, viii. p. 332.)

The Sturgeon, occurring as it does in the Mediterranean, was in all probability known to the ancient Greeks and Romans; other species of the family may also have been known

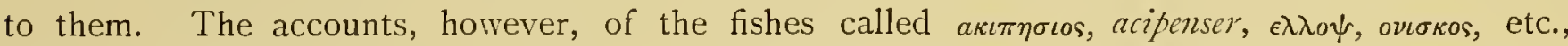
are so unsatisfactory, that we can do little more than form a conjecture that some species of Sturgeon is intended by all these various names.

This fish is occasionally taken in Salmon nets on various parts of our coasts; generally speaking, in the estuaries, or not far up the rivers; sometimes, however, it ascends rivers to a considerable distance. A specimen, eight feet long, and weighing one hundred and ninety-two pounds, was caught in the Severn, in 1802, in a weir near Shrewsbury. It has been taken in the Trent, near Nottingham. The antiquarian Aubrey, records it as commonly reported, that before an heir of Clifton of Clifton, in Nottinghamshire, dies, a Sturgeon is caught in the river Trent near that place.

The spawning time is in the winter and early spring, when the fish ascend the fresh water of the larger rivers. The spawn consists of roe or small grains shed in the same manner as that of the Tclcostei, or bony fishes. This Sturgeon's roe is the caviar of commerce, a thing, in my opinion, disgusting in appearance, offensive to the smell, and horrible to the taste. The Sturgeons supply the greater part of this, so called, relish. It is prepared near the mouths of the Volga, Danube, Dnieper, and Don. "In the month of Narch, the Sturgeon arrives in great numbers for spawning at these places. The ovaria of the largest of these fish are estimated to contain three millions of eggs. The fish are caught both with nets and hooks. Caviar is prepared by removing from the roe all its membranes; it is then washed in vinegar or white wine, and dried by being spread on a board in the air. After this it is thoroughly salted, the salt being rubbed in with the hand; it is then put into a bag, and pressed in order to remove the liquor; finally it is packed in kegs, and is then ready for sale. The caviar made on the shores of the Caspian is for the most part sent up the Volga to Noscow; that shipped from the ports of the Black Sea and Sea of Azof, is bought at Astrakhan by the Armenians of Nakhitchivan and the Greeks of Taganrog. This caviar is not so good as that which is made on the Caspian. The principal exports are to Italy: very little is brought to England. The shipments altogether form only a small part of what is made, the consumption in Russia being very great, in consequence of the three seasons of fasting which occur in the year. There has been known to be as much as one thousand 
hundredweights of caviar shipped from Odessa in a single year; but this is far beneath the produce of the Caspian, which has in some years reached fifteen thousand hundredweights. When of good quality, caviar is dry and of a brown colour; it is commonly eaten with oil and lemon juice. A cheaper and less prized kind is obtained from the roe of the Grey Mullet, and from some species of Carp, which are common in and near the Black Sea."(English Cyclop. Arts and Science Div. ii. p. 69r.) According to M. Littré, the name caviare is derived from the Turkish chouiar; what that means I do not know. The word to me, when I see the substance on the breakfast table, always suggests caution, and I associate it, wrongly I know, but feelingly, with the Latin word cave!

The membrane of the air-bladder of the Sturgeon supplies isinglass, a substance known to the ancient Greeks and Romans under the name of ichthyocolla, "fish-glue." Russia supplies most of the isinglass of commerce. The thick air-bladder ("sounds") is washed in cold water, and exposed for a short time to the air, in order to stiffen. "The outer skin is then taken off and rejected, and the remainder cut out, and loosely twisted into rolls, according to the intended size of the pieces, which are called staples, and are known in commerce by the names of long and short staple, and of these the first is the best. These are dried in the air. The best sort of isinglass is used for the table and in confectionary; it is also largely employed in refining wine and beer."-(Engl. Cycl. iv. p. 998.)

I have never tasted a Sturgeon, and should not know how to cook it. Yarrell says it is generally stewed with rich gravy, and the flavour is considered to be like that of veal. Being a cartilaginous fish, the flesh is doubtless very nutritious.

The Sturgeon grows to a great size. One of the largest British specimens on record is mentioned by Pennant; it was caught in the Esk, and weighed four hundred and sixty pounds. In the aquarium at Southport, one of the best, if not the best aquarium in the kingdom, specimens of Sturgeons are often to be seen swimming about in the great tanks. In a letter from Mr. Jackson, the Curator, kindly written to me in October, i 878 , I learn that there were then two Sturgeons living at the aquarium. "One was caught last summer; the other, a very fine specimen, seven feet long, was caught three years last August; it feeds freely on lug-worms, and is in fine condition. The Sturgeons are always kept by us in salt water, which prevents fish in general from being, attacked by parasitic epizoa, which is not the case in fresh water." Pennant's fish has lately been thrown quite into the shade, as will be seen from the following extract from the Lecds Mircury of February Ist., 1879:"The largest Sturgeon ever delivered at the port was brought into Grimsby on Wednesday morning by the smack 'The Kitty,' (S. Shelton, master), Mr. Smethurst, Jun., owner. The Sturgeon was four feet eleven inches in circumference, eleven feet nine inches in length, and weighed forty-four stones and a half. It was sold to Mr. A. Clifton, fish merchant.'

The mouth of the Sturgeon, which is in the form of a sucker, is situated on the under side of the head, not far from the feelers, or cirri, which, being well supplied with nerves, are able to point out to this fish the food with which it meets as it pokes about with its pointed snout.

"When caught in the Thames, within the jurisdiction of the Lord Mayor," says Yarrell, "the Sturgeon is considered a royal fish; the term being intended to imply that it ought to be sent to the king, and it is said that this fish was exclusively reserved for the table of Henry the First of England.'

The fish thought by Parnell to be a distinct species, to which he gave the name of Acipenscr latirostris, is by Dr. Günther referred to a variety of the Common Sturgeon, $A$. sturio. It appears, however, that the American species, $A$. maculosus, has been taken from the Firth of Tay. This is the A. thompsoni of Richardson, in the third edition of Yarrell's British Fishes, ii., 456, (see Günther's Catalogue, viii., p. 339, note). The Acipinscr sturio is thus described:- "Snout pointed, produced, it being equal to, or but little shorter than, the 
remaining part of the head in examples to three feet long. Barbels nearer to the eye than to the extremity of the snout; in very large examples, especially those with a broad snout, the barbels are midway between snout and eye, or even nearer to the end of the snout. Osseous shields well developed: I I-I 3 along the back, and (34) 29-3 I (in young examples sometimes 26 or 27 ) along the side. Skin with very small rough points in very young examples; in older ones these ossifications are broader, rough, substellate, and more or less regularly arranged in oblique series. Anal fin below dorsal. Dorsal 37-44." This species is found in the Mediterranean, western and northern Europe, and eastern North America.

The word Sturgeon is to be referred to the German Stör, the name of this fish; perhaps the term may be connected with the verb stören, "to poke," "rummage about," in allusion to this fish seeking its food at the bottom with its pointed head. 
"TTHERE are few animals," says a celebrated French naturalist, "whose image one must

1 retrace with as much pleasure as the Common Eel......We have seen superior instinct in the enormous and terrible shark, but then it was the minister of an unsatiable voracity, a sanguinary cruelty, a devastating strength; we have found in electrical fish, a power which we may almost call magical, but beauty did not fall to their share. We have had to represent remarkable forms, but nearly always their colours were dull and dark. Glittering shades have struck our view; rarely have they been united with pleasing proportions, more rarely still have they served to adorn a creature of elevated instinct. And this kind of intelligence, this mixture of the glitter of metals, of the colours of the rainbow, this rare conformation of all the parts which form one whole joined in happy agreement, when have we seen all these bestowed where the habits are, so to speak, social, the affections gentle, and the enjoyments in some sort sentimental? It is this interesting union, however, which we are going to show in the Common Eel; and when we shall have comprised into one point of view its slender form, its delicate proportions, its elegant colours, its gracious flexions, its easy gyrations, its rapid springs, its superior swimming, its serpent-like movements, its industry, its instinct, its affection for its mate, its sociability, and the advantages which man is ever deriving from it, we shall not be surprised to find that some of the Greek and Roman ladies most famous for their charms have given its form to one of their most recherchés ornaments." * While allowing that the language "verges on the poetical," I must confess a partiality for Eels, and own that there is a great deal of truth in what the French naturalist has said. But then we must think of the Eel as a free and unmolested inhabitant of the water, and not as a writhing victim on the fishing-line of some disciple of Walton, when he certainly is a troublesome fellow, and when we may fairly say of him, "Nihil tetigit quod non fadavit." The Eel, however, has long enjoyed, and still deservedly enjoys, a wide celebrity. "It is agreed," says honest Izaak Walton, "that the Eel is a most dainty dish; the Romans have esteemed her the Helcna of their feasts, and some the queen of palate pleasure." There are a few exceptions, however, to this general rule. The Jews-excellent cooks and judges of what is good-refuse to eat the Eel at this very day, though they are perfectly aware that it has scales. $\dagger$ Amongst

* Euvres du Comte de Lacépede, vi. p. 457 .

$\dagger$ It is an error to suppose that the Jews are unacquainted with the fact that Eels have scales. According to the popular belief, the celebrated Leuwenhoek was the first to record the existence of scales in the integument of the Eel. To this observant naturalist probably belongs the merit of having first published the fact to the scientific world of modern Europe; but that the Jew's were long before aware of it is evident from a certain narrative in the Talmud (Abada Sara, fol. 39, a.), which relates that when Rabbi Aschi came to Tamdoria, some one placed before him an Eel-like fish (TSELopeкha, which Rashi explains by "anguille"); and that on his holding it to the light, he noticed some very fine scales, and thereupon did not scruple to partake of its flesh. That the Hebrew word denotes an Eel is further evident from the following quotation from the old work Aruch- "TSELOBEKHA, a fish 
the Scotch there is a great antipathy to Eels; whence derived one cannot say, unless from an objection to their snake-like form.* I have known Englishmen make this objection. To a question in Notcs and Querics (Sept. 26th., I 863), as to whether the Scotch have any definite reason for their dislike of this fish, the following reply is given:-- "It would appear from Partington's British Cyclopadia, that the Scottish objection to Eels as an article of food, is mainly due to their supposed unwholesomeness. In the northern part of Britain, in Scotland especially, the prejudice of the people runs very strong, not only against the form of the Eel, but against the quality of its fesh as an article of food." And again, "Eels are held in small estimation in the North; and, even discounting their serpent-form, they are regarded as far from wholesome." I shall refer by and bye to the supposed unwholesomeness of this fish. I have been told of a Scotch lady who once tasted Eel inadvertently, and thought it excellent; but on finding out what it was would eat no more, and has never tasted it since.

To the naturalist the Eel is a subject of particular interest, chiefly on account of the difficulty which has hitherto attended the study of its history; and although it is certain that Eels are produced after the manner of fish generally, i.e., from deposited ova, much yet remains in obscurity. To this point I must revert again.

The difficulty of holding an Eel has given rise to many proverbs. "Every one knows who may have tried the experiment," happily observes Dr. Badham, "every one knows that to hold an Eel with the naked hand, is as abortive an attempt as detaining a pig by the tail, after it has been well soaped; or, in morals, to hold a knave to his word. Hence the apophthegm, $†$ 'Anguilla est, elabitur,' 'He's an Eel, and is off;' but both rogue and Eel may be held tight if we set about it in the right way." The ancient method of retaining an Eel was by seizing it with some rough leaf in the hand. The fig-leaf was usually employed: hence the proverb, $\tau \omega \theta \rho \iota \omega \tau \eta \nu \in \gamma \chi \epsilon \lambda \nu \nu$, "an Eel with a fig-leaf." $\ddagger$ Alciati has the following epigram upon a captured rogue:-

\footnotetext{
"Jamdudum quocunque fugis te persequor, at nunc Cassibus in nostris denique captus ades.

Amplius haud poteris vires eludere nostras,

Ficulno anguillum strinximus in folio." - Emb. ed. I540.
}

Modern fishermen know how to retain an Eel in the naked hand without any extraneous lelp. There is, however, but one successful mode, viz. to grasp the slippery beast in the middle with the second and third fingers above and the first and fourth below. He is thus held as in a vice. Gesner quotes the Greek proverb, a $\pi^{\prime}$ ovpas $\tau \eta \nu \in \gamma \chi \epsilon \lambda \nu \nu \in \chi \epsilon \iota$, "You've an

unclean amongst the Jews, thin, round, and like a serpent, which on account of its slipperiness can only be retained in the hand by being covered with sand or dust." According to the Aruch, the Eel bears the same name in Arabic, though a more usual Arabic designation is ENkELIs, which is evidently the Greek $\epsilon \gamma \chi \epsilon \lambda \nu s$. The modern Jews, doubtless, still object to the Eel on account of its snake-like form. See Buxtorf's Lex. Tulm. tt Rabbin. p. igro; Lewysohn's Zoologie des Talmuds, p. $26+$.

* Hence the Latin anguilla, from anguis, "a snake." Compare Juvenal, Sat. v. 103. "Vos anguilla manet longx cognata colubræ." Similarly the French, Italian, and Spanish words; also the English "snig" (snakc), sometimes used to denote the middle-nosed variety, but often, in a general sense, any Eel. "Eil," German and Dutch aal, according to Wedgwood, is from the Finnish ilja, iljakka, "slimy," or the Esthonian illa, "slime."

† Plautus Pseud. II. 4. 57 .

+ According to the Hirroglyphica, size de Sacris Assptionum Commentarii, of J. P. Valerian Bolzani, Basil, 1755. lib. xxix. De Anguillâ, the fig-leaf was used for this purpose by the ancient ligyptians; for when they wished to denote "certainty with regard to an uncertain object," spes certa re super ambigua, they depicted an Eel rolled up in a fig-leaf. It is curious to note the correspondence of ideas, between the Egyptians and Greeks in this matter of the allegorical meaning of the Fel. Bolzani states that the picture of "an Eel held by the tail" denoted "a man vainly pursuing a fugitive object;" and the representation of a man engaged in catching Eels, was meant to typify "one who was growing rich from civil discord," such as Cicero represents Catiline and his co-conspirators, when he speaks of them as men "qui, honores, quos quieta republica desperant, perturbata se consequi posse arbitrantur." In I. Cat. ii. cap. ix. See further on. 
Eel by the tail," as expressing either a man "lubrica fide"- "a slippery fellow," or an object which it is impossible to retain. The same proverb has found its way into German, "Du hast den Aale bei dem Schwanz." The slippery nature and line-entangling propensities of the Eel are often the subject of much merriment. Who does not remember, as depicted by the pencil of John Leech, the disconsolate look of poor Mr. Briggs as he holds up on the end of his fishing-line a whacking Thames Eel, that has twisted that said line into the most inextricable conglomeration of worse than Gordian knots? Or who can ever forget the scene of the bursting of the aquarium-the conception of the same inimitable artist-and the vain efforts of the old lady to pick up her favourite Eel with a pair of tongs!

Eels were held in high, and indeed in very absurdly high, repute by the ancients. As to the Egyptians, they paid the Eel so great a compliment as to enrol it amongst their gods. Only another fish, if Herodotus is correct, shared this honour with the Eel, and that was known by the name of lepidôtus, some fish probably of the Carp family, and so called from the large size of its scales.* Antiphanest ridicules the Egyptians for the honour they paid to Eels, and contrasts the value of the gods with the high price asked for this fish in the market of Athens. "In other respects men say that the Egyptians are clever, in that they esteem the Eel to be equal to a god; but they are far more valuable than the gods, for we can propitiate them by prayer; but as for Eels, we must spend twelve drachmas or more merely to get a smell at them." And Anaxandrides thus amusingly contrasts the manners of the Egyptians with those of his fellow-countrymen. "I never could associate with you, for neither do our customs nor laws agree with yours, but differ widely. You adore an ox, I sacrifice him to the gods; you esteem an Eel as the greatest deity, we think him far the best of fish; you don't eat swine's flesh, I am particularly fond of it; you worship a dog, I beat him if I ever catch him devouring my victuals," \&c.

The ancient Greeks carried their partiality for the Eel to a most ridiculous excess; now she is invoked "as the goddess of pleasure, sometimes as the white-armed goddess-and, finally, as the Helen of the dinner-table, because every guest strove, like Paris, to supplant his neighbour, and keep her for himself." $\$$ The Eels from the river Strymon and lake of Copais appear to have been those generally most highly prized, though Sicily was also celebrated.\| Archestratus, 9 of Syracuse, who appears to have been a sort of ancient Soyer, and who travelled far and wide for the purpose of learning anything that might be useful in the culinary art-whose opinion, therefore, we may be content to take in this questionnaturally gives the preference to Eels from his own shores. The Greeks, in the time of Aristophanes, used to serve up their Eels with beetroot, though sometimes they were boiled in salt and water, with marjoram and other herbs. Eubulus*** is quoted as saying,-

"then there came

Those natives of the lake, the holy Ecls,

Bocotian goddesses, all clothed in beet."

The ancients sometimes captured Eels by means of hools baited with large worms or small fish. Aristotlett mentions a three-pronged spear (

* ii. 72 .

+ Apud Athenæus, vii. 55, ed. Dindorf.

† Ibid.

Srose Halieutics, p. $38 \mathrm{I}$.

\| The Strymon is the modern Struma or Carasu, which flows through the Lake Prasias (now Takino). The Eels that formerly abounded there were doubtless an attraction to the numbers of cranes (Strymonia grues) frequently mentioned by ancient writers. Belon (Les Obsirvations, p. I24) speaks of the large size of the Eels of the Strymon: "Les anguilles y sont d'une excessive grandeur." The Lake Copais (now Topolias) is still famous for its Eels. In the dark recesses of the subterraneous channels which form the outlets of the lake Eels would find a congenial habitation.

9 Athenæus, vii. 53, Younge's translation.

** Athen. vii. 56 .

It Hist. Anim. iv. 10, $\S$; 
common Eel-spear-which was used by the Greek fishermen to take the Flat-fish (Pleuronecfidc) on the sand. He also says that Eels in the Strymon were taken at the time of the rising of the Pleiades, when the stormy winds stirred up the mud, and that at other times it was useless to try to obtain them.* In modern days the best time for catching large numbers of Eels is after heavy storms and floods. Aristotle gives as a reason for their being caught at these times, that Eels having small gills are soon suffocated if the water is muddy. The following ingenious mode of angling as adopted by the Grecian youth is given by Oppian :- +

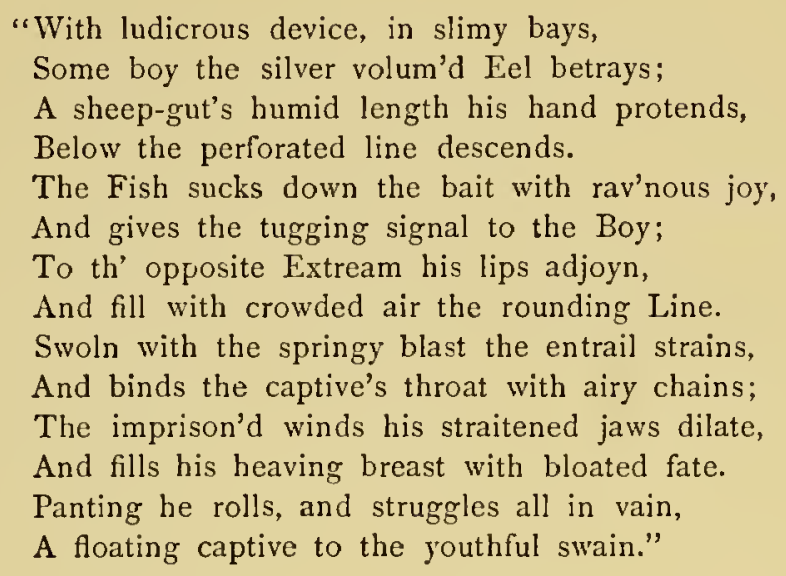

Eels were also taken in wicker baskets with narrow necks, $\neq$ as with the moderns; they were sometimes decoyed into earthenware vessels covered with colander-shaped lids, and baited with bits of cuttle-fish or other tempting morsels; $\$$ they were kept by the Romans in their fish-ponds (vivaria), ready at hand for the table when required. Pliny states that immense numbers of Eels used to be taken in the lake Benacus (Lago di Garda), in the territory of Verona,-through which lake the river Mincius flows,-generally in the month of October, when the waters were disturbed, and that masses of more than a thousand in number were often taken by the traps (excipulis) placed in the stream. Eels were sometimes caught by stirring up the mud of the ponds and lakes in which they were found; hence the Greek

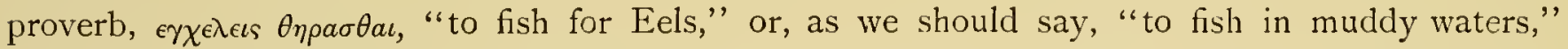
with the political meaning of disturbing a state for the sake of gain; thus the sausage seller addresses Cleon, "Yes, for it is with you as with Eel-catchers, when the lake is still they take nothing, but if they stir up the mud they have good sport; so have you when you disturb the state."

It is well known that the mode of procreation of Eels has for ages been a puzzling question; and there is still something wanted to complete our knowledge of the general subject. Aristotle, after asserting that Eels are not produced from ova, or, as some persons have stated, from the metamorphosis of intestinal worms into young Eels, goes on to tell us what he conceives to be the true mode of generation. "They are produced from what are called the entrails of the earth $(\epsilon \kappa \tau \omega \nu \kappa a \lambda o \nu \mu \epsilon \nu \omega \nu \gamma \eta \varsigma \epsilon \nu \tau \epsilon \rho \omega \nu)$, which exist spontaneously in mud and wet earth. Some have been observed to make their escape from these things, and others have been apparent in them on being dissected. Such things are produced in the sea, and in rivers where is much putrefaction, in such places in the sea which abound in sea-weed,

* Historia Animalium, viii. 4 , §5, ed. Schneider.

$\dagger$ Halicutics, iv. 559, Jones's translation. Fian (Nat. Hist., xiv. 8) has described a similar mode of catching Eels. The modern method of "bobbing with a bunch of grubs strung on worsted," if not so ingenious, is doubtless more successful.

† Nassis. "Nassa est piscatorii vasi genus, quo cum intravit piscis, exire non potest."-Festus, s.

§ Hist. Anim. iv. 8. § 12. \| Aristoph., Nitb., 559. 
and in rivers and lakes near the banks where the heat of the sun engenders putrefaction."** Aristotle believed that there was no difference of sex in the Eel, but that the so-called male and female were different species. He speaks correctly, however, of its migrating to the sea, of its nocturnal habits, of its dislike to very cold, and its love of pure fresh water. $\dagger$ Pliny's notion was as absurd as that of Aristotle as to the origin of Eels. "They rub themselves against rocks, and their scrapings come to life. Nor have they any other mode of propagation." $\ddagger$

Other ancient writers were of opinion that Eels originated in the carcases of dead horses (as Virgil supposed bees were produced from the dead body of an ox). Curiously enough, Gesner sees no improbability in the above solution of the difficulty, but thinks that other carcases besides those of horses may engender Eels.\$ And yet he does also give the true account when he says that the sexes are plainly to be distinguished.\| It is remarkable, therefore, that Gesner should have had recourse to the "spontaneous production" theory; but we must remember that in his time this was a popular creed; and even this learned writer was not free from the fallacies of his age. Helmont gives the following recipe for obtaining young Eels:- "Cut up two turfs covered with May-dew, and lay one upon the other, the grassy sides inwards, and thus expose them to the heat of the sun; in a few hours there will spring from them an infinite quantity of Eels." Some writers, as Schwenckfeld and Schoneveld, appear to have mistaken parasitic leeches and Gordian worms for the young of the Eel. Chopped horse-hair, thrown into the water, was deemed a certain method of obtaining Eels; this opinion I have found to prevail amongst the uneducated classes to this day in some of the midland counties. 9 It is remarkable that even Walton seems to have imbibed contentedly the popular notions of his day, "That Eels may be bred as some worms, and some kind of bees and wasps are, seems to be made probable by the barnacles and young goslings bred by the sun's heat and the rotten planks of an old ship, and hatched of trees." ***--(P. 28I.)

In another place Walton affirms his belief in the notion that Pike were sometimes produced from pickerel weed (p. 230). Such superstitions find a place in the "Piscatory Eclogues."

\footnotetext{
"Say, canst thou tell how worms of moisture breed,

Or pike are gendered of the pickrel-weed?

How carp without the parent seed renew,

Or slimy Eels are form'd of genial dew?"
}

The opinion that Eels are viviparous, though quite free from the absurdity that characterises the notions I have already mentioned, is unquestionably erroneous. It is not a little remarkable that the anatomy of the fish should not have been earlier ascertained. "Who can say," writes Dr. Badham as late as 1854 , "that they have taken a female in roe, or tasted a male's milt?" If you ask a fishmonger whether he has ever seen the spawn of an Eel, he will think you are joking with him, and will probably consider "Eel's spawn" to be nearly analogous to "a mare's nest," or "pigeon's milk!"

* Hist. Anim. vi. ${ }_{15}, \S 2$. † Hist. Anim. vi. $13, \S 7$; viii. $4, \S 5,6$.

† Nat. Hist. ix. 5o. Oppian's theory will be found at Hal. i. $8+9$.

§ "In putredine gignitur Anguilla ut vermes in terra, id quod experientia compertum fuit. Aliquando enim equo mortuo in Magalonæ stagnum injecto, paullo post innumerabiles Anguillæ illic visæ sunt, quod ego ita accipio ut non ex equi tantum, sed etiam ex aliorum animalium cadaveribus generentur."-De Aquatilibus, iii. p. fo, C.

|| "Vidi equidem Anguillas mutuo corporum complexu coëuntes, neque puto partibus ad gignendum necesariis prorsus destitutas esse: inferiore enim ventris parte et vulva in fominis et semen in maribus reperitur: sed pinguitudine multa circumfusæ hæ partes non apparent, quemadmodum neque ova pinguitudine permista."-Ibid., p. $4^{2}$, D.

I I have been informed that the same mode of accounting for the origin of Eels exists amongst the unlearned in Scotland.

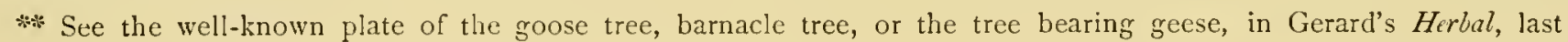
plate. 
C. U. Ekström says, "I have never found roe in the body of the Eel, but I nevertheless believe that it is through the deposit of eggs that the fish propagates its species." There can be little doubt that the belief in the viviparous nature of the Eel may be traced to the fact of the presence of intestinal worms in the stomach and intestines. These worms, several kinds of which are described by Diesing* as inhabiting the genus Anguilla, have been ignorantly taken for young Eels.

But although the oviparous nature of the Eel is established beyond a shadow of doubt, and the anatomy of the fish clearly ascertained, still we have by no means all the information we require on the general question. That Eels descend rivers to the sea for the sake of depositing their spawn in the brackish water of estuaries where the increased temperature of the water is favourable to their habits, $\dagger$ has been long known. Aristotle alludes to the fact, and clivers observers in modern times have recorded it. But do these Eels ever again ascend the rivers, or do they remain in the sea and estuaries? At what season of the year are the eggs deposited? Is it nccessary that Eels should descend to the sea for spawning, or do they propagate their species in ponds and fresh water?

Before I remark on these questions, I should state that there are two species of Eel indigenous to the British Isles, viz., the Common Eel (Anguilla vulgaris), and the Bluntnosed (A. latirostris). The Blunt-nose is widely distributed, but does not appear to be nearly so abundant as the other species; it is probably the "Frog-mouthed Eel" "of the Severn fishermen; it is described as being a fiercer and more voracious fish than the other species, dashing at and seizing its prey as a terrier does a rat, and filthy in the extreme in the nature of its food." + It seldom exceeds five pounds in weight. Mr. Francis, whose name is well known in connection with the new Art of Pisciculture, describes the Blunt-nose as "a coarse worthless fish." Such is my own opinion. Surely it was Blunt-nose that fattened on the body of Asteropzus.

"When roll'd between the banks, it lay the food

Of curling Eels and fishes of the flood."-Iliad, xxi. 22 I.

According to an authority quoted by Mr. Cholmondeley Pennell in his work (The Angler Naturalist), the Broad-nosed Eel does not migrate. The same writer states that the contractors for the fishery of the Toome "expressly stipulate that they will not take a single Broad-nosed Eel," but always throw them aside.

With regard to the question whether the Eels that have descended to the sea from the lakes and rivers return again, or whether they remain in the brackish estuaries, I cannot give any decided opinion. Many persons have witnessed the ascent of countless thousands of young Eels or elvers from the estuaries and the sea, and no one, I believe, has ever seen adult Eels accompanying the elvers, or journeying by themselves. Yarrell says that the return of adult Eels is shown by the habits and success of the basket-fishermen in rivers within the tide way, who place the mouths of their Eel-pots up stream in autumn, and down stream in the spring. The question must still be regarded as problematic. Another difficult matter to determine is the time of the deposition of the ova. From some notes kindly put into my hands by Mr. Jonathan Couch, some few years ago, it would appear that Eels breed almost throughout the year. Young Eels of very small size have been found on the sea-beach of Polperro, in Cornwall, so early in the year as the beginning of January. Early in March

* Systema Melminthum, ii. p. 3 So.

† "The mixed water is shown by experiment to maintain a temperature two degrees higher than the pure sea or fresh water, from the combination of the fluids of different densities."

+ The Angler Naturalist, p. 398 .

See the Ingoldsby Legends-"The Knight and the Lady," p. +78 , ed. i $86 z$. 
Mr. Couch has seen them migrating in immense numbers up the river near his house, and "from this date," he adds, "the passage is incessant during the summer, and continues during part of the autunn." Mr. Couch sent me a little elver, absut two inches and a half long, on the 5th. of September, and he told me that all that have passed upward from the beginning of the year are of the same size. "From microscopic examination of the ova embedded in the ovaria," the same writer observes, "I found the grains of very different size, as if the shedding them must require a long time, which is proved by the unremitting passage upwards of the young Eels for many months." The ova are scattered in the mud, and Mr. Couch concludes that the spawn for the most part is deposited in the harbour, near low-water mark, by Eels which lodge in the hollows of the stonework of the piers; but where there is no shelter, the Eels are sometimes known to enter rivulets.

That Eels breed in ponds from which there is no communication to the sea hardly admits of a doubt. The following remark of Mr. Young, published in the Angler Naturalist, clearly proves that Eels do not always deposit their spawn in tidal water:- "The rivers in Scotland," he says, "were very low in the month of July, and I watched the motions of the Eels in swarms (as I thought spawning) on the sand and gravel-banks in the river Shin. I should have mentioned this circumstance to you while here, had I not wished to be more certain; but in October last, I got a few men and made them dig out one of the gravel-banks where I had observed the Eels all together, and found it alive with young Eels, some of them scarcely hatched, at the depth of from six to fifteen inches."

Other observers have, from time to time, written in confirmation of this opinion; and I have examined a pond, the owner of which informed me that several years ago he mudded it, and then put a few Eels into it: that these Eels bred there is certain, for some years afterwards the pond was found to be pretty well stocked with Eels of different sizes; and the nature of the ground is such that it would have been impossible for any Eels-making all reasonable allowance for their powers of travelling over land-to have gained admission to it from streams which had no communication whatever with the pond itself.**

It is a most interesting spectacle to see the migration of the young Eels from the sea, and wonderful are the instinctive efforts of these little creatures to surmount obstacles that would at first view appear to present unconquerable difficulties. Mr. Anderson, upwards of a century ago, described the young Eels as ascending the upright posts and gates of the waterworks at Norwich until they came into the dam above. Ballyshannon is a very favourable place for the study of this curious subject, as we are informed by Dr. Davy, who makes the following interesting remarks on Eels ascending rocks:-

"Axrcus. This is indeed a curious sight. Here are some [Eels] wriggling up a perpendicular rock. How is it they accomplish this?

"Piscator. I believe they are able to accomplish it chiefly owing to two circumstances -their mucous glutinous surface favouring adhesion, and their form small and slender. None of these Eels, you perceive, are more than two or three inches long, and slender in proportion. Watch one that is now in progress, ascending that perpendicular rock. See how it makes its tail a support, adhering by that, whilst it projects itself upwards; and this done, now adhering by its trunk, it draws its tail after it. These are its steps, and the asperities of the surface of the rock are its stairs favouring its exertions."

Sir Humphry Davy, the celebrated author of Salmonia, and brother of the physiologist whose words I have just quoted, was a witness of the ascent of these elvers at Ballyshannon, at the end of July, 1823. He speaks of the mouth of the river under the fall being "blackened by millions of little Eels about as long as the finger, which were constantly

* I must, however, observe that I have never seen nor heard of the occurrence of elvers two or three inches long in a pond to which there was no communication to any rivers. As young elvers are diurnal in their habits, this is remarkable. 
urging their way up the moist rock by the side of the fall." "Thousands," he adds, "died, but their bodies, remaining moist, served as a ladder for others to make their way; and I saw some ascending even perpendicular stones, making their road through wet moss, or adhering to some Eels that had died in the attempt. Such is the energy of these little animals that they continue to find their way in immense numbers to Loch Erne. The same thing happens at the fall of the Bann, and Loch Neagh is thus peopled by them. Even the mighty fall of Schaffhausen does not prevent them from making their way to the Lake of Constance, where I have seen many very large Eels."

That young Eels do ascend waterfalls in the manner described by so close an observer and philosopher as Dr. John Davy cannot be doubted: it is probable, however, that their ordinary method of climbing perpendicular obstructions is by worming themselves up through the overhanging dripping moss that covers the rocks. There would be no very great difficulty in "such a getting up stairs." Mr. Couch, who has repeatedly watched the ascent up a fall of four or five feet in a stream near his own house at Polperro, has never seen a young Eel successful in its efforts to climb a moderately dry rock: "if they advance on a dry portion, their course is arrested; and after many endeavours and frequent restings they were compelled to retreat and seek a moister spot."

After the little Eels have gained the summit of the fall, they rest for a while with their heads protruded into the stream. They then urge themselves forward, taking advantage of every projecting stone or slack water, and never get carried back by the current. Falls twenty feet high are not insuperable barriers to these persevering little creatures. Although, as we have already seen, this migration of young Eels continues throughout the greater portion of the year, yet it would appear that the spring and early summer are the seasons when they ascend in the greatest numbers. In some rivers, as in the Thames and Severn, this migration is termed Eel-fare, of which the word clver is, perhaps, a corruption. They often associate in the form of long ropes in their upward migration: at other times they proceed in a promiscuous manner; every now and then diving under the sand, or resting under the shelter of a stone; always, I have observed, keeping near the sides where the stream presents fewer difficulties of ascent. Young Eels have been observed at sea four or five leagues from the land: of the myriads that ascend our rivers, few, comparatively speaking, ever arrive at Eelhood: the young tender morsels are devoured by numerous enemies, the adult Eels being amongst the number. In some Salmon rivers, Mr. Francis states that he has seen the lower pools in a perfect boil with the constant rising of the fish as the small Eels wriggle along the top of the water; so that the Salmon, if the larger Eels be destructive to their fry, exact summary vengeance. But man, as usual, is their greatest enemy. Mr. Couch told me that one of the Cornish fishermen, when at Exeter some years ago, saw "four carts loaded with little Eels, not larger than a knitting-needle, for sale, and on making inquiry was informed that the people fried them into cakes!" Elver-cakes consist of a number of these young Eels, which, after being scoured and boiled, are pressed into flat masses: they are said to present a peculiar appearance, from the number of little black eyes that bespangle them, and to be delicious food. In France these little Eels are given to the ducks and poultry, and even share the same fate as Sticlilebacks do on some parts of our coast, being carted away for manure.

Mr. Frank Buckland writes as follows in the Ficld newspaper of June 6th., I863:- "Some time since I received, through the kindness of a friend, four cakes composed entirely of young Eels. These Eels, or Eelvers, came to Langport (on the river Parrett) with the first flood-tide in March. They are about three or four inches long, and came in a continued shoal about eighteen inches wide, without cessation for some days, always against the stream, and close to the left bank. The women catch them at night by means of a canvass bag, attached to a hoop at the end of a long stick, to which a lantern is fixed. Occasionally a 
larger one is seen amongst them, of a dark colour, and almost black. They are thrown into a tub of salt, which cleanses them; they are then boiled, and pressed into cakes, which are cut into slices and fried, making the most delicious food. Sometimes they are so abundant that the people about get tired of eating them, and actually feed the pigs with them. Here there is a branch of fish-culture, which, I am sure, Mr. Francis will agree with me ought decidedly not to be neglected; and that these little Eels, which in a short time would increase their weight, and therefore their value a thousand-fold, should be looked after and not suffered to be lost to the resources of the country."

Eel-fare, once a striking and remarkable sight in the Thames, no longer exists on account of the filthy water about London, in which it has been proved that Eels cannot live any length of time. Mr. Francis has little doubt that when the Thames is once more purified "Eel-fare" will in time again recur to it.

I have occasionally taken small transparent specimens-the majority are dark olive, sometimes almost black-in which the action of the heart and gills is plainly visible. Mr. Couch thinks this transparent Eel may be a different species, and states he has never observed it in companies. According to my own experience, however, these light-coloured Eels are gregarious, and occur in company with the darker specimens. I have never succeeded in keeping young Eels of two or three inches long beyond the space of a few weeks in confinement; they are delicate little fellows, and, though they twist about with lively emotion, are doubtless not "as merry as grigs." It is impossible to obtain a better subject than a young transparent Eel for the examination of the lymphatic pulse at the end of the tail, first described by the late Dr. Marshall Hall.

Eels are pre-eminently nocturnal animals and fond of the dark. Towards evening the juvenile sniggler knows that he has the best chance of success. They always congregate at the darkest places of the stews in which they are kept, and invariably select the darkest nights for their autumnal migration to the sea. They will not start on their journey on moonlight nights; the darker and the more stormy the night, the better for a voyage. Millers are well aware of this fact, and take care to set their traps accordingly, when they are sure of a large catch. Eels are unable to endure very severe cold, unless there is plenty of mud or sand in which they can hide themselves; if kept in artificial stews without this necessary essential, they will, in frosty weather, grow quickly thin, and die in a few days. Eels generally lie buried in the mud during the winter, but, if the weather prove mild and there is abundance of rain, they will leave their holes and proceed with the floods on their migrations.* The mild winter of I86I, I was informed by a miller in my own neighbourhood, who takes many hundred-weight in the course of the twelve months, was favourable to the capture of Eels. In December of that year half a ton was taken after a flood, and continuously to March, 1862, captures were made each month. Eels will not start on their migrations unless after a flood, or at any rate without a flush of water. From November, 1862, to June, 186́3, not an Eel was taken in the traps, the weather having been remarkably dry. The instinct of the Eels doubtless causes them to wait for a flush of water to carry them down quickly to the salt water. In that curious old work by Juliana Berners, the following notice of the Eel occurs:- "The Ele is a quaysy (quasi ?) Fysshe. A ravenour and devourer of the brode of Fysshe, and the Pike also is a devourer of Fysshe. I put them bothe behinde al other for to angle. For this Ele ye shall finde an hole in the grounde of water, and it is blew and blackyshe. There put in your hooke till that it be a foote within the hole, and your bayte shall be a great anglet witch or a menowe." $\dagger$

* As a contribution to Shropshire folk-lore I may mention the following couplet which I have heard in my neighbourhood:-

"When the wallow (willow) has leaves as big as mouse's ears, Then sniggles, they'll run, they dunna care wheeres."

+ Triatyse on Fyssynge. 
As to the instinct and general intelligence of the Eel, I cannot regard M. Lacépède's notions as much exaggerated. Eels are capable of domestication, and if their affection is of the nature of cupboard love, the same is true of all other species of fish that have been tamed:- "In Otaheite," says Ellis," "Eels are fed until they attain an enormous size. These pets are kept in large holes two or three feet deep, partially filled with water. On the sides of these pits they generally remained, excepting when called by the person who fed them. I have been several times with the young chief, when he has sat down by the side of the hole, and by giving a shrill sort of whistle, has brought out an enormous Eel, which has moved about the surface of the water and eaten with confidence out of his master's hand."

We have another account of some tame Eels given by Sir IV. C. Trevelyan, of which the following is the substance:- "Some Eels had been kept for nine or ten years in a walled garden at Craigo, the seat of David Carnegie, Esq. During the cold of winter they lay torpid, unless on bright days, when they came out of their hiding-places; but they would not take food before the 26th. of April, and then they ate sparingly until the warm weather, when they became quite unsatiable. When they were first put into the pond and had no food given them they devoured one another. They generally kept quiet at the bottom of the pond, except when any of the family went to look into it, when they invariably rose to the surface; sometimes for food, and at others merely to play with the hand, or take the fingers into their mouths."

Eels have the power of living a long time out of the water, if the air is humid; this they are enabled to do on account of the smallness of the gill aperture, the membranous folds of which by closing the orifice when the Eel is out of the water prevent the desiccation of the branchix. Sometimes in their peregrinations overland they are overtaken by the rays of a warm sun, when they speedily die. They have been taken in gardens, on hooks baited for birds; and some authors have left it on record that they actually steal newly-sown peas!

Every sniggler knows that a sharp rap on the tail of an Eel is attended with satisfactory results to himself and with unpleasant consequences to the fish, which is immediately quieted by the operation. This, some say, is by reason of the injury done to the lymphatic heart or caudal pulse, as before referred to. $\dagger$ Eels, as everybody knows, are extremely tenacious of life. Yarrell states "that Eels exposed on the ground till frozen, then buried in snow, and at the end of four days put into water, and so thawed slowly, discovered gradually signs of life, and soon perfectly recovered." Such a power of endurance as this, however, must be exceptional; for, as a rule, Eels are not able to survive a hard frost unless they are embedded in their mud-holes. It may also be satisfactory to know that the stories which the shuddering cook can often tell of cut-up lengths of Eel jumping out of the "frying-pan into the fire" have in them only an appearance of horror. After the head is severed from the body, it is clear that there can be no sense of feeling properly so called; the life-like signs exhibited are accounted for by the high degree of irritability of the muscular fibre. Very curious stories have been told of the power of the Eel' to survive under peculiar conditions. $\neq$

Eels have many enemies: otters, polecats, rats, various water-birds, such as herons and swans, occasionally make them their prey, not to mention the rapacious Pike, the Salmon, and the Slob Trout, which are all very fond of elvers. The rats and polecats make their attacks in the winter when the Eels are dormant. $\$$

$$
\text { * Pul'nesian Researches, ii. p. } 286 .
$$

+ But is it not more proluable that the effect is due to concussion of the spine? The stoppage of the lymphatic heart could scarcely be followed by so immediate a result.

† Gesner says - "Phalacrocorax anguillas integras vorat, quod Anglus quidam nobis retulit; ille mox per intestina elapsx, denuo devorantur, idque vel novies aliquanclo repetitur, prius quam debilitata tandem retineatur."-De Aquat., 1) +5 , D. And see Prose Haliutics, p. 3 S9. 
In a letter in the Zoologist for 1846 upon this subject, Mr. Banister says:- "We have polecats abundant in Pilling during the whole year; and in the winter season, when the water in the ditches in the main drains is chiefly congealed, and more especially when the ice is covered with snow, the footprints of the polecat may be traced on the ice, and the most indubitable evidence is thus afforded of its predilection for fish. Under such circumstances I have repeatedly ascertained that this animal is a most expert fisherman, for in severe and long-continued frosts many Eels ascend our open drains, and as these watercourses are most slightly frozen over near the springs, the polecats, either by instinct or experience, discover the retreat of the Eels. In tracing the footprints of the polecat it will soon be ascertained that he halts at every hole or opening he meets with in the ice, and at once commences fishing, by introducing a fore-foot into the water, and, no doubt, groping all around under the ice as far as he can reach in search of such Eels as may have come to the aperture for air. That he uses his fore-paws in this manner is distinctly proved by his dirty footprints afterwards in the snow. It is also an admitted fact in the natural history of the Eel, that it cannot exist without air. The polecats then, aware, either from instinct or habit, of this propensity of Eels to assemble round any aperture in the ice for the benefit of the air, invariably search for them at every opening they meet with; and in tracing their footprints in the snow, as above described, it will frequently be discovered that Eels have been dragged from under the ice by these wily fishermen, and either devoured on the surface or carried to their dens to satisfy their hunger at some future opportunity."

Every naturalist has observed the peculiar denticulation on the inside of the middle claw of the common heron: is it probable, as Lacépède observes, that the bird drives this claw into the body of the Eel, and so renders ineffectual all its efforts to slip from its grasp? The heron, doubtless, occasionally finds a large Eel an "awkward customer;" and he frequently has to come out of the water on to the land, so as to be able to deal his slippery friend stronger and better directed blows. Yarrell relates, and gives a spirited vignette of the circumstance, that a heron had once struck his sharp beak through the head of an Eel, piercing both eyes, and that the Eel-no doubt remembering that one good turn deserves another-had coiled itself so tightly round the neck of the heron as to stop the bird's respiration; both were dead.

That Eels are not devoid of sagacity is proved by many well-attested anecdotes: they are said to form themselves into companies for hunting, and by partly encircling a shoal of small fish, drive them to the shore, where they are more readily caught and devoured. Mr. Jesse states that he has observed this fact in the canal in Hampton Court Park. Eels are not particular in their choice of food: young water-fowl, fish of all kinds, worms, spawn, insects, crustacea, \&c., form their staple articles of diet. They appear, however, to vary their dinners with occasional nibbles at fresh-water plants. In warm weather they are often to be seen coiled round an aquatic plant in a vertical position; for what purpose they do this I have been unable to discover. In the winter time Eels are often found knotted together in large masses. This fact was known to Pliny. Is it probable that they congregate for the sake of ensuring warmth?**

Eels are of great commercial value; and there seems to be no reason why Eel-culture, if attempted in the British Isles, should not be attencled with satisfactory pecuniary results. Incalculable numbers are annually destroyed, as they ascend our rivers: it is a pity these young elvers are not protected. Of course, in rivers which are favourable to the increase of Salmon and Trout the presence of large quantities of devouring Eels is anything but desirable; but their multiplication in our sluggish rivers, which contain either such fish as are able to take care of themselves or such as are, comparatively speaking, worthless, is a matter worth consideration. 
The London market is principally supplied with Eels from Holland, a country where they abound. According to an estimate made by Mr. Mayhew, no fewer than nine millions seven hundred and ninety-seven thousand seven hundred and sixty Eels are annually sold in Billingsgate market, amounting to a weight of one million five hundred and five thousand two hundred and eighty pounds, one fourth of which is sold by the costermongers. Mr. Mayhew thus graphically describes a visit to the Dutch Eel-boats with their bulging polished oak sides:- "I went to the shore where the watermen ply for passengers to the Eel-boats; they were surrounded by skiffs that ply from the Surrey and Middlesex shores and wait yhilst the fares buy their fish. The holds of these Eel-boats are fitted up with long tanks of muddy water, and the heads of the Eels are seen breathing on the surface, a thick brown bubble rising slowly and floating to the sides. Wooden sabots and large porcelain pipes are ranged round the ledges, and men in tall fur caps, with high cheek bones and rings in their ears, walk the decks. At the stern of one boat was moored a coffin-shaped barge pierced with holes, and hanging in the water were baskets shaped like olive-jars, both to keep the stock of fish alive and fresh. In the centre of the boat stood the scales, a tall, heavy apparatus, one side fitted up with the conical net-bag to hold the Eels, and the other with the weights, and pieces of stone to make up for the extra draught of the water hanging about the fish. When a skiff-load of purchasers arrives, the master Dutchman takes his hands from his pockets, lays down his pipe, and seizing a sort of long-handled landing-net, scoops from the tank a lot of Eels. The purchasers examine them, and try to beat down the price. "You calls them Eels, do you?' said a man with his bag ready opened. 'Yeas,' answered the Dutchman, without any show of indignation. 'Certainly there is a few among them,' continued the customer; and after a little more of this kind of chaffering the bargain is struck."

But although London is chiefly supplied with Eels from Holland, we must not suppose there are no valuable Eeleries in the British Isles. There is a large Eel-fishery at Toome, on the lower Bann, where from fifty to sixty tons of Eels are annually caught in the migrating season. "As many as seventy thousand Eels," we are told, have been taken at this place in one night, all of the Sharp-nosed species, with the slight exception of, perhaps, a dozen Broad-noses, that have been accidently mixed up with the shoal. "On one night in I842," observes Mr. Pinkerton, "when I visited the Toome fishery, there were caught in round numbers, eleven thousand Eels. Now, as the persons who purchase the produce of a season's fishing by contract expressly stipulate that they will not take a single Broad-nosed Eel, every Eel-with a dexterity of eye and hand worthy of a Robin or a Frikel, and only acquired by long practice-is carefully counted, and all Broad-nosed ones thrown aside. And on this occasion there were only three Broad-noses in the whole number." $\dagger$

There is also an extensive Eel-fishery on the Erne. That Eels were formerly in high repute in England seems clear from the fact that certain places take their names from them. Ely, according to one derivation, has its name from the Eel, the rents being formerly paid in this fish; the lords of the manors, it is said, being annually entitled to more than one hundred thousand. Elmore and Ellesmere are said to have the same derivation.

As to the question of the wholesomeness of Eel's flesh, there can be no doubt that, owing to the large amount of rich fatty matter which it contains, it is not a diet suited to the stomach of a man of weak digestion, unless eaten in very small quantities. I confine this observation to the flesh of a clean-fed Common Eel; drain-fed individuals, as well as the offensive Broad-nose, are likely to agree with none but very coarse feeders indeed. It was not the fault of the Lampreys that King Henry diec, it was his own fault for eating too much. And although I cannot acquiesce in old Galen's expostulation with the gods for giving

$$
\text { * London Labour and London Poor, vol. i. p. } 66 .
$$

f When I visited Toome in July, 1878 , the Fel fishery was just commencing; and I saw great numbers packed in boxes which had been caught during the night in the large purse-shaped nets set across the strea:n of the Bann. 
Eẹ̣s so delicious a taste and so malignant and dangerous an operation, I must not forget the remark of Fuller, "Grant them never so good, excess is a venomous sting in the most wholesome flesh, fish and fowl." However, be this as it may, "the proof of the pudding is in the eating;" and it is certain that hot Eels are a most wholesome and nutritive food to the London poor. "Hot Eels" form an important street luxury; and Mr. Mayhew* has given a minute and interesting account of the trade.

The skin of the Eel is remarkably tough. In the times of the ancient Romans it was used to whip naughty boys, who were thus exempt from the infliction of any pecuniary fine, having been mulcted, not in coin, but in their own skin! $\dagger$ A similar use of Eel-skin prevailed in the sixteenth century, as appears from the following quotation from Rabelais:- "Whereupon his master gave him such a sound lash with an Eel-skin, that his"own skin would have been worth nothing to make bag-pipe bags of." $\ddagger$

Eel-skin is the object of a small trade in some cities. In Tartary it is used, after having being oiled, as a substitute for window-glass. It is supposed by the poor to be a good remedy for cramp or rheumatism, and 1 have often spoken with poor persons who attach great virtue to the skin of the Eel. "I amner quite sure, maister," said an old man to me once, "whether it be a sartain cure for the rheumatis; but for cromp, I knows there be nothing loike it."

Eel-skin must have inflicted severe punishment on boy-skin, not only on account of its toughness, but from the presence of innumerable numbers of concretions of carbonate of lime. A portion of Eel-skin mounted in Canada balsam, and viewed under the polariscope, is a beautiful object for the microscope. Eels vary much in colour; the silver Eel is generally the most highly prized. Silver Eels are certainly very delicious, but, according to my own experience, I find the green-bellied Eels equally good; nor have I any fault to find with yellow-bellied specimens. Prejudice, of course, is against both of these colours, but I can confidently recommend any Common Eel if he is taken out of clear water. I have seen a cream-coloured Broad-nose, which was doubtless an albino, and owed its whiteness to the absence of pigment cells. Sometimes piebald Eels have been met with, and a correspondent in the Field newspaper mentions his once having received an Eel of a rich golden colour like Gold-fish.

It is not common in this country to meet with an Eel above the weight of five pounds, though there are well authenticated instances of Eels attaining the weight of fifteen, or even twenty pounds. $\S$

* London Labour and London Poor, vol. i. p. 160.

† Pliny, N. H. ix. 23.

$\ddagger$ Book ii. c. 30, translated by Mr. Ozell. Lond. 1737. The term anguilla was in later times applied to a whip' made of leather thongs, which was used to flog boys. See Isidore's glosses quoted by Du Cange in his Latin Glossary. "Anguilla est quâ coercendi in Scholis pueri, quæ vuigo Scutica dicitur."

$\S$ The substance of the above remarks on Eels was written by me a few years ago, and appeared in a number of the Quarterly Review. I have Mr. Nurray's kind permission to make use of that article. 




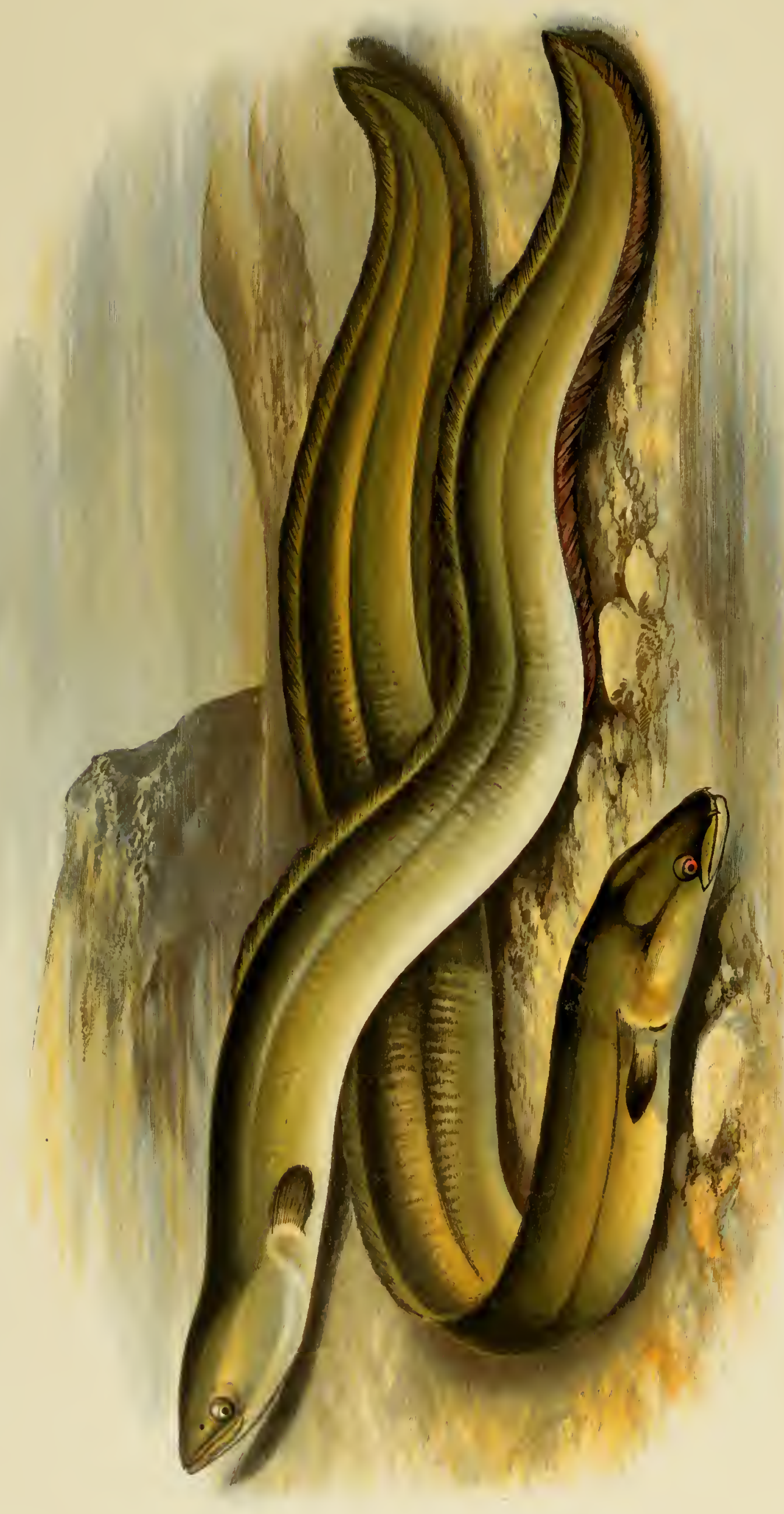

미

a 


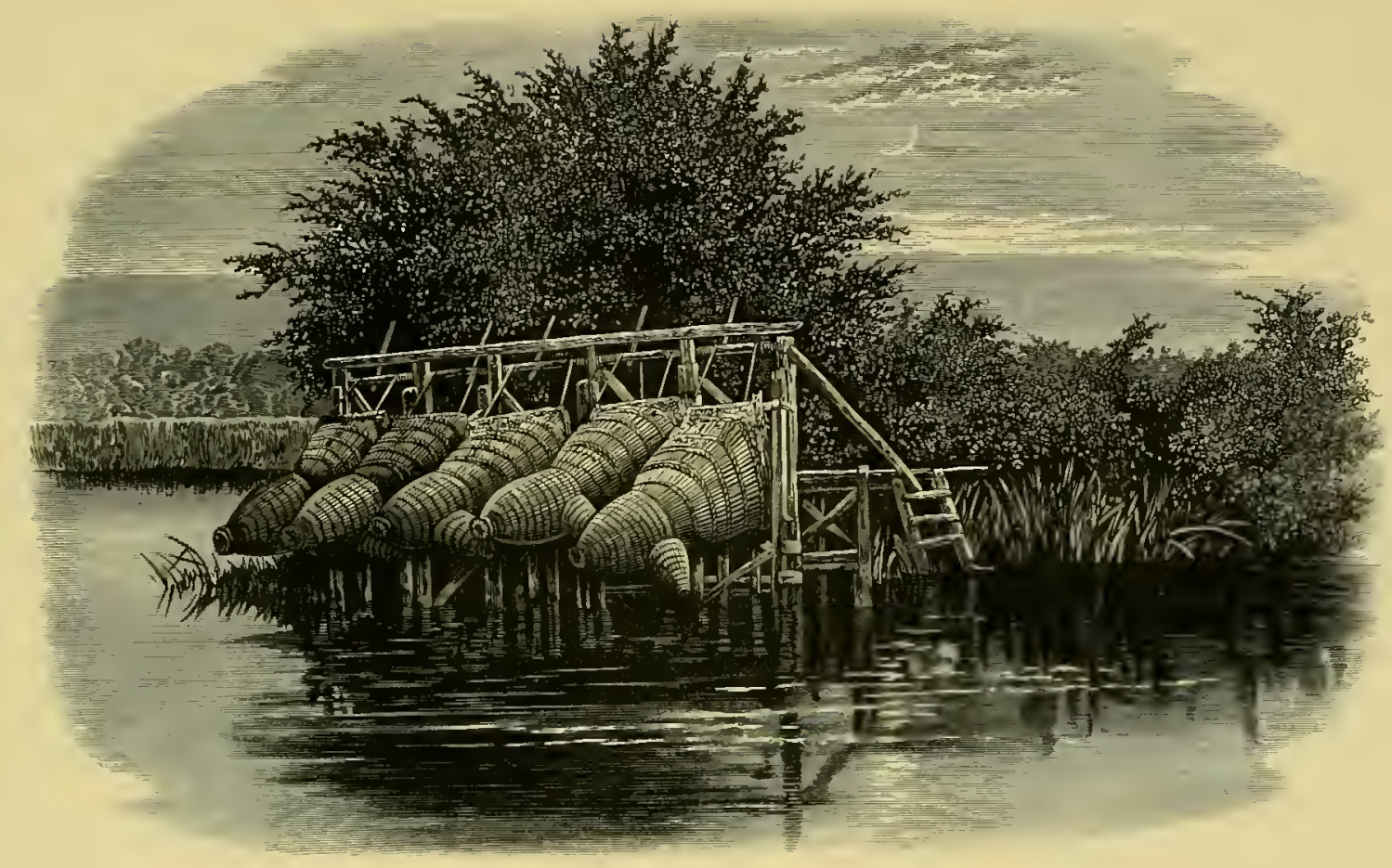

Eel Bucks on the Thames.

Orler 11.

PIISOSTOII.
Family

MUR EIIDAE.

Group-Anguillina.

\section{SHARP-NOSED E EL.}

\section{(.4nguilla vulgaris.)}

Anguilla omnium autorum, An Ed,

.Murcenir uni:olor, mavilla in firione longiore,

Mlurcena anguilla,

Common $E_{e l}$,

Anguillu i'ulgaris,

Anguilla acuirmstris and medioroshis,

Anguilla hitionica,
Wıllughby, Hist. Pisc. p. ı og, tab. G. 5 .

Artedi, Gen. Pisc. p. 24, No. I.

Lin., Sys. Nat. i. p. 426 ; Bloch, Fisch. Deutschl. iii. p. 4 , taf. 73 . Pennant, Brit. Zool. iii. p. I 91.

Flear., Brit. Anim. p. ig9; Sinbold, Süsserwasserf. p. 342 ; Günther's Cat. viii. p. 28 .

Yirrell, Brit. Fish. ii. p. 381 and p. 399 ; Couch, Fish. Brit. Isl. iv. p. 326, pl. $23+$ and 235 .

Covch, p. 328 , pl. 235 .

Charaters of the Gimes ANGuilda. - "Small scales are imbedded in the skin. Upper jaw not projecting beyond the lower. Teeth small, forming bands. Gill openings narrow, at the base of the pectoral fins. The dorsal fin commences at a considerable distance from the occiput. Cosmopolitan, but not extending into the arctic regions."-GüNTHER

1 S I think that I have already treated of most that can be said of interest in the natural history of the Eel, it will not be necessary for me to do more than to describe the species of Eels which occur in this country. There can be no doubt that Eels, like other fish, are 
subject to vary, not only in colour but in slight structural peculiarities. Any one who has seen the great numbers caught in the Eel traps, as, for instance, at Toome Bridge, County Antrim, and has had opportunities of noticing them, must have observed considerable difference amongst individuals in the form of the snout; in very many cases the snout is much pointed, in others less pointed, and not unfrequently the nose is almost obtuse. Hence some naturalists have regarded individuals with differently formed snouts as forming distinct species; which have been described as "Sharp-nosed Eels" (A. acutirostris), "Middle-nosed Eels" ( $A$. mediorostris), and "Blunt-nosed Eels" (A. latirostris). This difference in the form of the nose, when existing as the only characteristic, is not regarded by the greatest authority on such matters, Dr. Günther, as being sufficient to constitute specific difference. It would appear, however, that there are two species of Eel, the $A$. vulgaris with its nasal varieties of form, and the $A$. latirostris which besides being generally possessed of a very obtuse snout, has other peculiarities which would entitle it to specific distinction. To these peculiarities as mentioned by Günther, I think I may add from personal experience that one of a disagreeable flavour. The varieties of the Common Eel are always, when taken from good waters, most delicious; and no difference in flavour can be detected from the Sharp-nosed variety, the Middle-nosed variety, and the Blunt-nosed variety of $A$. vulgaris when taken out 'of the same water; but my experience of $A$. latirostris would lead me to discard it altogether as food. In a large reservoir of excellent water which supplies a canal, at Knighton in Shropshire, there exist the varieties of the Common Eel and the Broad-nosed species. I have seen many taken on Eel-lines and trimmers of both species, and I have always found the flavour of the Broadnosed species very bad eating.

The following is Dr. Günther's description of Anguilla vulgaris; the essential distinctive characters between this species and the other are printed in italics:- "The length of the head is contained once and one half, or once and a third in the distance of the gill opening from the origin of the dorsal fin, and twice and one third, or twice and two thirds in its distance from the vent. Distance between the commencements of the dorsal and anal fins as long as or somewhat longer than the head. Lips narrow: lower jaw prominent. Angle of the mouth below the eye, which is rather small or of moderate size, much shorter than the snout. Maxillary teeth equal and small. Tail considerably longer than the body."

Ordir $I V$ :

PHFSOSTOMI.

\section{Family}

MUUR ENID EE.

Grouf-Anguillina.

\title{
雷ROAD-NOSED 践EL
}

\author{
(Anguilla latirostris.)
}

Grigs or Gluts, Anguilla latirostris,
Pennant, Brit. Zool. iii. p. I94, ed. 1812.

Yarrell, ii. p. 396; Jenyns' Man. p. 47 ; Günther's Cat. viii. p. 32

DENNANT speaking of this Eel says, "Besides these" (Eels which vary in colour) "there is another variety of this fish, known in the Thames by the name of grigs, and about Oxford by that of grigs or gluts. They are scarcely ever seen near Oxford in the winter, but 
appear in spring, and bite readily at the hook, which Common Eels in that neighbourhood will not. They have a large head, a blunter nose, thicker skin, and are less fat than the common sort; neither are they so much esteemed; nor do they often exceed three or four pounds in weight." The term grig is also applied to any kind of Eel, especially to those individuals of small growth.

I have taken this Broad-nosed species, in company with Mr. Masefield, of Ellerton Hall, on several occasions, in Knighton Reservoir. Our plan is to set trimmers in the different parts of the pool baited with small Roach or other bright coloured fish, the bait being near the bottom; the bull-headed appearance and great thick lips, generally speaking, indicate the species. As already stated, as food it may be discarded; at least to the palate its flesh is very disappointing when one thinks of the deliciousness of the "white armed goddess," the Common Eel.

Dr. Günther describes this species as follows:- "The length of the head is contained once and a half, or once and three fourths in the distance of the gill opening from the origin of the dorsal fin, and twice and a half in its distance from the vent. Distance betwecn the commenconcuts of the dorsal and anal fins shorter than the head. Lifs broad and flcshy, lower jaw prominent. Angle of the mouth below the hind margin of the eye, which is rather small, much shorter than the snout. Tail considerably longer than the body. Mandibulary teeth in a single band, without longitudinal groove."

This species occurs in Europe, the Nile, China, New Zealand, and the West Indies; it is the only form of all the varieties of the Common Eel, which is regarded by Günther as entitled to specific rank. "The width and length of the snout cannot be taken as a distinctive character, as there are found all intermediate forms between the extremes. I am more inclined to consider the situation of the origin of the dorsal fin, and the development of the lips, to indicate a distinct species."

Some years ago when I had been for some time occupied in dissecting a number of Common Eels and a couple of Congers, I observed the invariable presence of two sub-triangular openings in the fleshy portion of the head, just at its juncture with the spinal column. My first impression with regard to the use of these orifices was that they were connected with the auditory organs, and that they probably led to the vestibular cavity. Although so far, I believe, as has hitherto been observed, the existence of external auditory organs in the whole class of fishes is very exceptional-the Skates amongst the cartilaginous order, and a few of the members belonging to the Gadide and Clupeida amongst the osseous order alone possessing them-still I thought it not improbable that the Eel, which is commonly supposed to hear well, and which is occasionally an overland traveller, might prove another exception to the general rule. I may observe that Mr. Cholmondeley Pennell, in his work The Anoler Naturalist (p. 397), asserts the presence of an "ear or auditory aperture" amongst the various mucus pores about the head, but from the most minute examination of a large number of Eels' heads I can confidently affirm that no such external auditory aperture exists. I have, therefore, no doubt that Mr. Pennell must have mistaken two of the mucus pores for ears.

Upon my inserting a bristle in each of these orifices, and on clearing away the flesh from the head, I found that each bristle traversed a closed-in duct or tube in the cranium, and came out just above the orbital bone (see fig. I). On making a vertical section of the skull, and examining with great care the vestibular sacs, I became convinced that the tubular ducts had no connection with them nor with the auditory nerve (fig. 4). Each of these tubes, which in the Common Eel is just wide enough to admit a fine piece of silk-gut, terminates in a membranous fold or hollow in the subcutaneous tissue just above the eye (fig. 5), and contains a certain quantity of thin fluid or lymph, which, by the way, bears no resemblance to mucus. Are these cavities reservoirs for the supply of fluid to lubricate the surface, and may we conjecture that the lymph is drawn up the tubular ducts by capillary attraction? 
There is?little reason to doubt that the cranial ducts are connected with the so-called "mucus system," which is very complicated in the Eel tribe, but in what manner they are so I have hitherto been unable to satisfy myself, and leave the determination of the question to the investigation of more experienced anatomists.
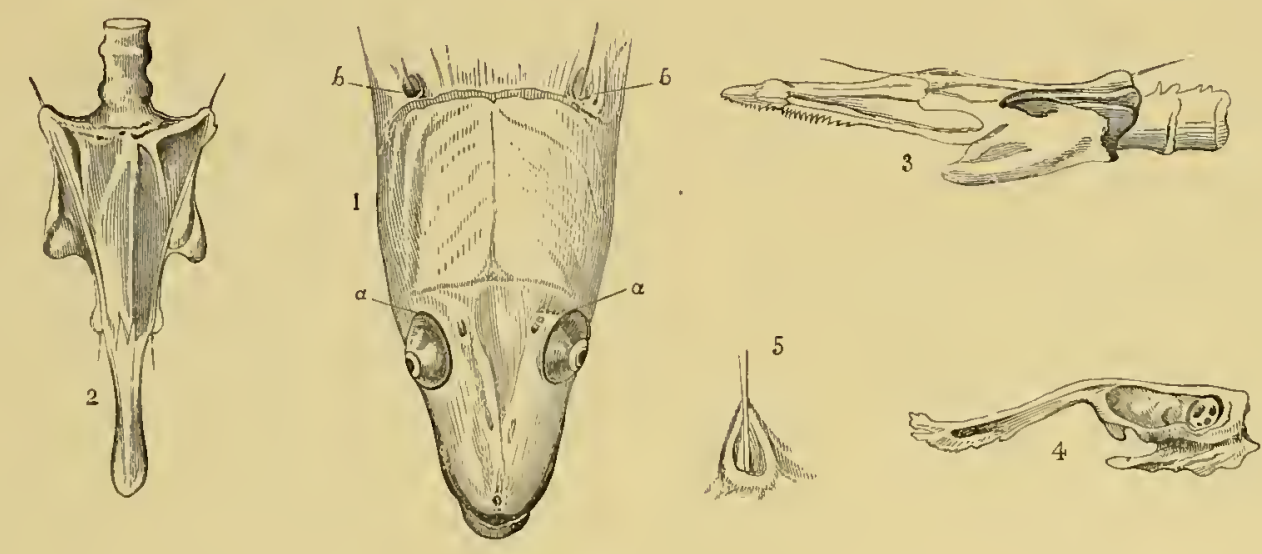

Fig, 1,-Head of A mulgaris, showine the orifices of the canals, a, Anterior orifice, $b$, posterior ditto.

Fig. 2.-The same, with the soft parts removed, and with a bristle inserted into each canal. Fig. 3.-Side view of same.

Fig. 4.- Vertical section of cranium of A. vulguris. Fig. 5,-Nembranous fold or bollow in which the canal terminates. 


\section{AMPREYS.}

7 HE Lampreys, Lamperns, or "nine-holes," as in some places they are termed, belong to 1 a very remarkable family of fishes. From their habit of attaching themselves to stones or other submerged bodies, they have received the name of Potromyzontidce, which in Greek signifies "stone-suckers," a term aptly proposed by Artedi. The body is worm-like, cylindrical, and limbless; the skeleton is imperfectly developed, being cartilaginous; the notochord is persistent through life; there are no ribs, and no real jaws; the skin is without scales and lubricous; the fin-fold of the tail is destitute of fin rays; the gills have no branchial arches, and are formed like little pockets or pouches. The mouth is of very peculiar

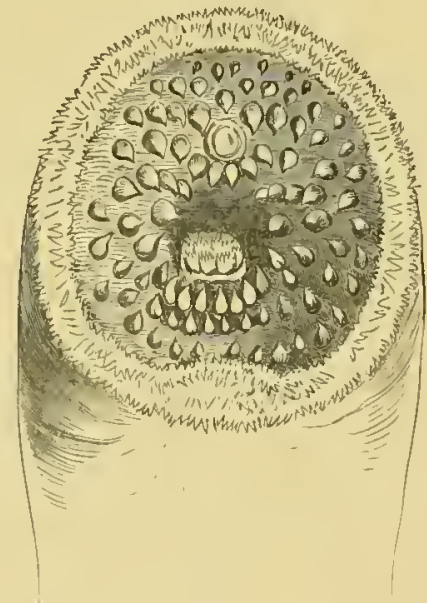

structure, of circular form in the adult fish, suctorial, and armed with either simple or many-pointed teeth of horny consistency. The nasal cavities do not communicate with the throat; the gill-pouches, with their external holes or openings, are seven in number, situated on each side of the neck, so that the popular name of "nine-holes" is an erroneous one. The respiratory apparatus is very peculiar; fishes as a rule admit water through the mouth and emit it through the branchial slit, or gill opening; the Lampreys fix themselves to submerged bodies by their suctorial mouth, so that when in such a position it is obvious that no water can be admitted through the mouth. How then is the water admitted so as to oxygenate the blood of the gill-pouches? The water is alternately received and expelled 
by the external openings of the gill-sacs. "If a Lamprey, while so attached to the side of a vessel, be held with one series of apertures out of the water, the respiratory currents are seen to enter by the submerged orifices, and after traversing the corresponding sacs and the pharynx, to pass through the opposite branchix, and to be forcibly ejected therefrom by the exposed orifices...... The cyclostomous fishes thus present an obvious affinity to the Ccphalapoda, inasmuch as the branchial currents are independent of the parts concerned in deglutition." (Prof. Owen, Catal. Phys. Scr. Muts. R.C.S., ii. p. 8o.) The heart has an auricle and a ventricle, but no bulbus arteriosus. The alimentary canal is straight, simple, and without cæcal appendages; there is no swim-bladder. Probably all the species go through a metamorphosis.

The Pitromyzontida are found in the fresh waters and around the sea-coasts of the temperate regions of both hemispheres. By means of their suctorial mouths they attach themselves to other fishes, and scrape off their flesh by their rasp-like teeth. The food consists also of worms and insect larva. The British species are three in number, and are all of them excellent food; but owing to the small size of one of the species, only two are of any commercial value. 



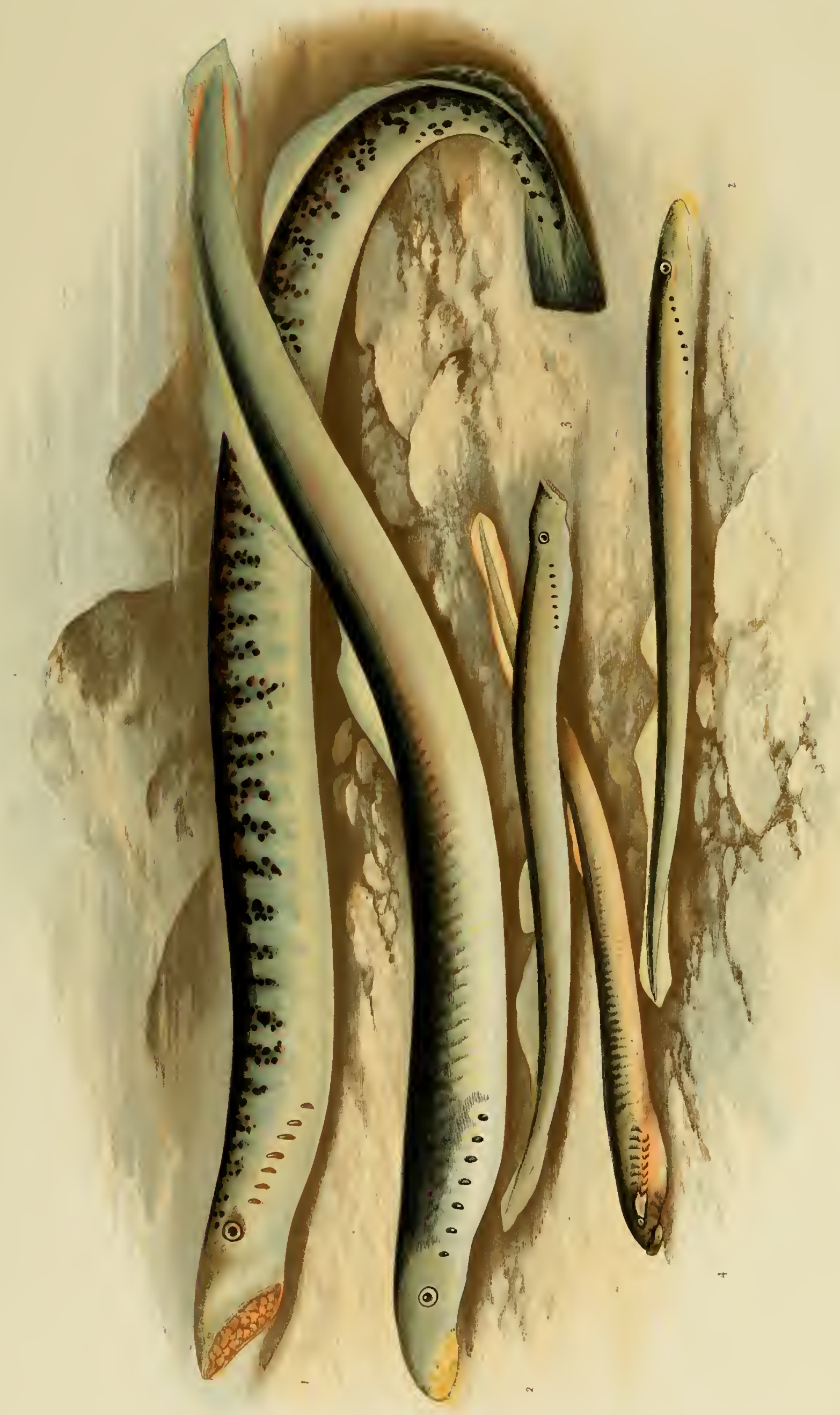

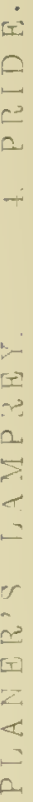




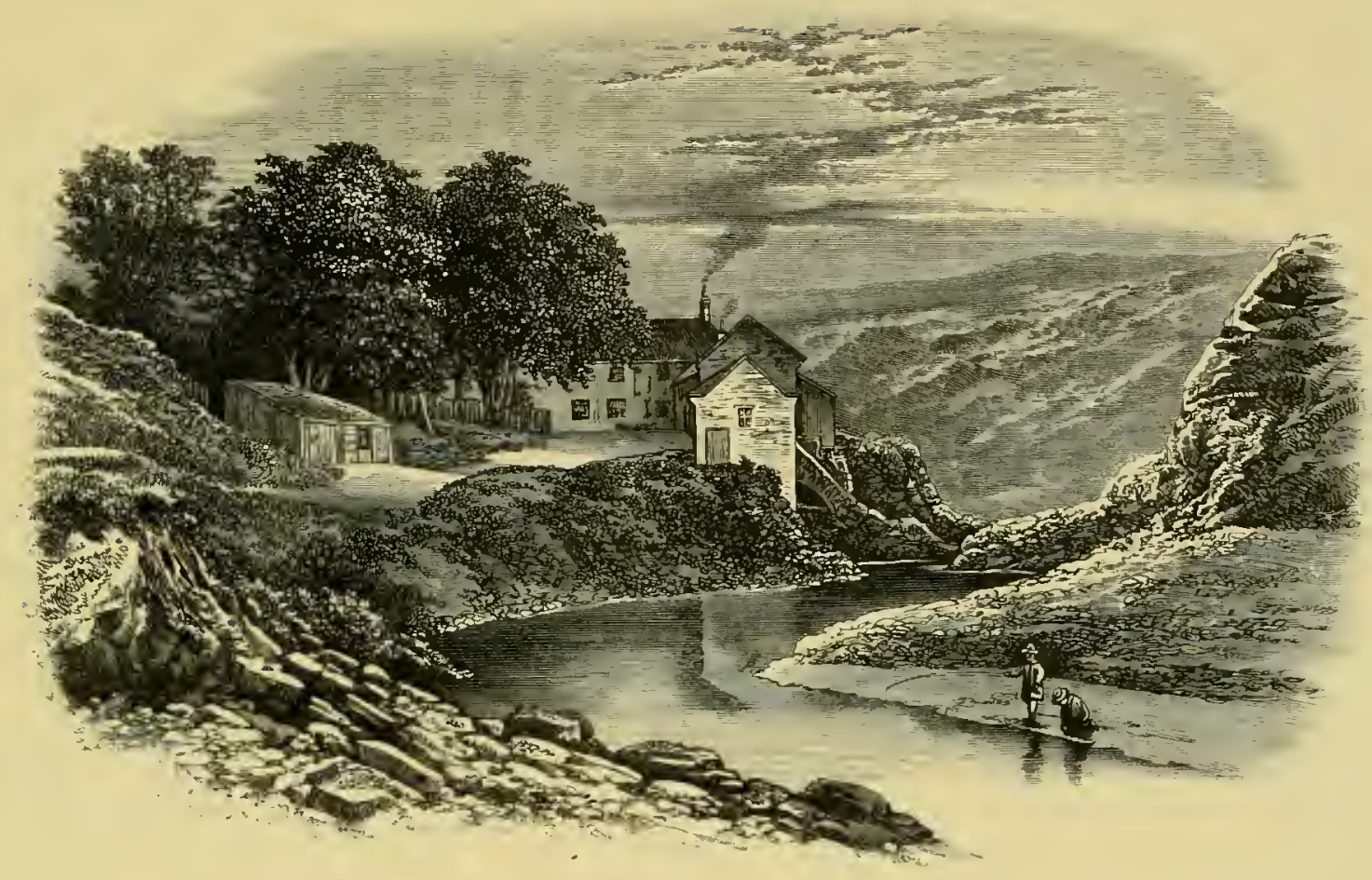

At Scalby Mill, near Scarborough,

Sub-class

CYCLOSTOAАTA.

CYCLOSTONA $T A$.

SEA 䇫AMPREY.

\section{(Petromyzon marinus.)}

\author{
Lampetra major, \\ Mustela sive Lampetra, \\ A Lamprey or Lamprey Eel, \\ Petromyzon maculosus, ordinibus dentium \\ circiter viginti, \\ Petromy'zon marimus,
}

Sea Lampriy,
AlDRov, iv. cap. I 3 .

Bellow, De Aquatil. p. 76 .

Willeghey, Hist. Pisc. p. Io5.

Artedi, Spec. Pisc. p. 90, No. 2.

Lin., Sys Nat. i. 1) 394; Donovan, Brit. Fish. iv. pl. 8I; Fiem., Brit. An. p. I63; YARRell, ii. p. 598; Siebold, Süsserwasserf. p. 368: GüNTHER's Cat. viii. p. 501.

Pennant, Brit. Zool. iii. p. 102 , ed. 1812 ; Couch, Fish. Brit. Isl. iv. p. 385, pl. 247 , fig. 1 .

Characters of the Genus Perrourzas. - "Dorsal fins two, the posterior continuous with the caudal. The maxillary dentition consists of two teeth placed close together, or of a transverse bicuspid ridge; lingual teeth serrated. Coasts and fresh waters of the northern hemisphere."-GünTHER.

THE Sea Lamprey, which from its marbled appearance was called Petromyzon maculosus 1 by Artedi, is an inhabitant of the rivers and coasts of Europe, North America, and Vest Africa, and specimens from all these parts are now in the British Museum. It occurs in 
Scotland and Ireland. The Severn, in the neighbourhood of Gloucester and Worcester, has long been celebrated for this and another species, viz. the $P$. fuviatilis, which is considerably smaller than the P. marimus. In the neighbourhood of Worcester the term Lamprey is usually employed to designate the $P$. marimus, while the $P$. fuviatilis is known by the name of Lampern.

The species now under consideration is the one which brought King Henry the First to an untimely end; that monarch, it is said, having made a too full repast on this fish. Pennant states that it was an old custom for the city of Gloucester to present the kings with a Lamprey-pie, covered with a large raised crust. As the gift was made at Christmas, the corporation had great difficulty in procuring fresh Lampreys at that time, though they gave a guinea apiece for them so early in the season. At present, as I learned when I was at Worcester last October, the Sea Lamprey is taken only in the spring, when it is ascending the river from the sea for the purpose of spawning. They are caught both in nets and in large wicker weels. Pennant says that notwithstanding the accident which befel Henry I., Lampreys continued in high esteem. "Henry IV. granted protection to such ships as brought over Lampreys for the table of his royal consort. His successor issued out a warrant to Willian of Nantes, for supplying him and his army with Lampreys, wheresoever they happened to march."

The circular suctorial mouth of the Lamprey is made use of, at spawning time, for the purpose of forming furrows or holes in the gravel, by removing stones from the place where the fish wishes to deposit its spawn. Spealing of the Lampreys of Scotland, which make their appearance in the rivers there later than in southern rivers, Sir William Jardine says"They ascend our rivers to breed about the end of June, and remain until the beginning of August. They are not furnished with any elongation of the jaw, to form the receiving furrows at this important season; but the want is supplied by their sucker-like mouth, by which they individually remove each stone. Their power is immense. Stones of a very large size are transported, and a large furrow is soon formed. The $P$. marims remain in pairs; two on each spawning place; and while thus employed, they retain themselves affixed by the mouth to a large stone." From enquiries I made when at Worcester, the Lamprey spawning-bed consists of either furrows or holes made in the gravel in May; ${ }^{*}$ the fish remain in the river a very short time after spawning; they seem much weakened after that process, and are quickly washed down by the river into the sea, where no doubt they recruit their exhausted condition.

I have never tasted the Sea Lamprey, but if the quality of its flesh is at all similar to that of the River Lampern, it must be most delicious eating. $\dagger$ According to Parnell the fishermen in the Forth, above Alloa, when they accidentally take Lampreys in their nets, "invariably return them again to the water, having a prejudice against them." Consequently they are never under any circumstances seen in the Edinburgh markets. The snake-like form and unpleasant look of the fish doubtless accounts for Scotch antipathy, as I have alluded to when speaking of Eels. Mr. Couch also, in his Fauna of Comwall, says of this species that it is common, but rarcly used as food.

The words Lamprey and Lampern, from lambere, "to lick," and petra, "a stone," answers to the Greek pitromyzon already explained.

The characters of this species are thus given by Günther. "Two pointed maxillary teeth close together; mandibulatory tooth single, crescent shaped, with from seven to nine cusps. 'Two pairs of lunate, pectinate lingual teeth; the teeth of the anterior pair confluent. Suctorial

* Fishing for the Sea Lamprey in the Severn near Worcester begins in February and lasts till May.

† The mode of preparing the Lamprey, or Eel Lamprey as it is also called, at Worcester before cooking is by putting the fish in boiling water and then scraping them with a knife; this is clone to get rid of their abundant mucus; they are then placed in cold water, and are ready for stewing or potting. 
disc with numerous conical teeth, arranged in oblique series, those nearest to the buccal cavity being largest and partly bicuspid. First dorsal fin rather widely separated from the second. The distance of the last gill-opening from the extremity of the snout is one fifth, or in small individuals, one fourth of the total length. Body marbled with black."
Sub-class
CYCLOSTOMATA
Family
PETROMYZONTIDA:

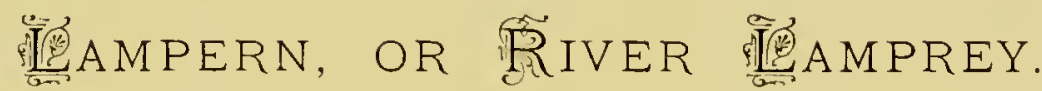

\author{
(Petromyzon fluviatilis.)
}

\author{
Lampetre medium senus, \\ Lampetra parza el furiatilis, \\ Pitromyzon, \\ Pitromizon funtiatilis, \\ Lesser Lamprey, \\ Lampern, Silver Lamprey, \\ Petromy'ron pricka,
}

\author{
Willughry, Hist. Pisc. p. 106, tab. G. 3, fig. 2. \\ Rond., De Pisc. Fluv. p. 202. \\ Artein, Spec. Pisc. p. 89, No. I. \\ L.in., Sy's. Nat. i. p. 394 ; Donovan, Brit. Fish. iii. pl. 54 ; Yarrell, ii. \\ p. 6o.7; Siebold, Süsserwasserf. p. 372 ; Günther's Cat. viii. p. 502. \\ Pennant, Brit. Zool. iii. p. 106 , pl. x. fig. 2, ed. 1812. \\ Cotch, Fish. Brit. Isl. ir. p. 395-400, pl. 247 , figs. 2 \& 3. \\ L.ACÉP., i. p. 18.
}

$\mathrm{T}^{\mathrm{l}}$

HE River Lamprey, or, to distinguish it from the Sea Lamprey, the Lampern, as it is more generally called, is a much smaller species than that already described. It occurs in the rivers and on the coasts of Europe, North America, and Japan, and has therefore a very wide geographical distribution. In this country it is abundant in many of the rivers of England, Scotland, and Ireland. It is probable that this species is not so generally migratory in its habits as $P$. marinus, and that it is sometimes, and perhaps frequently, a permanent inhabitant of fresh water. Yarrell's opinion is that it generally remains all the year in fresh water. "In the Thames," he says, "l am certain it is to be obtained every month in the year." From enquiries I made at Worcester, Lampern fishing begins, in the Severn and Teme, about the ist. of October, and lasts till February or March; the fish then disappear. Lacépède states that the $P$. fluviatilis is an inhabitant rather of lakes than of rivers, that it ascends the latter only when about to spawn, that is to say, in the spring. Couch is, I think, correct when he says that some individuals have been found in the open sea, "to which it is probable they do not proceed at all seasons, as if in regular migration, and where they do not continue long."

In Pennant's time Lamperns were found in the Thames, Severn, and Dee; they were potted with the larger species, being preferred by some people to it, as being milder in flavour. He states that vast quantities were taken about Mortlake and sold to the Dutch as bait for their cod-fishing. "Above four hundred and fifty thousand have been sold in a season, at forty shillings a thousand." Owing to the present impure condition of the Thames, the numbers of these fish, I believe, have fallen off very considerably. The head-quarters for Lampern fishing is on the Severn, near Worcester and Gloucester, where great numbers are caught 
in wicker weels from October to March or April, about which time they spawn; nothing more is seen of them after that time. In order to get rid of the mucus the fish are placed in hot water in a vessel and whisked about with a bunch of straw; they are then put in cold water for a short time, and are ready for stewing or potting, under either of which happy conditions they are most delicious food, even rivalling the white-fleshed Eel in richness of flavour. The ordinary price for fresh Lamperns is about ten shillings a hundred.

The River Lampern lives on the larvæ of insects, worms, and according to Bloch the flesh of dead fish. The ordinary adult size of the Lampern is about a foot in length; when first out of the water the back and sides are of a pretty uniform brown, with a tinge of olive or green on the upper part of the head and back; the belly is pure white. "The maxillary tooth is single, forming a transverse ridge with a cusp at each end; mandibulary tooth single, crescent-shaped, with about seven cusps. Tongue with a broad, transverse, trenchant tooth, which is provided with a median cusp. Two or three bi- or tri-cuspid teeth on each side of the gullet; the other teeth of the suctorial disc are small and not numerous. First dorsal fin separated from the second by an interspace. Colouration immaculate; sides silvery."

\title{
SMALL I P.PANER'S IEAMPREY.
}

\author{
(Petromyzon branchialis.)
}

(1.) Larval Ford.

Lampetra ceca seu oculis carens, Einblinder, Neunogen, Petromyzon corpore anmuloso, Petromyzon branchialis,

Pride Lamprey', Ammocetes branchialis,

Mud Lamprey,

(2.) Mature Form.

Petromyzon planeri,

Petromyzon sanguisuga,
Willcghey, Hist. Pisc. p. 107, tab. G. 3 fig. 1.

Artedi, Spec. Pisc. p. 9o, No. 3 .

Cuvier, R. An. ii. p. fo6; L1N., Syst Nal. i. p. 394; LACÉp., i. p. 26, pl. 2, fig. 1; Turton, Brit. Faun. p. I 1 o.

Pescant, Brit. Zool. iii. p. 107 , pl. x. fig. 3, ed. 1812.

Flem., Brit. An. p. i64; Jenrns' Man. p. 522 ; Yarkell, ii. p. 609; Parneld, Fish. Firth of Forth, Mem. Wern. Nat. Hist. Soc. vii. P. $4+7$. Couch, Fish. Brit. Isl. iv. p. 404.

Bloch, Fisch. Deutschl. iii. 1) 47; Lacér., i. 1) 30, pl. 3, fig. I; Jenyns' Man. P. 522 ; YARRell, ii. 1).607; Sienoln, Süsserwasserf. p. 375 (Kleines Neunauge); Couch, Fish. Brit. Isl. iv. P. 402, pl. 248 , fig. I ; GÜNTHER's Cat. viii. p. 504.

LACÊP., ii. P. IOI.

A LTHOUGH this little Lampern is too small to be of any commercial value, it is peculiarly interesting in a zoological point of view, because it is the species in which Professor Aug. Müller first demonstrated that the inclividuals of this genus undergo a meta- 
morphosis. The larval form, under the name of Ammocretss (Duméril, Cuv., R. An.), was long considered to be a species distinct from the Pitromyon flancri, until Müller (Müller's Archiv., 1856, p. 325) succeeded in tracing the development of Ammocates branchialis into P. plancri. It is probable, therefore, that not only the fishes of the genus Petromyzon, but also those of allied genera pass through a similar metamorphosis. In the larval form, the general shape of the body differs in no important respect from the mature individual; but the upper lip is semicircular, and the lower lip is very small; there are no teeth, and the mouth is furnished with numerous short membranous cirri. The eyes are very sinall, and are situated at the bottom of a small deep depression or groove. Ammocatcs branchialis is said to require three or four years for its complete development. The term Ammoccetes, or "sand-dweller," refers to the habits of this little larval form hiding itself in the sand or mud, for owing to the immature horse-shoe structure of the mouth, it is unable to adhere to stones or other submerged bodies, as in the case of the adult forms. The term branchialis was bestowed upon this fish by Linnæus, from a notion that it attached itself to the gills of fishes. As to size, it seldom exceeds six or seven inches in length, and is about as thick as a goose-quill. The fishermen use these fish as a bait in whiffng for Pollacks. "Buried in scattered companies in the soft soil," writes Couch, "it may be said to lead the life of the mole; and it is there it finds all it wants of food, in search of which, by taste or scent, it moves through its tracks as appetite or disposition prompts; and from observation it may be judged that, except in search of new feeding ground, it never willingly exposes itself to the dangers of a rapid stream, the strength of which it might scarcely be able to stem, or to the appetite of any prowling inhabitant of the river, from which its powers would not enable it to escape." Mr. Couch succeeded in keeping specimens of this larval form for months alive in stagnant water, with mud at the bottom, without injury to its health or activity. Dr. Plot, in his History of Oxfordshire, calls this Lampern the Pride of the Isis; the term prid, or pridc, is probably a form of the fuller word Lam-pren', from which by a process of phonetic decay it appears to have been derived.*.

In the mature form of this species the mouth is circular, and provided with numerous papillie forming a fringe,--hence called "The Fringe-lipped Lampern" by some authors, - the two dorsal fins are in close connexion, but separated by a deep notch; the dentition differs from that of $P$. fuviatilis merely in having the cusps less prominent and more obtuse. It grows to the length of eight or nine inches. This species is widely distributed, occurring in the rivers of Europe and North America. The spawning time is in March and April. This species was named by Bloch after Planer, a Professor at Erfurt. In colour $P$. branchialis hardly differs from $P$. fluviatilis. I find this species common in the brooks and streams of various parts of Shropshire. Excepting as bait or food for other fish it has no value.

* "Pride, a IIud Lamprey. Wist. 'Lumbrici are littell fyshes taken in small ryvers, whiche are lyke to lampurnes, but they be muche lesse, and somewhat yeolowe, and are called in Wilshyre prides,' (Elyote's Dictionarie, fol. Lond. 1599."-Halliwell's Arch. Dict. p. 645.) 



\section{A:PPENDix.}

\section{FRESHWATER FISHERIES ACT, 8Th. AUGUST, 1878.}

PE it enacted by the Queen's Most Excellent Majesty, by and with the advice and consent of the Lords Spiritual 13 and Temporal, and Commons, in this present Parliament assembled, and by the authority of the same, as follows:-

1. This Act may be cited as the Freshwater Fisheries Act, 1878 .

2. This Act shall, so far as is consistent with the tenour thereof, be real as one with the Salmon Fishery Acts, 186 I to 1876 .

3. This Act shall not extend to Scotland or Ireland, nor, except as regards sub-sections four and five of section eleven, and as regards scction twelve, to the counties of Norfolk and Suffolk, and the county of the city of Norwich.

4. This Act shall come into operation from and immediately after the thirty-first day of December one thousand eight hundred and seventy-eight.

5. Sections eight and nine of the Salmon Fishery Act, 186\%, (which rulate to fishing witl lights, spears, and other prohibited instruments, and to using roe as a bait,) and section sixty-four of the Salmon Fishery Act, 1865 , (which provides a close time for trout and char), shall, as amended by the subsequent Salmon Fishery Acts, apply to trout and char in all waters within the limits of this Act; and the term "salmon river," as used in section sixtyfour of the Salmon Fishery Act, 1865 , shall include any such water.

6. The provisions of the Salmon Fishery Acts, $186 j$ and 187 , which relate to the formation, alteration, combination, and dissolution of fishery districts, and to the appointment, qualification, proccedings, and pow'ers of conservators, shall extend and apply to all waters within the limits of this Act frequented by trout or char; and the term "salmon river" in the fourth and nineteenth sections of the Salmon Fishery Act, 1805 , and in the twenty-sixtl section of the Salmon Fishery Act, 1873 , shall mean any river frequented by salmon, trout, or char.

7. In any fishery district subject to a board of conservators, the conservators shall have power to issue licences for the day, week, season, or any part thereof, to all persons fishing for tront or char, and, in the event of the power being exercised in any fishery district, the provisions of the thirty-third, thirty-fourth, thirty-fifth, thirty-sixth, and thirty-seventh sections of the Salmon Fishery Act, I865, and of the twenty-first, twenty-second, twenty-fourth, and twenty-fifth sections of the Salmon Fishery Act, 1873 , (relative to licences,) shałl, with resject to such district, be construed as if the words "trout or char" were inserted throughout after the word "salmon."

Provided as follows:

(1.) A licence to fish for samon shall have effect as a licence to fish for trout and char.

(2.) The fee payable for a licence to fish for trout or char exclusively of sulmon in any listrict shall not exceed one third of the maximum amount chargeable for fishing for salmon under the lrovisions of the 2 ist. section of the Salmon Fishery Act, 1873 .

8. The provisions of the thirty-first section of the Salmon Fishery Act, 1865 , and of the thirty-sixtb, thirty-seventh, and thirty-eighth sections of the Salmon Fishery Act, 1873 , relative to the powers of water bailiffs, shall extend and apply to all waters within the limits of this Act, as if the words "salmon river," wherever they occur in such sections, included all waters frequented by salmon, trout, or char.

9. The provisions of the thirty-fourth section of the Salmon Fishery Act, 1861, which empower any justice of the peace upon information on oath to authorise the search of any premises, shall extend to all offences committed or alleged to have been committed under this Act, and that section shall be construed and have effect as if the word "salmon" included trout, char, and all freshwater fish. 
10. The provisions of the Salmon Fishery Act, 1876 , which empower a board of conservators to alter the period during which it shall be illegal to take or kill trout in any fishery district, shall extend to char, and the fourth section of that Act shall be construed and have effect as if the words "or char" followed the word "trout" in that section.

11. (1.) In this section the term "freshwater fish" includes all kinds of fish (other than pollan, trout, and char) which live in fresh water, except those kinds which migrate to or from the open sea:

(2.) The period between the fifteenth day of March and the fifteenth day of June, both inclusive, shall be a close season for freshwater fish:

(3.) If any person during this close season fishes for, catches, or attempts to catch or kill any freshwater fish in any river, lake, tributary, stream, or other water connected or communicating with such river, he shall, on summary conviction before two justices, be liable to a fine not exceeding forty shillings:

Nothing in this sub-section shall apply-

(II.) To the owner of any several or private fishery where trout, char, or grayling are specially preserved destroying within such fishery any freshwater fish other than grayling;

(b.) To any jerson angling in any several fishery with the leave of the owner of such fishery or in any public fishery under the jurisdiction of a board of conservators with the leave of said board;

(c.) To any person taking freshwater fish for scientific purposes;

(d.) To any person taking freshwater fish for use as bait:

it.) If any person during this close season buys, sells, or exposes for sale, or has in his possession for sale, any fresh-water fish, he shall, on summary conviction before two justices, be liable to a fine not exceeding forty shillings:

(5.) On a second or any subsequent conviction under this section the person convicted shall be liable to a finc not exceeding five pounds:

(6.) After every conviction under this section the person or persons convicted shall forfeit all fish so caught, bought, sold, exposed for sale, or in possession for sale, and shall be liable, at the discretion of the convicting justices, to the forfeiture of all instruments used in the taking of such fish:

(7.) A board of conservators appointed under the Salmon Fishery Acts, I861 to 1876 , or under this Act, may, as regards any or all kinds of freshwater fish, with the approval of the Secretary of State, exempt the whole or any part of their district from the operation of the first, second, and third sub-sections of this section. The exemptions shall be advertised in such manner as the Secretary of State shall direct:

(8.) The provisions of the Salmon Fishery Acts, i86 to 1876 , as to legal proceedings, offences, and penalties under those Acts, shall apply to legal proceedings, offences, and penalties under this section.

12. The Fisheries (Dynamite) Act, 1877 , which prohibits the use of dynamite or other explosise substance for the catching or destruction of fish in a public fishery, shall apply to the use of any such substance for the catching or destruction of fish in any water, whether public or private, within the limits of this Act.

13. So much of the Act of Parliament made and passed in the eighteenth year of the reign of King George the Third, chapter thirty-three, intituled "An Act for the better preservation of fish and regulating the fisheries in the River Severn and Verniew," as prohibits any person or persons in the months of June or July lasing, drawing, making use of, or fishing within the said rivers, or either of them, with any net the meshes whereof shall be under two inches and a half square by the standard, and not extended, or ten inches round, allowing to each mesh four knots, is hereby repealed. 
SLOB, OR TIDAL TROUT.

$\mathrm{T}$ HROUGH the kind exertions of Mr. William [Taynes, I have an opportunity of examining one of these fish. Owing to the severity of the weather few had as yet (February 25th., I879) made their appearance in the river, and Mr. Haynes was able to send me one specimen only. From an examination of a single individual $\mathrm{I}$ am not able to speak at all with certainty as to what these Slob Trout really are. The general appearance is that of a well-fed Common Trout (S. fario), from which, however, it seems to me to differ in a few structural characters. The maxillary in the specimen before me - a fish twelve inches in length, three in depth, and weighing nearly twelve ounces-is not so strong as that organ is in fario, nor does it extend perceptibly beyond the posterior orbit of the eye, as is the case in the Brown Trout. The tail is very decidedly forked, while in Trout of this size the caudal fin is almost always truncate; the sides and belly below the lateral line are more silvery, and appear to be covered with smaller and more deciduous scales than in fario. The dentition in the Slob Trout is rather feeble; the head of the vomer is without teeth; on the body of this bone there is a single series of teeth, fourteen or fifteen in number, arranged in a zigzag line; the dentition in fario is strong. In these particulars, therefore, the Slob Trout bears some resemblance to S. trutta, although in general appearance it is more like S. fario.

The following is a clescription of this specimen:-Total length twelve inches; greatest depth three inches; length of the head two inches and five eighths; maxillary one inch long, rather feeble, extending very slightly beyond the posterior orbit of the eye; prooperculum crescent-shaped, with an indistinct lower limb; suboperculum extending beyond the operculum; fins rather short. Dorsal fin pale brown, with pale purplish spots; adipose fin edged with red; the caudal fin forked, the lateral margins edged with red; fins without black and white outer edge; gill-cover with five or six purplish round spots; back and sides light purplish brown, with numerous large dark purple or red reticulated spots; several of these spots are surrounded with a whitish ring; there are some red or vermilion spots on the lateral line and below it; scales small and rather deciduous; belly and sides silvery, but in some lights this part is somewhat cream-coloured.

The specimen sent, which came in excellent condition, was amazingly fat; the stomach, œsophagus, and mouth were absolutely crammed with elvers, or young Eels, about two inches long; it had also been feeding on some crustacea allied to the fresh-water shrimp. The stomach and pyloric appendages were thickly spread over with fat. This specimen appears to be a sterile male. Mr. Haynes's account of the habits of the Tidal Trout will be found at page II4. They ascend the rivers with the flow of the tide, descending with the ebb; they are to be caught from January to May. In the summer they disappear, probably migrating to the sea, where they remain till the beginning of another year. Nothing is known about their spawning. In very cold weather in January and February they remain in the slob, and do not ascend with the tide.

I am inclined to believe that these Tidal Trout are hybrids between the S. fario and $S$. trutta, both of which species they appear to resemble in some particulars. It may be that the sexual organs do not develope; consequently there is no spawning time. Did they spawn in the rivers, such an occurrence would have been noticed by so patient and painstaking an observer as Mr. Haynes. Is it possible that they spawn in the salt water of the sea? Such a phenomenon would be an exception to what is known to occur in the Sulmonida. Moreover, did these fish spawn in the sea, say in November or December, could they possibly appear in the rivers, as early as January, in such splendid condition as they are known to show at that time? They could not have "mended" themselves in so short a time. 
In general appearance the Slob Trout looks like the Common Trout, as I have said, but in certain structural characters it reminds one of the Salmon Trout. In its migratory habits it more closely resembles this latter fish, although the Common Trout is known occasionally to adopt migratory habits, and to descend to the sea.

The word slob, of which slab and slop are only other forms, denotes wet and loose mud, such as is usually abundant at the estuaries of rivers. The Trout descend with the tide to the slob, where they remain till the return of the tide.

TITLES OF WORKS

AND EDITIONS QUOTED IN THIS VOLUME.

Aristotelis, De Animalibus Historix, Libri x. ed. Schneider, 18 г.

Elian, De Animalium Naturæ, ed. Jacobs, 2 vols. 8vo., Jenæ $18,32$.

Plinius (C. Secundus) Historia Naturalis, Lugd. Batav. et Roterod. apud Hackiós 1669.

Athenæus, Deipnosophistæ (Lib. vii.) ed. Dindorf, Leipsic 1827 .

Oppianus, Halieutica, ed. Schneider, Argentorati 1776.

Ausonius, Id. x. Carmen de Mosella; Corpus Poet. Latin.

Bellonius (Petrus) De Aquatilibus, Paris ${ }_{553}$.

Rondeletius, Universa Aquatilium Historix pars altera (de Piscibus, Lib. iv.-vii.), ${ }_{5} 60$.

Aldrovandus, De Piscibus, $16{ }_{3} 8$.

Willughby (Franciscus) De Historia Piscium libri quatuor, recognovit Johannes Ray, 1686.

Artedi (Petri) Ichthyologia sive opera omnia de Piscibus, recognovit Carolus Linnæus, $173^{8}$.

Barrington on the Gillaroo Trout, also Hunter and Watson in Philosophical Transactions for $177+$.

Linnæus (Carolus) Systema Naturæ, Holmiæ, ed. 1766.

Pennant, British Zoology, 4to., Warrington, printed by William Eyres, + vols., 1776-1777; and 8vo., + vols., ed. isı12.

Walton (Izaak) and Cotton, Complete Angler, ed. Sir J. Hawlins, 1760.

Bloch, Naturgeschichte der Fische Deutschlands, 4to. ed. Berlin 1782.

Lacépède, Histoirc des Poissons, Paris $1798-1803$, 4to.

Cuvicr, Le Règne Animal, 8vo., Paris 1800-i 805 .

Donovan (Edw.) The Natural History of British Fishes, 5 vols. 8vo., London 1802-1808.

Turton, The British Fauna, Swansea 1807.

Fleming (John, D.D.) History of British Animals, 2nd. ed., London $18+2$.

Cuvier et Valenciennes, Histoire Naturelle des Poissons, Paris 1828.

Richardson (Sir John) Fauna Boreali-Americana, Part iii., London, fto., $1 \$_{3} 6$.

Parnell, The Natural History of the Fishes of the Firtl of Forth, in vol. vii. of the Memoirs of the Wernerian Natural History Society, Edinburgh 1838 .

Yarrcll (William) A History of British Fishes, 2nd. edition, London, Van Voorst, $18+1$.

Jenyns (Rev. Leonard) A Nanual of British Vertebrate Animals, Cambridge, 1835.

Jardine (Sir William) and Selby, Edinburgh New Philosophical Journal for 1835 .

Jardine (Sir William) Illustrations of Scotch Salmonidx, folio.

Owen (R.) Descriptive Catalogue of the Physiological Series contained in the Collection of the Royal College of Surgeons, vol. i. Fishes, London, tto., 1853 .

Owen (R.) On the Anatomy of Tertebrates, vol. i. Fishes, London 1866.

Gaimard (P.) Toyage en Islande et en Grönland, cxícuté pendant les années 1835 et 1836 sur la Corvette 'I.a Recherche,' Paris 1851 .

Davy (Sir Humphry) Salmonia, London, J. Murray, i 869.

Davy (Dr. John) Physiological Researches, London 1863 .

Couch, Fishes of the British Isles, 4 vols. 8vo., $1862-1866_{5}$.

Siebold, Die Süsserwasscrfische von Mlittel-Luropa, Leipzig $186_{3}$.

Thompson (William) The Natural History of Ireland, + vols., vol. iv., 1856 , 8 vo.

Günther's Catalogue of the Fishes in the British Museum, 8vo., 8 vols., London 1859-1870.

Buckland (F.) Familiar History of British Fishcs, 8ro., S. P. C. K. I 873 . 
ANDEX.

Azurine

Abramis

Abramis blicca .

Abramis brama

Acerina cernua.

Acipenser sturio

Alburnus lucidus

Anmocæetes branchialis

Anguilla latirostris

Anguilla vulgaris

Dace .

1)

Dobule . . . . . +4

Barbel

Bleak

Bream, Common

Bream, Pomeranian

Bream, White

Bull-head

Bull-Trout

Burbot

Barbus vulgaris

Carp, Common

Carp, Crucian .

Carp, Golden

Carp, Prussian .

Charr, Family of

Charr, Alpine.

Charr, Cole's

Charr, Gray's

Charr, Loch Killin.

Charr, Welsh

Charr, Windermere .

Chub .

Carassius auratus

Carassius vulgaris

Carassius vulgaris var. gibelio

Clupea alosa

Clupea finta

Cobitis txnia

Coregonus clupeoides

Coregonus pollan

Coregonus vandesius

Cottus gobio

C.jprinus carpio

Eels, Family of, etc. . . . 173

Eel, Blunt-nosed . . . . 188

Eel, Sharp-nosed . . . 187

Ecl-pout . . . . . 165

Esox lucius . . . . . $\quad 73$

G

Galway Sea Trout . . . . 105

Gillaroo Trout . . . . .

Graining . $\quad$. $\quad$. $\quad$. $\quad$. +3

Grayling . . . . . $1+9$

Gudgeon . . . . . . 30

Gwyniad . . . . 153

Gasterosteus aculcatus . . . II

Gasterosteus brachycentrus . . I4

Gasterosteus gymnurus . . . I I

Gasterosteus pungitius . . .

Gasterosteus semiarmatus . . . $\quad 13$

Gasterosteus semiloricatus . . . I

Gasterosteus spinulosus . . . . 14

Gasterosteus trachurus . . .

Gobio fluviatilis . . . $\quad 30$

Lampern, Planer's . . . . . 196

Lampern, River . . . . . 195

Lampreys . . . . 191

Lamprey, Sea . . . . . . 193

Loach, Common . . . . $\quad 65$

Loach, Spined . . . . . . 66

Leuciscus cephalus . $\quad$. $\quad 37$

Leuciscus erythrophthalmus . . $4+5$

Leuciscus phoxinus . $\quad$. $\quad 63$

Leuciscus rutilus . . .

Leuciscus vulgaris . $\quad$. $\quad$. $+t^{1}$

Lota vulgaris . . . $\quad$ I 65

Miller's-thumb . . . . 7

Minnow $\cdot$. $\quad . \quad$.

Nemachilus barbatulus . . $\quad 65$ 
PAGE

$16 \mathrm{I}$

Parr

Perch

Pike

Pollan

Pope

Powan

Perca fluviatilis

Petromyzontidæ

Petromyzon branchialis

Petromyzon fluviatilis

Petromyzon marinus

Red-eye

Roach

Rudd

Ruffe

\section{Salmonidæ}

\section{Salmon}

Salmon-Trout

Salmon-Trout, Galway

Salmon, Short-eared

Salmon, Silvery

Sea-Trout, (see Salmon Trout)

\section{Sewen}

Shad, Allis

Shad, Twaite

Smelt, or Sparling .

Sticklebacks

Sturgeon .
. $16 \mathrm{I}$

$\mathrm{P}$

I

73

157

5

I 59

I

I 91

196

I 95

193

R

45

33

45

5

S

79

83

93

105

107

108

97

69

$7 \mathrm{I}$

161

I $1-1+$
PAGE

Salmo alpinus . . . . . $\quad$ I 43

Salmo argenteus $\quad$. $\quad . \quad . \quad . \quad 108$

Salmo brachypoma. . . . $\quad$. 107

Salmo cambricus $\quad$. $\quad$. $\quad 97$

Salmo colii . . . . $\quad 138$

Salmo eriox . . . . . 99

Salmo fario . . . .

Salmo ferox . . . . . 129

Salmo gallivensis . . . . 105

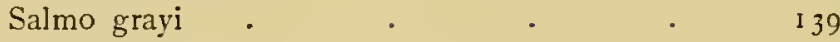

Salmo killinensis . . . . . $\mathrm{I}+5$

Salmo levenensis _ . . $\quad 123$

Salmo nigripinnis . . . $\quad$. 119

Salmo orcadensis . $\quad$. 121

Salmo perisii . . . . $\quad$ I 1

Salmo salar . . . . . $\quad 8_{3}$

Salmo stomachicus . . . . 125

Salmo trutta.$\quad$. $\quad$. 93

Salmo willughbii . . . . $\quad$ I $\quad$ I 35

Tench, Common . . . . . . 49

Tench, Golden . . . . . . 51

Torgoch . . . . $1+1$

Trout, Black-finned . . . II

Trout, Common . . 111

Trout, Gillaroo . . . . 125

Trout, Great Lake . . . . 129

Trout, Lochleven . . . 123

Trout, Loch Stennis . . I II

Trout, Slob or Tidal (var.) . . 114, 201

Thymallus vulgaris. . . I . I

Tinca vulgaris and var. . . 49,5 I 


$1+\sqrt{6}$

MS.

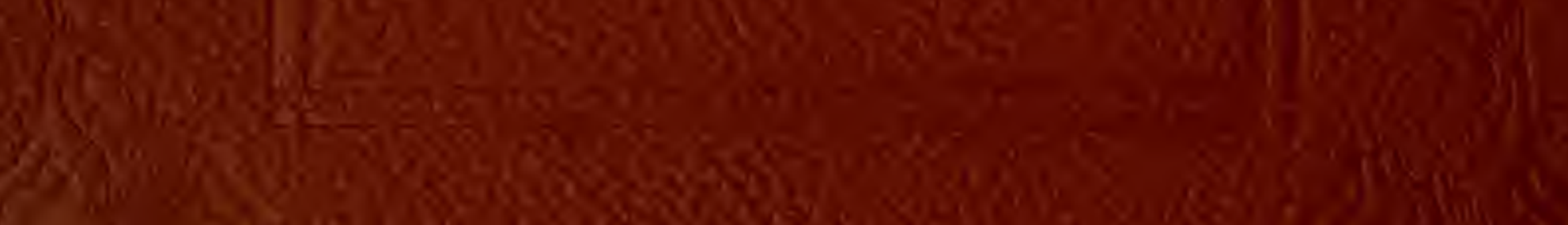

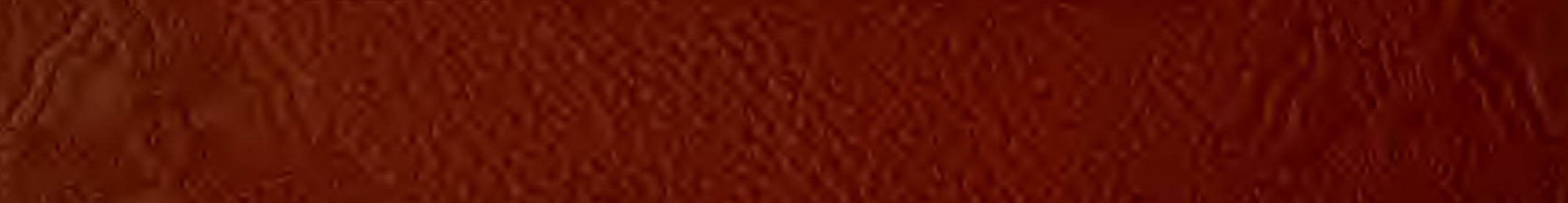

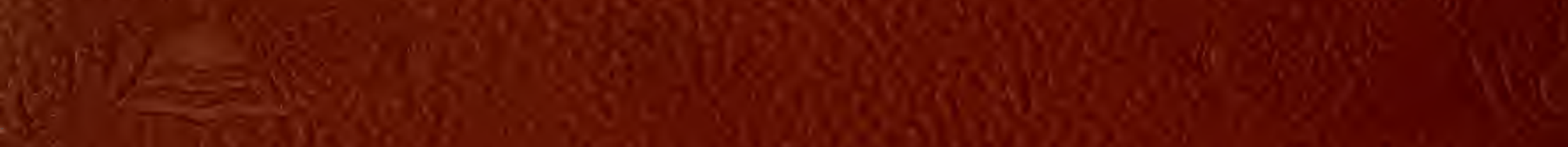
Lich b. 